
(1)

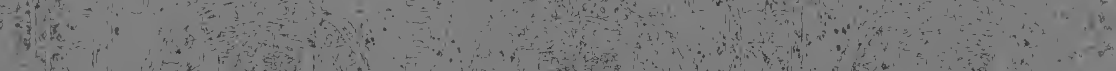

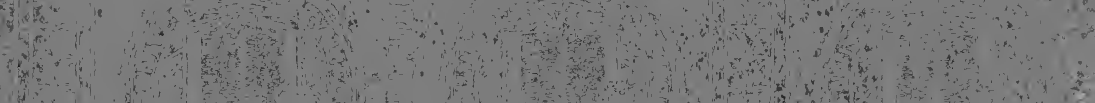
and

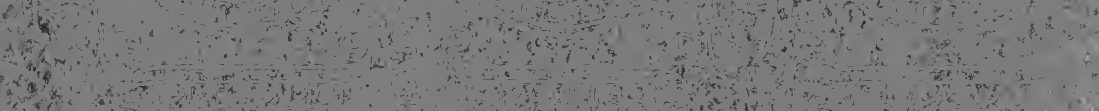

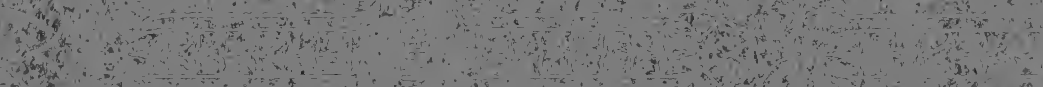

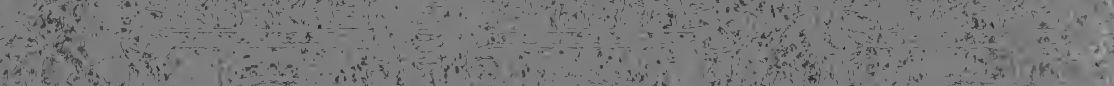

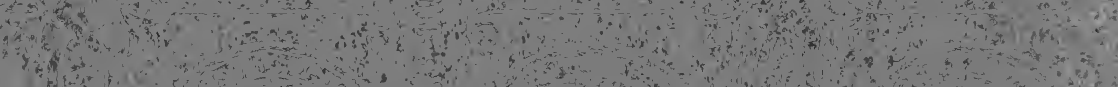
ter P.

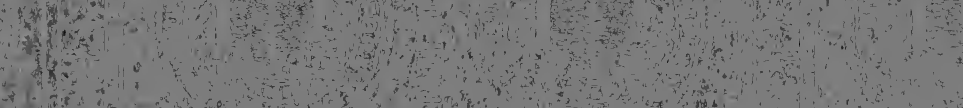

(1)

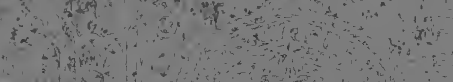

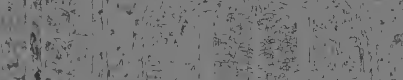

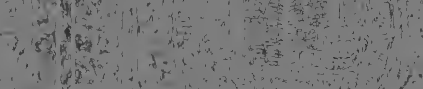

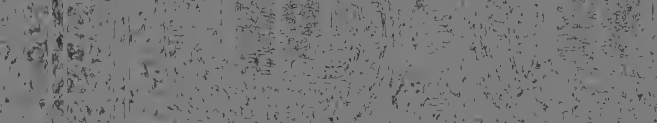

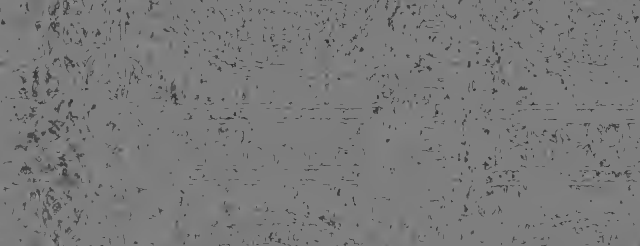

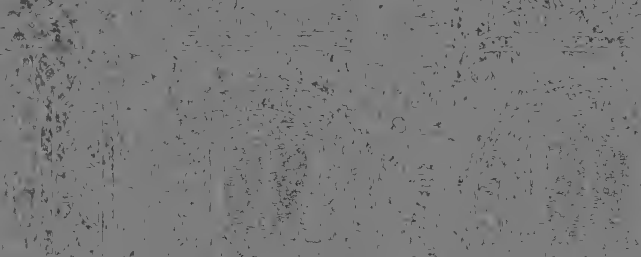

$\lim _{i \rightarrow 1}$

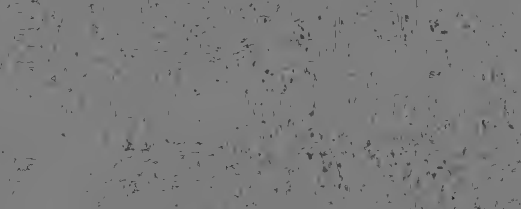




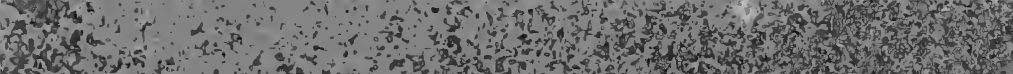

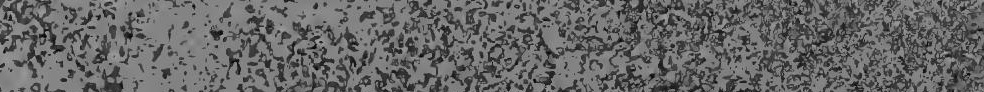

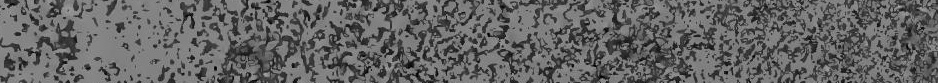

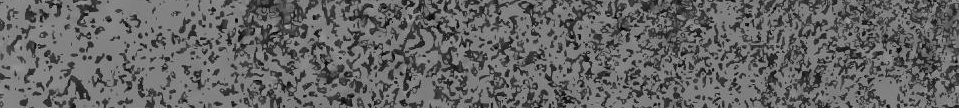

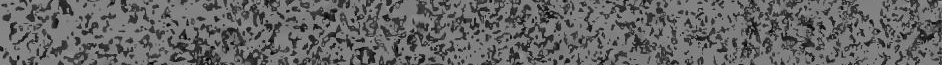

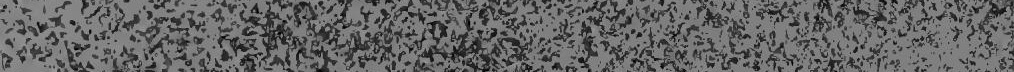

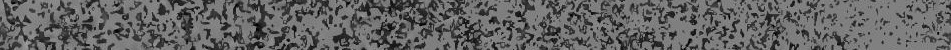

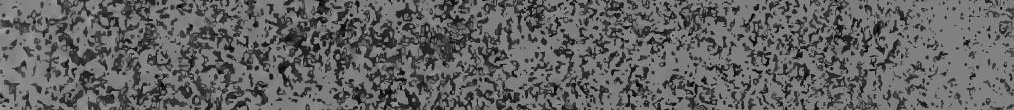

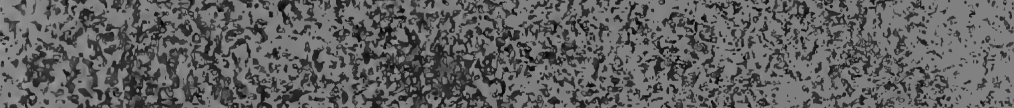

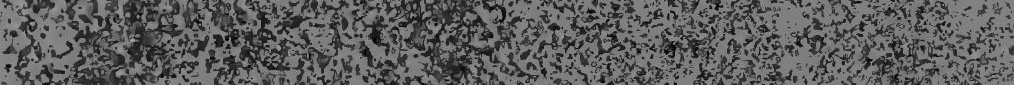
- 5 1).

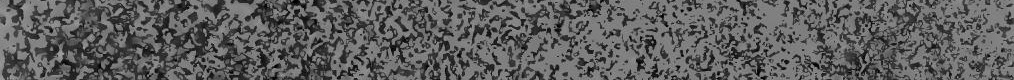

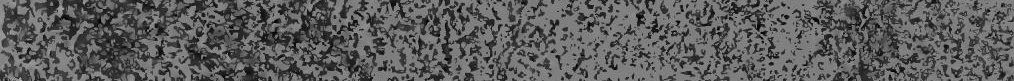

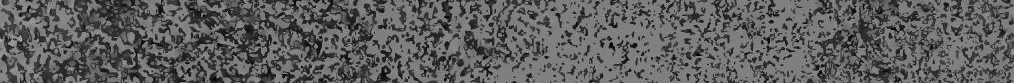

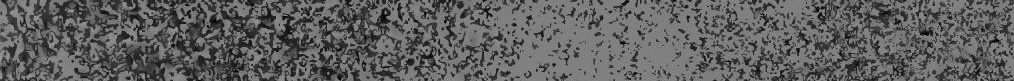
15.

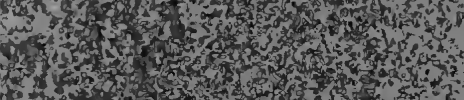

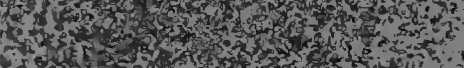

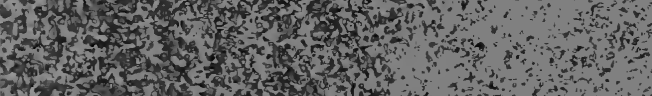

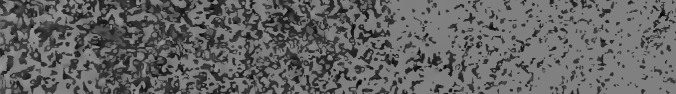

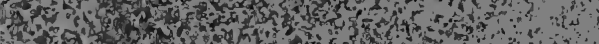

9.

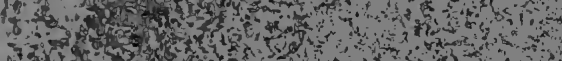

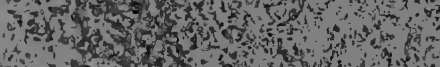

1.

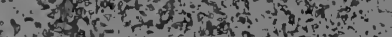

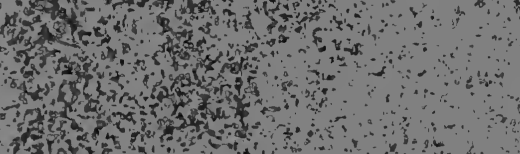

istat?

sitis

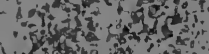

The

and

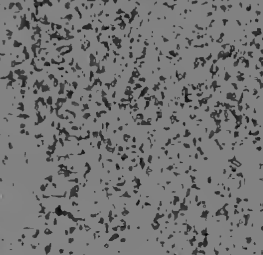

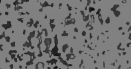

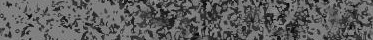$$
\text { on }
$$

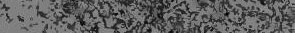

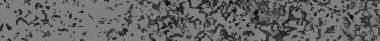

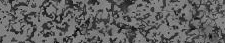

2.7. ros to to

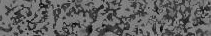

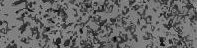

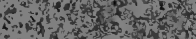

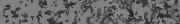

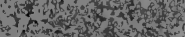

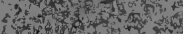

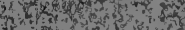

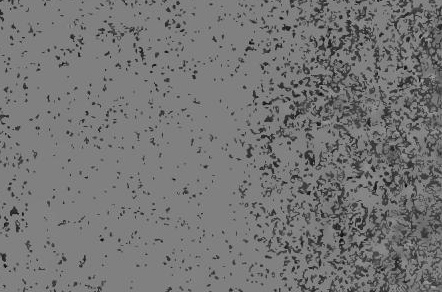
and 3

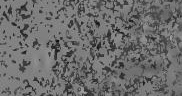

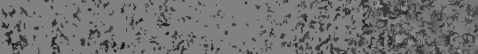
is:

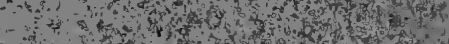



Digitized by the Internet Archive in 2007 with funding from Microsoft Corporation 
EARLY

PROSE AND POETICAL WORKS

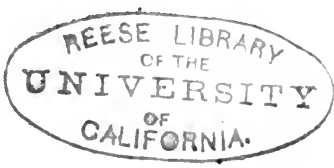





\title{
EARLY
}

\section{PROSE AND POETICAL}

\section{WORKS}

\author{
$\mathrm{OF}$ \\ J O H N T A Y L O R \\ The Water Poet \\ (1580-1653)
}

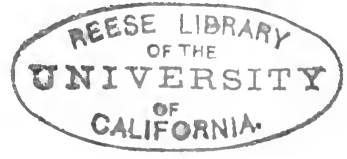

LONDON: HAMILTON, ADAMS \& CO GLASGOW : THOMAS D. MORISON 
66658 


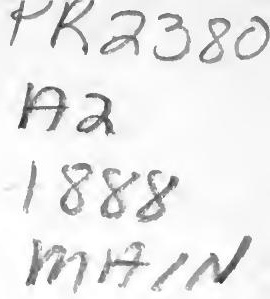

EDITORIAL NOTE:

THE greater part of the reading public have heard many times of John Taylor, The Water Poet, and probably know a good deal about him. But it is pretty safe to say that very few comparatively have ever seen any of his writings. Taylor's literary productions are all scarce and difficult to get. In these pages, for the first time, are any of his works placed within the reach of readers of very moderate means; and it may be appropriate to accompany them with a few biographical particulars regarding their singular author.

John Taylor was born on the 24th August 1580, at Gloucester. Little is known regarding his parentage, boyish days, and education, and for what little is known in these respects, we are chiefly indebted to stray remarks scattered throughout his numerous writings. That Taylor's parents belonged to the masses wo may rest assured, but are not informed by what trade they earned a livelihood. We infer however, that they had been sufficiently well off, to keep their son at school for some years, as in his writings, Taylor refers to school-days and school boy poetical compositions. He also narrates an amusing anecdote regarding his schoolmaster, which has often been told, and may be repeated here. The poor man was in need of a cow, and on the occasion of his going to the market in order to purchase one, some of the neighbours played him rather an amusing trick. It would appear that the schoolmaster was extremely short-sighted, and in other respects as well, was better suited to deal with books than to buy or sell cattle. This the neighbours fully aware of, with that love of innocent mischief which has not been confined to any age of the world's history, sold the poor man a bull in place of a cow, and which animal the hero of the rod drove contentedly home. Remaining entirely ignorant of the trick that had been played off upon him, until desiring to taste the milk of his new purchase, he requested the maid to milk the animal, and the amusing scene which followed may be readily imagined.

At an early age, young Taylor was taken from school, and apprenticed to a Thames waterman, or what would now be termed a ferryman, only the calling was not confinod simply to carrying passengers 
across, but also up and down the river. At this period coaches were not in use, so that a boat or barge was the most convenient means of transit to or from places on or near the banks of the river. The calling was one of great responsibility, and was regarded as both honourable and profitable, and was pursued only in accordance with strict government rules. The number of boatmen engaged in this way at that time was very large, and has been placed as high as forty thousand, which, however, is no doubt an over-statement, but serves all the same to show how very considerable the total must have been. Taylor's apprenticeship had not been of long duration, as we find that he was serving in the royal navy in 1596, and was at the taking of Cadiz in that year, under the Earl of Essex. Being born in 1580, the young poet could not be more than sixteen years of age on entering the navy. As accounting for the early change, from being an apprentice to a Thames waterman, to becoming a manof-war's man, it has been surmised that probably himself had no say in the matter, but that it was simply brought about by unavoidable circumstances. During this war, as on the occasion of all others, it was customary to keep the vessels of the royal navy efficiently manned by means of impressment; and in such instances watermen and their apprentices were naturally among the first and best victims. The requirements of the Admiralty for this attack on the Spanish coast were so great that orders were issued, we learn, for the impressment of no fewer than a thousand additional men. And the suggestion that Taylor formed one of the new recruits is not at all unlikely. In any case, we have it on his own authority, that he served on board one of the vessels of that particular fleet. We also learn from his own writings that he made sixteen voyages in the Queen's ships, all of which would be prior to 1603, the year of Queen Elizabeth's death.

On retiring from active service in the Queen's ships, Taylor appears to have fully adopted his former calling, of a Thames waterman. In those days it was a thriving trade, and a very natural one for a sailor. Likewise having served in the royal navy he would be entitled by law to a waterman's licence without fulfilling the usual requirements regarding an apprenticeship. For some years at this time the calling, it would appear, was quite a lucrative one, and no doubt Taylor would get his full share of the benefit going. But after a while a change seems to have come over the scene from several causes. The continued peace under King James I. permitted of the 
Admiralty discharging several thousand men from the royal navy, many of whom took to the waterman's calling to earn a livelihood, thus increasing competition and reducing the profits to each. Likewise coaches got to be increasingly used, the effect of which also tended to lessen the watermen's receipts. Another misfortune for the watermen was the removal of the theatres from the Surrey side of the river to the Middlesex one, where they were placed far from the Thames, and attracted some thousands of persons away, who formerly spent some of their money on the water. This latter misfortune proved so serious, that the watermen actually petitioned King James, not to allow the erection of any playhouse on the Middlesex side of the river. In ventilating this supposed grievance, the watermen found a clecer representative and advocate in the person of their brother-in-trade, John Taylor, who wrote at this time The True Cause of the Watermen's Suit, published in 1613. Of course it was unreasonable in the boatmen, desiring for their own benefit, that all who wished to attend the playhouse, should be burdened with the trouble and expense of crossing and recrossing the river in all sorts of weather. And naturally, such was the view that players, people, and sovereign, took of the question.

Little appears to be known regarding Taylor's marriage or his wife. But we should imagine that he probably entered into the inarried state a considerable while before entering upon the career of an author, which latter step he took at the age of thirty-two,- the poet's first venture of that description bearing date 1612. The Water Poet's experience of matrimony seems to have been pretty much that of the common lot, namely, rather a mixed quantity, but on the whole satisfactory and desirable. When an old man he thus describes his practical acquaintanceship with that sacred state :-

"I have a wife which I was wont to praise, But that was in my younger wooing days; And though she's neither shrew, nor sheep, I vow With justice I cannot dispraise her now. She hath an instrument that's ever strung To exercise my patience on-her tongue. But past all question, and beyond all doubt, She'll ne'er infect my forehead with the gout. A married man, some say, hath two day's gladness, And all his life else, is a lingering sadness ; The one day's mirth is, when he first is married, The other's, when his wife's to burying carried. 
One I have had, should I the t'other see,

It could not be a day of mirth to me.

For I, as many have, when I did woo,

Myself in tying fast, did not undo;

By I have, by long experience found

I had been undone, had I not been bound.

I have my bonds of marriage long enjoyed,

And do not wish my obligation void."

Scarcely anything is known regarding the poet's worthy help-mate further than that she survived him for the space of five years. And for that length of time carried on, in her own name, the public-house of which Taylor became proprietor some time before his decease.

Taylor's first literary venture was published in 1612. It appears to have been a success, as a second edition was issued two years afterwards-1614. The book, or rather pamphlet, bore an odd title, and this feature in the work was considerably increased in the second impression; as thus amended the title ran as follows: "Taylor's Water-Worke, or the Sculler's Travels from Tyber to Thames : With his boat laden with a hotch-potch, or Gallimawfrey of Sonnets, Satyrs, and Epigrams. With an Inkhorne Disputation betwixt a Lawyer and a Poet : and a quarterne of new catcht Epigrams, caught last Fishing-tide ; Together with an addition of Pastorall Equivocques, or the complaint of a Shepheard; dedicated to neither Monarch nor Miser, Kaiser nor Caitiff, Palatine nor Plebian, but to the great Mounsier Multitude, alias All, or every one." The foregoing formidable looking production, was followed by an immense succession of books and pamphlets on all sorts of subjects. This extraordinary flow of literature came from Taylor's pen at the average rate of over three works per annum, and the stream only ended with the author's decease in 1653. The manner in which he published the books was, to print them at his own cost, get as many sold as possible, make presents of a good many more to distinguished persons, and hope therefrom for a return in cash. That the return in cash very often came far short of his hopes is forcibly depicted in the clever and amusing work entitled, "A Kicksey-Winsey or Lerry-Come-Twang," which production will be found in the following pages. This is not a high style of publication, but the times were not fastidious, and there was nothing especially strange in him adopting the method that was in use among others. And it had the great advantage to the author, of bringing him under the notice of almost all the distinguished people of the period, many of whom 
otherwise, especially those who had little taste for reading, might have remained comparatively ignorant of this remarkable man. Of the fact that Taylor was well known during his life, in both England and Scotland, we find ample proof in the volumes of travels that he issued. In these particular volumes, numerous instances occur of cordial hospitality extended to the author, on the part of all sections of society, almost wherever he went-noblemen, literary men, municipal authorities, merchants, and others. That a portion of this attention on their part, was the result of having been presented from time to time by the author, with some of his writings, we cannot doubt. Both King James I. and Charles I. appear to have been among his patrons, and it is probable that on some occasions he may have been admitted to their presence.

That extraordinary bibliographer, Southey, has done a good deal to bring Taylor's name and writings under the notice of the reading public. In editing the poems of John Jones, an old servant, he prefaced the book with an account of uneducated or self-educated poets and writers, and the account of Taylor is the most interesting portion of the volume. Southey says of him : "If he had been in a higher grade of society, bred to some regular profession, he would probably have been a much less distinguished person in his generation. No spoon could have filled his mouth so well as the wooden one to which he was born. His way of life was best suited to his character, nor could any regular education so fully have brought out that sort of talent which he possessed." This opinion of the great poet and bibliographer may be true so far as it relates to the amount of distinction that was conferred on Taylor by his own generation. But the want of early privileges in the matter of education and culture, cannot tend to make an author's writings live throughout succeeding generations. It is interesting to contemplate what standing the writings of The Water Poet might have attained, had their author been differently situated in such respects. Had he, instead of taking part in England's battles on board the ships of the royal navy; between the ages of fifteen and twenty-three, been walking in the paths of education and culture, we may rest assured that a very pronounced effect throughout the whole of his writings would have been the result. And, that these influences would have been entirely in the right direction, we cannot doubt. Taylor is one of the most voluminous writers of any age. The majority of his writings are overflowing with felicitous expressions and ready wit. 
He was a keen observer of character, custom, and incident. But he wrote far too much and studied far too little. Had he exercised his mental powers less in the manner that he did exercise them, and more after the manner of his four great contemporaries, Shakespeare, Beaumont, Fletcher, and Benjamin Jonson. Then, probably his writings might have lived as theirs have, though it might have been in a totally different walk. In Taylor's writings there is abundance of amusement, their value, however, lies chiefly in the vivid and interesting description of English and Scottish life and custom of the period, which is to be found therein.

The Water Poet appears to have been exceeding fond of travel and adventure. His life was full of them. The adventures helped his books, and the books helped him through the adventures. In 1616 he visited the continent, and gave the result of his journey the following year in a volume bearing the annexed title, "Taylor's Travels in Germany : or, Three weeks, three days, and three hours Observations and Travels." The author was a keen observer, as we have mentioned, and there is much in this volume of interest. In 1618 he undertook to travel on foot from London to Edinburgh, not carrying any money to or from, neither begging, borrowing, or asking meat, drink, or lodging, and published an account of it in verse aud prose, entitled "The Penniless Pilgrimage : or, The Moneyless Perambulation of John Taylor." To many, this will prove the most interesting of The Water Poet's writings, as it is particularly rich in descriptive material. The author went far beyond Edinburgh, penetrating even to the wilds of Braemar, and there became the guest of the Earl of Mar, at a hunting encampment among the hills. Taylor describes all he saw and experienced, and liked the sport so much that he made two sonnets upon it. After the hunt broke up he was entertained by the Marquis of Huntly and other noblemen, and then returned to Edinburgh, where he met Ben Jonson, who was at that time on a visit to Scotland in order to see Drummond the historian and poet. Shortly after this, Taylor fulfilled a wagering journey all the way to Bohemia, and at Prague partook of the Queen's bounty; he also had her eldest son in his arms, and brought away the infant's shoes as a memento of his visit. In 1622 another strange journey was undertaken, namely, "A Very Merry-WherryFerry Voyage : or, York for my Money : Sometimes Perilous and sometimes Quarrelous : Performed with a pair of oars by Sea from London," a very amusing work. On his way thither, being 
compelled by stress of weather to land at Cromer, the whole town became alarmed. $\mathrm{He}$ and his men were mistaken for pirates, and were put under custody, and guards set over the wherry. In the following year he made a somewhat similar voyage, "A New Discovery by sea with a wherry from London to Salisbury," and which he describes as the worst, or the best, for toil, travel, or danger, that he had yet made. A number of other such journeys were made to various parts, each one resulting in a book with an odd title. And notwithstanding all these peregrinations, there was over and above a continual flow of other literary productions coming from his pen on all sorts of subjects, some of them in verse, others again being in prose.

The year 1630 must have been a notable and rather an anxious time for the poet. As in that year was published in one very large folio volume, a collected edition of all his writings up to that period. The whole representing over six hundred closely printed, donble column pages, and iucluding no fewer than sixty-three separate works. Such being the number, that the writings of The Water Poet had accumulated to, in the course of the eighteen years since he first took up the pen. The undertaking was so great that in order to get finished without delay, it had to be divided among four different printers, this resulting naturally in a good deal of confusion and mismanagement, of which the volume bears abundant traces. It was certainly a bold venture to publish such an immense volume, and must have cost a very large sum of money. This volume is now extremely scarce, and fetches from fifteen to twenty pounds according to condition. About one-third of the volume is prose and the other two-thirds consist of verse.

Having published a collected edition of his works, one might have supposed that possibly The Water Poet contemplated the cessation of such work, all the more so that in total volume or amount, they exceeded the writings of any of his four contemporaries already named. But it would appear that he had no idea of thus closing this, to him, delightful outlet for his mental activity and energy. The stream of new works from his pen continued as great as ever. He also continued to indulge in sundry journeyings both by sea and land.

Long prior to his decease, Taylor abandoned the calling of waterman, and, instead, settled down to the trade of licenced victualler. His tavern he christened by the name of the Poet's Head, it was 
situated in Phœnix Alley, Long Acre, Covent Garden. This change, no doubt, suited a person of the mature years that he had now arrived at, much better. And it afforded to him the additional advantage of a convenient publishing office for his now very numerous books and pamphlets. All the later literary productions have, as publisher, his own name at the foregoing address. John Taylor, The Water Poet, died in 1653, and was buried on the 5th of December in the churchyard of St. Martin's-in-the-Fields-the parish in which his combined dwelling-house, tavern, and publishing depot, was situated.

In the volume published in 1630 we of course find the complete writings up to that year, and these, as already mentioned, amounted to sixty-three in number. The exact number of Taylor's writings after that date will probably never be fully known. That they at least exceed seventy additional there can be no doubt, as printed lists of the titles of more than that number have been given by bibliographers. But since the time at which the latest of these lists was compiled, a number of fresh discoveries have been made, and which of course are not included. And in the circumstances, we cannot doubt, that fresh discoveries will continue to be made for many years to come. The reason of the extreme rarity is, that most of the works were simply pamphlets without any protecting boards; and pamphlets, as a rule, get tossed aside and destroyed pretty much as in the case of newspapers. Concerning these various pamphlets, they are so much prized and competed for, by book collectors, that when they do turn up, they can seldom be had for less than several pounds each. Thus entirely putting them out of the reach of the ordinary reader. Many years ago a reprint in three volumes folio, of the 1630 collection was brought out by one of the literary societies. But extremely few copies seem to have been printed, and it appears to be as scarce, or even more so, than the original brought out by the author. Whether an attempt will ever be made to publish as complete an edition, as present knowledge and circumstances will permit of, remains to be seen. The undertaking, though highly desirable, would certainly prove one of stupendous magnitude and expense. 


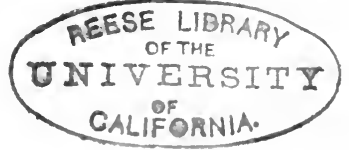 \\ C O N T E N T S.}

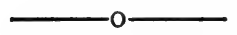

The Penniless Pilgrimage, or the Moneyless Perambulation of John Taylor, alias the King's Majesty's Water Poet, - 17-60

A Kicksey-Winsey, or a Lerry ComeTwang, wherein John Taylor hath satyrically suited Eight Hundred of his bad debtors that will not pay him for his re-. turn of his journey from Scotland, - 61- 78

An Armada, or Navy of 103 Ships and other Vessels, which have the art to Sail by Land as well as by Sea. Morally rigged, manned, munitioned, appointed, set forth, and victualled with thirty-two sorts of ling, and with other Provisions of Fish and Flesh, 
The Great Eater of Kent, or Part of the admirable Teeth and Stomach Exploits of Nicholas Wood, of Harrisoon, in the County of Kent. His excessive manner of eating without manners in strange and true manner described, -

Three Weeks, Three Days, and Three Hours Observations and Travels from London to Hamburg, amongst Jews and Gentiles, with Descriptions of Towns and Towers, Castles and Citadels; Artificial Gallowses, and Natural Hangmen. And dedicated for the present, to the absent Odcombian Knight Errant, Sir Thomas Coriat, Great Britain's Error and the World's Mirror,

A Very Merry Wherry-Ferry Voyage, or York for my Money. Sometimes Perilous and sometimes Quarrelous, Performed with a pair of oars by sea from London, by John Taylor and Job Yennell, and written by J. $T$. ,
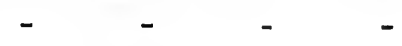

159-182

Jack a Lent: His Beginning and Entertainment, with the mad pranks of his gentleman 
usher Shrove-Tuesday that goes before him and his footman Hunger attending, - - 183-199

The True Cause of the Watermen's Suit concerning Players, and the Reasons that their Playing on London Side is their extreme hindrances, with a relation how far that suit was proceeded in, and the occasion that it was not effected, - $\quad$ - $\quad$ - $\quad 201-212$

A New Discovery by Sea with a Wherry from London to Salisbury, - $\quad$ - 213-241

The Unnatural Father, or a Cruel Murder committed by one John Rouse of the town of Ewell, ten miles from London, in County of Surrey, upon Two of his own Children,

The Old, Old, very Old Man, or the Age and long Life of Thomas Parr, the son of John Parr of Winnington, in the Parish of Alberbury, in the Salopp. Who was born in the reign of King Edward Fourth, being aged 152 years and odd months. His Manner of Life and Conversation in so long a Pilgrimage. His marriages, and his 
bringing up to London about the end of September last 1635. Whereunto is added a Postscript showing the many remarkable incidents that happened in the Life of the

Old Man, -
Part of this Summer's Travels, or News from Hell, Hull, and Halifax, from York, Linne, Leicester, Chester, Coventry, Lichfield, Nottingham, \&c. With many pleas-
ant passages worthy your observation and field, Nottingham, \&c. With many pleas-
ant passages worthy your observation and reading,

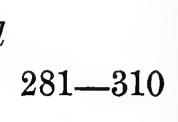

Mad Fashions, Odd Fashions, All Out of Fashions, or the Emblems of these Distracted Times, - $\quad$ - $\quad$ - $\quad$ - 311-318. 


\section{THE PENNILESS PILGRIMAGE}

OR

THE MONEYLESS PERAMBULATION

OF

JOHN TAYLOR

Alias the King's Majesty's Water Poet.

How he travelled on foot from London to Edinburgh, in Scotland, not carrying any money to or from, neither begging, borrowing, nor asking meat, drink, or lodging.

With his description of his entertainment in all places of his journey. And a true report of the unmatchable hunting on the Braes of Mar and Badenoch, in Scotland.

With some other observations, some serious and worthy of memory, and some merry and not hurtful to be remembered.

Lastly, that which is rare in a traveller, all is true. 


\section{DEDICATION.}

-

To

The truly noble and Right Honourable Lord George, Marquis of Buckingham, Viscount Villiers, Baron of Whaddon, Justice in Eyre of all his Majesty's Forests, Parks, and Chases beyond Trent, Master of the Horse to his Majesty, and one of the Gentlemen of his Highness's Royal Bedchamber, Knight of the most noble Order of the Garter, and one of his Majesty's most honourable Privy Council of both the Kingdoms of England and Scotland.

RIGHT Honourable and worthy honoured Lord, as in my travels, I was entertained, welcomed, and relieved by many honourable lords, worshipful knights, esquires, gentlemen, and others, both in England and Scotland, so now your Lordship's inclination hath incited or invited my poor muse to shelter herself under the shadow of your honourable patronage, not that there is any worth at all in my sterile invention, but in all humility I acknowledge that it is only your Lordship's acceptance that is able to make this nothing something, and withal engage me ever.

\section{TO ALL MY LOVING ADVENTURERS, BY WHAT NAME OR TITLE SOEVER, MY GENERAL SALUTATION.}

READER, these travels of mine into Scotland were not undertaken either in imitation or emulation of any man, but only devised by myself, on purpose to make trial of my friends both in this Kingdom of England and that of Scotland, and because I would be an eye-witness of divers things which I had heard of that country. And whereas many shallow-brained critics do lay an aspersion on me, that I was set on by others, or that I did undergo this project either in malice or mockery of Mr. Benjamin Jonson, I vow by the faith of a Christian that their imaginations are all wide, for be is a gentleman to whom I am so much obliged for many undeserved courtesies that $I$ have received from him, and from others by his favour, that I durst never to be so impudent or ungrateful as either to suffer any man's persuasions or mine own instigation to incite me to make so bad a requital for so much goodness formerly received. So much for that; and uow, Reader, if you expect

That I should write of eities' situations,

Or that of countries I should make relations :

Of brooks, crooks, nooks; of rivers, bournes, and rills,

Of mountains, fountains, castles, towers and hills,

Of shires, and piers, and memorable things,

Of lives and deaths of great commanding kings,

I touch not those, they not belong to me;

But if such things as these you long so see,

Lay down my book, and but vouchsafe to read

The learned Camden, or laborious Speed. 


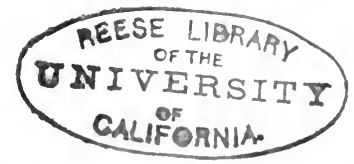

\section{The Penniless Pilgrimage.}

LIST lordlings, list, if you have lust to list, I write not here a tale of had I wist:

But you shall hear of travels, and relations, Descriptions of strange, yet English fashions. And he that not believes what here is writ, Let him, as I have done, make proof of it. The year of grace, accounted, as I ween, One thousand twice three hundred and eighteen, And to relate all things in order duly, 'Twas Tuesdlay last, the fourteenth day of July, Saint Revels day, the almanack will tell ye The sign in Virgo was, or near the belly: The moon full three days old, the wind full south; At these times I began this trick of youth. I speak not of the tide, for understand, My legs I made my oars, and rowed by land, Though in the morning I began to go Good fellows trooping, flocked me so, That make what haste I could, the sun was set, E'er from the gates of London I could get. At last I took my latest leave thus late, At the Bell Inn, that's extra Aldersgate. There stood a horse that my provant should carry, From that place to the end of my fegary, My horse no horse, or mare, but gelded nag, That with good understanding bore my bag: And of good carriage he himselfe did show, These things are excellent in a beast you know. There in my knapsack, to pay hunger's fees, 
I had good bacon, biscuit, neat's-tongue, cheese

With roses, barberries of each conserves,

And mithridate, that vigorous health preserves:

And I entreat you take these words for no-lies,

I had good aqua vitæ, Rosa so-lies :

With sweet ambrosia, the gods' own drink,

Most excellent gear for mortals, as I think,

Besides, I had both vinegar and oil,

That could a daring saucy stomach foil.

This foresaid Tuesday night 'twixt eight and nine,

Well rigged and ballasted, both with beer and wine,

I stumbling forward, thus my jaunt begun,

And went that night as far as Islington.

There did I find, I dare affirm it bold,

A maidenhead of twenty-five years old, But surely it was painted, like a $\mathrm{w}-\mathrm{e}$, And for a sign, or wonder, hanged at a door, Which shows a maidenhead, that's kept so long, May be hanged up, and yet sustain no wrong. There did my loving friendly host begin To entertain me freely to his inn : And there my friends, and good associates, Each one to mirth himself accommodates. At Well-head both for welcome, and for cheer, Having a good New ton, of good stale beer : There did we trundle down health, after health, Which often times impairs both health and wealth. 'Till everyone had filled his mortal trunk, And only no-body was three parts drunk. The morrow next, Wednesday, Saint Swithin's day, From ancient Islington I took my way. At Holywell I was enforced carouse, Ale high, and mighty, at the Blindman's House. But there's a help to make amends for all, That though the ale be great, the pots be small. At Highgate Hill to a strange house I went, And saw the people were to eating bent, In either borrowed, craved, asked, begged, or bought, But most laborious with my teeth I wrought. I did not this, 'cause meat or drink was scant, 
But I did practise thus before my want; Like to a tilter that would win the prize, Before the day he'll often exercise.

So I began to put in use, at first

These principles 'gainst hunger, 'gainst thirst.

Close to the gate, there dwelt a worthy man, That well eould take his whiff, and quaff his ean, Right Robin Good-fellow, but humours evil, Do call him Robin Pluto, or the devil. But finding him a devil, freely hearted, With friendly farewells I took leave and parted, And as alongst I did my journey take, I drank at Broom's well, for pure fashion's sake, Two miles I travelled then without a bait, The Saracen's Head at Whetstone entering straight, I found an host, that might lead an host of men, Exceeding fat, yet named Lean and Fen. And though we make small reekoning of him here, He's known to be a very great man there. There I took leave of all my company, Bade all farewell, yet spake to no-body. Good reader think not strange, what I compile, For no-body was with me all this while. And no-body did drink, and wink, and scink, And on oceasion freely spent his chink. If anyone desire to know the man, Walk, stumble, trundle, but in Barbican. There's as good beer and ale as ever twang'd, And in that street kind no-body is hanged. But leaving him to his matchless fame, I to St. Albans in the evening eame, Where Master Taylor, at the Saracen's Head, Unasked, unpaid for, me both lodged and fed. The tapsters, hostler's, chamberlains, and all, Saved me a labour, that I need not call, The jugs were filled and filled, the cups went round, And in a word great kindness there I found, For which both to my cousin, and his men, I'll still be thankful in word, deed, and pen, Till Thursday morning there I made my stay, 
And then I went plain Dunstable highway. My very heart with drought methought did shrink, I went twelve miles, and no one bade me drink. Which made me call to mind, that instant time, That drunkenness was a most sinful crime. When Puddle-hill I footed down, and past A mile from thence, I found a hedge at last. There stroke we sail, our bacon, cheese, and bread, We drew like fiddlers, and like farmers fed. And whilst two hours we there did take our ease, My nag made shift to mump green pulse and peas. Thus we our hungry stomachs did supply, And drank the water of a brook hard by. Away toward Hockley in the hole, we make, When straight a horseman did me overtake, Who knew me, and would fain have given me coin, I said, my bonds did me from coin enjoin, I thanked and prayed him to put up his chink, And willingly I wished it drowned in drink. Away rode he, but like an honest man; I found at Hockley standing at the Swan. A formal tapster, with a jug and glass, Who did arrest me: I most willing was To try the action, and straight put in bail, My fees were paid before, with sixpence ale, To quit this kindness, I most willing am, The man that paid for all, his name is Dam, At the Green Dragon, against Grays-Inn gate, He lives in good repute, and honest state. I forward went in this my roving race, To stony Stratford I toward night did pace, My mind was fixed through the town to pass, To find some lodging in the hay or grass, But at the Queen's Arms, from the window there, A comfortable voice I chanced to hear, Call 'Taylor, Taylor, and be hanged come hither, I looked for small entreaty and went thither, There were some friends, which I was glad to see, Who knew my journey; lodged, and boarded me. On Friday morn, as I would take my way, 
My friendly host entreated me to stay, Because it rained, he told me I should have Meat, drink, and horse-meat, and not pay or crave. I thanked him, and for his love remain his debtor, But if I live, I will requite him better.

From stony Stratford, the way hard with stones, Did founder me, and vex me to the bones. In blustering weather, both for wind and rain, Through Towcester I trotted with much pain, Two miles from thence, we sat us down and dined, Well bulwarked by a hedge, from rain and wind.

We having fed, away incontinent,

With weary pace toward Daventry we went. Four miles short of it, one o'ertook me there, And told me he would leave a jug of beer, At Daventry at the Horse-shoe for my use. I thought it no good manners to refuse, But thanked him, for his kind unasked gift, Whilst I was lame as scarce a leg could lift, Came limping after to that stony town, Whose hard streets made me almost halt right down. There had my friend performed the words he said, And at the door a jug of liquor staid, The folks were all informed, before I came, How, and wherefore my journey I did frame, Which caused mine hostess from her door come out, Having a great wart rampant on her snout. The tapsters, hostlers, one another call, The chamberlains with admiration all, Were filled with wouder, more than wonderful, As if some monster sent from the Mogul, Some elephant from Africa, I had been, Or some strange beast from the Amazonian Queen. As buzzards, widgeons, woodcocks, and such fowl, Do gaze and wonder at the broad-faced owl,

So did these brainless asses, all amazed, With admirable nonsense talked and gazed, They knew my state, although not told by me, That I could scarcely go, they all could see, They drank of my beer, that to me was given, 
But gave me not a drop to make all even, And that which in my mind was most amiss, My hostess she stood by and saw all this. Had she but said, come near the house my friend, For this day here shall be your journey's end, Then had she done the thing which she did not, And I in kinder words had paid the shot. I do entreat my friends, as I have some, If they to Daventry do chance to come, That they will baulk that inn; or if by chance, Or accident into that house they glance, Kind gentlemen, as they by.you reap profit, My hostess care of me, pray tell her of it, Yet do not neither; lodge there when you will, You for your money shall be welcome still. From thence that night, although my bones were sore, I made a shift to hobble seven miles more: The way to Dunchurch, foul with dirt and mire, Able, I think, both man and horse to tire. On Dunsmoor Heath, a hedge doth there enclose Grounds, on the right hand, there I did repose. Wit's whetstone, want, there made us quickly learn, With knives to cut down rushes, and green fern, Of which we made a field-bed in the field, Which sleep, and rest, and much content did yield. 'I'here with my mother earth, I thought it fit To lodge, and yet no incest did commit: My bed was curtained with good wholesome airs, And being weary, I went up no stairs : The sky my canopy, bright Phobe shined, Sweet bawling zephyrus breathed gentle wind, In heaven's star-chamber I did lodge that night, Ten thousand stars, me to my bed did light; There barricadoed with a bank lay we Below the lofty branches of a tree, There my bed-fellows and companions were, My man, my horse, a bull, four cows, two steer : But yet for all this most confused rout, We had no bed-staves, yet we fell not out. Thus nature, like an ancient free upholster, 
Did furnish us with bedstead, bed, and bolster ;

And the kind skies, for which high heaven be thanked, Allowed us a large covering and a blanket; Auroras' face 'gan light our lodging dark, We arose and mounted, with the mounting lark, Through plashes, puddles, thick, thin, wet and dry, I travelled to the city Coventry.

There Master Doctor Holland caused me stay

The day of Saturn and the Sabbath day. Most friendly welcome, he me did affird, I was so entertained at bed and board, Which as I dare not brag how much it was, I dare not be ingrate and let it pass, But with thanks many I remember it, Instead of his good deods, in words and writ, He used me like his son, more than a friend, And he on Monday his commends. did send To Newhall, where a gentleman did dwell, Who by his name is hight Sacheverell. The Tuesday July's one and twentieth day, I to the city Lichfield took my way, At Sutton Coldfield with some friends I met, And much ado I had from thence to get, There I was almost put unto my trumps, My horse's shoes were worn as thin as pumps; But noble Vulcan, a mad smuggy smith, All reparations me did furnish with. The shoes were well removed, my palfrey shod, And he referred the payment unto God. I found a friend, when I to Lichfield came, A joiner, and John Piddock is his name. He made me welcome, for he knew my jaunt, And he did furnish me with good provant: He offered me some money, 1 refused it, And so I took my leave, with thanks excused it. That Wednesday, I a weary way did pass, Rain, wind, stones, dirt, and dabbling dewy grass, With here aud there a pelting scattered village, Which yielded me no charity, or pillage : For all the day, nor yet the night that followed, 
One drop of drink I'm sure my gullet swallowed. At night I came to a stony town called Stone, Where I knew none, nor was I known of none: I therefore through the streets held on my pace, Some two miles farther to some resting place: At last I spied a meadow newly mowed,

The hay was rotten, the ground half o'erflowed:

We made a breach, and entered horse and man,

Then our pavilion we to pitch began,

Which we erected with green broom and hay,

To expel the cold, and keep the rain away;

The sky all muffled in a cloud 'gan lower, And presently there fell a mighty shower, Which without intermission down did pour, From ten a night, until the morning's four. We all that time close in our couch did lie, Which being well compacted kept us dry. The worst was, we did neither sup nor sleep, And so a temperate diet we did keep. The morning all enrobed in drifting fogs, We being as ready as we had been dogs: We need not stand upon long ready making, But gaping, stretching, and our ears well shaking : And for I found my host and hostess kind, I like a true man left my sheets behind. That Thursday morn, my weary course I framed, Unto a town that is Newcastle named. Not that Newcastle standing upon 'Tyne, But this town situation doth confine Near Cheshire, in the famous county Stafford, And for their love, I owe them not a straw for't;

But now my versing muse craves some repose, And whilst she sleeps I'll spout a little prose.

In this town of Newcastle, I overtook an hostler, and I asked him what the next town was called, that was in my way toward Lancaster, he holding the end of a riding rod in his mouth, as if it had been a flute, piped me this answer, and said, Talk-on-the-Hill ; I asked him again what he said, Talk-on-the-Hill : I demanded the third time, and the third time he answered me as he did before, 
Talk-on-the-Hill. I began to grow choleric, and asked him why he could not talk, or tell me my way as well there as on the hill; at last I was resolved, that the next town was four miles off me, and that the name of it was, Talk-on-the-Hill: I had not travelled above two miles farther; but my last night's supper, which was as much as nothing, my mind being informed of it by my stomach. I made a virtue of necessity, and went to breakfast in the Sun. I have fared better at three Suns many times before now, in Aldersgate Street, Cripplegate, and new Fish Street; but here is the odds. at those Suns they will come upon a man with a taveru bill as sharp cutting as a tailor's bill of items: a watchman's-bill, or a welshhook falls not half so heavy upon a man; besides, most of the vintners have the law in their own hands, and have all their actions, cases, bills of debt, and such reckonings tried at their own bais; from whence there is no appeal. But leaving these impertinences, in the material sunshine, we eat a substantial dinner, and like miserable guests we did budget up the reversions. .

And now with sleep my muse hath eased her brain, I'll turn my style trom prose, to verse again. That which we could not have, we freely spared, And wanting drink, most soberly we fared. We had great store of fowl, but 'twas foul way, And kindly every step entreats me stay, The clammy clay sometimes my heels would trip, One foot went forward, the other back would slip. This weary day, when I had almost past, I came unto Sir Urian Leigh's at last, At Adlington, near Macclesfield he doth dwell, Beloved, respecter, and reputed well. Through his great love, my stay with him was fixed, From 'I'hnrsday night, till noon on Monday next. At his own table I did daily eat, Whereat may be supposed, did want no meat, He would have given me gold or silver either, But I, with many thanks, received neither. And thus much without flattery, I dare swear, He is a knight beloved far and near. 
First he's beloved of his God above, Which love he loves to keep, beyond all love, Next with a wife and children he is blest, Each having God's fear planted in their breast. With fair demaines, revenue of good lands, He's fairly blessed by the Alnighty's hands. And as he's happy in these outward things, So from his inward mind continual springs Fruits of devotion, deeds of piety, Good hospitable works of charity. Just in his actions, constant in his word, And one that won his honour with the sword, He's no carranto, cap'ring, carpet knight, But he knows when, and how to speak or fight:

I cannot flatter him, say what I can, He's every way a complete gentleman. I write not this, for what he did to me, But what mine ears, and eyes did hear and see, Nor do I pen this to enlarge his fame, But to make others imitate the same; For like a trumpet were I pleased to blow, I would his worthy worth more amply show ; But I already fear have been too bold, And crave his pardon, me excused to hold. Thanks to his sons and servants every one, Both males and temales all, excepting none. To bear a letter he did me require,

Near Manchester, unto a good Esquire : His kinsman Edmund Prestwitch, he ordained, That I was at Manchester entertained Two nights, and one day, ere we thence could pass, For men and horse, roast, boiled, and oats, and grass; This gentleman not only gave harbour, But in the morning sent me to his barber, Who laved, and shaved me, still I spared my purse, Yet sure he left me many a hair the worse. But in conclusion, when his work was ended, His glass informed, my face was much amended. And for the kindness he to me did show, God grant his customers beards faster grow, 
That though the time of year be dear or cheap, From fruitful faces he may mow and reap. Then came a smith, with shoes, and tooth and nail, He searched my horse's hoofs, mending what did fail, Yet this I note, my nag, through stones and dirt, Did shift shoes twice, ere I did shift one shirt:

Can these kind things be in oblivion hid? $\mathrm{No}$, Master Prestwich, this and much more did, His firendship did command and freely gave All before writ, and more than I durst crave. But leaving him a little, I must tell, How men of Manchester did use me well. Their loves they on the tender-hooks did rack, Roast, boiled, baked, too-too-much, white, claret, sack, Nothing they thought too heavy or too hot, Can followed can, and pot succeeded pot; That what they could do, all they thought too little, Striving in love the traveller to whittle. We went into the house of one John Pinners, A man that lives amongst a crew of sinners, And there eight several sorts of ale we had, All able to make one stark drunk or mad. But I with courage bravely flinched not, And gave the town leave to discharge the shot.

We had at one time set upon the table, Good ale of hyssop, 'twas no Esop-fable : Then had we ale of sage, and ale of malt, And ale of wormwood, that could make one halt, With ale of rosemary, and betony, And two ales more, or else I needs must lie. But to conclude this drinking aley-tale, We had a sort of ale, called scurvy ale. Thus all these men, at their own charge and cost, Did strive whose love should be expressed most, And farther to declare their boundless loves, They saw I wanted, and they gave me gloves; In deed, and very deed, their loves were such, That in their praise I cannot write to much. They merit more than I have here compiled, I lodged at the Eagle and the Child, 
Whereas my hostess, a good ancient woman,

Did entertain me with respect, not common.

She caused my linen, shirts, and bands be washed, And on my way she caused me be refreshed;

She gave me twelve silk points, she gave me bacon, Which by me much refused, at last was taken.

In troth she proved a mother unto me, For which, I evermore will thankful be; But when to mind these kindnesses I call, Kind Master Prestwitch author is of all; And yet Sir Urian Leigh's good commendation Was the main ground of this my recreation. From both of them, there what I had, I had, Or else my entertainment had been bad. $\mathrm{O}$ all you worthy men of Manchester, True bred bloods of the County Lancaster, When I forget what you to me have done, 'I hen let me headlong to confusion run. To noble Master Prestwitch I must give Thanks, upon thanks, as long as I do live. His love was such, I ne'er can pay the score, He far surpassed all that went before. A horse and man he sent, with boundless bounty, To bring me quite through Lancaster's large county, Which I well know is fifty miles at large, And he defrayed all the cost and charge. This unlooked pleasure, was to me such pleasure, That I can ne'er express my thanks with measure. So Mistress Saracoal, hostess kind, And Manchester with thanks I left behind. The Wednesday being July's twenty nine, My journey I to Preston did confine. Ail the day long it rained but one shower, Which from the morning to the evening did pour, And I, before to Preston I could get, Was soused, and pickled both with rain and sweat; But there I was supplied with fire and food, And anything I, wanted sweet and good. There, at the Hind, kind Master Hind mine host, Kept a good table, baked and boiled, and roast. 
There Wednesday, Thursday, Friday, I did stay, And hardly got from thence on Saturday. Unto my lodging often did repair, Kind Master 'Thomas Banister, the mayor, Who is of worship, and of good respect, And in his charge discreet and circumspect. For I protest to God I never saw,

A town more wisely governed by the law.

They told me when my Sovereign there was last, That one man's rashness seemed to give distaste. It grieved them all, but when at last they found, His Majesty was pleased, their joys were crowned. He knew, the fairest garden hath some weeds; $\mathrm{He}$ did accept their kind intents, for deeds : One man there was, that with his zeal too hot, And furious haste, himself much overshot. But what man is so foolish, that desires To get good fruit from thistles, thorns and briars? Thus much I thought good to demonstrate here, Because I saw how much they grieved were; That any way, the least part of offence, Should make them seem offensive to their prince. Thus three nights was I staid and lodged in Preston, And saw nothing ridiculous to jest on. Much cost and charge the mayor upon me spent, And on my way two miles, with me he went. There, by good chance, I did more friendship get, 'The under Sheriff of Lancashire we met, A gentleman that loved, and knew me well, And one whose bounteous mind doth bear the bell. There, as if I had been a noted thief, The mayor delivered me unto the sheriff. The sheriff's authority did much prevail, He sent me unto one that kept the jail. Thus I perambuling, poor John Taylor, Was given from mayor to sheriff, from sheriff to jailor. The jailor kept an inn, good beds, good cheer, Where paying nothing, I found nothing dear, For the under-sheriff, kind Master Covill named, A man for house-keeping renowned and famed, 
Did cause the town of Lancashire afford Me welcome, as if I had been a lord. And 'tis reported, that for daily bounty, His mate can scarce be found in all that county. The extremes of miser, or of prodigal, He shuns, and lives diccreet and liberal. His wife's mind, and his own are one, so fixed, That Argus eyes could see no odds betwixt, And sure the difference, if there difference be, Is who, shall do most good, or he, or she. Poor folks report, that for relieving them, He and his wife, are each of them a gem; At the inn, and at his house two nights I staid, And what was to be paid, I know he paid: If nothing of their kindness I had wrote, Ungrateful me the world might justly note : Had I declared all I did hear, and see, For a great flatterer then I deemed should be. Him, and his wife, and modest daughter Bess, With earth, and heaven's felicity, God bless. Two days a man of his, at his command, Did guide me to the midst of Westmoreland, And my conductor with a liberal fist, To keep me moist, scarce any alehouse missed. The fourth of August, weary, halt, and lame, We in the dark, to a town called Sedbergh came, There Master Borrowed, my kind honest host, Upon me did bestowed unasked cost. The next day I held on my journey still, Six miles unto a place called Carling hill, Where Master Edmund Branthwaite doth reside, Who made me welcome, with my man and guide. Our entertainment, and our fare were such, It might have satisfied our betters much ; Yet all too little was, his kind heart thought, And five miles on my way himself me brought. At Orton he, I, and my man did dine, With Master Corney a good true divine, And súrely Master Branthwaite's well beloved, His firm integrity is much approved: 
His good effects, do make him still affected Of God and good men, with regard, respected. He sent his man with me, o'er dale and down, Who lodged, and boarded me at Penrith town, And such good cheer, and bedding there I had, That nothing, but my weary self was bad; There a fresh man, I know not.for whose sake, With me a journey would to Carlisle make: But from that city, about two miles wide, Good Sir John Dalston lodged me and my guide.

Of all the gentlemen in England's bounds His house is nearest to the Scottish grounds, And fame proclaims him, far and near, aloud, He's free from being covetous, or proud;

- His son, Sir George, most affable, and kind, His father's image, both in form and mind, On Saturday to Carlisle both did ride, Where, by their loves and leaves, I did abide, Where of good entertainment I found store, From one that was the mayor the year before; His name is Master Adam Robinson, I the last English friendship with him won. $\mathrm{He}$, gratis, found a guide to bring me through, From Carlisle to the city Edinburgh: This was a help, that was a help alone, Of all my helps inferior unto none.

Eight miles from Carlisle runs a little river,

Which England's bounds, from Scotland's grounds doth sever:

Without horse, bridge, or boat, I o'er did get On foot, I went, yet searce my shoes did wet. I being come to this long-looked-for land, Did mark, remark, note, renote, viewed, and scanned; And I saw nothing that could change my will, But that I thought myself in England still. The kingdoms are so nearly joined and fixed, There scarcely went a pair of shears betwixt; There I saw sky above, and earth below, And as in England, there the sun did show; The hills with sheep replete, with corn the dale, 


\section{EARLY PROSE AND POETICAL WORKS.}

And many a cottage yielded good Scottish ale; This county, Avondale, in former times, Was the cursed climate of rebellious crimes: For Cumberland and it, both kingdoms borders, Were ever ordered, by their own disorders. Some sharking, shifting, cutting throats, and thieving, Each taking pleasure in the other's grieving; And many times he that had wealth to-night, Was by the morrow morning beggared quite: Too many years this pell-mell fur'y lasted, That all these borders were quite spoiled and wasted, Confusion, hurly-burly reigned and revelled, The churches with the lowly ground were levelled; All memorable monuments defaced, All places of defence o'erthrown and razed. That whoso then did in the borders dwell, Lived little happier than those in hell. But since the all-disposing God of heaven, Hath these two kingdoms to one monarch given, Blest peace, and plenty on them both have showered, Exile, and hanging hath the thieves devoured, That now each subject may securely sleep, His sheep and neat, the black the white doth keep, For now those crowns are both in one combined, Those former borders, that each one confine, Appears to me, as I do understand, To be almost the centre of the land. This was a blessed heaven expounded riddle, To thrust great kingdom's skirts into the middle. Long may the instrumental cause survive. From him and his, succession still derive True heirs unto his virtues, and his throne, That these two kingdoms ever may be one; This county of all Sicotland is most poor, By reason of the outrages before, Yet mighty store of corn I saw there grow, And as good grass as ever man did mow : And as that day I twenty miles did pass, I saw eleven hundred neat at grass, By which may be conjectured at the least, 
That there was sustenance for man and beast. And in the kingdom I have truly scanned, There's many worser parts, are better mauned, For in the time that thieving was in ure, The rentles fled to places more secure, And left the poorer sort, to abide the pain, Whilst they could ne'er find time to turn again. The shire of gentlemen is scarce and dainty, Yet there's relief in great abundance plenty. 'Twixt it and England, little odds I' see, They eat, and live, and strong and able be. So inuch in verse, and now I'll change my style, And seriously I'll write in prose a while.

To the purpose then: my first night's lodging in Scotland was at a place called Moffat, which they say, is thirty miles from Carlisle, but I suppose them to be longer than forty of such miles as are betwixt. London and Saint Albans, but indeed the Scots do allow almost as large measure of their miles, as they do of their drink, for an English gallon, either of ale or wine, is but their quart, and one Scottish mile, now and then, may well stand for a mile and a half or two English, but howsoever short or long, I found that day's journey the weariest that ever I footed; and at night, being come to the town, I found good ordinary country entertainment: my fare and my lodging was sweet and good, and might have served a far better man than myself, although myself have had many times better: but this is to be noted, that though it rained not all the day, yet it was my fortune to be well wet twice, for I waded over a great river called Esk in the morning, somewhat more than four miles distance from Carlisle in England, and at night within two miles of my lodging, I was fain to wade over the river of Annan in Scotland, from which river the county of Annandale hath its name. And whilst I waded on foot, my man was mounted on horseback, like the George without the Dragon. But the next morning, I arose and left Mrffat behind me, and that day I travelled twentyone miles to a sorry village called Blythe, but I was blithe 
myself to come to any place of harbour or succour, for since I was born, I never was so weary, or so near being dead with extreme travel: I was foundered and refoundered of all four, and for my better comfort, I came so late, that I must lodge without doors all night, or else in a poor house where the good wife lay in child-bed, her husband being from home, her own servant maid being; her nurse. A creature naturally compacted, and artificially adorned with an incomparable homeliness: but as things were I must either take or leave, and necessity made me enter, where we got eggrs and ale by measure and by tail. At last to bed I went, my man lying on the floor by me, where in the night there were pigeons did very bountifully mute in his face: the day being no sooner come, and having but fifteen miles to Edinburgh, mounted upon my ten toes, and began first to hobble, and after to amble, and so being warm, I fell to pace by degrees; all the way passing through a fertile country for corn and cattle: and about two of the clock in the afternoon that Wednesday, being the thirteenth of August, and the day of Clare the Virgin (the sign being in Virgo) the moon four days old, the wind at west, I came to take rest, at the wished, long expected, ancient famous city of Edinburgh, which I entered like Pierce Penniless, altogether moneyless, but I thank God, not friendless; for being there, for the time of my stay, I might borrow, if any man would lend, spend if I could get, beg if I had the impudence, and steal, if I durst adventure the price of a hanging, but my purpose was to house my horse, and to suffer him and my apparel to lie in durance, or lavender instead of litter, till such time as I could meet with some valiant friend that would. desperately disburse.

Walking thus down the street, my body being tired with travel, and my mind attired with moody, muddy, Moor-ditch melancholy, my contemplation did devotedly pray, that I might meet one or other to prey upon, being willing to take any slender acquaintance of any map whatsoever, viewing, and circumventing every man's face I met, as if I meant to draw his picture, but all my ac- 
quaintanee was Non est Inventus; pardon me, reader, that Latin is none of my own, I swear by Priscian's Pericranium, an oath which I have ignorantly broken many times. At last I resolved, that the next gentleman that I meet withal, should be acquaintance whether he would or no: and presently fixing mine eyes upon a gentlemanlike object, I looked on him, as if I would survey something through him, and make him my perspective: and he much musing at my gazing, and I much gazing at his musing, at last he crossed the way and made toward me, and then I made down the street from him, leaving to encounter with my man, who came after me leading my horse, whom he thus acersted. My friend, quoth he, doth yonder gentleman, meaning me, know me, that he looks so wistly on me? Truly sir, said my -man, I think not, but my master is a stranger come from London, and would gladly meet some aequaintance to direct him, where he may have lodging and horse-meat. Presently the gentleman, being of a generous disposition, overtook me with unexpeeted and undeserved courtesy, brought me to a lodging, and caused my horse to be put into his own stable, whilst we discoursing over a pint of Spanish, I relate as much English to him, as made him lend me ten shillings, his name was Master John Maxwell, which money I am sure was the first that I handled after 1 eame from out the walls of London: but having rested two hours and refreshed myself, the gentleman and I walked to see the City and the Castle, which as ny poor unable and unworthy pen can, I will truly describe.

The castle on a lofty rock is so strongly grounded, bounded, and founded, that by foree of man it can never be confounded, the foundation and walls are unpenetrable, the rampiers impregnable, the bulwarks invincible, no way but one it is or can be possible to be made passible. In a word, I have seen many straits and fortresses, in Germany, the Netherlands, Spain and England, but they must all give place to this unconquered Castle, both for strength and situation.

Amongst the many memorable things which I was shewed there, I noted especially a great piece of ordnance 
of iron, it is not for battery, but it will serve to defend a breach, or to toss balls of wild-fire against any that should assail or assault the Castle; it lies now dismounted. And it is so great within, that it was told me that a child was once gotten there: but I, to make trial crept into it, lying on my back, and I am sure there was room enough and spare fur a greater than myself.

So leaving the castle, as it is both defensive against my opposition, and magnific for lodging and receite, I descended lower to the city, wherein I observed the fairest and goodliest street that ever mine eyes beheld, for I did never see or hear of a street of that length, which is half an English mile from the castle to a fair port which they call the Nether-Bow, and from that port, the street which they call the Kenny-gate is one quarter of a mile more, down to the King's Palace, called Holyrood House, the buildings on each side of the way being all of squared stone, five, six, and seven stories high, and many byelanes and closes on each side of the way, wherein are gentlemen's houses, much fairer than the buildings in the High Street, for in the High Street the merchants and tradesmen do divell, but the gentlemen's mansions and goodliest houses are obscurely founded in the aforesaid lanes: the walls are eight or ten foot thick, exceeding strong, not built for a day, a week, or a month, or a year; but from antiquity to posterity, for many ages; there I found entertainment beyond my expectation or merit, and there is fish, flesh, bread and fruit, in such variety, that I think I may offenceless call it superfuity, or satiety. The worst was, that wine and ale was so scarce, and the people there such misers of it, that every night before I went to bed, if any man had asked me a civil question, all the wit in my head could not have made him a sober answer.

I was at his Majesty's Palace, a stately and princely. seat, wherein I saw a sumptuous chapel, most richly adorned with all appurtenances belonging to so sacred a place, or so royal an owner. In the imner court I saw the King's arms cunningly carved in stone, and fixed over a door aloft on the wall, the red lion being in the crest, over which was written this inscription in Latin, 


\section{Nolis hace invicta miserunt, 106 proavi.}

I enquired what the English of it was? it was told me as followeth, which I thought worthy to be recorded.

\section{6 forefathers have left this to us unconquered.}

This is a worthy and memorable motto, and I think few kingdoms or none in the world can truly write the like, that notwithstanding so many inroads, incursions, attempts, assaults, civil wars, and foreign hostilities, bloody battles, and mighty foughten fields, that maugre the strength and policy of enemies, that royal crown and sceptre hath from one hundred and seven descents, kept still unconquered, and by the power of the King of Kings, through the grace of the Prince of Peace, is now left peacefully to our peaceful king, whom long in blessed peace, the God of peace defend and govern.

But once more, a word or two of Edinburgh, although I have scarcely given it that due which belongs unto it, for their lofty and stately buildings, and for their fair and spacious streets, yet,my mind persuades me that they in former ages that first founded that city did not so well in that they built it in so discommodious a place; for the sea, and all navigable rivers being the chief means for the enriching of towns and cities, by the reason of traffic with foreign nations, with exportation, transportation, and receite of variety of merchandizing; so this city had it been built but one mile lower on the seaside, I doubt not but it liad long before this been comparable to many a one of our greatest towns and cities in Europe, both for spaciousness of bounds, port, state, and riches. It is said, that King James the Fifth, of famous memory, did graciously offer to purchase for them, and to bestow upon them freely, certain low and pleasant grounds a mile from them on the seashore, with these conditions, that they should pull down their city, and build it in that more commodious place, but the citizens refused it; and so now it is like, for me, to stand where it doth, for I doubt such another proffer of removal will not be presented to them, till two days after the fair. 
Now have with you for Leith, whereto I no sooner came, but I was well entertained by Master Barnard Lindsay, one of the grooms of his Majesties bed-chamber, he knew my estate was not guilty, because I brought guilt with me, more than my sins, and they would not pass for current there, he therefore did replenish the vaustity of my empty purse, and discharged a piece at me with two bullets of gold, each being in value worth eleven shillings white money; and I was creditably informed, that within the compass of one year, there was shipped away from that only port of Leith, fourscore thousand boles of wheat, oats, and barley into Spain, France, and other foreign parts, and every bole contains the measure of four English bushels, so that from Leith only hath been transported three hundred and twenty thousand bushels of corn; besides some hath been shipped away from Saint Andrews, from Dundee, Aberdeen, Dysart, Kirkaldy, Kinghorn, Burntisland, Dunbar, and other portable towns, which makes me to wonder that a kingdom so populous as it is, should nevertheless sell so much bread-corn beyond the seas, and yet to have more than sufficient for themselves.

So I having viewed the haven and town of Leith, took a passage boat to see the new wondrous Well, to which many a one that is not well, comes far and near in hope to be made well: indeed I did hear that it had done much good, and that it hath a rare operation to expel or kill divers maladies; as to provoke appetite, to help much for the avoiding of the gravel in the bladder, to cure sore eyes, and old ulcers, with many other virtues which it hath, but I, through the mercy of God, having no need of it, did make no great inquisition what it had done, but for novelty I drank of it and I found the taste to be more pleasant than any other water, sweet almost as milk, yet as clear as crystal, and I did observe that though a man did drink a quart, a pottle, or as much as his belly coula contain, yet it never offended or lay heavy upon the stomach, no more than if one had drank but a pint or a small quantity.

I went two miles from it to a town called Burntisland, 
where I found many of my especial good friends, as Master Robert Hay, one of the Grooms of his Majesty's Bed-chamber, Master David Drummond, one of his Gentlemen's-Pensioners, Master James Acmootye, one of the Grooms of the Privy Chamber, Captain Murray, Sir Henry Witherington Knight, Captain 'Tyrie, and divers others: and there Master Hay, Master Drummond, and the good old Captain Murray did very bountifully furnish me with gold for my expenses, but I being at dimner with those aforesaid gentlemen, as we were discoursing, there befel a strange accident, which I think worth the relating.

I know not upon what occasion they began to talk of being at sea in former times, and I, amongst the rest, said, I was at the taking of Cadiz; whereto an English gentleman replied, that he was the next good voyage after at the Islands; I answered him that I was there also. He demanded in what ship I was? I told him in the Rainbow of the Queens: why, quoth he, do you not know me? I was in the same ship, and my name is Witherington.

Sir, said I, I do remember the name well, but by reason it is near two and twenty years since I saw you, I may well forget the knowledge of you. Well said he, if you were in that ship, I pray you tell me some remarkable token that happened in the voyage, whereupon I told him two or three tokens; which he did know to be true. Nay then, said I, I will tell you another which, perhaps, you have not forgotten; as our ship and the rest of the fleet did ride at anchor at the Isle of Flores, one of the Isles of the Azores, there were some fourteen men and boys of our ship, that for novelty would go ashore, and see what fruit the island did bear, and what entertainment it would yield us; so being landed, we went up and down and could find nothing but stones, heath and moss, and we expected oranges, lemons, figs, musk-mellions, and potatoes; in the mean space the wind did blow so stiff, and the sea was so extreme rough, that our ship-boat could not come to the land to fetch us, for fear she should be beaten in pieces against the rocks; this continued five days, so that we were almost famished for want of food: 
but at last, I squandering up and down, by the providence of God I happened into a cave or poor habitation, where I found fifteen loaves of bread, each of the quantity of a penny loaf in England, I having a valiant stomach of the age of almost of a hundred and twenty hours breeding, fell to, and ate two loaves and never said grace, and as I was about to make a horse-loaf of the third loaf, I did put twelve of them into my breeches, and my sleeves, and so went mumbling out of the cave, leaning my back against a tree, when upon the sudden a gentleman came to me, and said, "Friend, what are you eating? Bread, quoth I, for God's sake, said he, give me some. With that, I put my hand into my breech, being my best pantry, and I gave him a loaf, which he received with many thanks, and said, that if ever he could requit it, he would.

I had no sooner told this tale, but Sir Henry Witherington did acknowledge himself to be the man that I had given the loaf unto two and twenty years before, where I found the proverb true, that men have more privilege than mountains in meeting.

In what great measure he did requite so small a courtesy, I will relate in this following discourse in my return through Northumberland: so leaving my man at the town of Burntisland, I told him I would but go to Stirling, and see the Castle there, and withal to see my honourable friends the Earl of Mar, and Sir William Murray Knight, Lord of Abercairney, and that I would return within two days at the most: but it fell out quite contrary; for it was and five and thirty days before I could get back again out of these noble men's company. The whole progress of my travel with them, and the cause of my stay I cannot with gratefulness omit; and thus it was.

A worthy gentleman named Master John F'enton, did bring me on my way six miles to Dunfermline, where I was well entertained, and lodged at Master John Gibb his house, one of the Grooms of his Majesty's Bedchamber, and I think the oldest servant the King hath : withal, I was well entertained there by Master Crighton at his own house, who went with me, and shewed me the 
Queen's Palace; a delicate and princely mansion, withal I saw the ruins of an ancient and stately built Abbey, with fair gardens, orchards, meadows, belonging to the Palace: all which with fair and goodly revenues by the suppression of the Abbey, were annexed to the crown. There also I saw a very fair church, which though it be now very large and spacious, yet it hath in former times: been much larger. But I taking my leave of Dunfermline, would needs go and see the truly noble Knight Sir George Bruce, at a town called the Culross: there he made me right welcome, both with variety of fire, and after all, he commanded three of his men to direct me to see his most admirable coal mines; which, if man can or could work wonders, is a wonder ; for myself, neither in any travels that I have been in, nor any history that I have read, or any discourse that I have heard, did never see, read, or hear, of any work of man that might parallel or be equivalent with this unfellowed and unmatchable work: and though all I can say of it, cannot describe it according to the worthiness of his vigilant industry, that was both the occasion, inventor, and maintainer of it: yet rather than the memory of so rare an enterprise, and so accomplished a profit to the commonwealth shall be raked and sinothered in the dust of oblivion, I will give a little touch at the description of it, although I amongst writers, am like he that worse may hold the candle.

The mine hath two ways into it, the one by sea and the other by land; but a man may go into it by land, and return the same way if he please, and so he may enter into it by sea, and by sea he may come forth of it: but 1 for variety's sake went in by sea, and out by land. Now men may object, how can a man go into a mine, the entrance of it being into the sea, but that the sea will follow him, and so drown the mine? To which objection thus I answer; that at low water mark, the sea being ebbed away, and a great part of the sand bare; upon this same sand, being mixed with rocks and crags, did the master of this great work build a round circular frame of stone, very thick, strong, and joined together with glutinous or bituminous matter, so high withal that the 


\section{EARLY PROSE AND POETICAL WORKS.}

sea at the highest flood, or the greatest rage of storm or tempest, can neither dissolve the stones so well compacted in the building or yet overflow the height of it. Within this round frame, at all adventures, he did set workmen to dig with mattocks, pickaxes, and other instruments fit for such purposes. They did dig forty feet down right into and through a rock. At last they found that which they expected, which was sea coal, they following the vein of the mine, did dig forward still : so that in the space of eight and twenty, or nine and twenty years, they have digged more than an English mile under the sea, so that when men are at work below, an hundred of the greatest ships in Britain may sail over their heads. Besides, the mine is most artificially cut like an arch or a vault, all that great length, with many nooks and byeways: and it is so made, that a man may walk upright in the most places, both in and out. Many poor people are there set on work, which otherwise through the want of employment would perish. But when I had seen the mine, and was come forth of it again; after my thanks given to Sir George Bruce, I told him that if the plotters of the Powder Treason in England had seen this mine, that they, perhaps, would have attempted to have left the Parliament House, and have undermined the Thames, and so to have blown up the barges and wherries, wherein the King, and all the estates of our kingdom were. Moreover, I said, that I could afford to turn tapster at London, so that I had but one quarter of a mile of his mine to make me a cellar, to keep beer and bottled ale

in. But leaving these jests in prose, I will relate a few

verses that I made merrily of this
mine.

I THAT have wasted, months, weeks, days, and hours In viewing kingdoms, countries, towns, and towers, Without all measure, measuring many paces, And with my pen describing many places, 
With few additions of mine own devising, Because I have a smack of Coryatizing, Our Mandeville, Primaleon, Don Quixote, Great Amadis, or Huon, travelled not As I have done, or been where I have been, Or heard and seen, what I have heard and seen ; Nor Britain's Odeombe, Zany brave Ulysses, In all his ambling, saw the like as this is. I was in, would I could describe it well, A dark, light, pleasant, profitable hell, And as by water I was wafted in, I thought that I in Charon's boat had been, But being at the entrance landed thus, Three men there, instead of Cerboras, Convey'd me in, in each one hand a light To guide us in that vault of endless night, There young and old with glim'ring candles burning Dig, delve, and labour, turning and returning, Some in a hole with baskets and with bags, Resembling furies, or infernal hags :

There one like Tantalus feeding, and there one, Like Sisyphus he rolls the restless stone. Yet all I saw was pleasure mixed with profit, Which proved it to be no tormenting Tophet: For in this honest, worthy, harmless hell, There ne'er did any damned devil dwell; And th' owner of it gains by 't more true glory, Than Rome doth by fantastic Purgatory. A long mile thus I passed,.down, down, steep, steep, In deepness far more deep, than Neptune's deep, Whilst o'er my head, in fourfold stories high, Was earth, and sea, and air, and sun, and sky: That had I died in that Cimmerian room, Four elements had covered o'er my tomb: Thus farther than the bottom did I go, And many Englishmen have not done so: Where mounting porpoises, and mountain whales, And regiments of fish with fins and scales, "Twixt me and heaven did freely glide and slide, And where great ships may at an anchor ride: 


\section{6 \\ EARLY PROSE AND POETICAL WORKS.}

Thus in by sea, and out by land I past,

And took my leave of gocd Sir George at last.

The sea at certain places doth leak, or soak into the mine, which by the industry of Sir George Bruce, is all conveyed to one well near the land: where he hath a derice like a horse-mill, that with three horses and a great chain of iron, going downward many fathoms, with thirty-six buckets fastened to the chain, of the which eighteen go down still to be filled, and eighteen ascend up to be emptied, which do empty themselves, without any man's labour, into a trough that conveys the water into the sea again; by which means he saves his mine, which otherwise would be destroyed with the sea, besides he doth make every week ninety or a hundred tons of salt, which doth serve most part of Scotland, some he sends into England, and very much into Germany : all which shows the painful industry with God's blessing to such worthy endeavours: I must with many thanks remember his courtesy to me, and lastly how he sent his man to guide me ten miles on the way to Stirling, where by the way I saw the outside of a fair and stately house called Allaway, belonging to the Earl of Mar, which by reason that his honour was not there, I past by and went to Stirling, where I was entertained and lodged at one Master John Archibalds, where all my want was that I wanted room to contain half the good cheer that I might have had there! he had me into the castle, which in few words I do compare to Windsor for situation, much more than Windsor in strength, and somewhat less in great-. ness: yet I dare affirm that his Majesty hath not such another hall to any honse that he hath neither in England or Scotland, except Westminster Hall, which is now no dwelling hall for a prince, being long since metamorphosed into a house for the law and the profits.

'This goodly hall was built by King James the Fourth, that married King Henry the Eight's sister, and after was slain at Flodden field; but it surpasses all the halls for dwelling houses that ever I saw, for length, breadth, height and strength of bnilding, the castle is built upon a 
rock very lofty, and much beyond Edinburgh Castle in state and magnificence, and not "much inferior to it in strength, the rooms of it are lofty, with carved works on the ceilings, the doors of each room being so high, that a man may ride upright on horseback, into any chamber or lodging. There is also a goodly fair chapel, with cellars, stables, and all other necessary offices, all very stately and befitting the majesty of a king.

From Stirling I rode to Saint Johnstone, a fine town it is, but it is much decayed, by reason of the want of his Majesty's yearly coming to lindge there. There I lodged one night at an irm, the goodman of the house his name being Patrick Pitcaime, where my entertainment wass with good cheer, gond lodsing, all too good to a bad weary gnest. Mine host told me that the Earl of Mar, and Sir William Murray of Abercairney were gone to the great hunting to the Brae of Mar; but if I marle histe I might perhaps find them at a town called Brekin, or Brechin, two and thirty miles from Sinint Johnstone, whereupon I took a guide to Brechin the next day, but before I came, my lord was gone from thence fom days.

Then I tork another guide, which brought me such strange ways over mountains and rocks, that I think my horse never went the like; and I am sure I never saw any ways that might fellow them. I did go through a country called Glen Esk, where passing by the sile of a hill, so steep as the ridge of a honse, where the way was rocky, and not above a yard broad in some places, so fearful and horrid it was to look down into the bottom, for if either horse or man had slipped, he harl fallen without recovery, a grood mile downight; but I thank fod, at night I came to a lndging in the Laird of Edzell's land, where I lay at an Irish homse, the folks not beingr able to speak scarce any English, but I supped and wernt to bed, where I had not laid long, but I was enforced tor rise, I was so stung with Irish musquitoes, a creature that hath six legs, and lives like a monster altogether up'n man's flesh, they do inhabit and breed most in sluttish houses, and this house was none of the cleanest, the beast is much like a louse in England, both in shape and nature; in a 


\section{EARLY PROSE AND POETICAL WORKS.}

word, they were to me the A. and the Z., the prologue and the epilogue, the first and the last that I had in all my travels from Edinburgh: and had not this Highland Irish house belped me at a pinch, I should bave sworn that all Scotland had not been so kind as to have bestowed a louse upon me: but with a shift that I had, I shifted off my cannibals, and was never more troubled with them.

The next day I travelled over an exceeding high mountain, called Mount Skene, where I found the valley very warm before I went up it; but when I came to the top of it, my teeth began to dance in my head with cold, like Virginal's jacks; and withal, a most familiar mist embraced me round, that I could not see thrice my length any way: withal, it yielded so friendly a dew, that did moisten through all my clothes: where the old proverb of a Scottish mist was verified, in wetting me to the skin. Up and down, I think this hill is six miles, the way so uneven, stony, and full of bogs, quagmires, and long beath, that a dog with three legs will out-run a horse with four; for do what we could, we were four hours before we could pass it.

Thus with extreme travel, ascending and descending, mounting and alighting, I came at night to the place where I would be, in the Brae of Mar, which is a large county, all composed of such mountains, that Shooter's Hill, Gad's Hill, Highgate Hill, Hampstead Hill, Birdlip Hill, or Malvern's Hills, are but mole-hills in comparison, or like a liver, or a gizard under a capon's wing, in respect of the altitude of their tops, or perpendicularity of their bottoms. 'There I saw Mount Ben Aren, with a furred mist upon his snowy head instead of a nightcap : for you must understand, that the oldest man alive never saw but the snow was on the top of divers of those hills, both in summer, as well as in winter. There did I find the truly Noble and Right Honourable Lords John Erskine, Earl of Mar, James Stuart, Earl of Murray, George Gordon, Earl of Enzie, son and heir to the Marquess of Huntly, James Erskine, Earl of Buchan, and John Lord Erskine; son and heir to the Earl of Mar, and their Countesses, with 
my much honoured and my best assured and approved friend, Sir William Murray, Knight of Abercairney, and bundred of others, knights, esquires, and their followers ; all and every man in general in one habit, as if Lycurgus had been there and made laws of equality. For once in the year, which is the whole month of August, and sometimes part of September, many of the nobility and gentry of the kingdom, for their pleasure, do come into these Highland countries to hunt, where they do conform themselves to the habit of the Highland men, who for the most part speak nothing but Irish; and in former time were those people which were called the Red-shanks. Their habit is shoes with but one sole apiece; stocking, which they call short hose, made of a warm stuff of divers colours, which they call tartan: as for breeches, many of them, nor their forefathers never wore any, but a jerkin of the same stuff that their hose is of, their garter's being bands or wreaths of hay or straw, with a plaid about their shoulders, which is a mantle of divers colours, of much finer and lighter stuff than their hose, with blue flat caps on their heads, a handkerchief knit with two knots about their neck; and thus are they attired. Now their weapons are long bows and forked arrows, swords and targets, harquebusses, muskets, dirks, and Lochaber axes. With these arms I found many of them armed for the hunting. As for their attire, any man of what degree soever that comes amongst them, must not disdain to wear it; for if they do, then they will disdain to hunt, or willingly to bring in their dogs: but if men be kind unto them, and be in their habit; then are they conquered with kindness, and the sport will be plentiful. This was the reason that I found so many noblemen and gentlemen in those shapes. But to proceed to the hunting.

My good Lord of Mar having put me into that shape, I rode with him from his house, where I saw the ruins of an old castle, called the castle of Kindroghit [Castledown]. It was built by King Malcolm Canmore, for a hunting house, who reigned in Scotland when Edward the Confessor, Harold, and Norman William reigned in 


\section{EARLY PROSE AND POETICAL WORKS.}

Fngland. I speak of it, because it was the last house that I saw in those parts; for I was the space of twelve days after, before I saw either house, corn field, or habitation for any creature, but deer, wild horses, wolves and such like creatures, which made me doubt that I should never have seen a house again.

Thus the first day we travelled eight miles, where there were small cottages built on purpose to lodge in, which they call Lonchards, I thank my good Lord Erskine, he commanded that I should always be lodged in his lodging, the kitchen being always on the side of a bank, many kettles and pots boiling, and many spits turning and winding, with great variety of cheer; as venison baked, sodden, roast, and stewed beef, mutton, goats, kid, hares, fresh salmon, pigeous, hens, capons, chickens, partridge, moor-coots, heath-cocks, capercailzies, and termagants [ptarmigans]; good ale, sack, white, and claret, tent, or Alicante, with most potent Aquavitæ.

All these, and more than these we had continually, in superfluous abundance, caught by falconer's, fowlers, fishers, and brought by my lord's tenants and purveyors to victual our camp, which consisted of fourteen or fitteen hundred men and horses. 'The manner of the hunting is this: five or six hundred men do rise early in the morning, and they do disperse themselves divers ways, and seven, eight, or ten miles compass, they do bring or chase in the deer in many herds, two, three, or four hundred in a herd, to such or such a place, as the Nobleman shall appoint them; then when day is come, the Lords and gentlemen of their companies, do ride or go to the said places, sometimes wading up to their middles through bournes and rivers. And then, they being come to the place, do lie down on the ground, till those foresaid scouts, which are called the Tinchel, do bring down the deer; but as the proverb says of a bad cook, so these Tinchel-men do lick their o.wn fingers; for besides their bows and arrows, which they carry with them, we can hear now and then a harquebuss or a musket $g^{\prime \prime}$ off, which they do seldom discharge in vain. Then after we had stayed there three hours cr thereabouts, we 


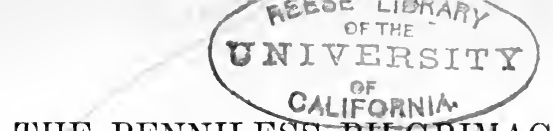

THE PENNILESS PIEGRIMAGE.

might perceive the deer appear on the hills round about us, their heads making a show, like a wood, which being followed close by the Tinchel, are chased down into the valley where we lay: then all the valley on each side being waylaid with a hundred couple of strong Irish greyhounds, they are let loose as the occasion serves upon the herd of deer, so that with dogs, guns, arrows, dirks, and daggers, in the space of two hours, fourscore fat deer were slain, which after are disposed of some one way, and some another, twenty and thirty miles, and more than enough left for us to make merry withal at our rendezvous. I liked the sport so well, that I made these two sonnets following.

WHY should I waste invention to indite,

Ovidian fictions, or Olympian games?

My misty Muse enlightened with more light,

To a more noble pitch her aim she frames.

I must relate to my great Master JAMES,

'The Caledonian annual peaceful war;

How noble minds do eternize their fames, By martial meeting in the Brae of Mar :

How thousand gallant spirits came near and far, With swords and targets, arrows, bows, and guns, That all the troop to men of judgment, are The God of Wars great never conquered sons, The sport is manly, yet none bleed but beasts, And last the victor on the vanquished feasts.

IF sport like this can on the mountains be, Where Phobus flames can never melt the snow;

Then let who list delight in vales below, Sky-kissing mountains pleasure are for me: What braver object can man's eyesight see, Than noble, worshipful, and worthy wights, As if they were prepared for sundry fights,

Yet all in sweet society agree?

Through heather, moss, 'mongst frogs and bogs, and fogs, 'Mongst craggy cliffs, and thunder-battered hills, Hares, hinds, bucks, roes, are chased by men and dogs, Where two hours hunting fourscore fat deer kills. 
Lowland, your sports are low as is your seat, The Highland games and minds, are high and great.

Being come to our lodgings, there was such baking, boiling, roasting, and stewing, as if Cook Ruffian had been there to have scalded the devil in his feathers: and after supper a fire of fir-wood as high as an indifferent May-pole; for I assure you, that the Earl of Mar will give any man that is his friend, for thanks, as many fir trees, that are as good as any ship's masts in England, as are worth if they were in any place near the 'Thames, or any other portable river, the best earldom in England or Scotland either. For I dare affirm, he "hath as many growing there, as would serve for masts, from this time to the end of the world, for all the ships, caracks, hoys, galleys, boats, drumlers, barks, and watercrafts, that are now, or can be in the world these forty years.

This sounds like a lie to an unbeliever; but I and many thousands do know that I speak within the compass of truth : for indeed, the more is the pity, they do grow so far from any passage of water, and withal in such rocky mountains, that no way to convey them is possible to be passable, either with boat, horse, or cart.

Thus having spent certain days in hunting in the Brae of Mar, we went to the next county called Badenoch, belonging to the Earl of Enzie, where having such sport and entertainment as we formerly had; after four or five days pastime, we took leave of hunting for that year; and took our journey toward a strong house of the Earl's, called Ruthven in Badenoch, where my Lord of Enzie and his noble Countess, being daughter to the Earl of Argyle, did give us most noble welcome three days.

From thence we went to a place called Balloch Castle, a fair and stately house, a worthy gentleman being the owner of it, called the Laird of Grant; his wife being a gentlewoman honourably descended, being sister to the right Honourable Earl of Athol, and to Sir Patrick Murray, Knight; she being both inwardly and outwardly plentifully adorned with the gifts of grace and nature: so that our cheer was more than sufficient; and yet much less than they could afford us. There stayed there four 
days, four Earls, one Lord, divers Knights and Gentlemen, and their servants, footmen and horses; and every meal four long tables furnished with all varieties; our first and second course being three score dishes at one board; and after that always a banquet; and there if I had not forsworn wine till I came to Edinburgh I think I had there drunk my last.

The fifth day with much ado we gate from thence to Tarnaway, a goodly house of the Earl of Murrays, where that Right Honourable Lord and his Lady did welcome us four days more. There was good cheer in all variety, with somewhat more than plenty for advantage; for indeed the County of Murray is the most pleasantest and plentiful country in all Scotland; being plain land, that a coach may be driven more than four and thirty miles one way in it, alongst by the sea-coast.

From thence I went to Elgin in Murray, an ancient City, where there stood a fair and beautiful church with three steeples, the walls of it and the steeples all yet standing; but the roofs, windows, and many marble monuments and tombs of honourable and worthy personages all broken and defaced; this was done in the time when ruin bare rule, and Knox knocked down churches.

From Elgin we went to the Bishop of Murray his house which is called Spiny, or Spinay; a Reverend Gentleman he is, of the noble name of Douglas, where we were very well welcomed, as befitted the honour of himself and his guests.

From thence we departed to the Lord Marquess of Huntlys to a sumptuous house of his, named the Bog of Geethe, where our entertainment was like himself; free, bountiful and honourable. There, after two days stay, with much entreaty and earnest suit, I gate leave of the Lords to depart towards Edinburgh : the Noble Marquess, the Earl of Mar, Murray, Enzie, Buchan, and the Lord Erskine; all these, I thank them, gave me gold to defray my charges in my journey.

So after five and thirty days hunting and travel I returning, past by another stately mansion of the Marquesses, called Stroboggy, and so over Carny mount to 


\section{EARLY PROSE AND POETICAL WORKS.}

Brechin, where a wench that was born deaf and dumb came into my chamber at midnight, I being asleep, and she opening the bed, would fain have lodged with me: but had I been a Sardanapulus, or a Heliogabulus, I think that either the great travel over the mountains had tamed me; or if not, her beauty could never have moved me. The best parts of her were, that her breath was as sweet as sugar-candian, being very well shouldered beneath the waste; and as my hostess told me the next morning, that she had changed her maiden-head for the price of a bastard not long before. But howsoever, she made such a hideous noise, that I started out of my sleep, and thought that the devil had been there: but I no sooner knew who it was, but I arose, and thrust my dumb beast out of my chamber; and for want of a lock or a latch, I staked up my door with a great chair.

Thus having escaped one of the seven deadly sins as at Brechin, I departed from thence to a town called Forfor; and from thence to Dundee, and so to Kinghorn, Burntisland, and so to Edinburgh, where I stayed eight days, to recover myself of falls and bruises, which I received in my travel in the Highland mountainous hunting. Great welcome I had showed me all my stay at Edinburgh, by many worthy gentlemen, namely, old Master George Todrigg, Master Henry Livingston, Master James Henderson, Master John Maxwell, and a number of others, who suffered me to want no wine or good cheer, as may be imagined.

Now the day before I came from Edinburgh, I went to Leith, where I found my long approved and assured good friend Master Benjamin Jonson, at one Master John Stuart's house; I thank him for his great kindness towards me: for at my taking leave of him, he gave me a piece of gold of two and twenty shillings to drink his health in England. And withal, willed me to remember his kind commendations to all his friends. So with a friendly farewell, I left him as well, as I hope never to see him in a worse estate: for he is amongst noblemen and gentlemen that know his true worth, and their own honours, where, with much respective love he is worthily entertained. 
So leaving Leith I returned to Edinburgh, and within the port or gate, called the Nether-Bow, I discharged my pockets of all the money I had; and as I came pennyless within the walls of that city at my first coming thither; so now at my departing from thence, I came moneyless. out of it again ; having in company to convey me out, certain gentlemen, amongst the which Master James Acherson, Laird of Gasford, a gentleman that brought me to his house, where with great entertainment he and his good wife did welcome me.

On the morrow he sent one of his men to bring me to a place called Adam, to Master John Acmootye his house, one of the Grooms of his Majesty's bed-chamber; where with him and his two brethren, Master Alexinder, and Master James Acmootye, I found both cheer and welcome, not inferior to any that I had had in any former place.

Amongst our viands that we had there, I must not forget the Solean Goose, a most delicate fowl, which breeds in great abundance in a little rock called the Bass, which stands two miles into the sea. It is very good flesh, but it is eaten in the form as we eat orsters, standing at a side-board, a little before dinner, unsanctified without grace; and after it is eaten, it must be well liquored with two or three good rouses of sherry or canary sack. The lord or owner of the Bass duth profit at the least two hundred pound yearly by those geese; the Bass itself being of a great height, and near three quarters of a mile in compass, all fully replenished with wild fowl, having but one small entrance into it, with a house, a garden, and a chapel in it; and on the top. of it a well of pure fresh water.

From Adam, Master John and Master James Acmootye went to the town of Dunbar with me, where ten Scottish pints of wine were consumed, and brought to nothing for a farewell; there at Master James Baylies house I took leave, and Master James Acmootye coming for England, said, that if I would ride with, that neither I nor my horse should want betwixt that place and London. Now I having no money nor means for travel, began at once to 


\section{EARLY PROSE AND POETICAL WORKS.}

examine my manners and my want : at last my want persuaded my manners to accept of this worthy gentleman's undeserved courtesy. So that night he brought me to a place called Cockburnspath, where we lodged at an inn, the like of which I dare say, is not in any of his Majesty's dominions. And for to show my thankfulness to Master William Arnot and his wife, the owners thereof, I must explain their bountiful entertainment of guests, which is this :

Suppose ten, fifteen, or twenty men and horses come to lodge at their house, the men shall have flesh, tame and wild fowl, fish with all variety of good cheer, good lodging, and welcome; and the horses shall want neither hay or provender; and at the morning at their departure, the reckoning is just nothing. This is this worthy gentleman's use, his chief delight being only to give strangers entertainment gratis; and I am sure, that in Scotlaud beyond Ediuburgh, I have been at houses like castles for building; the master of the house his beaver being his blue bonnet, one that will wear no other shirts, but of the flax that grows on his own ground, and of his wife's, daughters', or servants' spinning; that hath his stockings, hose, and jerkin of the wool of his own sheep's backs; that never by his pride of apparel caused mercer, draper, silk-man, embroiderer, or haberdasher to break and turn bankrupt. And yet this plain home-spun fellow keeps and maintains thirty, forty, fifty, servants, or perhaps, more, every day relieving three or fourscore poor people at his gate; and besides all this, can give noble entertainment for four or five days together to five or six earls and lords, besides knights, gentlemen, and their followers, if they be three or four hundred men, and horse of them, where they shall not only feed but feast, and not feast but banquet, this is a man that desires to know nothing so much, as his duty to God and his King, whose greatest cares are to practise the works of piety, charity, and hospitality; he never studies the consuming art of fashionless fashions, he never tries his strength to bear four or five hundred acres on his back at once, his legs are always at liberty, not being fettered with golden 
garters, and manacled with artificial roses, whose weight, sometime, is the last reliques of some decayed Lordship. Many of these worthy housekeepers there are in Scotland, amongst some of them I was entertained; from whence I did truly gather these aforesaid observations.

So leaving Cockburnspath, we rode to Berwick, where the worthy old Soldier and ancient Knight, Sir William Bowyer, made me welcome, but contrary to his will, we lodged at an Inn, where Master James Acmootye paid all charges: but at Berwick there was a grevious chance happened, which I think not fit the relation to be omitted.

In the river of 'Tweed, which runs by Berwick, are taken by fisherman that dwell there, infinite numbers of fresh salmons, so that many househoulds and families are relieved by the profit of that fishing; but, how long since I know not, there was an order that no man or boy whatsoever should fish upon a Sunday: this order continued long amongst them, till some eight or nine weeks before Michaelmas last, on a Sunday, the salmons played in such great abundance in the river, that some of the fishermen, contrary to God's law and their own order, took boats and nets and fished, and caught near three hundred salmons; but from that time until Michaelmas day that I was there, which was nine weeks, and heard the report of it, and saw the poor people's miserable lamentations, they had not seen one salmon in the river; and some of them were in despair that they should never see any more there ; affirming it to be God's judgment upon them for the profanation of the Sabbath.

The thirtieth of September we rode from Berwick to Belford, from Belford to Alnwick, the next day from Alnwick to Newcastle, where I found the noble Knight, Sir Henry Witherington, who, because I would have no gold nor silver, gave me a bay mare, in requital of a loaf of bread that I had given him two and twenty years before, at the Island of Flores, of the which I have spoken before. I overtook at Newcastle a great many of my worthy friends, which were all coming for London, namely, Master Robert Hay, and Master David Drummond, where I was welcomed at Master Nicholas Tem- 
pest's house. From Newcastle I rode with those gentlemen to Durham, to Darlington, to Northallerton, and to Topcliffe in Yorkshire, where I took my leave of them, and would needs try my pennyless fortunes by myself, and see the city of York, where I was lodged at my right worshipful good friend, Master Doctor Hudson, one of his Majesty's chaplains, who went with me, and shewed me the goodly Minster Church there, and the most admirable, rare-wrought, unfellowed chapter house.

From York I rode to Doncaster, where my horses were well fed at the Bear, but myself found out the honorable knight, Sir Robert Anstruther at his father-in-law's, the truly noble Sir Robert Swift's house, he being then High Sheriff of Yorkshire, where with their good ladies, and the right Honourable the Lord Sanquhar, I was stayed two nights and one day, Sir Robert Anstruther, I thank him, not only paying for my two horses' meat, but at my departure, he gave me a letter to Newark upon Trent, twenty-eight miles in my way, where Master George Atkinson, mine host, made me as welcome, as if I had been a French Lord, and what was to be paid, as I called for nothing, I paid as much; and left the reckoning with many thanks to Sir Robert Anstruther.

So leaving Newark, with another gentleman that overtook me, we came at night to Stamford, to the sign of the Virginity, or the Maidenhead, where I delivered a letter from the Lord Sanquhar; which caused Master Bates and his wife, being the master and mistress of the house, to make me and the gentleman that was with me great cheer for nothing.

From Stamford the next day we rode to Huntington, where we lodged at the Postmaster's house, at the sign of the Crown; his name is Riggs. He was informed who I was, and wherefore I undertook this my pennyless progress; wherefore he came up to our chamber, and supped with us, and very bountifully called for three. quarts of wine and sugar, and four jugs of beer. He did drink and begin healths like a horse-leech and swallowed down his cups without feeling, as if he had had the dropsy, or nine pound of sponge in his maw. In a word, 
as he is a post, he drank post, striving and calling by all means to make the reckoning great, or to make us men of great reckoning. But in his payment he was tired like a jade, leaving the gentleman that was with me to discharge the terrible shot, or else one of my horses must have lain in pawn for his superfluous calling, and unmannerly intrusion.

But leaving him, I left Huntington, and rode on the Sunday to Puckeridge, where Master Holland at the Falcon, mine old acquaintance, and my loving and ancient host gave me, my friend, my man, and our horses, excellent cheer and welcome, and I paid him with not a penny of money.

The next day I came to London, and obscurely coming within Moorgate, I went to a house and borrowed money: and so I stole back again to Islington, to the sign of the Maidenhead, staying till Wednesday, that my friends came to meet me, who knew no other, but that Wednesday was my. first coming; where with all love I was entertained with much good cheer: and after supper we had a play of the Life and Death of Guy of Warwick, played by the Right Honourable the Earl of Derby his men. And so on the Thursday morning being the fifteenth of October, I came home to my house in London.

\section{THE EPILOGUE TO ALL MY ADVENTURERS AND OTHERS.}

THus did I neither spend, or beg, or ask, By any course, direct or indirectly :

But in each tittle I performed my task, According to my bill most circumspectly. I vow to God, I have done Scotland wrong, - And, justly, against me it may bring an action, I have not given it that right which doth belong, For which I am half guilty of detraction: Yet had I wrote all things that there I saw, Misjudging censures would suppose I flatter, 
And so my name I should in question draw, Where asses bray, and prattling pies do chatter: Yet, armed with truth, I publish with my pen, That there the Almighty doth his blessings heap, In such abundant food for beasts and men; That I ne'er saw more plenty or more cheap. Thus what mine eyes did see, I do believe; And what I do believe, I know is true: And what is true unto your hands I give, That what I give, may be believed of you. But as for him that says I lie or dote, I do return, and turn the lie in's throat. Thus gentleman, amongst you take my ware, You share my thanks, and I your moneys share. 


\section{A KICKSEY WINSEY}

OR

\section{A LERRY COME-TWANG}

WHEREIN

John Taylor hath satyrically suited $800^{\circ}$ of his bad debtors that will not pay him for his return of his journey from Scotland.

My debtors, like seven eels with slipp'rie tails, One sort I catch, six slips away and fails. 
To

The worthy gentleman, Master Raphe Wormaighton, the hopeful son of his noble father, Raphe Wormlaighton, Esq.

- Gray's Inn' Wormlaighton, a true scholar, right With love and thanks, you paid me at first sight; Your worthy father gave me what was due, And for his love, I give my thanks to you.

To

The Mirror of Good Fellowship, the pattern of true friendship, and the only nonparallel of jovial entertainment, Master George Hilton, at the sign of the Horse-shoe, at Daventry, J. Taylor wisheth daily increase of good guests, true payments, heart's content in this life, and afterward as much happiness as his soul can desire.

KIND Sir, I have seen oftentimes men offering to snuff a candle, have against their wills put it clean out; and an unskilful Chirurgeon taking a small green wound in hand, hath brought it to an old ulcer. I would be loth, for my part, to imitate either of these examples ; for my intent is, confession of the wrong I did you, and an endeavour to make amends. I do confess that I did you wrong in print, in my book of my travels to Scotland, and now in print, I do make you a public satisfaction; for, I protest to God, that I have heard so much good report of you, that I am double sorry that I was so mistaken, and that I have been so long time before I have printed my recantation. It was your tapster's want of wit, and my want of discretion, that was the grounds of my too much credulity and temerity. For his part I wish him no more harm, but that chalk may be his best payments, thunder may sour his hogsheads, rats may gnaw out his spigots at midnight, and himself to commit his wit to the keeping of a fool while he lives; and your ostlers for gaping so greedily like gudgeons upon me, I pray that they may every day mourn in litter 


\section{A KICKSEY WINCEY.}

and horse dung. But these are but jests by the way: for as many as know you, have told me, that if you had been at home, my entertainment had been better. If it had been so, it had been more than you owed me, and more than I at that time could have requited: but I would have stretched my wit upon the terters of invention, in the praise of inns and inn-keepers, I would have put the forgetful world in mind of the good service that Rahab the innkeeper did at Jericho, in hiding and preserving the spies that were sent by Caleb and Joshua; I would have made the oblivious loggerheaded Age remember that the Redeemer of the world did grace an inn with his blessed birth: what place then but an inn was the High Court of Heaven and earth, the residence and lodging of the immortal King, of never-ending eternity? This and more I would have done, but what is passed cannot be recalled, and it is too late to put old onittings to new committings. And so, my noble and thrice worthy host of hosts, I omit not to commit you and yours to the protection of the Lord of Hosts, desiring you to take this merry Pamphlet in good part, or in earnest of my better amends, and as a qualifier of your just anger.

\section{THE WHY AND THE WHEREFORE.}

I Have published this Pamphlet, to let my rich debtors understand, that as often as I meet them, I do look that they should pay me: and although I am shamefaced in not asking my due, yet I would not have them shameless in detaining it from me, because the sums are but small, and very easy for them, in general, to pay, and would do me a particular good to receive.

Secondly, I have sent this into the world, to inform some, that through their want do shun and avoid my sight and company, that they are much deceived in my disposition; for I ever did esteem an honest heart and a willing mind, as well as their performances.

Thirdly, thère are some great men, who by reason of their extraordinary employments, my small acquaintance, and less means of access unto them, with my want of 


\section{EARLY PROSE AND POETICAL WORKS.}

impudency, and their men's want of courtesy to inform them; all these are lets and demurs, against my satisfaction.

Lastly, the daily abuses that I have concerning the book of my travels, wherein I am accused for lies, and falsifications; but I do and ever will steadfastly stand to the truth of every tittle of it, except the abuse that I did to Master Hilton at Daventry, and that was not done on known malice neither, but on blind ignorant information: and there is a second edition of my books of travels coming forth, wherein I will satirize, cauterize, and stigmatize all the whole kennel of curs that dare maliciously snarl against manifest, apparent, and well known truths. In the mean space, you that are my debtors, if you please to pay me, you shall therein put yourselves out of a bad number amongst which you yet are placed: if you will not pay me, take this bone to gnaw upon, that I do hope to be ever better furnished with money, than you shall be with honesty.

\section{A TABLE OF THE GENERAL HEADS,}

Containing Seven Parts.

1 Those that have paid.

2 Those that would pay if they could.

3 Those that walk invisible, and are not to be found.

4 Those that say they will pay, who knows when?

5 Those that are dead.

6 Those that are fled.

7 'Those roarers that can pay, and will not.

Those that do ever mean to pay,

Nothing at all this book doth say;

To such my satire talketh still

As have not paid, nor ever will. 


\section{A KICKSEY WINSEY:}

or,

\section{A LERRY COME-TWANG;}

Wherein John Taylor hath satirically suited 800 of his bad debtors, that will not pay him for his return of his Journey from Scotland.

\section{My thanks to those that have paid.}

You worthy worthies, of that liberal tribe, Who freely gave your words, or did subscribe : And were not itched with the vain-glorious worm, To write and lie, but promise and perform, Black swans of Britain, I protest you are, And seem, to me, each one a blazing star; For this inconstant age so few affords Of men, whose deeds do counterpoise their words, That finding one, methinks I see a wonder, More than December's fruit, or winter's thunder;

Ingratitude, I hold a vice so vile, That I could ne'er endure it a breathing while: And therefore ere I'll prove a thankless jade, Time in his course shall run quite retrograde; Yea, everything shall hate his proper kind, Before I'll harbour an ungrateful mind: And still I vow to quit you in some part, With my best wishes, and a thankful heart: So much to you, my Muse hath sung or said, Whose loving bounties hath the sculler paid.

2. Those that would pay if they could. AND as for you that would pay if you could, I thank you, though you do not as you should, You promised fair, and wrote as free as any, But time hath altered since, the casie with many; Your monies, like low tides, are ebbed too low, And when, 'tis lowest, 'twill begin to flow. To seek a breech from breechless men, 'twere vain, And fruitless labour would requit my pain : 
It were no charity (as I suppose)

To bid one wipe his nose, that wants a nose; And sure my conscience would be less than little, To enrich myself, by robbing of the spittle:

No, honest friends (to end this vain dispute) Your barren states may spring, and bring forth fruit; Your wills are good, and whilst I keep your bills, Instead of payment I accept good wills;

On hope and expectation I will feed, And take your good endeavours for:the deed; Praying that crosses in your minds may cease, And crosses in your purses may increase.

3. Those that are hard for me to find, and being found, were better lost.

ANother sort of debtors are behind, Some I know not, and some I cannot find: And some of them lie here and there, by spirts, Shifting their lodgings oftener than their shirts. Perchance I hear where one of these men lies, And in the morning up betimes I rise, And find in Shoreditch where he lodged a night; But he to Westminster hath ta'en his flight. Some two days after thither do I trot, And find his lodging, but yet find him not, For he the night before, as people tell, Hath ta'en a chamber about Clerken well. Thither go I, and make a privy search, Whilst he's in Southwark, near St. George's Church. A pox upon him, all this while think I, Shall I ne'er find out where my youth doth lie? And having sought him many a weary bout, At last, perhaps I find his chamber out: But theri the gentleman is fast in bed, And rest hath seized upon his running head: $\mathrm{He}$ hath took cold with going late by water, Or sat up late at ace, deuse, tray, andcater [quatre] That with a sink [cinq] of fifty pieces price, He sleeps till noon before his worship rise. At last he wakes; his man informs him straight, 
That I at door do on his pleasure wait; Perhaps I am requested to come near, And drink a cup of either ale or beer, -Whilst sucking English fire, and Indian vapour, At last I greet him with my bill of paper : Well John, quoth he, this hand I know is mine, But I this day do purpose to go dine At the Half Moon in Milk-street, prithee come, And there we'll drink, and pay this petty sum. Thus many a street by me recrossed and crossed, - $\mathrm{I}$ in and out, and too and fro, am tossed, And spend my time and coin to find one out, Which having found, rewards me with a flout. In this base fashion, or such like as this, To me their scurvy daily dealing is ; As one's in study, the other's deep in talk, Another's in his garden gone to walk:

One's in the barber's suds, and cannot see, Till chin and chaps are made a Roman T: And for his making thus a gull of me, I wish his cut may be the Grecian P. These men can kiss their claws, with Jack, how is't? And take and shake me kindly by the fist, And put me off with dilatory cogs, And swear and lie, worse than so many dogs, Protesting they are glad I am returned, When they'd be gladder I were hanged or burned. Some of their pockets are oft stored with chink, Which they had rather waste on drabs, dice, drink, 'Than a small petty sum to me to pav, Although I meet them every other day; For which to ease my mind to their disgrace, I must, perforce, in print proclaim them base; And if they pay me not, unto their shames, I'll print their trades, their dwellings, and their names, That boys shall hiss them as they walk along, Whilst they shall stink, and do their breeches wrong: Pay then, delay not, but with speed disburse, Or if you will, try but who'll have the worse. 


\section{Those that will and do daily pay me in drink and smoke.}

A FOURTH crew I must drop from out my quill, Are some that have not paid, yet say they will: And their remembrance gives my muddy mood, -More joy than of those that will ne'er be good. These fellows my sharp Muse shall lash but soft, Because I meet them to their charges oft, Where at the tavern, with free frolic hearts, They welcome me with pottles, pint's, and quarts; And they, at times, will spend like honest men, Twelve shillings, rather than pay five or ten. These I do never seek from place to place, These make me not to run the wild goose chase; These do from day to day not put me off, And in the end reward me with a scoff. And for their kindness, let them take their leisure, To pay or not pay, let them take their pleasure. Let them no worser than they are, still prove: Their powers may chance outdo me, not their love;

I meet them to my peril, and their cost, And so in time there's little will be lost.

Yet the old proverb I would have them know, The horse may starve the whilst the grass doth grow.

\section{Those that are dead.}

A FIFTH sort, God be with them, they are dead, And everyone my quittance under's head: To ask them coin, I know they have it not, And where nought is, there's nothing to be got; I'll never wrong them with invective lines, Nor trouble their good heirs, or their assigns. And some of them, their lives lost to me were, In a large measure of true sorrow dear, As one brave lawyer, whose true honest spirit Doth with the blest celestial souls inherit, He whose grave wisdom gained pre-eminence, To grace and favour with his gracious prince: Adorned with learning, loved, approved, admired, $\mathrm{He}, \mathrm{my}$ true friend, too soon to dust retired. 


\section{A KICKSEY IVINSEY.}

Besides, a number of my worthy friends, To my great loss, death brought unto their ends. Rest, gentle spirits, rest, with eternizing, And may your corpse have all a joyful rising: There's many living, every day I see, Who are more dead than you in pay to me.

\section{Those that are fled.}

A sIxTH, with tongues glib, like the tails of eels, Hath shewed this land and me foul pairs of heels, To Ireland, Belgia, Germany, and France, They are retired to seek some better chance. 'Twas their unhappy inauspicious fate, The Counters, or King Luds unlucky gate; Bonds being broke, the stones in every street, They durst not tread on, lest they burnt their feet; Smoke by the pipe, and ginger by the race, They loved with ale, but never loved the mace. And these men's honesties are like their states, At piteous, woeful, and at low prized rates ; For partly they did know when they did take My books, they could no satisfaction make, And honesty this document doth teach, That man shall never strive above his reach, Yet have they reached, and over-reached me still, To do themselves no good, and me much ill. But, farewell friends, if you again do come, And pay me either all, or none, or some : I look for none, and therefore still delay me, You only do deceive me, if you pay me. Yet that deceit from you were but my due, But I look ne'er to be deceived by you. Your stocks are poor, your creditors are store, Which God increase, and decrease, I implore.

7. Those that are as far from honesty, as a Turk is from true Religion.

SEventhly, and last's a worthy worthless crew, Such as heaven hates, and hell on earth doth spew, And God renounce, and damn them, are their prayers, 
Yet some of these sweet youths are good men's heirs.

But up most tenderly they have been brought, And all their breeding better fed than taught: And now their lives float in damnation's stream, To stab, drab, kill, swill, tear, swear, stare, blaspheme: In imitation worse than devil's apes, Or incubuses thrust in human shapes: As bladders full of other's wind is blown, So self-conceit doth puff them of their own: They deem their wit all other men surpasses, And other men esteem them witless asses. These puckfist cockbrained coxcombs, shallow pated, Are things that by their tailors are created; For they before were simple shapeless worms, Until their makers licked them into forms. 'Tis ignorant idolatry most base, To worship satin Satan, or gold lace, T'adore a velvet varlet, whose repute Stinks odious, but for his perfumed suit. If one of these to serve some Lord doth get, His first task is to swear himself in debt: And having pawned his soul to hell for oaths, He pawns those oaths for newfound fashion clothes. His carcase cased in this borrowed case, Imagines he doth me exceeding grace, If when I meet him, he bestows a nod, Then must I think me highly blest of God; And though no wiser than flat fools they be, A good luck on them, they are too wise for me. They with a courtly trick or a flim-flam, Do nod at me, whilst I the noddy am : One part of gentry they will ne'er forget, And that is, that they ne'er will pay their debt. To take, and to receive, they hold it fit, But to requite, or to restore's no wit. And let them take and keep, but knocks, and pox, And all diseases from Pandora's box. And which of them says that I rave or rail, Let him but pay, and bid me kiss his T. But sure the devil hath taught them many a trick, 
Beyond the numbering of arithmetic.

I meet one, thinking for my due to speak, He with evasions doth my purpose break, And asks what news I hear from France or Spain,

Or where I was in the last shower of rain;

Or when the court removes, or what's a clock, Or where's the wind, or some such windy mock, With such fine scimble, scemble, spitter-spatter, As puts me clean besides the money-matter?

Thus with poor mongrel shifts, with what, where when?

I am abused by these things, like men, And some of them do glory in my want, They being Romists, I a Protestant. Their apostatical injunction saith, To keep their faith with me, is breach of faith : For 'tis a maxim of such Catholics, 'Tis meritorious to plague heretics;

Since it is so, pray pay me but my due, And I will love the cross as well as you. And this much further I would have you know, My shame is more to ask, than yours to owe: I beg of no man, 'tis my own I crave, Nor do I seek it but of them that have; There's no man was enforced against his will, To give his word, or sign unto my bill. And is't not shame, nay, more than shame to hear, That I should be returned above a year, And many rich men's words, and bills have passed, And took of me both books, both first and last, Whilst twice or thrice a week, in every street, I meet those men, and not my money meet. Were they not able me amends to make, My conscience then would sooner give than take: But most of those I mean, are full pursed hinds, Being beggarly in nothing but their minds : Yet sure methinks, if they would do me right, Their minds should be as free to pay, as write. Near threescore pounds, the books I'm sure did cost, Which they have had from me, and I think lost: And had not these men's tongues so forward been, 
Ere I my painful journey did begin,

I could have had good men in meaner raiment, That long ere this, had made me better payment.

I made my journey for no other ends,

But to get money, and to try my friends;

And not a friend I had, for worth or wit

Did take my book, or pass his word, or writ :

But I, with thankfulness, still understood

They took, in hope to give, and do me good.

They took a book worth 12 pence, and were bound

To give a crown, an angel, or a pound,

A noble, piece, or half piece, what they list,

They passed their words, or freely set their fist.

Thus got I sixteen hundred hands and fifty,

Which sum I did suppose was somewhat thrifty ;

And now my youths, with shifts, and tricks, and cavils,

Above eight hundred, play the sharking javels.

I have performed what I undertook,

And that they should keep touch with me I look.

Four thousand, and five hundred books I gave

To many an honest man, and many a knave :

Which books, and my expense to give them out,

A long year seeking this confused rout,

I'm sure it cost me sevenscore pounds and more,

With some suspicion that I went on score.

Besides, above a thousand miles I went, And, though no money, yet much time I spent;

Taking excessive labour, and great pains,

In heat, cold, wet, and dry, with feet and brains :

With tedious toil, making my heart-strings ache,

In hope I should content both give and take,

And in requital now, for all my pain,

I give content still, and get none again.

None, did I say? I'll call that word again,

I meet with some that pay me now and then,

But such a toil I have those men to seek,

And find, perhaps, 2, 3, or 4 a week,

That too too oft, my losings gettings be,

To spend 5 crowns in gathering in of three.

And thus much to the world I dare avow, 


\section{A KICKSEY WINSEY.}

That my oft walks to get my money now,

With my expenses, seeking of the same,

Returning many a night home, tired and lame,

Meeting some thirty, forty in a day,

That sees me, knows me, owes me, yet none pay.

Used and abused thus, both in town and court,

It makes me think my Scottish walk a sport;

I muse of what stuff these men framed be,

Most of them seem mockado unto me,

Some are stand-further off; for they endeavour,

Never to see me, or to pay me never.

When first I saw them, they appeared rash,

And now their promises are worse than trash;

No taffety more changeable than they,

In nothing constant, but no debts to pay.

And therefore let them take it as they will,

I'll canvass them a little with my quill.

To all the world I humbly do appeal,

And let it judge, if well these men do deal,

Or whether for their baseness, 'twere no fitter,

That I should use more gall, and write more bitter?

I wrote this book before, but for this end,

To warn them, and their faults to reprehend;

But if this warning will not serve the turn,

I swear by sweet Satiric Nash his urn,

On every pissing post, their names I'll place

Whilst they past shame, shall shame to show their face;

I'll hail fell Nemesis, from Dis his den,

To aid and guide my sharp revenging pen ;

That fifty Pope's bulls never shall roar louder,

Nor fourscore cannons when men fire their powder.

There's no wound deeper than a pen can give,

It makes men living dead, and dead men live;

It can raise honour drowned in the sea,

And blaze it forth in glory, cap-a-pie.

Why, it can scale the battlements of heaven, And stellify men 'mongst the planets seven: It can make misers, peasants, knaves, and fools The scorn of goodness, and the devil's close stools. Forgot had been the thrice three worthies' names, 
If thrice three Muses had not writ their fames : And if it not with flattery be infected, Good is by it extolled, and bad corrected. Let judgment judge them what mad men are those That dare against a pen themselves oppose, Which, when it likes, can turn them all to loathing, To anything, to nothing, worse than nothing; Yet e'er I went, these men to write did like, And used a pen more nimbly than a pike; And writ their names, as I supposed, more willing, Than valiant soldiers with their pikes are drilling; No paper bill of mine had edge upon it, Till they their hands and names had written on it; And if their judgments be not overseen, They would not fear, the edge is not so keen. Some thousands, and some hundreds by the year Are worth, yet they their piece or half-piece fear ; They on their own bills are afraid to enter, And I upon their pieces dare to venture: But whoso at the bill hath better skill, Give me the piece, and let him take the bill. I have met some that odiously have lied, Who to deceive me, have their names denied. And yet they have good honest Christian names, As Joshua, Richard, Robert, John, and James :

To cheat me with base inhumanity, They have denied their Christianity; A half-piece or a crown, or such a sum, Hath forced them falsify their Christendom : Denying good, ill names with them agree, And they that have ill names, half hanged be, And sure I think, my loss would be but small, If for a quittance they were hanged up all. Of such I am past hope, and they past grace, And hope and grace both past's, a wretched case, It may be that for my offences passed, God hath upon me this disturbance cast: If it be so', I thank his name therefore, Confessing I deserve ten times much more; But as the devil is author of all ill; 


\section{A KICKSEY CALIERENI.}

So ill for ill, on th' ill he worketh still ; Himself, his servants, daily lie and lurk, Man's care on earth, or pains in hell to work. See how the case then with my debtors stands : They take the devil's office out of his hands; Tormenting me on earth, for passed evils, And for the devil, doth vex me worse than devils. In troth 'tis pity, proper men they seem, And those that know them not, would never deem That one of them would basely seem to meddle, 'To be the devil's hangman, or his beadle. For shame, for honesty, for both, for either, For my deserts desertless, or for neither Discharge yourselves from me, you know wherefore, And never serve or help the devil more. I have heard some that lawyers do condemn, But I still must, and will speak well of them; Though never in my life they had of me Clerk's, counsellor's, or yet attorney's fee, Yet at my back return, they all concurred, And paid me what was due, and ne'er demurred. Some counter serjeants, when I came again, Against their natures, dealt like honest men. By wondrous accident perchance one may Grope out a needle in a load of hay: And though a white crow be exceeding rare, A blind man may, by fortune, catch a hare, So may a serjeant have some honest tricks, If too much knavery doth not overmix. Newgate, the university of stealing, Did deal with me with upright honest dealing; My debtors all, for ought that I can see, Will still remain true debtors unto me; For if to paying once they should incline, They would not then be debtors long of mine. But this report I fear, they still will have, To be true debtors even to their grave. I know there's many worthy projects done, ' The which more credit, and more coin have won, And 'tis a slame for those, I dare maintain, 
That break their words, and not requite their pain :

I speak to such, if any such there be,

If there be none, would there were none for me.

Thus all my debtors have increased my talent,

Except the poor, the proud, the base, the gallant.

Those that are dead, or fled, or out of town :

Such as I know not, nor to them am known,

Those that will pay, of which there's some small number,

And those that smile to put me to this cumber,

In all they are eight hundred and some odds,

But when they'll pay me's only known to God.

Some crowns, some pounds, some nobles, some a royal,

Some good, some naught, some worse, most bad in trial.

I, like a boy that shooting with a bow

Hath lost his shaft where weeds and bushes grow,

Who having searched, and raked, and scraped, and tost

To find his arrow that he late hath lost:

At last a crotchet comes into his brain,

To stand at his first shooting place again :

Then shoots, and lets another arrow fly,

Near as he thinks his other shaft may lie:

Thus vent'ring, he perhaps finds both or one,

The worst is, if he lose both, he finds none.

So I that have of books so many given,

To this compared exigent am driven:

To shoot this pamphlet, and to ease my mind,

To lose more yet, or something lost to find.

As many brooks, fords, showers of rain and springs,

Unto the Thames their often tribute brings,

These subjects paying, not their stocks decrease,

Yet by those payments, Thames doth still increase:

So I that have of debtors such a swarm,

Good they might do me, and themselves no harm,

Invective lines, or words, I write nor say

To none but those that can, and will not pay:

And whoso pays with good, or with ill will,

Is freed from out the compass of my quill.

They must not take me for a stupid ass,

That I, unfeeling, will let these things pass.

If they bear minds to wrong me, let them know, 


\section{A KICKSEY WINSEY.}

I have a tongue and pen, my wrongs to show;

And be he ne'er so brisk, or neat, or trim,

That bids a pish for me, a tush for him;

To me they're rotten trees, with beauteous rinds,

Fair formed caskets of deformed minds.

Or like dispersed flocks of scattered sheep,

That will no pasture, or decorum keep :

Some wildly skipping into unknown grounds,

Stray into foreign and forbidden bounds ;

Where some through want, some through excess have got

The scab, the worm, the murrain, or the rot.

But whilst they wander guideless, uncontrolled,

I'll do my best to bring them to my fold;

And seeing sheepfold hurdles here are scant,

I am enforced to supply that want

With railing: and therefore mine own to win,

Like rotten forlorn sheep, I'll rail them in.

\section{IN DEFENCE OF ADVENTURES UPON RETURNS.}

Forasiruch as there are many, who either out of pride, malice, or ignorance, do speak harshly, and hardly of me and of divers others, who have attempted and gone dangerous royages by sea with small wherries or boats, or any other adventure upon any voyage by land, either riding, going, or running, alleging that we do tempt God by such perilous courses, which indeed I cannot deny to be true; yet not to extenuate or make any faults less than they are, I will here approve that all men in the world are adventurers upon return, and that we do all generally tempt the patience and long suffering of God, as I will make it appear as followeth.

Whosoever is an idolator, a superstitious heretic, an odious and frequent swearer, or liar, a griping usurer, or uncharitable extortioner, doth tempt God, adventure their souls, and upon return, lose heaven.

Whosoever is a whore-master, doth adventure his health, and wealth, and his returns are endless misery, beggary, and the pox: 
Whosoever doth contrive, plot, or commit treason, doth adventure his soul to the devil and his body to the hangman.

Whosoever doth marry a young and beautiful maid, doth adventure a great hazard for a blessing or a curse.

Whosoever goes a long journey, and leaves his fair wife at home, doth most dangerously adventure for horns, if she be not the honester.

He that sets his hand to a bond, or passes his word for another's man's debt, doth adventure a great hazard to pay both principle and interest. Probatum est.

That pastor who is either negligent or uncharitable in his function, doth adventure more than he will ever recover.

A merchant doth adventure ship, and goods, amongst flats, shoals, deeps, pirates, shelves, rocks, gusts, storms, flaws, tempests, mists, fogs, winds, seas, heats, colds, and calms, and all for hope of profit, which often fails.

That tradesman that daily trusts more ware than he receives money for, doth adventure for Ludgate, a breaking, or a cracking of his credit.

$\mathrm{He}$ or she who are proud either of beanty, riches, wit, learning, strength, or any thing which is transitory, and may be lost, either by fire, water, sickness, death, or any other casualty, do adventure to be accounted vainglorious, and ridiculous coxcombs.

He that puts confidence in drabs, dice, cards, balls, bowls, or any game lawful or unlawful, doth adventure to be laughed at for a fool, or die a beggar unpitied.

He that eats and drinks till midnight, and fights and brawls till day-light, doth adventure for little rest that night.

To conclude, I could name and produce abundance more of adventurers; but as concerning adventuring any more dangerous voyages to sea, with wherries, or any extraordinary means, I have done my last, only my frailty will now and then provoke me to adventure upon some of those infirmities or vices, which attend on our mortalities, which I think I shall be free from committing before my debtors have paid me all my money. 


\section{$A \mathrm{~N}$ ARMADA}

or

\section{NAVY OF 103 SHIPS AND OTHER VESSELS}

WHICH

Have the art to sail by Land as well as by Sea.

Morally rigged, manned, munitioned, appointed, Set forth, and victualled

With 32 sorts of ling, and with other

Provisions of fish and flesh.

The names of the ships are on the next page. 


\section{THE NAMES OF THE SHIPS, WITH THE NUMBERS OF THE SQUADRONS.}

1.-The Lord-Ship, whose squadron was of ships and other vessels, twelve in all.

2.-The Scholar-Ship, with ten others in all.

3.-The Lady-Ship, with twelve others.

4.-The Goodfellow-Ship, with twelve others.

5.-The Apprentice-Ship, with four others.

6.-The Court-Ship, with eleven others.

7.- The Friend-Ship, with four others.

8.-The F'ellow-Ship, with five others.

9.-The Footman-Ship, with five others.

10. -The Horseman-Ship, with four others.

11.-The Surety-Ship, with seven others.

12.-The Wor-Ship, with three others.

13.-The Woodman-Ship, with seven others.

Besides, there were seven other needless ships, which were in the nature of voluntaries, or hangers-on upon the navy, as, namely, the Merry Carry-on, the Knave's-Increase, the Superfluous, the Careless, the Idle, the Coxcomb, the Braggart. And whatsoever he be, that hath, or doth not sail in some one ship of this my fleet, let him come to me, and I will ship him and give him double wages. 


\section{TO THE RIGHT WORSHIPFUL AND TRULT GENEROCS SIR JUHN FEARNE, hoight.}

\section{Noble Sir.}

THE world sufficiently knows that rou know what Ships and shipping are, that rou hare ploughed the dangerous ocean, and furrowed orer the ragrod bosorn of Neptuse: ret nerertielese I know that rou hare touk notice of m? old and weatber-beaten Lard-Nart being built withud: either timber or irup, rigged without ropes or euniage, whose ordanove are diacharged without natch or powder, whase rictuals are neither bread, ding fis. Atesh, or good red-berriog, whose ropages are not perfurned with wind and water, ret erer in action lite a perpetual motion; but whei rou shall please to farour me so moch as to percse aud surrey zor etrange Fleet or Armada, rou will the perceire that jourself bath saled no, or at the least boarded rave of nir ships of note: fur rou are well arquainted with the Lordsbip, rou are a friend to the Scinularship, ret hare laid the Ladrebip abrand, rou hare eatered the Apprenticeship. rou are well-kown in the Cuurtship, rou hare sailed in the Gord Fellomsbip, rou lore the Frieudship, rou affect the Fellowship. Tou know the Footmanship. rou are skilled in the Hureevanohip. Tou hare surprised aud taken the Wurkbip. and rou koow what belougs to the Woulenarship. the Wardsip, and Stewardship; I do fur some reasuns nut medile with all, and I think rou hare seldum or nerer had aus dealings with them: the sum of all is I most humbly desire Your workhip's pardup, for wr abrupt dedicatios, assuriug rou that it was only me lore aud dut that put me on, without ant expectance of patronage, protectivn, or reward: and with int best wiskes for the perpetuity of Jour present and ETer future felicitr,

$$
\text { I rest. }
$$

Tour Worsbip: to command

whilst I hare being, JO. TAILOR. 


\section{John Smith of his friend Master John Taylor and his Armada.}

Arm, arm, arm, arm, great Neptune rouse, awake And muster up thy monsters speedily :

Boreas unto thy blustering blasts betake, Guard, guard yourselves, from Taylor's policy; Rocks, shoals, lee-shores, oh help them Goodwin sands For this new fleet runs over seas and lands, And's now so victu'led, rigged and yarely plies It threatens all the waters, air, and skies, Truth in his navy such a power doth lead The Devil, Hell, vice, and all, the fleet may dread, And well it may, if well you understand, So rare a fleet, was never made nor man'd.

\section{THE DESCRIPTION, HOW THE WHOLE NAVY IS} VICTUALLED WITH THIRTY-TWD SORTS OF LING, BESIDES OTHER NECESSARIES.

First, thirty thousand couple of Change-Ling, appointed only for the diet of such fellows who had honest parents, and are themselves changed into very rascals.

Secondly, Dar-Ling, this fish was dearer than fresh Salmon, for it was consecrated to the goddess Venus, it was of that high price that some men have consumed their whole lordships, manors, and credit, in two or three years only in this kind of diet, therefore, it is not a dish for every man's tooth: for none but brave sparks, rich heirs, Clarissimues and Magnificoes, would go to the cost of it.

Thirdly, Shave-Ling, which was only for the diet of Pricsts, Monks, and Friars.

Fourthly, Fond-Livg, this fish was Cockney's and other pretty youths, over whom their parents were so tender, that a man might perceive by their manners, they had been better fed than taught.

Fifthly, Tip-Ling, a dish for all men.

Sixthly, Under-LING, this fish was shipped for witty 
younger brothers, poor scholars that have neither friends nor money.

Seventhly, Starve-Lrng, this ling was only for the bark beggarly, which was manned with old discharged servingmen, and maimed cashiered soldiers and mariners.

Eighthly, Strip-Liva, provided for pages, lackeys, and foot-boys.

Ninthly, Foo-Ling, a dish for every man's diet.

Tenthly, Swad-Ling, against stomach, but yet a dish of good use.

Eleventh, Grumb-LING, a discontented kind of fish for the poorer sort of people to chaw upon; for when they do think themselves wronged by their superiors, and dare not utter their minds openly, then they feed upon GrumbLING.

Twelfth, Wrang-Ling, this ling was salted by sixteen pettifoggers, in a long troublesome term; it is held to be a lasting dish, and will serve the whole fleet with their posterities, to the second and third generation.

Thirteenth, Troub-LiNG, was provided by certain double diligent constables, to the molestation of their sleepy watch, and the charge of many a man that would quietly have gone to their lodging.

Fourteenth, Prow-Livg, is a plentiful fish, upon which many thousands do live, but by using it too much, it chokes a great number; and as fishermen do bait their hooks with one fish to catch other, so is this ling, for the most part, taken with three other sorts of ling, as with Jug-Ling, Brab-Lisg, until by hook or by crook it is taken with Ang-Ling, I have seen many of these ProwLING fishermen end their lives like swans, in a manner singing, and sometimes making their wills at Wapping, or looking through a hempen window at St. Thomas Waterings, or the three legged instrument near Paddington. There were many other sorts of ling sent to the Navy, which, to avoid prolixity, I will but name, as Quarrel-Ling, was for the diet of some of the noble science, some for roaring boys, and rough-hewd tittery tues.

The nineteenth sort of Ling was Fumb-Ling, which is 


\section{EARLY PROSE AND POETICAL WORKS.}

for their diets who have been long married and can get no children.

The twentieth, was Ming-LiNG, which was for wine merchants, vintners, brewers, and apothecaries. JumbLING, and Tumb-LiNG, for the keepers and Cupidian haunters of vaulting houses. Fid-Ling, Fud-Ling, and Stump-LiNG, from the schools of dancing and drinking.

The twenty-sixth sort of Ling was Bung-Ling, which was the fare of quack salvers, mountebanks, ratcatching: watercasters, and also for all botching artificers and cobbling tradesmen. Mumb-LiNG was for those that had no need of the tooth-drawer. Ster-LiNG money was at such a Scant-Livg, that scarcely it was for any honest man's Hand-LiNG.

The thirty-one sort of ling was Pole-Ling, I do not mean a Pole of Ling, nor Barber's Pole-LiNG, which is an universal dish, it needs no mustard, for many a commonwealth finds it tart enough without sauce, yet many men have run in and out of great estates by this only fish : it serves for the diet of project-mongers, monopolitanians and diligent suit-joggers.

The last Ling was Pill-Ling, which is much of the nature of Pole-Ling, and so with Pole-LiNG and Pill-Ling, I conclude my thirty-two sorts of Ling.

For other sorts of fish they had Carp enough for a word speaking, great store of Cods-heads, Sharks more than a good many; plenty of Dog-fish, and Poor-Johns in great abundance.

For flesh it was so plentiful, that he that loved beef might have every day a stone if he had a stomach to eat it: their mutton was neither ewe nor lamb, but to my knowledge they wanted no weather; they had also good sort of venison, but it was rascal dear, or deer-rascals with some fawns; they had likewise store of fowl, as gull, goose, widgeon, woodcock, buzzard, owls, cormorants, quails, rails, cuckoos, wag-tails, ring-tails, and bittoures. Their fruit was medlers and wildings, and instead of a flawn or a custard, they were glad sometimes to dine and to sup with fool!

For preservation of their healths, they had neither 
Mithridate, or any other drug. For one Doctor Scourgut, who married with Florence, the only daughter to Sir Reverence Stirstink, of Holehaven in the county of Ruffmillion glisterpipe-maker, was the physician to the whole navy, who did compound a preservative of powdered coxcombs with ass's milk, which did very well agree with their natures.

Their bread and drink I had almost forgotten; indeed it was not rusk as the Spaniards use, or oaten-cakes, or bannocks, as in North Britain, nor biscuit as Englishmen eat; but it was a bread which they called Cheat-Bread, and a mad fellow told me, it was so called, because the baker was never like to be paid for it. Their drink was brewed with a malt, made only with wild-oats, but instead of hops, there was store of rue, with a little heartsease. And thus were they victualled. Now I proceed to the description of the Navy.

\section{WHY THESE SHIPS ARE CALLED SHIPS.}

I HAVE little to say to the reader, because I neither know him nor his conditions, therefore to avoid lying and flattery, in putting the styles of christian, gentle, courteous, friendly, learned or honest, upon the atheist, barbarous, hateful, ignorant, or dishonest; the reader gets no epistle at all of me: if he be good and well inclined, it is the better for himself; and if otherwise, it shall not be much the worse for me, there's the point. Now the reasons why all these words, or names of my moral navy are called ships, or do end with the word or syllable ship, as Lord-SHIP, Lady-SHIP, Friend-SHIP, and the like, etc. The reasons I take to be these which followeth, and as I imagine most significate; first the whole life of man is a ship under sail; for be it either day or night, storm or calm, light or dark, hot or cold, winter or summer, yet the ship is in her course, ever going in her voyage; so likewise man, let him go, sit, stand, ride, run, work, play, sleep or wake, yet he is still going onward in his mortal passage. A ship is ever in need of repairing, so is a man either in body, mind or 
goods. A ship is ever unsteady; a man is always mutable; some ships are hard to be steered; some men are harder to be guided. Some ships bear so great a sail that they bear their masts by the board and make all split again: some men do spread such a clew in a calm, that a sudden storm half sinks them and tears all. Some ships are so favoured by the wind, that they make rich voyages and quick returns; some men are so fortunate, that wealth and promotions do fall in their mouths. Some ships run through many a storm with much danger, and yet are so unlucky, that they never make a good voyage; some men being born under a three-penny planet can neither by pains, watching, labour or any industry be worth a groat. Some ships by being overladen have been cast away; some men by taking in too much have been forced to cast all away. Ships do wallow and heave, and sit upon the sea; men do stumble, reel and stagger on the land. Some ships have their cracks and imperfections gaily hid with painting; some men have their bad intents covered over with hypocrisy, and their diseased carcases covered with good clothes. Some ships do bring profitable commodities, and some bring baubles, toys and trifles; some men do enrich a kingdom with their wisdom, authority, and practice in virtue: and some men do disgrace and impovish a monarchy by folly, ill employed power, and sottishness in vanity. Some SHIPS will run to leeward extremely if the wind be scant, some again will bravely beat it out to windward and weather it; so some men will shrink from their friends or from themselves in a storm, or trouble, or poverty; and some few again will bear up stiff, constantly, contemning and opposing the brunts of Fortune. Some SHIPs are taken by others and made prizes; some men are captived by others and made slaves. Some SHIPs are commended more for their bulk and beauty, than for any good service; and some men are more applauded for their fortunes, than for any good conditions. If I would insist longer on these comparisons, I could enlarge my induction to the bounds of a pamphlet; therefors I will conclude it with King Solomon's simili- 
tude, Wisdom 5. cap. 10. That man's life passeth as a SHIP that passeth over the waves of the waters. Therefore I wish all men to be provided as good ships should be, let HOPE be their cable, let charity and love guard and compass, till they come happily to the haven of GRAVESEND, and from thence to that blessed Harbour which hath no END.

\section{THE LORD-SHIP IVITH HER REGIMENT.}

THE LORD-SHIP, a very ancient and honourable vessel of mighty bulk and burthen, being sufficiently furnished with victuals, munition, tackling and men, was under the command of the noble Don Diego de fifly Cankoemuskcod, who was Admiral or high Adellantado of the whole fleet. The captain of her was Signor Caco Fogo, a Neapolitan of Civita Vecchia, a sweet affable gentleman, yet of so dainty a disposition, and so experienced in navigation, that he could not endure the scent of the pump, and for the more sweet keeping of the ship, he protested that he would have no more of those stinking pumps to sea with him. He came very honestly by his place, for he bought it with his money, besides the help of a lady's letter; and to give him his due, he was well skilled in the Ass-trolabe, and could take the elevation of the pole, as well with a batoon or a broom-staff, as with any Jacob's staff in Africa. In foul weather he most constantly kept his cabin, giving himself wholly to fasting and meditation, often casting up his accounts as near as he could, bearing himself so equally betwixt welldoing and ill-taking, that in all the whole voyage no man could tax him for taking any harm, or doing any good.

The Master's name was Petrus Vainglorious, his Mate, Hugo Hypocrisy, men that have steered the course in the Lord-SHIP many hundred years : the boatswain and his mate were Scoff and Derision, with Gripe the Steward, Avarice the Purser, and Lawrence Delay the Paymaster; kinsman to Tom Long the Carrier. Which three last are 
thought to be very arrant knaves, who have spoiled the government of the whole ship. In brief, the Gunner, Coxswain, Swabber, and Ship-boys were plentifully stored with pride, flattery, and other the like gentlemanlike virtues.

The ships that went in the same regiment or squadron, with the Lord-SHIP, were these that follow, namely,

1 The Ambition; 2 The Presumption, two stout ships of very lofty sail and great burthen.

3 The Oppression, a ship of account and estimation.

4 The Costly, a ship of great charge.

5 The Mutable, a brave ship, but in no course steady.

6 The Self-love a great ship, but of small service.

7 The Delight, a fair ship to the eye.

8 The Hopevell, a ship of great expectation.

9 The Debt, a ship of great burthen and much receipt.

10 'The Satisfaction, a large long ship, a very cart, a slug and slow of sail.

11 The Promise, a ship very unsteady, yet her sails ever full.

\section{THE SCHOLAR-SHIP WITH HER REGIMENT.}

THIS Ship is a very ancient ship, and was built at the first, and hath been ever since repaired with infinite cost, pains, and study. She hath been of that worthy estimation, that the monarchs, kings, princes, and estates of the world, have made it their chiefest felicity to sail in her: all famous divines and philosophers have steered her and been steered by her. Some of our greatest mariners have ben much troubled with plurisies, pluralities I would say, and some have been great merchants at steeple fair, but it was in the old time, Si-Money, was as good as ready Money. The arts mathematical and metaphysical have been the rich prizes and purchases of her painful voyages: and now at this present, though the world be much altered with her, she tries her fortunes in this adventurous navy. The captain's name was Sapience, the master Experience, his mate Knowledge, and every other officer correspondent, being munitioned and victualled 
for the enterprise, she set sail, with her squadron or regiment of ships hereunder named.

1 The Serious, a ship laden with gravity.

2 The Foresight, a ship worthy of much regard.

3 The Desert, a ship of great service and small payment.

4 The Industrious, a good profitable ship.

Then there attend her five small pinnaces and frigates, namely, the Dogmatist, the Captious, the Prejudicate, the Carper, and the Critic. These five were manned with young bachelors of art, puny inns of courtmen, and humorous Poets, who with their continual cudgeling one another with broken verses had almost beaten Priscianus' brains out.

\section{THE LADY-SHIP WITH HER REGIMENT.}

This Lady-ShIP was a very comely ship to the eye, set out with most excessive and superfluous cost, she was most richly adorned and beautified with flags, streamers, pennons, and waistcloths. There was more time spent in rigging of her, than in all the rest of the fleet one after another. Her cordage and tackling was of fine silver twist, only her ent'ring rope was pure gold; her sails were silk, of all the colours in the rainbow; her masts and yards were strong and serviceable; her guys, bowlines, sheets, tacks, braces, ties, and lifts were all very costly; her gaskets, marlines, cables, hawsers, fish, and cat rope, buoy rope, and boat rope, bolt rope and top rope, the guest rope, bucket rope, and fort rope, shrouds, lanyards, ratlings, halliards, ropeyarns, sounding lines, were all of rare stuffs of great price and small profit. And contrary to any other ship, she had neither forestay or backstay, for the wind lay in her will, and if she please to sail any whither, there was no command had power to stop her, or cable and anchors strength to hold her. In a word, she was a fine timbered vessel, and had the virtue to sail without any compass, and indeed she was altogether for fair weather, for if it stormed, rained, or blew, or sun shined 


\section{EARLY PROSE AND POETICAL WORKS.}

too hot, she would lie at anchor, and keep her harbour a month together, so that neither force or fair means" could ever unmove her.

Her ordnance or artillery were in her chase or head, and her powder or munition were in her stern or poop, she is somewhat tickle in steerage, but in sight she is sufficient to sink or blow up, as many as dare board or grapple with her. She was laden out with poor beggarly commodities, as lead, tin, leather, tallow, corn, and broadcloth, but she came richly fraughted home with apes, monkeys, merkins, marmosets, Spanish potatoes, ostrich's feathers, island dogs, St. Martin's beads and bracelets, cobweb-lawn, tiffanies, dainty dun Popinjay green parrots, and paroquets. The master's name was Vanity, who had the chief command and guide of the ship and regiment, who in steering of his course, was neither miserable or liberal, but altogether a most worthy, worthless, careful, negligent, prodigal.

The other ships and vessels that were in her regiment under her command, were named as followeth.

1 The Dainty, a ship purposely built for the carriage of such things as were far fetched and dear bought, and by consequence proverbially good for ladies.

2 The Pride, an intolerable gaudy vessel, of an exceeding lofty sale, with top and top gallant.

3 The Coy, a little frigate, of small service.

4 'The Disdain, a great ship of much use, but of very strange course or steerage.

5 The Nice, a frigate that carried the sweet-meats or confectionery.

6 The Fashion, a galleyfoist, only for the service of the wardrobe.

7 The Bauble, a small frigate only for pleasure.

8 The Toy, a pinnace, that was appointed to attend and follow the Fashion.

9 The Wanton, a catch.

10 The Gewgaw, a hoy.

11 The Whimwham, a drumler.

All these three were of most special use and service for the Lady-SHIP, whose chief charge and employment 
was to wear, eat, and drink the best, 'and withal not to pester, wrong or oppress the fleet, with good examples or directions.

\section{THE GOOD-FELLOW-SHIP WITH HER REGIMENT.}

This Ship is very old, and much out of reparations. She hath been of such use and employment, that she hath sailed into all countries of the inhabitable world; she only is the greatest traveller, for there is not a haven or harbour under the sun, but she hath cast anchor in it. Wine merchants, vintners, brewers, and victuallers, have thrust themselves into the whole Lordships, by the often returns, lading and unlading of this ship, yet now she is so weather-beaten, with the storms of time, and so windshaken with too much use, that through want she is not able to bear half the sail which she formerly hath done.

In the golden age, when Saturn reigned, long before the two wrangling words Thine and Mline had set the world together by the ears, then was the Good-fellowship in such request, that all estates and conditions sailed in her, then her voyages and quick returns, her lading being for the most part hearty love and true affection, did maintain and keep such unity, that whosoever was not a mariner or sailor in her, was esteemed as a branded, stigmatized, infamous person.

But at last her navigators began to steer another course, for some of them had learned the art of covetousness, and with a devilish kind of bawdry, called usury and extortion, made gold and silver engender and beget yearly so much, and so much the hundred, when tailors, like so many wicked spirits, flew from one country to another, bringing home more fashions than would kill a hundred thousand horses. When for the maintenance of those fashions, the earth was equally shared and divided amongst the people, some all, and some not a foot, with hedges, ditches, bounds, mounds, walls, and marks, when my Lady Rusty began to take such'a thrifty order, that 
all the meat in the kitchen should be cheaper than the washing and painting of her visage, if you allow the powdering of her bought or borrowed perriwig into the bargain, when the world came to this pass, then this good ship, this Good-fellowship being forsaken of her pilots, masters, and mariners, all her sailors in little time declined to be no better than swabbers, so that through want of skilful managing and reparation, and with extreme age, she is nothing so serviceable as she hath been, yet as she is, she sets forward with her best ability in this voyage. The captain's name was Hercules Dumplin, a Norfolk gentleman, the Master, Giles Gammon, he was born at Romford, the rest of the mariners it were needless to name them.

The other ships and vessels that were in the same regiment with the Good-fellowship, were these.

1 The Drunken Siss, a great ship, it is thought she was built at Middleborough; but howsoever, she hath made many voyages into England: she is so beloved, that she needs not press any man to serve in her, for all sorts of people do daily come aboard of her, and freely and voluntarily offer her their best service, so that it is a wonder to see how bravely she is manned: and many times women do take their turns at helm, and steer their courses as well as men. She is a ship contrary to all other ships, for she rolls, reels, and tumbles most of all when she is in a calm harbour, and the more lading she takes in, the more unsteady she is; for if the sea be as calm as a milk-pan, yet is she ever tossing, which makes her mariners sea sick and subject to much casting. Her ordnance are gallons, pottles, quarts, pints, and the miser's gallon; with three hooped pots, cans, godards; in the which artillery almost every one hath the skill to charge and discharge, maintaining the fight as long as they can either stand or understand. The master of her is an Amsterdamn'd man, his name is Cornelius von Broken-gulch; the master gunner was one Denis Whirlpool, a man of Dieppe, with Gulph the purser, Swallow the boatswain, and Swill the steward.

2 The second ship in the regiment with the Good- 
fellow-ship was the Sow of Flushing, she was a vessel unseemly to the eye, but yet serviceable.

3 The Carouse, a ship of hot service, and as the spider sucks the sweetness of the fairest flowers, converting their juice into poison, so the sailors in this ship have taken a use to drink other men's healths, to the amplifying of their own diseases.

4 The Quaff, a quick smart ship much of the bulk and carriage of the Carouse.

5 The Bissle of Breda, a small ship, yet in continual service, her worst fault is, she is so low built, that her mariners can hardly keep themselves dry.

The Sleeper of Rotterdam, a great ship, of exceeding necessary use, and much employment, she is to the whole regiment, in nature of an hospital or spital, for when any of them are wounded, pot-shot, jug-bitten, or cup-shaken, so that they have lost all reasonable faculties of the mind, and in a manner are so mad, that they dare speak felony, whistle treason, and call any magnifico a mongrel; in such desperate cases as this, the distracted parties are brought aboard the Sleeper, where Time like a good cloth worker, with setting a good nap upon their threadbare eyes, their wits that were spent, and like northern cloth shrunk in the wetting, are speedily recovered.

So likewise for the limbs and members of the body, she is the only Asculapian Tabernacle; and to speak the truth, St. Winifred's Well; the Bath, or the Spa, are not compared to this ship, for speedy ease and cure; for I have seen many that were, so dim-sighted, that they could not see their way at noon-day, and others have been so defective in their speech, that they could not speak one wise word; others so lame of their legs, that they could neither go or stand, and with a few hours lying aboard of this easy ship, their sights, speech, and legs, have been all recovered.

7 The Whiff, a small pinnace of Varna.

8 The Puff, a bark of Virginia.

9 The Vapour, a frigate of Trinidado.

10 The Snuff, a carvel of Burmudas.

11 The Bark-beggarly, before mentioned, manned with 


\section{EARLY PROSE AND POETICAL WORKS.}

old cashiered soldiers, mariners, and servingmen, negligent tradesmen, with some few courtiers, whose diet is only Starve-Ling.

\section{THE APPRENTICE-SHIP.}

THIS ship is very slow of sail, so that a man may make two East India voyages, or girdle the terrestrial globe twice about, as Sir Francis Drake did once, before she can make a return; the compass whereby she shows her course is for the most part in our Troynovantine ocean, within the sound of Bowbell. Instead of a map or chart, she is directed by an indenture, whereby she hath more knowledge in the time to come, than any witch or conjurer; for by only looking on it, the least ship-boy that's in her, can tell when her voyage will be done. She is a vessel that is both singular and single, for none but single persons must board her; and to avoid double dealings she hath banished matrimony out of her quarters, for seven years or more; her mariners do, against their wills, endure much hardness, as hunger, thirst, heat, cold, watching, toil, and travail; yet many times they are allowed more lamb and ribroast than they would have; yet by patience and long-suffering, many of them do change to be preferred. In time, they sail in the LordSHIP, Court-SHIP, Surety-SHIP, or some other bottom of honour or eminency; for they claim a freedom of all trades whatsoever, and are so mystical in their diversities of mysteries, that not one man living can describe them. Yet for the most part weight and measure are their guide, by weight from the scruple to the dram, to the tun, to the three tuns, and to the three hundred thousand millions; and by measure from the half-quarter pint to the whole quarter sack; from less than the inch to the ell, to the furlong, to the firmanent, and down to the bottom of the cellar, to the ocean and the tailor's bell, who indeed are accounted the best bread men in the ship, and such as go through stitch with what they take in hand. There are divers functions which never do come aboard of this ship, as cuckolds, wittols, and others which I could name; but 
to supply these wants, she is seldom unfurnished of young lying knaves, whores, and thieves, who, as the cockle grows among the wheat, do sail in the Apprentice-SHIP, and share as much benefit as most of her labouring mariners. She hath small attendance, for indeed she is the ouly bounden servant in the navy, only there is a sluggish vessel called the Tedious, that sails with her, with four small pinnaces, as-

1 The Lodge.

2 The Diet.

3 The Wash.

4 The Wring.

And sometimes double, single, or no apparel is allowed to the sailors when the voyage is ended.

\section{THE COUR'T-SHIP, WITH HER REGLMENT.}

CourT-SHIP, is a vessel of royal and magnificent burthen, of eminent command, and invincible force, if she be well manned, carefully rigged, discreetly ballasted and wisely steered; she is of that impregnable strength, that neither the storms of sancy censure, the gusts of malapert babbling, the flaws of envy, the tempests of temporizing talebearers, or the smooth calms of flattery, can make her sail to any other harbour than the famous ports and havens of virtue, honour, and perpetual happiness.

But, to use sea terms and phrases, there are a crew of unprofitable steal-shares, peremptory hot-shots, idle flatsheets, and unserviceable vessel's loose-guise, that do attempt to board this admired ship, and so having boarded her, like drones, they eat and live upon the labours and deserts of the painful, industrious mariners. These are the youths that after they have foisted themselves into some mean place of office, though it be but a swabber, liar, or liar's mate, always provided, that they have sworn themselves into good clothes, then let all their acquaintance and friends stand further off, for they esteem themselves to be no more mortal, so that a man had far better speak to the master and owner of the ship himself, than to any of these puck-foists. Yet there is 
great show of zeal in their salutation to any one they meet, for the word God save ye, it is as common as the air with them, but in effect they neither mind God, nor the party they speak to, and, like an ape for an apple, they can kiss their paw, inviting a man to their cabin; but whosoever takes them at their word, they hold him to want manners, and to be a fellow of no breeding. The ignorant ass that carried the Egyptian goddess Isis in procession, when the more ignorant people kneeled down to adore the goddess, the witless ass thought it had been in reverence to him: so in like manner these upstart ship-boys, having once crept into an inferior office in the ship, and withal being covered with silk, and good borrowed beaten satin, lined and buttered through with plush or velvet, they arrogantly imagine, that all the reverence or respect that men do, either for their undeserved place, or gaudy outside, is done to their persons. But I would have them understand, that they are honoured and worshipped, with the same devotion as the barbarous Brazilians, Americans, and Virginians do adore the devil withal, which is not for the hope of any good which they expect, but for fear of the hurt which they suppose the devil can do them. The conclusion is, that when a storm or tempest comes, the noble, stout, skilful navigator stands to his tackling, and courageously applies himself either to top and yard, helm and lead, from post to stem, and from prow to quarter, when all the service Monsieur Mushroom and his mate can do, is either to eat, sleep, spew, and stink, and at last for some notorious or meritorious work, they are ducked from the yard arm of State into the deep sea of disgrace, and turned ashore like Cain's imps, preferred to their due estates of runagates and vagabonds.

The squadron of ships that went under the command of the Court-ship.

1 The Renown, a ship of worthy port, strength, and burthen, manned with approved and experienced soldiers and sailors.

2 The Courage.

3 The Resolution. 


\section{The Foresight.}

5 The Expedition.

6 The Loyalty.

The Perseverance, six tall ships of most excellent service and performance.

7 'The Compliment.

8 The Brisk.

9 The Strange, three gallant pinnaces, but of very small use, profit, or service.

10 The Oblivious, a ship of great burthen and most plentifully manned with those that had forgotten their parents, kindred, friends, birth, estate, breeding, and indeed, such as were so far out of knowledge to know any man, that they had no acquaintance of themselves, and being mere strangers to their own qualities and conditions; and thus was the Court-ship appointed and attended. Much of the great ordnance, were promises, the powder breath, and airy performance were the shot, which by reason of the tossing of the billow, and unquiet surges of the sea, did often miss the mark.

\section{THE FRIEND-SHIP.}

WAS a vessel of great account and estimation, David and Jonathan, Damon and Pythias, Pleiades and Orestes, Alexander and Lodowick, Scipio and Laelius, did lovingly and unfeignedly sail in her: indeed she was ever free for all comers of what country, sex, age, or state soever, for the word friend imports free end, which is as much as the end and intention of Friend-ship is firee. In these latter times, she would have gone to sea, but there were not men to be gotten to man her, so for a shift they were feign to furnish her with kindred, uncles, and cousins, with here and there a false brother. Herod and Pilate went aboard this ship, with a shameful deal of love from the teeth outward, but their purpose was to destroy innocent blood. It was a merry world when Fidelity was master of this ship, Constancy his mate, and Plain-dealing the boatswain, but those worthy mariners are dead, and an old proverb, as sure as check with 
them; in a word, the old ship is decayed and rotten, having only the bare name left, for she is so much past service, that she can hardly steer or bear sail, with an adverse contrary gale, she will fall to leeward much abominably, yet with a prosperous and fortunate wind, she will spread all her canvass exceeding fare and hypocritical, and so to I will describe no further, because she is grown to that cheap rate, that a man may have her at Billingsgate for a box of the ear.

'The Friend-SHIP had two very small pinnaces in her squadron, named,

1 'The $\operatorname{Cog}$.

2 The Foist, other attendants she had few or none, for indeed none but these two and one great ship called the Fraud, were in request.

\section{THE FELLOW-SHIP WITH HER REGIMENT.}

THis ship was in old time a ship of unity and equality, when every man thought better of his neighbour than of himself, then the master and his mate, in loving sympathy, had inward fellow feeling of the griefs, pains, toils, labours, infirmities, and wants of the meanest sailor or ship-boy; but now the case is so altered, that though we be all of one house, yet not all fellows; and though all in one livery, yet, by your leave, no Fellow-SHIP, tor by that consequence, many times the page, the footman, the coachman and his horses might challenge Fellow-SHIP, by their trapping and comparable caparisons; indeed, self-love have bred such a disunion and disconsonance amongst men, that one thief doth disdain fellowship with another. So that this ship, to patch up her reputation in some poor fashion, because she will be manned and laden with none but with fellows, she carries none but foot-ball players and watermen. Her lading being ploughing-oxen, coach-horses, boots, spurs, shoes, pantofles, slippers, galoshes, gamashes, socks, cuffs, gloves, gauntlets, case of rapiers, and such things as were by art or nature coupled and made fellows; this ship was once of that estimation, that Julius Cæsar would have been content to 
have sailed in her, but that the great Pompey scorned any equality, and would by no means board the FellowSHIP with any man. In brief she is a vessel of such duplicity, that a fellow with one eye, one ear, hand, stone, leg, or foot, must not enter her, nor any sculler, or single souled person come within shadow of the smoke's shaduw of her ordnance.

The ships that went in her regiment or squadron were these.

1 The Iistrust, a ship that sails always near the Fellow-SHIP.

2 'The Pickthank, a ship of great employment, that commonly sails out of sight or hearing, her lading being for the most part, private complaints, whispering intelligences, and secret informations.

3 The Braxl, a turbulent ship in continual action.

4 The Snarl, a small dogged pinnace, of more use than profit.

\section{THE FOOT-MAN-SHIP IVITH HER REGIMENT.}

THIs ship is of most ancient and greatest antiquity, for she was before any other ship was thought on, our old father Adam sailed in her, and was the first footman in the world. And Prince Absalom the son of David had no less than fifty of these terrestrial amblers to pass before him; how it came to be called a ship, I cannot relate, but by an anagrammatical or mystical conjecture, the only trade of a footman is rumning, and running a way, and quite contrary to valour or manlood, he is accounted the best man amongst them, that can run fastest, and he is called and esteemed a man of good Footman-SHIP; which word anagrammatized, is foe to Man-SHIP, importing, that running away is an enemy, or foe to manhood, valour and resolution, thus much by way of paradox.

Let the wind blow where it will, yet at all weathers this ship sails a trot, her light-footed, nimble-heeled mariners like so many dancers capering in the pomps and vanities of this sinful world, sometimes a morisico or trenchmore of forty miles long, to the tune of "Dusty my 


\section{EARLY PROSE AND POETICAL WORKS.}

dear," "Dirty come thou to me," "Done out of the mire," or "I wail in woe and plunge in pain," all these dancés have no other music, except now and then he chance to hear an oath or a curse or two from the coachman.

The sailors, the most part and best of them, are bred in a kingdom of much fertility and plenty, called Realdine, where, after they have all their youth been accustomed to wear brouges and trousers, their fare being many times shamrocks, oaten-bread, beans, and butter milk, armed upon stark naked, with a dart, or a skean, steeled. with the spirit of Usquebaugh, then they cross a ditch of eight hours sail, and land in the most flourishing kingdom of Triabnie, where by their good Footman-SHIP they are turned out of their old habits, into jackets of good preterpluperfect velvet, plated with silver, or Argentum vivum, for the quickness, and all to be embroidered back and side, with the best gold twist, and the best of the silkworm, sometimes with a court, a coat of guard I should say, or a coat of regard, being well guarded, unregarded, with such as deal of feather, ribbons and points, that he seems to be a running haberdasher's shop of small wares.

Yet are those men free from pride; for their greatest ambition is, not to ride, but to foot it, or else to sweep chimneys, or to turn costermongers. This is the altitude of their aim, and the profundity of their felicity, nevertheless they know themselves to be great men's trappings, courageous torch-bearers, illustrious fire-drakes, glorious and sumptuous turmoilers, they are far from the griping. sins of usury and extortion, and are such philosophical contemners of the world, that every day they tread it under their feet and trample on it; and they are such haters of wickedness, that they leave it in all places where they come. They are not covetous of other men's lands, for they make all the haste they can every day to leave it behind them; they are so much to be trusted, that their words are as good as their bonds, yet in this their humility they may compare with Emperors, for they are as brave as Nero, and can drink with Tiberius; to conclude, the Footman-SHIP is manned with well breathed mariners, who after all their long, painful, and faithful 
service, are shipped in the bark-Beggarly, and brought to an anchor in the haven of Cripplegate.

There were in the regiment with the Footman-SHIP four small pinnaces.

1 The Sweat, a vessel of warm employment or hot service.

2 The Moil, a frigate that will endure much foul weather.

3 The Toil, a bark for all weathers, winter or summer. 4 'The Cripple, an old drumler quite past service.

\section{THE HORSEMAN-SHIP WITH HER SQUADRON.}

HorSEMAN-SHIP had not so fair a beginning as FootmanSHIP, for Cain was the first vagabond and runnagate in the world, was also the first that backed and managed a horse, as Polydore Vergil saith, no doubt after he had murdered his brother, seeing he could not run from the horror of his conscience, he practised Horseman-SHIP, because perhaps he thought to ride from himself. This ship hath more paces than time hath; and the comparison may hold well, for in long vacations, quarter days, against payment of bonds, absence of true friends, or protracting of maids' marriages, after the banns have been asked, in these cases the lawyer, the landlord, the usurer, the friends, and the contracted couple, do think time to be foundered, and stark lame, or quite tired, and that his best pace is after fourteen miles in fifteen days; whilst many a poor client, an unprovided tenant, or unfurnished debtor, or a fellow going to be hanged, they think time is all upon the spur, and that he runs at full speed a wild gallop. And as a ship at sea sails sometimes by the wind, sometimes before the wind, sometimes with a quarter wind, sometimes with a flown sheet, and sometimes with tack hard aboard, and bowling stretched and sheet close after, by all which winds she sails several paces; so Horseman-SHIP hath the trot, the amble, the rack, the pace, the false and wild gallop, or the full speed, and as several vessels at sea do make a navy, as carracks, argosies, hulks, ships, barks, pinnaces, hoys, drumlers, 


\section{EARLY PROSE AND POETICAL WORKS.}

frigates, brigantines, carvels, catches, gallies, gallions so this Horseman-SHIP hath to attend her, her Spanish Jennet, her Barbury IIorse, her Naples Courser, her German Steed, her Flanders Mare, her Galloway Nag, her Irish hobby, her French Cheval, her Welsh Palfray, her English All, her Smithfield Jade, and her Bartholomew hobby horse; and contrary to all ships, which have their bridle, helm or rudder in their stern or tail, the Horseman-SHIP is altogether directed and steered by the head, whereby, for want of good managing, many. times the rider makes a head-long voyage, like a man of good forecast, over the horse's head. And as horsemen are none of the best mariners, so mariners are commonly the worst horsemen, as one of them being upon a tired hackney once, his companions prayed him to ride faster, he said he was becalmed.

Another mounted upon a foundered jade, that stumbled three or four times, headlong, the sailor imagined that his horse was too much laden ahead, or forward on, as the sea phrase is, and therefore to ballast him, that he might go or sail with an even keel, he alighted and filled his jerkin sleeves full of stones, and tied them fast to his horse crouper, supposing to make his stern as deep laden as his head, to avoid stumbling.

Indeed this Horseman-SHIP is never unfurnished of a jades trick, or two at a pinch or time of need, and contrary to any other ship, in the fairest weather it will heave, set, wince, kick, fling, and curvet, like a midsummer morris-dancer, or as if the devil were practising a French Lavolta or Corranto. But I cannot blame them to be lusty, for they are not put to such hard allowance as many poor serfaring mariners are with a snatch and away, but Horseman-SHIP hath rack and manger, so much at command, that provender pricks them, either to tilt or tourney, or long or short journey, and if good literature may be in a horse, then I am sure many of them are so well littered, and they are so proud of it, that morning and evening, the groom, hostler, or horse-keeper, are feign to smooth, cog and curry favour with them. It • was reported lately in a courant for current news, that a 
troop of French horse, did take a fleet of Turkish gallies, in the Adriatic sea, near the Gulf of Venice. 'The news was welcome to me, though I was in some doubt of the truth of it, but after I heard that the horses were shod with very thick cork; and I am sure I have heard of many impossibilities as true as that.

Of all living things, a horse hath the strangest burial being dead; for wolves, dogs, swines, kites, ravens, crows, and such beasts and birds, of prey and rapine, are commonly the living sepulchres of dead horses. And now I remember that thirty years since, I read of rich and magnificent funeral of a horse, which was the beloved palfrey of the famous Emperor Nero, and as near as I can, I will describe the manner of it.

This horse was a present sent to the Emperor from Naples to Rome, being a stately beast, in colour milk white, except here and there a small black spot, like a flea-biting, for which Nero caused him to be named Fleabitten Otho, for the love he bare to one Otho, a parasitical courtier, who was Emperor after him next except Galba ; in brief Nero took such a liking to the horse, that he vowed to the immortal gods, that if the beast died whilst he lived, he would have him buried with all the solemnity and funeral pomp as was becoming the horse of so great a monarch; and as fortune would have it, within some few months, the horse proved himself a mortal beast, yielding his breath into the air, his carcase being too compendious an abridgement or epitome for the magnitude or amplitude of his spirit.

All the college of horseleeches and farriers in Rome, were commanded to his emboweling, to see if in their mature wisdoms, they could find by the symptoms of what disêase he died. Every man spent his judgment; some said he died of a surfeit, having no measure of himself, being pampered with the delicate delights of the court; others said, that he understood of the oath which his master Nero had taken concerning his pompous burial, and therefore for very pride he died, to make his name famous by his obsequies. But there was one old horseleech that contradicted them all, and he did affirm 


\section{EARLY PROSE AND POETICAL WORKS.}

that he died of a heart grief and sudden melancholy, whereupon the stable-grooms were examined, who quickly cleared all doubts.

Truly said one of them, this skilful gentleman hath rightly guessed, for leading Fleabitten Otho to the water, after he had drunk a health to the Emperor, as he was coming back to the stable, two of the senator's horses met him, taking the wall of him, not giving him any reverence or dutiful respect, he being his Majesty's only favourite of a horse, for which disobedience of theirs, he presently fell sick, took his bed, made his will, and set his goods in such order as shall be declared.

When this news came to the Emperor, he being grieved for his horse, and offended with the two senators who had taught their jades no better manners than to take the wall of his Majesty's horse, he dismissed them from their offices, and made two of his own stable-grooms senators in their rooms, and after proceeded to the funeral of his horse, in manner and form following:

First, two hundred poor galled hackneys, and next three hundred labouring asses, all covered with black cotton, going two and two, every one having two bottles of hay on their backs, the only gift of the deceased; then a hundred hunting nags, and fifty coachhorses, with ten horses of state, with each two horse loaves for their diet bread. Then followed the plebeians in mourning habit, two hundred in number; next the stable-grooms, purveyors, clerks of the stable, farriers, horseleeches, and gentlemen of the stable, three hundred.

Then went the saddlers, charioteers, waggoners, carters, sumptermen, littermen, and coachmen, three hundred.

After them singers, Pagan Priests, flammines and Archflammines, seventy.

Then the hearse richly behung with escutcheons, devices, mottoes, and impresses.

After them the Emperor Nero chief mourner, and his train borne up by Otho and young Sporus.

Next went two old asses all in black velvet, as mourners of state or chevals de duel.

'Then followed Agrippina, Nero's mother, with the fair 
Poppaea, and the beautiful Acte, two of his concubines, and after them Galba Nimphidius Vitellius, with others. It is thought that Seneca sat all the while in his study, laughing at the funeral.

Lastly, a great troop of straggling attendants. The hearse being set down in Campus Martius, Otho began this speech which followeth, in blank verse.

INJURIOUs death, to make an emperor mourn Fleabitten Otho's timeless exequies, Who might have lived and borne great conquerors, And been the father of most valiant colts ; Lament, ye meeds, whereon this palfry grazed, $\mathrm{Ah}$ ! strew the streets of Rome with rotten hay. Let peas, beans, oats, and horse-bread must with grief, Rust curry-combs, and saddles rent in sunder, Break stirrup-leathers, girths, and bridle, break, Fall rack and manger, planks all in twain, For you shall ne'er support his weight again. You stable grooms that combed his crisped mane, And oft were graced to make up Otho's train, Sigh, groan, and weep, lament, and howl and cry, In litter and horse dung everlastingly. Think how brave Otho did his breath respire, Who with his heels had oft struck sparkling fire.

\section{Here Nero speaks.}

THe bravest beast that ever emperor backed, That thumped the field of Mars with greater grace Than $\cdot$ Pegasus bearing Tritonia

About the valleys near the Muses hill, In battle swifter than the northern wind, But in a triumph stout and full of state, Lifting his hoofs, as if he scorned the ground, And meant to make the air support his weight. As mannerly and moderate at his meat As is a bridegroom on his wedding day, H'or never would he touch a lock of hay, Or. smell unto a heap of provender Until he heard a noise of trumpet's sound, Whereby he knew our meat was served in. 


\section{EARLY PROSE AND POETICAL WORKS.}

But after meals, how he would meditate

Upon his tutor's reverend documents, And by himself would practise what was taught him, Offering to run the ring, and fetch curvets, To trot in state as we were on his back, And to out-do his schoolmaster in art; The thought of these things, Otho, kills my heart.

\section{Otho speaks to the two asses.}

'THen these poor animals have cause to weep ; Most reverend asses, you have lost a friend, A friend, a father have your worships lost, Who would have given you pensions in your age, And made you beadsmen, free from carriages. When he lay speechless, on his death bed, then He pointed to the hayloft with his heels, As who should say, if I die, give it them. Then to the wardens of his company, For he was made free of the blacksmith's craft, He turn'd about, bade them pull off his shoes, And take them as true tokens of his love. And as he dying showed his love to them, Because his master did delight in plays, He willed that of his mane should beards be made; And of his tail, a head-tire for a devil. One ass he made his sole executor, The other overseer of his will.

Grant Jupiter, they may perform the same To do and over-see, that men may say, They were just over-seers another day.

\section{Epitaph.}

Here lies the horse, whose four foot progeny

Did trot in blood before the walls of Troy;

Yea in the bowels of the Greek perdie, And on his breast this motto, Par ma foi, Kin, by the sire, to winged Pegasus, -And by the mother, to the king of mules Whose uncle was the great Bucephalus, Whose arms, four horse shoes, and the field was Gules. 
To conclude, this Horseman-SHIP after many storms, tempests, gusts, and flaws, came at last home to her ancient haven, the bear-garden, richly laden with these commodities following.

The Chinegall, the navegall, windgall, spurgall, lightgall, and shacklegall, the worms, the staggers, "the mallenders, and sallenders, scratches, pole-evil, the anticore, and the pompardye, the dropsy, the fever, the palsy, the glanders, the frenzy, the cough, and the coltevil, the yellows, the fashions, the splinters, the spavins, the ring-bones, the quitter-bones, the curbs, the rottenfrush, and the crown-scab, the hide-bound, the hawes, the crest-fall, the vives, the bloody riffs, the cramp, and the canker, the houghs, the toothache, the surfeit, the tongue-hurt, the paps, and the bladders, the tiredness, the lousiness, the surbate, the farcy, the pose, and the strangle, the broken-wind, the hoof-bound, the botch, the bots, the wen in the groin, the rot in the lungs, the kibes, the pearl, and the pin, and the webb, the cloyd, the blood-shot, the wrung in the withers, the strain, the prick in the sole, the loose in hoof, the gravel, the foundring, and the shedding of the hair, and the horsehipped, the wrench, the neckcrick, and the shoulder splat. These are the commodities wherewith the HorsemanShIP was freight, which are so shared and divided, that a man cannot light of any horse, young or old, but he is furnished with one, two, or more of these excellent gifts.

The ships that attended in the squadron or regiment with the Horseman-SHIP, were these.

1 The Race, an adventurous vessel of much expectation and admirable swiftness.

2 The Post, a vessel of much use, quick return, and exceeding hazard, toil and travel.

3 The Hackney, a most serviceable pinnace, that endures all weathers, and is so common that she is to be hired by any or used by all.

\section{THE SURETY-SHIP WITH HER REGIMENT.} THIs is a ship of great antiquity, and makes more 


\section{EARLY PROSE AND POETICAL WORKS.}

voyages than all the rest of the navy. She is the only merchant adventurer under the sun, for they that sail in her, do hazard goods, lands, money, reputation, friends, kindred, credit, liberty and life; of all which rich commodities, always at her returns, she is so provident, that she makes one jail or other her warehouse, where it is more safely kept under lock and key, than the golden apples of the Hesperides were guarded by the dragon. She is so easy to be boarded, that a man need not trouble his feet to enter her, or use any boat to come to her, for if all her mariners should go to her by water, then were a waterman the richest trade below the moon; only a dash with a pen, the writing of a man's name, passing his word or setting his mark, though it be but the form of a pair of pot hooks, a cross, a crooked billet, or a M. for John 'Tompson, any of these facile ways hath shipped a man into the Surety-SHIP, during his life and his heirs after him; and though the entrance into her be so easy, yet she is so full of impertinent and needy courtesy, that many men will lend a hand into her, with more fair entreaties, requests and invitations, than are commonly used to a mask at the court, or a gross of gossips in the country; and being once entered, a tenpenny nail driven to the head may as soon leap out of an oaken post, as a man may get ashore again. She is painted on the outside with vows and promises, and within her are the stories of the tattered prodigal, eating husks with the swine, the picture of Niobe, with Alecto, Tisiphone, and Megæra, dancing lacrymæ. Her arms are a goose quill or pen, couchant in a sheep-skin field fable, the motto above Noverint universi, the supporters a usurer, and a scrivener, the crest a Woodcock, the mantles red wax, with this other motto beneath, sealed and delivered, this ship hath the art to make parchment the dearest stuff in the world; for I have seen a piece little bigger than my two hands, that hath cost a man a thousand pound; I myself paid a hundred pound once for a small rotten remnant of it. She is rigged most strangely, her ropes and cables are conditions and obligations, her anchors are leases forfeited, her lead and line are mortages, her main sails are interchangeable in- 


\section{A NAVY OF LAND SHIPS.}

dentures, and her topsails bills and bonds, her small shot are arrests and actions, her great ordnance are extents, outlawries and executions : all her decks are struck with tenter-hooks, to hold those fast that enter her, her lading is locks, keys, bolts, shackles, manacles, fetters, grates, traps for vermin, gins for wild gulls, baits for tame fools, springs for woodcocks, pursenets for conies, toils for mad bucks, pens for geese, hooks for gudgeons, snares for buzzards, bridles for old jades, curbs for colts, pitfalls for bullfinches, and hempen-slips for asses, and besides all this, she is plentifully stored with want, hunger, cold, poverty and nakedness.

The ocean that she sails in, is the spacious Marshall Sea, sometimes she anchors at the Kingsbench, sometimes at the Gulf of the Gate-house, sometime at the White Lion Creek, sometimes at Newgate Road, sometimes at Ludgate Bay, sometimes at Wood-street Harbour, and sometimes at the Poultry Haven.

There is great reason to call a man being bound for another, Surety-SuIP, for a ship is an unruly beast, if she be not surely tyed, moored, and anchored, and therefore to be a. surety is as much to say ty-sure, the addition of the word ship, being a kind of metaphorical allusion, to the turbulent tossing of the unfortunate surety, upon the restless waves and billows of miserable varieties and mutabilities of time and trouble.

And though Surety-SHIP be, for the most part, prejudicial and baneful only to itself, yet as in the sea, the rising of one wave proceeds out of the fall of another; so one out of the ruins of Surety-SHIP wreck, like beetles or scarabs which breed out of dung, there do spring a swarm or generation of virtues, vipers I was about to say, as busy solicitors, nimble-tongued pettifoggers, greedy serjeants, hungry yeomen, devouring catchpoles, boisterous bailiffs, marshal's men merciless, dogged jailors and currish underkeepers; for as butchers trade is to live npon the slaughter of beasts, so cannot the kennels, litters and styes of those above-named anthropophagi or cannibals, live, eat, or subsist, but upon the confusion of men, and as a horse being dead in the fields and stripped, is a ban- 


\section{EARLY PROSE AND POETICAL WORKS.}

quet for dogs, hogs, ravens, kites, and crows, so is a surety to those vermins, who devour and prey upon his estate and carcase, both alive and dead.

But for conclusion of this blunt point, I think I have mistaken all this while in calling Surety-SHIP, for the consequence and success of the voyage will better allow it the name of sure ty sheep, which is a warning or document to ty the sheep sure, which I imagine to be a significant inversion of the word, for, as the bridle and harness of a live horse is for the most part made of the skin of a dead horse, so he that is bound for another man's debt, is like a silly innocent sheep, of which flock I may for my rank and calling be a bell-wether, with a bond of a dead sheep's skin tyed sure, as a sure tye, either to pay the debt, or surely he is sure to lye, if his ability help not, where I would be loth to be his bedfellow.

The ships and pinnaces that are in the regiment of the Surety-SHIP, are these: viz.

1 The Adventurous, a desperate hot ship, very hard to be guided or steered in any steady course.

2 The Kindheart, a ship that will sail any whither, or to what port a man would have her.

3 The Fool, a ship of great burthen, and for sail and steerage much like the Kindheart.

4. The Negligence, an argosy that through want of good foresight, brought the surety-ship in great danger.

5 The Decay, a ship much broken.

6 The Scape-thrift, a small ragged catch, that hangs or depends upon the whole regiment.

\section{THE WOR-SHIP WITH HER SQUADRON OR REGINEN'T.}

Though the first syllable of this ship's name be worse, whereby she is called Worse-SHip, yet she is a better ship than many are aware of, and indeed she is far too good for every, or for any knave to come aboard her. In my opinion she doth not belong to any mortal man, for God himself is both owner and master of her.

Yet many there are who claim an interest in her, as 
first the Devil would have her belong to him, for which cause he makes many barbarous nations to adore and Wor-SHIP him, and to sacrifice themselves, their children; and all that they esteem dearest unto them, to his infernal hell-hood, and for his better holding and keeping of this Wor-SHIP, he hath his ministers and agents, in the most kingdoms of christendom, who with their juggling legerdemain, hath gulled, blinded, and besotted many thousands of all estates, ages, sexes, that they will fall down and worship stocks, stones, blocks, idols, images, relics, dead men's bones, or a piece of bread, as the heathen idolatrous Egyptians did formerly adore and worship onions and garlic.

And as there are many that for desert are worthy pilots, steersmen and mariners in the Worship, and are shipped into ber only for their merits, so there are a great many, and more than a good many, that by falsehood and indirect courses, have shipped themselves in her; for as Cornelius Agrippa saith in his "Vanity of Sciences," some have gotten the worship by cutting throats in the wars; some by being great men's bawds, or cuckolds in peace; some for marrying cast stale concubine, or bastards; some by bribery, extortion or oppression; some by false weights and measures; some by excessive drunkenness of others; some by theft, some upon credit; some for ready money, and some for favour; which is a word crept into the place of merit since the days of Quintilianus the orator. 'The most corrupted justice will board her; the slothfulest divine will have a cabin in her; the carpet knight will be shipped in her; the most cowardly captain will enter her; and many of least faith and conscience will lay claim to her. She having store of such false owners, I say no more of her, but commit her to the mercy of wind, tide, and time.

There went with her in her regiment these that follow.

1 The Abuse, an old ship, too much in use.

2 The Purchase, a vessel all for si mony or ready money.

3 'The Mittimus, a dangerous bark, whose word is, "At your peril."

AEESE OF THE

UNIVERSITI

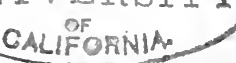




\section{EARLY PROSE AND POETICAL WORKS.}

\section{THE HUNTSMAN-SHIP, OR WOODMAN-SHIP, WITH HER SQUADRON OR REGIMENT.}

A GOoD huntsman is a good woodman, and a woodman is a mad man in the north parts of England, for when they think that a man is distracted or frenzy, they will say the man is wood, meaning mad, the reason why it is called Woodman-SHIP I take it to be thus derived, as first a ship hath a multiplicity of ropes, cordage, masts, rigging, and ground-tackle, which I have partly named before in the Lady-ship, so hath this Woodman-SHIP, divers and sundry terms of art, almost past numbering, as you must say rouse a buck, start a hare, and unkennel a fox. Again you must harbour a hart, and lodge a stag, or a buck; and in process of time always a hart or a buck do come to perfection, which many men, through imperfection, do never atttain to. As a buck is first a fawn, the second year a pricket, the third a sorel, the fourth a sore, the fifth a buck of the first head, and the sixth year a buck; so a hart is the first year a calf, the second a brocket, the third a spade, the fourth a staggard, the fifth a stag, and the sixth year a hart; but some are of the mind, that a stag cannot be a hart, until some king or prince have almost hunted his beart out. Besides these anbiguous, contigigrated phrases, the horns have many dogmatical epithets, as a hart hath the burrs, the pearls, the antlers, the surantlers, the royals, the surroyals, and the croches. A buck's horns are composed of burr, beam, branch, advancer, palm, and speller. And to decline from the crown or horn, to the rump or croupier; a deer, a boar, a hare, a fox, and a wolf, have no more tail than a jackanapes, for it is a deer's single, 'a boar's wrath, a hare or coney's scut, a fox's bush, and a wolf's stern. Besides there are most excellent terra-graphical and mundified names and titles; for that which is in Welsh a baw, in French. a marde, I could name it in English, but, Sir Reverence for that, in Woodman-ship, it is called a deer's fewmets, a boar or bear's leases, a hare or 'coney's croteys, a fox or a badger's fiants, and an otter's spraints, all which in English is a, T, \&c. I think Nimrod the great hunter would have been a mad man or a wood-man, if 
he had studied half the wild and hare-brained terms that belongs to this ship, and sure it made Actaeon horn-mad, in his too vehement pursuit of the game; for what necromantic spells are rut, vault, slot, pores and entries, abatures and foiles, frayingstocks, frith and fell, lairs, dewclaws, dowlcets, drawing the covert, blemishes, sewelling, avant-lay, allay, relay, foreloining, huntcounter, hunt-change, quarry, reward, and a thousand more such Utopian fragments of confused gibberish, that should I proceed further I should instead of an understanding wood-man, shew myself to be an ignorant mad man.

Is it not a worthy piece of service for five or six men in the country, whose dwellings are four or five miles asunder, to make a mad match, to meet together on such or such a morning to hunt or course a hare, where, if she be hunted with hounds, she will lead them such dance, that perhaps a horse or two are killed, or a man or two spoiled, or hurt with leaping hedges or ditches, at the least after four or five days preparation, and some ten pounds charge among men, horses, and dogs, besides an infinite deal of toil and trouble, and an innumerable number of oaths and curses. After this great deal of do, the main purchase can be no more than a poor silly hare, which is but a dry meat, and will take more butter in the basting, than her carcase is worth.

Our ancient progenitor or first king of this Island was so expert in this Woodman-SHIP, that he killed his own father Silvius, shooting him with an arrow, mistaking: him for a hart, a stag, or a buck; and William the Second, surnamed Rufus, King of England, was by the like mischance of a shot made at a deer, by Sir Walter Tyrrel, knight, slain with the glance of an arrow against a tree, in the New-forest in Hampshire.

I thank Cooper's Dictionary that tells me that Venator is a hunter, and Venatrix huntress, or a'woman hunting, and that Meretrix is a whore or a woman hunted. All these words having derivation from, or allusion to Venereus, alias Le-che-reus, for though Diana, the hunting goddess of chastity, be a constant Venatrix, yet 


\section{EARLY PROSE AND POETICAL WORKS.}

Venus the queen of love, never fails a right woodman of a Meretrix. But if Venator and Venatrix should hunt as much as Meretrix is, or hath been, hunted, I think verily that there hath not been, or in time would not be, one deer left in many of the greatest forests, parks, and chases of Christendom.

Besides, there is not a perfect mariner in the WoodmanSHIP, but he hath engrafted in him a most abundant gift of promising, for one of them will swear and vow to give more deer away to sundry persons, than there are under the keeping and command of six or seven of them; and I have heard, that one white buck in a small park, in a place which I could name within the walls of Christendom, hath been given away at least to a thousand several persons, by one keeper, and the said keeper is so kind, that he will never deny a buck to whosoever will ask. A deer-friend, whom I love dear, did promise me a deer four years since, and four dear journeys I made for my deer, and still with delays and demurs I was put off from my deer, with promises, that at such and such a time I should have my deer, but now I am in despair of my deer, and I mean to take no more care for my deer; and so adieu my deer; but indeed he that had the bounty to promise me this deer, hath the grace to blush whensoever he sees me, and therefore I do love him for his modesty and shamefacedness, and had it not been for that, and that I do love him indeed, I would long before this time have sung him a Kyrie-Eleison, that should have made him been glad to have promised me a brace of bucks more, to have stopped my mouth withal, although in performance my deer had been non est inventus.

In a word, of all sorts of deer I hold stolen venison to be the most honestly gotten because the thieves are so quiet, close, private, and silent at their work, that they have no leisure to swear or curse, as men do when it is lawfully taken, and my conceit is, that where oaths and curses are most restrained, there most honesty and piety remains. But commonly swearing, execrations, and 


\section{A NAVY OF LAND SHIPS.}

drinking, are the ceremonious rites of a buck's, or a hare's death and obsequies.

With the cry of the hounds,

And the echo resounds

Through the mead, through the fallow,

With the horn, with the hallow,

With the horse loud neigh, and the buck at a bay, And with the deer's fall, and the horn-sounding knell, My pen bids hunting Woodman-SHIP farewell.

The ships and pinnaces that served in the regiment under the Woodman-SHIP, were these.

1 The Chanter.

2 The Bowman.

3 The Ringwood.

4 The Slut.

5 The Beauty.

6 The Daisy.

7 The Killbuck, with divers others, all them being for course or cbase. 



\section{THE GREAT EATER}

$\mathrm{OF} \quad \mathrm{KENT}$

OR

PART OF THE ADMIRABLE

'TEETH AND STOMACH EXPLOITS.

OF

NICHOLAS WOOD, OF HARRISOON

IN THE COUNTY OF KENT.

His excessive

manner of eating without manners in strange and true manner described. 



\section{THE GREAT EATER OF KENT.}

RECORDS and histories do make memorable mention of the diversity of qualities of sundry famous persons, men and women, in all the countries and regions of the world, how some are remembered for their piety and pity; some for justice; some for severity, for learning, wisdom, temperance, constancy, patience, with all the virtues divine and moral. Some again, have purchased a memory for greatness and tallness of body; some for dwarfish smalluess; some for beautiful outsides, fair feature and composition of limbs and stature, many have gotten an earthly perpetuity for cruelty and murder, as Nero, Commodus, and others; for Lechery, as Heliogabalus; for drunkenness, Tiberius, alias Biberius; for effeminacy, as Sardanapalus; for gluttony, Aulus Vitellius, who at one supper was served with two thousand sorts of fishes, and seven thousand fowls, as Suetonius writes in his ninth book, and Josephus in his fitth book of the Jews wars. Caligula was famous for ambition, for he would be adored as a god, though he lived like a devil, poisoning his uncle, and deflowering all his sisters; and in all ages and countries, time hath still produced particular persons, men and women, either for their virtues or their vices, to be remembered, that by meditating on the good, we may be imitating their goodness, and by viewing the bad, we might be eschewing their vices.

T'o descend lower to more familiar examples, I have known a great man very expert on the Jew-harp; a rich heir excellent at Noddy; a justice of the peace skilled at quoits; a merchant's wife a quick gamester at Irish, especially when she came to bearing of men, that she would seldom miss entering. Monsieur La Ferr, a Frenchman, was the first inventor of the admirable game of double-hand, hot-cockles, and Gregory Dawson, an Englishman, devised the unmatchable mystery of blind-man'sbuff. Some have the agility to ride post, some the facility to run post; some the dexterity to write post, and some the ability to speak post. For I have heard a fellow make a Hackney of his tongue, and in a moment 
he hath galloped a lie from China to London, without bridle or saddle. Others do speak post, in a thick shuffing kind of ambling trot, and that in such speed, that one of them shall talk more in one quarter of an hour, than - shall be understood in seven years. And as every one hath particular qualities to themselves, and dissonant from others, so are the manners of lives, or livings, of all men and women various one from another; as some get their living by their tongues, as interpreters, lawyers, orators, and flatterers; some by tails, as maquerellaes, concubines, curtezans, or in plain English, whores; some by their feet, as dancers, lackeys, footmen, and weavers, and knights of the public or common order of the fork; some by their brains, as politicians, monopolists, projectmongers, suit-joggers, and star-gazers; some like the. salamander live by fire, as the whole race of Tubal Cain, the vulcanean brood of blacksmiths, firemen, colliers, gunners, gun-founders, and all sorts of metal-men; some like the chameleon, by the air, and such are poets, trumpeters, cornets, recorders, pipers, bagpipers; and some by smoke, as tobacconists, knights of the vapour, gentlemen of the whiff, esquires of the pipe, gallants in fumo; some live by the water as herrings do, such are brewers, vintners, dyers, mariners, fishermen, and scullers; and many like moles live by the earth, as griping usurers, racking landlords, toiling ploughmen, moiling labourers, painful gardeners, and others.

Amongst all these before mentioned, and many more which I could recite, this subject of my pen is not for his quality, inferior to any; and as near as I can, I will stretch my wit upon the tenters, to describe his name and character, his worthy acts shall be related after in due time duly.

And, be it known unto all men, to whom these presents shall come; that I John Taylor, waterman of Saint Saviours in Southwark, in the county of Surrey, the writer hereof, etc., will write plain truth, bare and threadbare, and almost stark-naked-truth, of the descriptions, and remarkable, memorable actions of Nicholas Wood, of 
the Parish of Harrisom in the County of Kent, yeoman, for these considerations following:

First, I were to blame to write more than truth, because that which is known to be true, is enough.

Secondly, that which is only true, is too much.

Thirdly, the truth will hardly be believed, being so much beyond man's reason to conceive.

Fourthly, I shall run the hazard to be accounted a great liar, in writing the truth.

Lastly, I will not lie, on purpose to make all those liars that esteem me so.

Yet by your leave, Master Critic, you must give me license to flourish my phrases, to embellish my lines, to adorn my oratory, to embroider my speeches, to interlace my words, to draw out my sayings, and to bumbast the whole suit of the business for the time of your wearing. For though truth appeareth best bare in matter's of justice, yet in this I hold it decent to attire her with such poor rags as I have, instead of robes.

First then, the place of his birth and names of his parents are to me a mere terra incognita, as far from my knowledge as content from a usurer, or honesty from a bawd; but if he be no Christian, the matter is not much, he will serve well enough for a man of Kent; and if his education had been as his feeding, it is evident he had been of most mighty breeding. He hath gotten a foul name, but I know not if it came to him by baptism, for it is partly a nick-name, which in the total is Nicholas, I would abate him but a saint, and call him Nicholas Shambles, and were the goodness of his purse answerable to the greatness of his appetite, out of all question, no man below the moon would be a better customer to a shambles than he; for though he be chaste of his body, yet his mind is only upon flesh, he is the only Tugmutton or Muttonmonger betwixt Dover and Dunbar; for he hath eaten a whole sheep of sixteen 'shillings price, raw at one meal; pardon me, I think he left the skin, the wool, the horns and bones. But what talk I of a sheep, when it is apparently known that he hath at one repast and with one dish, feasted his carcase with all manner of 


\section{EARLY PROSE AND POETICAL WORKS.}

meats? All men will confess that a hog will eat any thing, either fish, flesh, fowl, root, herb, or excrement, and this same noble Nick Nicholas, or Nicholas Nick hath made an end of a hog all at once, as if it had been but a rabbit sucker, and presently after for fruit to recreate his palate, he hath swallowed three pecks of damsons, thus philosophically, by way of a chemical infusion, as a hog. will eat all things that are to be eaten, so he in eating the hog did in a manner of extraction distil all manner of meats through the limbeck of his paunch.

But hold a little, I would be loath to cloy my reader with too much meat and fruit at once, so that after your sheep, hog, and damsons, I think it best to suffer you to pause and pick your teeth, if you have any, whilst I spend a few words more in paraphrasing upon his surname. Wood is his appellation, denomination, or how you please to term it.

Some of the ancient philosophers have compared men to a tree with the bottom upwards, whose root is the brain, the arms, hands, fingers, legs, feet and toes, are the limbs and branches. The comparison is very significant; many trees do bring forth good fruit, so do some few men. Some stately trees grow high and fair, yet stand for nothing but shades, and some men grow high and lofty, yet are nothing but shadows. Some trees are so malignant that nothing can prosper under the compass of their branches; and some men are so unlucky, that very few can thrive in their service. And as of one part of a tree a chair of state may be made, and of another a carved image, and of a third a stool of office, so men, being compounded and composed all of one mould and metal, are different and disconsonant in estates, conditions, and qualities. Too many, like the barren fig-tree, bear leaves of hypocrisy; but no fruits of integrity, who serve only for a flourish in this life, and a flame in that hereafter.

So much for that. Now to return to my theme of Wood; indeed this last digression may make my reader think that I could not see wood for trees, what wood he is I know not, but by his face he should be Maple or 
Crabtree, and by his stomach sure he is heart of Oak; some say he is a Meddler, but by his stature he seems like a low short Pine, and certain I am that he is Popular, a well-timbered piece, or a store-house for belly timber.

Now gentlemen, as I have walked you amongst the trees and through the wood, I pray sit down and take a taste or two more of this banquet.

What say you to the leaf or fleck of a brawn new killed, to be of weight eight pound, and to be eaten hot out of the boar's belly raw? much good do you gallants, was it not a glorious dish? and presently after, instead of suckets, twelve raw puddings. I speak not one word of drink all this while, for indeed he is no drunkard, he abhors that swinish vice. Alehouses nor tapsters cannot nick this Nick with froth; curtal cans, tragical black-pots, and double-dealing bumbasted jugs, could never cheat him, for one pint of beer or ale is enough to wash down a hog, or water a sheep with him.

Two loins of mutton and one loin of veal were but as three sprats to him. Once at Sir Warham Saint Ledger's house, and at Sir William Sydleye's he shewed himself so valiant of teeth and stomach, that he ate as much as would well have server and sufficed thirty men, so that his belly was like to turn bankrupt and break, but that the serving-men turned him to the fire and anointed his paunch with grease and butter to make it stretch and hold; and afterwards being laid in bed, he slept eight hours and fasted all the while; which when the knight understood, he commanded him to be laid in the stocks, and there to endure as long time as he had lain bedrid with eating.

Pompey the Great, Alexander the Great, Tamberlane the Great, Charlemagne or Charles the Great, Arthur the Great, all these gat the title of great for conquering kingdoms and killing of men; and surely eating is not a greater sin than rapine, theft, manslaughter and murder. Therefore this noble Eatalian doth well deserve the title of Great; wherefore I instile him Nicholas the Great, Eater. And as these forenamed greats have overthrown 


\section{EARLY PROSE AND POETICAL WORKS.}

and wasted countries and hosts of men, with the help of their soldiers and followers, so hath our Nick the Great, in his own person, without the help or aid of any man, overcome, conquered, and devoured in one week as much as would have sufficed a reasonable and sufficient army in a day, for he hath at one meal made an assault upon seven dozen of good rabbits at the Lord Wottons in Kent, which in the total is fourscore, which number would well have sufficed a hundred, three-score, and eight hungry soldiers, allowing to each of them half a rabbit.

Bell, the famous idol of the Babylonians, was a mere impostor, a juggling toy, and a cheating bauble, in comparison of this Nicholaitan Kentish Tenterbelly, the high and mighty Duke All-paunch, was but a fiction to him. Milo the Crotonian could hardly be his equal, and Woolner of Windsor was not worthy to be his footman. A quarter of fat lamb and threescore eggs have been but an easy collation, and three well larded pudding-pies he hath at one time put to foil, eighteen yards of black puddings, London measure, have suddenly been imprisoned in his souse-tub. A duck raw, with guts, feathers, and all, except the bill and the long feathers of the wings, hath swam in the whirlpool or pond of his maw, and he told me that three-score pound of cherries was but a kind of washing meat, and that there was no tack in them, for he had tried it at one time. But one John Dale was too hard for him at a place called Lennam, for the said Dale had laid a wager that he would fill Wood's belly with good wholesome victuals for two shillings, and a gentleman that laid the contrary did wager that as soon as noble Nick had eaten out Dale's two shillings, that he should presently enter combat with a worthy knight called Sir Loin of. Beef, and overthrow him; in conclusion, Dale bought six pots of potent, high, and mighty ale, and twelve new penny white loaves, which he sopped in the said ale, the powerful fume whereof conquered the conqueror, robbed him of his reason, bereft him of his wit, violently took away his stomach, intoxicated his Pia Mater, and entered the sconce of his Pericrauium, blind-folded him with sleep; setting a nap 
of nine hours for manacles upon his thread-bare eyelids, to the preservation of the roast beef, and the unexpected winning of the wager.

This invincible ale, victoriously vanquished the vanquisher, and over our great triumpher, was triumphant. But there are precedents enough of as potent men as our Nicholas, that have subdued kings and kingdoms, and yet they themselves have been captured and conquered by drink. We need recite no more examples but the Great Alexander,and Holofernes; their ambition was boundless, and so is the stomach of my pen's subject, for all the four elements cannot cloy him, fish from the deepest ocean, or purest river, fairest pond, foulest ditch, or dirtiest puddle, he hath a receipt for fowl of all sorts, firom the wren to the eagle, from the titmouse to the ostrich or cassowary, his paunch is either a coop or a rocst for them. He hath within himself a stall for the ox, a room for the cow, a sty for the hog, a park for the deer, a warren for conies, a store-house for fruit, a dairy for milk, cream, curds, whey, butter-milk, and cheese ; his mouth is a mill of perpetual motion, for let the wind or the water rise or fall, yet his teeth will ever be grinding; his guts are the rendezvous or meeting place or burse for the beasts of the fields, the fowls of the air, and fishes of the sea; and though they be never so wild or disagreeing in nature, one to another, yet he binds or grinds them to the peace, in such manner, that they never fall at odds again. His eating of a sheep, a hog, and a duck raw, doth shew that he is free from the sin of niceness or curiosity in his diet. It had been happy for the poor, if their stomachs had been of that constitution, when sea coals were so dear here. Besides, he never troubles a larder, or cupboard to lay cold meat in, nor doth he keep any cats or traps in his house to destroy vermin, he takes so good a course, that he lays or shuts up all safe within himself; in brief, give him meat, and he ne'er stands upon the cookery; he cares not for the peacock of Samos, the woodcock of Phrygia, the cranes of Malta, the pheasants of England, the capercailzie, the heathcock, and ptarmigan of Scotland, the goat of Wales, the salmon, and usquebaugh of Ire- 


\section{EARLY PROSE AND POETICAL WORKS.}

land, the sausage of Bolognia, the skink of Westphalia, the Spanish potatoe, he holds as a bauble, and the Italian fig he esteems as poison.

$\mathrm{He}$ is an Englishman, and English diet will serve his turn. If the Norfolk dumpling, and the Devonshire whitepot, be at variance, he will atone them, the bag-puddings of Gloucestershire, the black-puddings of Worcestershire, the pan-puddings of Shropshire, the white puddings of Somersetshire, the hasty puddings of Hampshire, and the pudding-pies of any shire, all is one to him, nothing comes amiss, a contented mind is worth all, and let any thing come in the shape of fodder, or eating stuff, it is welcome, whether it be sausage, or custard, or egg-pie, or cheese-cake, or flawn, or fool, or froise, or tansy, or pancake, or fritter, or Alapjack, or posset, galley-mawfrey, mackeroon, kickshaw, or tantablin, he is no pulling meacock, nor in all his life time the queasyness of his stomach needed any saucy spur or switch of sour verjuice or acute vinegar, his appetite is no straggler, nor is it ever to seek, for he keeps it close prisoner, and like a courteous kind jailor, he is very tender over it, not suffering it to want any thing if he can by any means procure it; indeed it was never known to be so far out of reparations, that it needed the assistance of candle, aleberry, julep, cullis, gruel, or stewed-broth, only a mess of plain frugal country pottage was always sufficient for him, though it were but a washing-bowl full, of the quantity of two pecks, which pottenger of his, I myself saw at the sign of the White Lion at a village called Jarrisom, in Kent, the hostess of which house did affirm, that he did at once wash down that bowl full of pottage, with nine penny loaves of bread, and three jugs of beer.

Indeed, in my presence, after he had broken his fast, having, as he said, eaten one pottle of milk, one pottle of pottage, with bread, butter, and cheese. I then sent for him, to the aforesaid inn, and after some accommodated salutations, I asked him if he could eat anything? He gave me thanks, and said, if he had known, that any gentleman would have invited him, that he would have spared his breakfast at home, and with that he told me 
as aforesaid, what he had eaten; yet nevertheless, to do me a courtesy, he would shew me some small cast of his office, for he had one hole or corner in the profundity of his store-house, into which he would stow or bestow any thing that the house would afford, at his peril and my cost. Whereupon I summoned my hostess with three knocks upon the table, two stamps on the floor with my fist and foot, at which she made her personal appearance with a low curtsy, and inquisitive "what lack ye?" I presently laid the authority of a bold guest upon her, commanding that all the victuals in the house should be laid on the table. She said, she was but slenderly provided, by reason goodman Wood was there, but what she had, or could do, we should presently have. So the cloth was displayed, the salt was advanced, six penny wheaten loaves were mounted two stories high like a rampier, three sixpenny veal pies, walled stifly about, and well victualed within, were presented to the hazard of the Scalado, one pound of sweet butter, being all fat and no bones, was in a cold sweat at this mighty preparation, one good dish of thornback, white as alabaster or the snow upon the Scithian mountains, and in the rear came up an inch thick shiver of a peck household loaf; all which provision were presently, in the space of an hour utterly confounded, and brought to nothing, by the mere and only valourous dexterity of our unmatchable grand Gormand. He courageously passed the pikes, and I cleared the shot, but the house yielded no more, so that my guest arose unsatisfied, and myself discontented in being thrifty and saving my money against my will.

I did there offer him twenty shillings to bring him up to me to my house on the Bankside, and there I would have given him as much good meat, as he would eat in ten days, one after another, and five shillings a day every day, and at the ten days end, twenty shillings more, to bring him down again. I did also offer ten shillings to one Jeremy Robinson, a glover, a man very inward with him, to attend and keep him company, and two shillings sixpence the day, with good diet and lodging; all which were once accepted, until Wood began to ruminate and 


\section{EARLY PROSE AND POETICAL WORKS.}

examine what service he was to do, for these large allowances. Now my plot was to have him to the Beargarden, and there before a house full of people, he should have eaten a wheel-barrow full of tripes; and the next day, as many puddings as should reach over the Thames, at a place which I would measure betwixt London and Richmond; the third day, I would have allowed him a fat calf, or sheep of twenty shillings price; and the fourth day he should have had thirty sheeps gathers; thus from day to day he should have had wages and diet with variety; but he fearing that which his merits would amount unto, brake off the match, saying, that perhaps when his Grace, I guess who he meant, should hear of one that eat so much, and could work so little, he doubted there would come a command to hang him; whereupon our hopeful Bear-garden business was shivered, and shattered in pieces.

Indeed he made a doubt of his expected performance in his quality, by reason of his being grown in years, so that if his stomach should fail him publicly, and lay his reputation in the mire, it might have been a disparagement to him for ever, and especially in Kent, where he hath long been famous, he would be loth to be defamed; but as weak as he was, he said that he could make a shift to destroy a fat wether of a pound in two hours, provided that it were tenderly boiled, for he hath lost all his teeth, except one, in eating a quarter of mutton, bones and all, at Ashford in the county aforesaid; yet is he very quick and nimble in his feeding, and will rid more eating work away in two hours, than ten of the hungriest carters in the parish where he dwells. He is surely noble, for his great stomach, and virtuous chiefly for his patience in putting up much; moreover he is thrifty or frugal, for when he can get no better meat, he will eat ox livers, or a mess of warm ale-grains from a brew-house. He is provident and studious where to get more provision as soon as all is spent, and yet he. is bountiful or prodigal in spending all he hath at once. $\mathrm{He}$ is profitable in keeping bread and meat from mould and maggots, and saving the charge of salt, for his appetite 
will not wait and attend the poudering; his courtesy is manifest, for he had rather have one farewell than twenty goodbyes. Of all things, he holds fasting to be a most superstitious branch of Popery, he is a main enemy to Emberweeks, he hates Lent worse than a butcher or a Puritan, and the name of Good-Friday affrights him like a bul-beggar; a long grace before meat strikes him into a quotidian ague ; in a word, he could wish that Christmas would dwell with us all the year, or that every day were metamorphosed into Shrove-Tuesdays; in brief, he is a magazine, a store-house, a receptacle, a burse, or exchange, a babel or confusion for all creatures.

$\mathrm{He}$ is no gamester, neither at dice or cards, yet there is not any man within forty miles of his head that can play with him at Maw, and though his pasture be ever so good, he is always like one of Pharaoh's lean kine; he is swarty, blackish hair, hawk-nosed like a parrot or a Roman, he is wattle-jawed, and his eyes are sunk inward, as if he looked into the inside of his entrails to note what customed or uncustomed goods he took in, whilst his belly, like a mainsail in a calm, hangs ruffled and wrinkled, in folds and wrathes, flat to the mast of his empty carcase, till the storm of abundance fills it, and violently drives it into the full sea of satisfaction.

LIKE as a river to the ocean bounds, Or as a garden to all Britain's ground, Or like a candle to a flaming link, Or as a single ace, unto sife Cinque, So short am I of what Nick Wood hath done, That having ended, I have scarce begun. For I have written but a taste in this, To show my readers where, and what he is. 

THREE WEEKS, THREE DAYS, AND THREE HOURS

\section{OBSERVATIONS AND TRAVELS}

\section{FROM LONDON TO HAMBURG}

\section{AMONGST JEWS AND GENTILES}

\section{WITH}

Descriptions of Towns and Towers, Castles and Citadels; Artificial Gallowses and Natural Hangmen.

And dedicated for the present, to the absent Odcombian Knight Errant, Sir Thomas Coriat, Great Britain's Error and the World's Mirror. 


\section{EARLY PROSE AND POETICAL WORKS.}

To the Cosmographical, Geographical Describer, Geometrical Measurer; Historiographical, Caligraphical Relater and Writer; Enigmatical, Pragmatical, Dogmatical Observer, Engrosser, Surveyor and Eloquent British Grecian Latinist, or Latin Grecian Orator, the Odcombian Deambulator, Perambulator, Ambler, Trotter, or untired Traveller,

Sir Tho. Conyat, Knight of Troy, and one of the dearest darlings to the blind Goddess Fortune.

Most worthy Sir, as Quintilian in his apothegms to the naked, learned Gimnosophists of Ethiopia, very wittily says, Potanto Machayo corbatio monomosco kayturemon Lescus, Ollipuffitingere whingo, which is, knowledge is a main antithesis to ignorance, and pains and travel is the highway to experience. I being therefore well acquainted with the generous urbanity innated or rooted in your humanity, in these days of vanity, I dedicate out of my affability, debility, ability, imbecility, facility on agility, this poor pamphlet to your nobility, in all servility and humility; not doubting but the fluent secundity of your wisdom's profundity, in your head's rotundity, will conserve, reserve preserve, and observe, what I and my industrious labours deserve. I do, out of mine own cognition, aver and abet that he is senseless that will assent, that the Fates did assign with their whole assistance, that any should aspire to be an associate in any assembly, boldly to assimulate, assay, assault, or ascribe to any mortal but yourself, superlative majority or transcendency for travels, observations, and oratory. These things being revolved and ruminated in the sagacity or acuteness of my pericranium, I imagined that no man under the cope was more worthy than yourself to be a patronizing poplar to shelter my poor reed-like endeavours. Howsoever in the preterlapsed occurrences there hath been an antagonistical repugnancy betwixt us, yet I hope time and travel hath worn it thread-bare, or brought it to an irrecoverable consumption; withal I know you are incapable of inexpungable malice, inveterate malignancy or emulation. I protest tongue-tied taciturnity should have imprisoned this work in the lethargical dungeon or 
bottomless abyss of ever-sleeping oblivion, but that I am confident of your patronage and acceptance, which if it fall out, not according to any promerits of mine, but out of mine own expectation of your matchless and unparalleled disposition, I shall hereafter sacrifice whole hecatombs of invention both in prose and verse, at the shrine of your unfellowed and unfollowed virtues. So wishing more to see you than to hear from you, because writers want work and the press is turned voluntary through the scarcity of employments, which I hope your presence will supply, I pray that Neptine, Aolus, Tellus Bacchus, and all the watery, windy, earthly and drinking: deities may be officious, auspicious, and delicious unto you, humbly imploring you to take in good part this my sophistical, paradoxical submission, with a mental reservation of my love and service, to sympathize or be equivalent to your kind liking and corroborated affecting.

He that hath a poor muse to trot in your service with all obsequious observance.

JOHN TAYLOR.

\section{THREE IVEEKS, THREE DAYS, AND THREE HOURS OBSERVATIONS, FROM LONDON TO HAMBURG IN GERMANY.}

Amongst Jews and Gentiles, with Descriptions of Towns and Towers, Castles and Citadels, artificial Gallowses, Natural Hangmen :

And dedicated for the present, to the absent Odcombian Knight Errant, Sir Thomas Coryat.

Great Britain's Error, and the world's Mirror.

Upon Saturday the 17 th of August 1616, after I had taken leave of some friends that would hardly give me leave to leave them, I was associated with five or six courteous comrades to the haven of Billingsgate, where I was no sooner come but I was shipped in the wherry for the port of Gravesend, and having two women and three men in my company thither, we past the way away by telling tales by turns. Where one of the women took 


\section{EARLY PROSE AND POETICAL WORKS.}

upon her very logically to defend the honesty of brokers, and she maintained her paradoxical arguments so pithily, as if herself like a desperate pawn had lain seven years in lavender on sweeting in Long Lane, or among the dogged inhabitants of Houndsditch. And one of the men replied that he thanked God he never had any need of them, whereupon I began to suspect him to be a crafty knave, because the proverb says, "A crafty knave needs no broker," and indeed after I had enquired what countryman he was, he told me he was a Welsh man, and a Justice's clerk. I left him as I found him, hoping never to be troubled with his binding over and withdrawing; and so landing at Gravesend, we all went to the Christopher, where we took a bacchanalian farewell one of another, where I remained till the Mouday following, awaiting the coming down of the ship that I was to be transported in. About the hour of three in the afternoon, with good hope we weighed anchor, and with a courteous tide and gentle wind we sailed down the river of Thames as far as the grand oyster haven of Queenborough, where though our ship was not sea-sick, yet she cast, anchor I mean.

On the morrow, being Tuesday, we weighed, and with the friendly breath of Zephyrus, alias a western wind, our sails being swollen, our ship called the Judith, who with her stern cut the liquid mounting mountains of Neptune's wavering territories, as nimbly as Hebrew Judith beheaded Holofernes. So that by the bountiful favour of Him that rules both winds and seas, the Thursday following we espied the coast of Friesland, and the next day we sailed by an island called the Holy Land, which may be called the land of lobsters, or the country of crabs, for the plenty of those kind of crawling creatures that are taken there. But we, taking time by the fore-top, let no advantage slip, but with a merry gale, and a friendly flood, on the Friday we sailed up the river of Elve, as far as Stoad, where we anchored till the morrow, being Saturday, and the feast of St. Bartholomew the apostle, we arrived at a bleak, alias a town an English mile írom Hamburg, called Altonagh, which is so called by the 
Hamburgers because it stands all-too-nigh them for their profit, being inhabited with divers tradesmen which do hinder their freedom. I was no sooner landed there, but my company and myself went to a Dutch drinkingschool, and having upse-freez'd four pots of boon beer as yellow as gold, our host said we had four shilling to betail, or to pay, which made me suspect it to be a bawdy house by his large reckoning, till at last I understond that the shillings he meant were but stivers, or three-halfpence a piece. So this terrible shot being discharged, which in the total amounted to the sum of sixpence English, we departed towards Hamburg, where by the way 1 noted some twenty men, women, and children in divers places of Altonagh, all deformed, some with one eye, some with hare-lips, crooked-backed, splay-footed, half-nosed, or one blemish or other. I admiring at them, was told they were Jews, wherein I perceived the judgment of the High Judge of all, that had permitted nature to deform their forms, whose graceless minds were so much misshapen through want of grace.

But I being entered the city of Hamburg on the Saturday, I was presently conducted to the English house, where I found a kind host, an honest hostess, good company, store of meat, more of drinks, a true tapster, and sweet lodging. And being at dinner, because I was a stranger, I was promoted to the chiefest place at the table, where to observe an old custom, every man did his best endeavour to hance me for my welcome, which by interpretation is, to give a man a loaf too much out of the brewers basket, in which kind of potshot, our English are grown such stout proficients, that some of them dares bandy and contend with the Dutch their first teachers. But after they had hanced me as well as they could, and I pleased, they administered an oath to me, in manner and form as followeth:

\section{Laying my hand on a full pot,}

I swear by these contents and all that is herein contained, that by the courteous favour of these gentlemen, I do find myself sufficiently hanced, and that henceforth I shall acknowledge it; and that whensoever I shall offer 


\section{EARLY PROSE AND POETICAL WORKS.}

to be hanced again, I shall arm myself with the craft of a fox, the manners of a hog, the wisdom of an ass, mixed with the civility of a bear. This was the form of the oath, which as near as I can shall be performed on my part; and here is to be noted that the first word a nurse or a mother doth teach her children if they be males, is drink, or beer. So that most of them are transformed to barrels, firkins, and kilderkins, always freight with Hamburg beer.

And though the city is not much more than half the bigness as London is within the walls, yet are there in it almost 800 brewhouses, and in one day there hath been shipped away from thence, 337 brewings of beer, besides 13 or 14 brewings have been racked or stayed in the town, as not sufficient to be bezzled in the country.

The Saturday being thus past, and Sunday come, I went toward the English Church, where I observed many shops open, buying and selling, chopping and changing of all manner of wares, with the streets furnished with apples, pears, plums, nuts, grapes, or any thing else that an ordinary market can afford, as commonly as if the Sabbath were but a bare ceremony without a commandment. In which I note the Jews in their execrable superstition, to be more devout and observant, than these pedlars in their profession; for on the Saturday, being the Jews Sabbath, they neglect all human affairs, and betake themselves irreligiously to their misbelieving faithless religion.

The sermon being ended at the English Church, I walked in the afternoon with a friend of mine, an inhabitant of the town, to see and to be seen, where at one of the gates was placed a strong guard of soldiers with muskets, pikes, halberts, and other warlike accoutrements. I asked the cause, and I was informed it was because of the building of new mounts and bulwarks which were partly erected without the old wall; and when I perceived these fortifications, I was amazed, for it is almost incredible, for the number of men and horses that are daily set on work about it besides the work itself is so 
great that it is past the credit of report, and as I suppose will prove most inexpugnable and invincible rampiers to strengthen the town on that side against the invasive attempts of the greatest monarch that should assail them.

But after much musing, walking further towards the fields, I espied four or five pretty parcels of modesty go very friendly up into a Council-house by the way side, as we and thousands of people used to pass; they were handsome young girls of the age of 18 or 20 years apiece, and although they had a door to shut, yet they knowing their business to be necessary and natural, sat still in loving and neighbourly manner. So having traced a turn or two we returned into the town again, and entering a long garden within the walls, some of the townsmen were shooting for wagers at a mark with their muskets, some bowling, some at slide-thrift or shovel-board, some dancing before a blind fiddler, and his cow bellied, dropsy, dirty, drab. Some at one game, some at another, most of them drinking, and all of them drunk, that though it was a Sabbath, which should wholly be dedicated to God, yet by the abuse of these bursten-gutted bibbers, they made it an afternoon consecrated, or more truly execrated to the service of Hell, and to the great amplification of the Devil's kingdom.

When Christians dare God's Sabbath to abuse, They make themselves a scorn to Turks and Jews.

You stealing Barabasses beastly race,

Rob God of glory, and yourselves of grace.

Think on the supreme Judge who all things tries,

When Jews against you shall in judgment rise.

Their feigned truth, with fervent zeal they show, The truth unfeigned you know, yet will not know.

Then at the bar in New Jerusalem,

It shall be harder much for you than them. * But leaving to their drunken designs, I returned toward my lodging, where by the way I saw at the common jail of the town, a great number of people were clustered together. I asked the cause of their concourse, and I was certified that there was a prisoner to be broken upon the wheel the next day, and that these idle gazers did press 


\section{EARLY PROSE AND POETICAL WORKS.}

to gape upon him for want of better employments. I being as inquisitive after novelties, as a traveller of my small experience might be, enquired earnestly the true cause of the next day's execution. My friend told me that the prisoner was a poor carpenter dwelling in the town, who lately having stolen a goose, and plucking it within his doors, a little girl, his daughter-in-law, went out of his house, and left the door open, by which means, the owner of the goose passing by, espied the wretched thief very diligently picking what he before had been stealing, to whom the owner said: Neighbour, I now perceive which way my geese use to go, but I will have you in question for them, and so away he went. The caitiff being thus reproved grew desperate, and his child coming into his house: ye young whore, quoth he, must ye leave my door open for folks to look in upon me? and with that word, he took a hatchet and with a cursed stroke, he clove the child's head; for the which murder he was condemned and judged to be broken alive upon the wheel. Close by the jail I espied a house of free stone, round and flat roofed, and leaded, upon the which was erected the true picture of a most unmatchable hangman. And now I am entered into a discourse of this brave abject, or subject, you must understand that this fellow, is a merry, a mad, and a subsidy hangman, to whom our Tyburn tatterdemalion, or our Wapping wind-pipe stretcher, is but a raggamuffin, not worth the hanging; for this tear-throat termagant is a fellow in folio, a commander of such great command, and of such greatness to command, that I never saw any that in that respect could countermand him; for his making is almost past description. No Saracen's head seems greater, and sure I think his brainpan if it were emptied, as I think he hath not much brain in it, would well contain half a bushel of malt, his shaggy hair and beard would stuff a cushion for Charon's boat, his embossed nose and embroidered face, would furnish a jeweller; his eyes well dried, would make good tennisballs, or shot for a small piece of ordnance, his yawning mouth would serve for a cony-burrow, and his two ragged rows of teeth, for a stone wall, or a pale; then hath he a 
neck like one of Hercules his pillars, with a wind-pipe, or rather a beer pipe, as big as the boar of a demiculvering, or a wooden pump; through which conduit half a brewing of Hamburg beer doth run down into his unmeasurable paunch, wherein is more midriff, guts and garbage than three tripe-wives could be able to 'utter before it stunk. His post-like legs were answerable to the rest of the great frame which they supported, and to conclude, Sir Bevis, Ascapart, Gogmagog, or our English Sir John Falstaff, were but shrimps to this bezzling bombard's longitude, latitude, altitude, and crassitude, for he passes, and surpasses the whole German multitude.

And as he is great in corpulency, so is he powerful in potency, for figuratively he hath spiritual resemblance of Romish authority, and in some sort he is a kind of demipope; for once a year in the dog-days he sends out his men with baits instead of bulls, with full power from his greatness to knock down all the curs without contradiction, whose masters or owners will not be at the charge to buy a pardon for them of his mightiness, which pardon is more durable than the pope's of wax or parchment, for his is made of a piece of the hide of an ox, a horse, or such lasting stuff, which with his stigmatical stamp or seal is hanged about every dog's neck who is fireed from his fury by the purchase of his pardon. And sure I am persuaded that these dogs are more sure of their lives with the hangman's pardon, than the poor besotted, blinded papists are of their seduced souls from any pardon of the pope's.

The privileges of this grand halter-master are many, as he hath the emptying of all the vaults or draughts in the city, which no doubt he gains some favour by. Besides all oxen, kine, horses, hogs, dogs, or any such beasts, if they die themselves, or if they be not like to live, the hangman must knock them on the heads and have their skins; and whatsoever inhabitant in his jurisdiction doth any of these things aforesaid himself, is abhorred and accounted as a villain without redemption. So that with hangings, headings, breakings, pardoning and killing of dogs, flaying of beasts, emptying of vaults, and such privy 
commodities, his whole revenue sometimes amounts to four or five hundred pounds a year. And he is held in that regard and estimation, that any man will converse and drink with him; nay sometimes the lords of the town will feast with him, and it is accounted no impeachment to their honours ; for he is beld in the rank of a gentleman, or a rank gentleman, and he scorns to be called in the cast weeds of executed offenders. No, he goes to the mercer's and hath his satin, his velvet, or what stuff he pleases, measured out by the yard or the ell, with his gold and silver lace, his silk stockings, lace spangled garters and roses, hat and feather, with four or five brave villains attending him in livery cloaks, who have stipendiary means from his ignominious bounty.

Monday the 19th of August, about the hour of twelve at noon, the people of the town in great multitudes flocked to the place of execution, which is half a mile English without the gates, built more like a sconce than a gallows, for it is walled and ditched about with a drawbridge, and the prisoner came on foot with a divine with him, all the way exhorting him to repentance, and because death should not terrify him, they had given him many rouses and carouses of wine and beer. For it is the custom there to make such poor wretches drunk, whereby they may be senseless either of God's mercy or their own misery; but being prayed for by others, they themselves may die resolutely, or, to be feared, desperately.

But the prisoner being come to the place of death, he was by the officers delivered to the hangman, who entering his strangling fortification with two grand hangmen more and their men, which were come from the city of Lubeck and another town which I cannot name, to assist their Hamburgian brother in this great and weighty work. The drawbridge was drawn up, and the prisoner mounted on a mount of earth, built high on purpose that the people without may see the execution a quarter of a mile round about. Four of the hangman's men take each of them a small halter, and by the hands and the feet they hold the prisoner's extended all abroad lying on his back. 'Then the arch-hangman, or the great 
master of this mighty business took up a wheel, much about the bigness of one of the fore wheels of a coach, and first, having put off his doublet, his hat, and being in his shirt, as if he meant to play at tennis, he took the wheel and set it on the edge and turned it with one hand like a top or a whirligig. Then he took it by the spokes, and lifting it up with a mighty stroke he beat one of the poor wretch's legs in pieces, the bones I mean, at which he roared greviously; then after a little pause he breaks the other leg in the same manner, aud consequently breaks his arms, and then he struck four or five main blows on his breast and burst all his bulk and chest in shivers; lastly, he smote his neck, and missing, burst his chin and jaws to mammocks. Then he took the broken mangled corpse and spread it on the wheel, and thrust a great post or pile into the nave or hole of the wheel, and then fixed the post into the earth some six feet deep, being in height above the ground some ten or twelve feet, and there the carcase must lie till it be consumed by all-consuming time or ravening forvls.

This was the terrible manner of this horrid execution, and at this place are twenty posts with those wheels or pieces of wheels, with heads of men nailed on the top of the posts, with a great spike driven through the skull. The several kinds of torments which they inflict upon offenders in those parts makes me to imagine our English hanging to be but a flea-biting.

Moreover, if any man in those parts is to be beheaded, the fashion is that the prisoner kneels down, and being blinded with a napkin, one takes hold of the hair of the crown of the head, holding the party upright, whilst the hangman with a backward blow with a sword will take the head from a man's shoulders so nimbly and with such dexterity, that the owner of the head shall never want the miss of it. And if it be any man's fortune to be hanged for never so small a crime, though he be mounted whole, yet he shall come down in pieces, for he shall hang till every joint and limb drop one from another.

They have strange torments and varieties of deaths, 
according to the various nature of offences that are committed; as for example, he that counterfeits any prince's coin and is proved a coiner, his judgment is to be boiled to death in oil, not thrown into the vessel all at once, but with a pulley or a rope to be hanged under the arm pits and let down into the oil by degrees. First the feet, and next the legs, and so to boil his flesh from his bones alive. For those that set houses on fire wilfully, they are smoked to death; as first there is a pile or post fixed in the ground, and within an English ell of it is a piece of wood nailed cross, whereupon the offender is made fast fitting, then over the top of the post is whelmed a great tub of dry fat, which doth cover or overwhelm the prisoner as low as the middle. Then underneath the executioner hath wet straw, hay, stubble, or such kind of stuff, which is fired, but by reason it is wet and dank, it doth not but smoulder and smoke, which smoke ascends up into the tub where the prisoner's head is, and not being able to speak he will heave up and down with his belly, and people may perceive him in these torments to live three or four hours.

Adultery there, if it be proved, is punished with death, as the loss of both the parties heads if they be both married, or if not both, yet the married party must die for it, and the other must endure some easier punishment, either by the purse or carcase, which in the end proves little better than half a hanging.

But as after a tempest a calm is best welcome, so I imagine it not amiss after all this tragical, harsh discourse, to sweeten the reader's palate with a few comical reports which were related unto me, wherein I seem fabulous, it must be remembered that I claim the privilege of a traveller, who hath authority to report all that he hears and sees, and more too. I was informed of a fellow that was hanged somewhat near the highway, within a mile or two of Collein, and the fashion being to hang with a halter and a chain, that when the halter is rotten with the weather, the carcase drops a button-hole lower into the chain. Now it fortuned that this fellow was executed on a winter's afternoon towards night, and being hanged, 
the chain was shorter than the halter, by reasons whereof he was not strangled, but by the jamming of the chain which could not slip close to his neck, he hanged in great torments under the jaws; it happened that as soon as he was trussed up, there fell a great storm of rain and wind, whereupon all the people ran away from the gallows to shelter themselves. But night being come and the moon shining bright, it chanced that a country boor, or a waggoner and his son with him were driving their empty waggon by the place where the fellow was hanged, who being not choked, in the extremity of his pains did stir his legs and writhe and crumple his body, which the waggoner's son perceived and said, "Father, look, the man upon the gallows doth move." Quoth the old man, " he moves indeed, I pray thee let us make haste and put the waggon under the gribbet to see if we can unhang and save him." This being said was quickly done, and the wretch half dead was laid in straw in the boor's waggon and carried home, where with good attendance he was in four or five days recovered to his health, but that he had a crick in his neck, and the cramp in his jaws. The old man was glad that he had done so good a deed, as he thought, began to give the thief fatherly comusel, and told him that it was God's great mercy towards him to make me, quoth he, the instrument of thy deliverance, and therefore look that thou make good use of this his gracious favour towards thee, and labour to redeem the time thou hast misspent; get thee into some other prince's country, where thy former crimes may not bring thee into the danger of the law again, and there with honest, industrious endeavours get thy living.

The thief seemed willng to entertain these good admonitions, and thanked the boor and his son, telling them that the next morning he would be gone; and if ever his fortunes made him able, he promised to be so grateful unto them that they should have cause to say their great courtesies were well bestowed upon him. But all his sugared sweet promises, were in the proof but gall and wormwood in the performance, for this graceless caitiff arose betimes in the morning, and drew on a pair 


\section{EARLY PROSE AND POETICAL WORKS.}

of boots and spurs which were the man's son's of the house, and slipping out of the doors, went to the stable and stole one of his kind host's best horses, and away rode he. The man and his son, when they were up and missed the thief and the horse, were amazed at the ingratitude of the wretch, and with all speed bis son and he rode several ways in pursuit of him, and in brief one of them took him, and brought him back to their house again; and when it was night they bound him, and laid him in their waggon, having deaf ears and hardened hearts to all his entreaties, and away to the gallows where they found him hanging, there they, with the halter being a little shortened, they left him. The next day the country people wondered to see him hanging there again, for they had seen him hanged, and missed him gone, and now to be thus strangely and privately come again in boots and spurs, whereas they remembered at his first hanging he had shoes and stockings, it made them muse what journey he had been riding, and what a mad ghost he was to take the gallows for his inn, or as I suppose, for his end.

The rumour of this accident being bruited abroad, the people came far and near to see him, all in general wondering how these things should come to pass. At last, to clear all doubts, proclamations were published with pardon, and a reward to any that could discover the truth, whereupon the old boor and son came in and related the whole circumstances of the matter.

At another place, the hangman's place being void, there were two of the blood, for it is to be noted that the succession of that office doth lineally descend from the father to the son, or to the next of the blood, which were at strife for the possession of this high indignity. Now it happened that two men were to be beheaded at the same town, and at the same time, and to avoid suit in law for this great prerogative, it was concluded by the arbitrators, that each of these new hangmen should execute one of the prisoners, and he that with greatest cunning and sleight could take the head from the body, should have the place. To this they all agreed, and the prisoners were brought forth, where one of the executioner's did bind a 
red silk thread double about his prisoner's neck, the threads being distant one from another only the breadth of one thread, and he promised to cut off the head with a backward blow with his sword, between the threads. The other called his prisoner aside, and told him if he would be ruled by him, he should have his life saved, and besides, quoth he, I shall be sure to have the office. The prisoner was glad of the motion, and said he would do anything upon these conditions. Then said the hangman, when thou art upon thy knees, and hast said thy prayers, and that I do lift up my axe, for I will use an axe, to strike thee, I will cry hem, at which word do thou rise and run away. Thou knowest none will slay thee if thou canst once escape after thou art delivered into my custody; it is the fashion of our country, and let me alone to shift to answer the matter. This being said or whispered, the headsman with the sword did cut off the prisoner's head just between the threads as he had said, which made all the people wonder at the steadiness of his hand, and most of them judged that he was the man that was and would be most fittest to make a mad hangman of.

But as one tale is good till another be told, and as there be three degrees of good, better, and best; so this last hangman did much exceed and eclipse the other's cunning. For his prisoner being on his knees, and he lifting up his axe to give the fatal blow, hem, said he according to promise, whereupon the fellow arose and ran away; but when he had run some seven or eight paces, the hangman threw the axe after him, and struck his head smoothly from his shoulders. Now for all this, who shall have the place is unknown, for they are yet in law for it; and I doubt not but before the matter be ended, that the lawyers will make them exercise their own trades upon themselves to end the controversy. This tale doth savour somewhat hyperbolical, but I wish the reader to believe no more of the matter than I saw, and there is an end.

At another town there stood an old over-worn despised pair of gallows, but yet not so old but they will last many 


\section{EARLY PROSE AND POETICAL WORKS.}

a fair year with good usage, but the townsmen a little distance from them built another pair, in a more stately germetrical port and fashion, whereupon they were demanded why they would be at the charge to erect a new gallows, having so sufficient an old one. They answered, that those old gallows should serve to hang: fugitives and strangers; but those new ones were built for them and their heirs for ever. Thus much for hangmen, thieves, and gallowses.

Yet one thing more for thieves. In Hamburg those that are not hanged for theft, are chained two or three together, and they must in that sort, six or seven years draw a dung-cart, and cleanse the streets of the town, and every one of those thieves for as many years as he is condemned to that slavery, so many bells he hath hanged at an iron above one of his shoulders, and every year à bell is taken off, till all are gone, and then he is a free man again, and I did see ten or twelve of these carts, and some of the thieves had seven bells, some five, some six, some one, but such a noise they make, as if all the devils in hell were dancing the morrice.

Hamburg is a free city, not being subject to the Emperor or any other Prince, but only governed by twenty-four Burgomasters, whereof two are the chief, who are called Lords, and do hold that dignity from their first election during their lives. The buildings are all of one uniform fashion, very lofty and stately ; it is wonderful populous, and the water with boats comes through most of the streets of the town.

'Their churches are most gorgeously set forth, as the most of them covered with copper, with very lofty spires, and within sides they are adorned with crucifixes, images and pictures, which they do charily keep for ornaments, but not for idle or idol adornation. In Saint Jacob's and in Saint Katherine's churches there is in one of them a pupil of alabaster, and in the other a pair of such organs, which for worth and workmanship are unparalleled in christendom, as most travellers do relate.

'The women are no fashion mongers, but they keep in their degrees one continual habit, as the richer sort do 
wear a huke, which is a robe of cloth or stuff plaited, and the upper part of it is gathered and sewed together in the form of an English potlid with a tassel on the top, and so put upon the head, and the garment goes over her ruff and face if she please, and so down to the ground, so that a man may meet his own wife, and perhaps not know her from another woman.

'They have no porters to bear burdens, but they have big burly-boned knaves with their wives that do daily draw carts any whither up and down the town, with merchant's goods or any other employments. And it is reported that these cart-drawers are to see the rich men of the town provided of milch-nurses for their children, which nurses they call by the name of Ams, so that if they do want a nurse at any time, these fellows are cursed, because they have not gotten wenches enough with child to supply their wants.

But if a man of any fashion do chance to go astray to a house of iniquity, the whilst he is in the house at his drudgery, another of the whores will go to the sheriff, which they call the right-heir, and inform that such a man is in such a suspected house; then is his coming forth narrowly watched, and he is taken and brought before the right-heir and examined, where it he be a man of credit, he must and will pay forty, fifty, or sixty rex-dollars hefore he will have his reputation called in question. Of which money the quean that did inform shall have her reward.

A lawyer hath but a bad trade there, for any cause or controversy is tried and determined in three days, quirks, quiddits, demurs, habeas corpuses, sursararaes, procedendoes, or any such dilatory law-tricks and abolished, and not worth a button.

But above all, I must not forget the rare actions and humours of a quacksalver or mountebank, or to speak more faniliarly, a shadow a skilful chirurgeon. 'This fellow being clad in an ancient doublet of decayed satin, with a spruce leather jerkin with glass buttons, the rest of his attire being correspondent, was mounted upon the scaffold, having shelves set with vials, gallipots, glasses, 


\section{EARLY PROSE AND POETICAL WORKS.}

boxes, and such like stuff, wherein as he said, were waters, oils, unguents, emplasters, electuaries, vomits, purges, and a world of never heard of drugs; and being mounted, as I said, he and his man began to proclaim all their skill and more, having a great number of idle and ignorant gazers on, he began as followeth, as I was informed by my interpreter, for I understood not one word he spake.

I, Jacomo Compostella, practitioner in physic, chirurgery, and the mathematics, being a man famous through Europe, Asia, Africa, and America, from the oriental exaltation of Titan to his occidental declination, who for the testimony of my skill and the rare cures that I have done, have these prince's hands and seals. At first, the great Cham of Tartaria, in whose court only with this water which is the Elixir of Henbane, diafracted in a diurnal of ingredients Hippocratontic, Avicenian, and Cataract, with this did I cure the great Duchess of Promulpho of the cramp in her tongue; and with this oil did I restore the Emperor Gregory Evanowich of a convulsion in his pericranion. From thence I travelled to Slavonia, where I met with Mustapha, Despot of Servia, who at that time was intolerably vexed with a Spasmus, so that it often drove him into a syncope with the violent obstructions of the conflagerating of his veins. Only with this precious unguent, being the quintessence of Mugwort with Auripigmenty, terrographicated in a limbeck of crystalline translucency, I recovered him to his former health, and for my reward I had a Barbary horse with rich caparisons, a Turkish scimitar, a Persian robe, and 2000 Hungarian ducats.

Besides, here are the hands and seals of Potohamock, Adelantado of Prozewgma, and of Gulch Flownderscurfe, chief burgomaster of Belgrade, and of divers princes and estates, which to avoid tedious prolixity I omit. But good people if you or any other be troubled with apoplexies, palsies, cramps, lethargies, cataracks, quinsies, tisick, pleurisies, coughs, headaches, tertian, quartan, and quotidian agues, burning fevers, jaundices, dropsies, colics, illiaca passio's, the stone, the strangury, the pox, 
plague, botches, biles, blains, scabs, scurfs, mange, leprosies, cankers, megrims, mumps, fluxes, measles, murrains, gouts, consumptions, toothache, ruptures, hernia. aquosa, hernia ventosa, heruia carnosa, or any other malady that dares afflict the body of man or woman, come and buy while you may have it for money, for I am sent for speedily to the Emperor of Trapezond, about affairs of great importance that highly concerns his royal person.

Thus almost two hours did this fellow with embost words and most laborious action, talk and swear to the people, that understood no more what he said, than he himself understood himself. And I think his whole takings for simple compounds did amount in the total to ninepence sterling.

But leaving Hamburg, having gathered these few observations aforesaid, out of it I went, August 28th, and my first jaunt of iny travels was by water, to a town called Buckstahoo. It is a little walled town and stands on the other side of the river, three miles as they call it from Hamburg. The boat we passed in is called an Iuar, not so good as a Gravesend barge, yet I think it may be as great, and the three miles longer than from London to Gravesend, for I am sure that we were going nine hours before we could be landed. Our passage cost us threepence a piece, and one thing I remember well, that the lazy watermen will sit still all, or the most part of the way, whilst their passengers, be they never. so rich or poor, all is one to them, be they men or women, they must row by turns an hour or such a matter. And we landed in the night at a place called Crants, where all the passengers were to go to supper, but such diet we had that the proverb was truly verified, "God sent meat, and the devil sent"cooks." For as there was no respect of persons in the boat, so all fellows at the table, and all one price, the palatine and the plebian. Our first mess was great platters of black broth, in shape like new tar, and in taste cousin german to slut pottage ; our second were dishes of eels, chopped as small as herbs, and the broth they were in as salt as brine; then had we a 


\section{EARLY PROSE AND POETICAL WORKS.}

boiled goose, with choak pears and carrots buried in a deep dish; and when we demanded what was to pay, it was but threepence a man. I mused at the cheapness of it, but afterwards they came upon us with a fresh reckoning of fivepence a man for beer, for they never count their meat and drink together, but bring in several reckonings for them. But the morning being come, we hired a boor's waggon to carry us to a place called Citezen, three miles there, or twelve English miles from Buckstahoo, a little bald dorp it is, where we came about noon, and found such slender entertainment that we had no cause to boast of our good cheer or our hostess's cookery. We having refreshed ourselves and hired a fresh waggon, a way we went two miles further to a dorp called Rodonburg. 'This village belongeth to the Bishop of Rodonburg, who hath a fair house there, strongly walled and deeply ditched and moated about, very defensible, with draw-bridges and good ordnance. This bishop is a temporal lord, notwithstanding his spiritual title; and no doubt but the flesh prevails above the spirit with him; so the Bishops of Breame, Lunninburg, and divers other places in Germany, do very charitably take the fleece, for they themselves never look to the flock, by reason they use no ecclesiastic function, but only in name.

Being lodged at Rodonburg, in a stately inn, where the host, the hostess, guests, cows, horses, sivine lay all in one room yet I must confess their beds to be very good, and their linen sweet; but in those parts they use no coverlet, rug, or blanket, but a good featherbed undermost, with clean sheets, pillows, and pillowbears, and another featherbed uppermost, with a fair sheet above all, so that a man's lodging is like a womau's lying-in, all white.

August the 30th we went from Rodenburg, and about noon we came to an old walled town, called Feirden. It hath two churches in it, and the hangman's statue very artificially carved in stone, and set on a high pillar with a rod rampart in his hand. At this town I met with six strangers, all travellers, where we went to dinner together, 
all at one table, and every man opened his knapsack or budget with victuals; for he that carries no ineat with him, may fast by authority in most places of that country. But to note the kinduess of these people one to an ither, some had bread and a box of salt butter, some had raw bacon, some had cheese, some had pickled herring, some dried beef, and amongst the rest I had brought three ribs of roastbeef, and other provision from Hamburg. 'T'o conclude, we drew all like fiddlers, and fed, for the most part, like swine, for every man eat what was his own, and no man did proffer one bit of what he had to his neighbour; so he that had cheese must dine with cheese, for he that had meat would offer him none. I did cut every one a part of my roast beef; which my guide told me they would not take well, because it is not the fashion of the comntry. I tried, and found them very tractable to take anything that was good, so that I perceived their modesty to take one from another, proceeds from their want of mamners to offer. But dimner being done, away we went over a bridge, in the midst whereof is a cage, made in the likeness of a great lanthorn. It is hanged on a turning gibbet like a crane, so that it may be turned on the bridge and over the river, as they shall please that have occasion to use it. It is big enough to hold two men, and it is for this purpose - if any one or more do rob gardens or orchards, or cornfields, if they be taken, he or they are put into this same whirligig, or kickambob, and the gibbet being turned, the offender hangs in this cage from the river some 12 or 14 feet from the water, and then there is a small line made fast to the party some 5 or 6 fathom, and with a trick which they have, the bottom of the care drops out, and the thief falls suddenly into the water. I had not gone far, but at the end of the bridge I saw an old chapel, which in old time they say was dedicated to St. Frodswick, which hath the day after Saint Lnke the Evangelist. I entering in, perceived it was a charitable chapel, for the doors and windows were always open, by reason there were none to shut, and it was a common receptacle for beggars and rogues. 'There was the imrge of our lady with a veil over her, made as I think of a 


\section{EARLY PROSE AND POETICAL WORKS.}

baker's bolter, and Saint Peter holding a candle to her. I cut a piece of her veil, and taking Peter by the hand at my departure, the kind image, I know not upon what acquaintance, being loose handed, let me have his hand with me, which being made of wood, by reason of ruinous antiquity, burst off in the handling; which two precious relics I brought home with me to defend me and all my friends from sparrow-blasting.[?]

From this place we were glad to travel on foot 1 Dutch mile to a dorp called Dufurn, where we hired a boor's waggon to a town Neinburg; but we could not reach thither by 2 English miles, so that we were glad to lodge in a barn that night. On the morrow early we arose and came to Neinburg, which is a little walled town, belonging to that Bishopric from whence it is so named. There we staid 3 hours before we could get a waggon; at last we were mounted to a dorp called Leiz, 2 Dutch miles. I would have bargained with the boor to have carried us to Dorn, which I bade my guide tell him it was but a mile further. A mile quoth the boor, indeed we call it no more, but it was measured with a dog, and they threw in the tail and all to the bargain; so to Leiz he carried us, and there we found a waggon of Dorn homeward bound, which made us ride the cheaper; but it was the longest mile that ever I rode or went, for surely it is as much as some ten of our miles in England. But having overcome it at last, from thence I took a fresh waggon to carry me two miles to a town called Buckaburg, where I had and have I hope a brother residing, to whom my journey was intended, and with whom my perambulation was at a period. This town of Buckaburg is wholly and solely belonging to the Graff or Grave of Shomburg, a prince of great command and eminence, absolute in his authority and power, not countermanded by the Emperor, or any other further than courtesy requires; and in a word, he is one of the best accomplished gentlemen in Europe for his person, port, and princely magnificence. He hath there to his inestimable charge, built the town, with many goodly houses, streets, lanes, a strong wall, and a deep ditch, all well furnished 
with munition and artillery, with a band of soldiers which he keepeth in continual pay, allowing every man a dollar a week, and double apparel every year. Besides, he hath built a stately church, being above 120 steps to the roof; with a fair pair of organs, a curious carved pulpit, and all other ornaments belonging to the same. His own palace may well be called an earthly paradise, which if I should run into the praise of the description of, I should bring my wits into an intricate labyrinth, that I should hardly find the way out, yet according to the imbecility of my memory I will only touch a little at the shadow of it, and let the substance stand where it doth.

At the front or outward gate is a most stately arch, upon the top whereof is erected the image of Envy, as great as a demi Colossus, between two dragons, all gilt with gold. Before the gate is an iron grate to open and shut as it were of flower's or work of embroidery, at which gate stands always a court of guard, and a sentinel, and at the lower part of the arch is the Prince's title, or in capital letters as followeth:

\section{ERNESTUS DEI GRATIA COMES HOLST, Scomburgh, Sternburgh, \&c.}

After I was entered within the outward gate, I was shewed his stables, where I saw very fair and goodly horses, both for war and other uses. Amongst the rest there was one naturally spotted like a leopard or panther, and is so called by the name of leopard,--a stately courageous beast, and so formed as if nature had laid all her cunning aside, only to compose that horse; and indeed I must acknowledge he was made for the service of some great prince, and not for any inferior person.

Passing further, I came to another court of guard, and over a draw-bridge into the inner court, where on the right hand I was conducted into the chapel, in which chapel, if it were possible that the hand of mortal men, with artificial workmanship, could visibly set forth the magnificent glory of the immortal Creator, then absolutely there it is ; but being impossible so to do, as near as I can, 


\section{EARLY PROSE AND POETICAL WORKS.}

I will describe it. The pavement is all of black and grey marble, curiously wrought with chequer-work; the seats and pews are carved wainscoat of wonderful cunning and workmanship; the roof is adorned with the statues of angels and cherubims, many in number, all so richly gilded as if gold were as plentiful as pewter, there could not be more liberality bestowed. Besides there are a fair set of organs, with a brave sweet choir of choristers, so that when they sing, the lutes, viols, bandoraes, organs, recorders, sacbuts, and other musical instruments all strike up together with such a glorious, delicious harmony as if the angelical music of the spheres were descended into that earthly tabernacle. The prince himself is a Protestant, very zealous in his prayer, and diligent in his attention to the preacher, who although I understood not, yet I perceived he was a good divine, who gravely and sincerely, with reverence and eloquent elocution, delivered the bread of life to the understanding auditors.

In this town I staid with my brother from Saturday, the last of August, till the Thursday following, which was the fifth of September. When I was conducted an English mile on my way by certain of my countrymen, my lord's musicians, where we drank and parted, only my brother and my guide brought me that night to a strong walled town called Minden, which standeth on the river of Weazar, and belongeth to the bishop of that See. On the morrow I walked to see the town, where I bought thirty-six cheeses for eightpence, and a yard and a balf of pudding for fivepence, which I brought into England for rarities. So about noon we took a boat to pass down the river, which boat is much longer than any western barge, but nothing near so broad. It was half laden with lime and chalk, and by reason the wind blew hard, we were almost choked with the flying and scattering. of that dusty commodity. Besides the water was so shallow, that we ran a-ground three or four times, and sometimes an hour, sometimes less before we could get afloat again, which made me and my guide go ashore at a village called Peterhaghen, where we hired a waggon to Leize, where we stayed all night, being come into our old way 
again, where were a crew of strolling rogues and whores that took upon them the name of Egyptians, jugglers, and fortune-tellers; and indeed one of them held the good wife with a tale, and whilst another was picking her chest, and stole out ten dollars which is forty shillings, and she that talked with her looked in her hand, and told her that if she did not take great heed she knew by her art that some mischance was near her; which proved true, for her money was gone the whilst her fortune was telling.

But I appointed a waggon over night to be ready by three of the clock in the morning, when I arose and applied my travel so hard by changing fresh waggons, so that that day I came as far as Rodenburg, which was nine Dutch miles, where I stayed that night. The next day being Sunday the eighth of September, we took waggon towards Buckstahoo. We had a merry boor, with an hundred tatters about him; and now I think it fit a little to describe these boors, their natures, habits, and unmannerly manners. In our English tongue the name boar or boor do truly explain their swinish condition, for most of them are as full of humanity as a bacon-hog, or a boar, and their wives as cleanly and courteous as sows. For the most part of the men they are clad in thin buckrum, unlined, bare legged and footed, neither band nor scarce shirt, no woollen in the world about them, and thus will they run through all weathers for money by the waggon side, and though no better apparelled, yet all of them have houses, land, or manual means to live by. The substantial boors I did meet 120 of them that Sunday, with every one a hatchet in his hand. I mused at it, and thought they had been going to fell wood that day, but my guide told me they were going to church, and that instead of cloaks they carried hatchets, and that it was the fashion of the country. Whereupon it came into my mind, cloak, quasi cleave-oak, ergo the boors wear hatchets instead of cloaks.

There are other fashion boors, who wear white linen breeches as close as Irish trousers, but so long that they are turned up at the shoe in a roll like a maid's sleeves at 


\section{EARLY PROSE AND POETICAL WORKS.}

the hand, but what these fellows want in the bigness of their hose, they have in doublets, for their sleeves are as big as breeches, and the bodies great enough to hold a kilderkin of beer, and a barrel of butter.

The country is very full of woods, and especially oaks, which they very seldom cut down, because of the mast for their swine, which live there in great abundance. If any man be slain or murdered in the way, they use to set up a wooden cross in the place, for a memorial of the bloody fact committed there, and there were many of those wooden crosses in the way as I travelled.

They seldom have any robbery committed amongst them, but there is a murder with it; for their unmannerly manner is to knock out a man's brains first, or else to lurk behind a tree, and shoot a man with a piece or a pistol, and so make sure work with the passenger, and then search his pockets.

It is as dangerous to steal or kill a hare in some places there, as it is to rob a church or kill a man in England, and yet a twopenny matter will discharge the offender, for the best and the worst is but an halter; and I was informed that an English merchant, not knowing the danger, as he was riding on the way, having'a piece charged in his hand, as it is an ordinary weapon to travel with there, by chance he espied a hare, and shot at her and killed her; but he was apprehended for it, and it was like to have cost him his life ; but before he got out of the trouble, he was fain to use his best friends and means, and pleading ignorance for his innocency, at last with the loss of a great deal of liberty and five hundred pounds in money, he was discharged. The reason of this strict course is because all the hares in the country do belong to one lord or other, and being in abundance, they are killed by the owner's appointment, and carried to the markets by cart loads, and sold for the use of the honourable owners. And no boor or tenant that dwells in those parts where those hares are plenty, must keep a dog except he pay five shillings a year to the lord, or else one of his fore-feet must be cut off, that he may not hunt hares. 
A man is in almost as high proportion to be a knave in England as a knight in Germany, for there a gentleman is called a youngcur, and a knight is but a youngcur's man, so that you shall have a scurvy squire command a knight to hold his stirrup, pluck off his boots, or any other unknightly piece of service. And verily I think there are an hundred several princes, earls, bishops, and other estates, that do every one keep a mint, and in their own names stamp money, gold, silver, and brass; and amongst twenty-three twopence's which I had of their brass money, which they call grushes, I had thirteen several coins.

Many more such worthy injunctions and honourable ordinances I observed, which are hardly worth pen and ink the describing, and therefore 1 omit them, and draw towards an end, for on the Wednesday morming I was at an anchor at Stoad, and on the Friday night following, I was, by God's gracious assistance, landed at London. So that in three weeks and three days I sailed from England to Hamburg and back again, staying in the country seventeen days, and travelled two hundred miles by land there; gathering like a busy bee all these honeyed observations, some by sight, some by hearing, some by both, some by neither, and some by bare supposition. 

A

\section{VERY MERRY-WHERRY-FERRY VOYAGE}

OR

\section{YORK FOR MY MONEY}

Sometimes Perilous and sometimes Quarrelous

Performed with a pair of oars by sea from London By John Taylor and Job Pennell

AND WRITTEN BY J. T. 


\section{AS MUCH HAPPINESS AS MAY BE WISHED ATTEND}

THE TWO HOPEFUL IMPS OF GENTILITY AND LEARNING, Mr. RICHARD AND GEORGE HATTON.

You forward pair, in towardly designs, To you I send these soused, salt-water lines ; Accept, read, laugh, and breathe, and to't again, And still my muse, and I, shall yours remain.

JoHN TAYLOR.

\section{PROLOGUE.}

I now intend a voyage here to write, From London unto York, help to indite Great Neptune lend thy aid to me, who past Through thy tempestuous waves with many a blast, And then I'll true describe the towns and men, And manners, as I went and came again. 


\section{A VERY MERRY-WHERRY-FERRY VOYAGE;}

\section{OR, YORK FOR MY MONEY.}

THE year which I do call as others do,

Full 1600, adding twenty-two. ${ }^{a}$

The month of July that's for ever fam'd,

Because 'twas so by ${ }^{b}$ Julius Cæesar nam'd,

Just when six days, and to each day a night,

The dogged dog-days had began to bite,

On that day which dost blest remembrance bring,

The name of an apostle, and our king,

On that remarkable good day, Saint James,

I undertook my voyage down the Thames.

The sign in Cancer, ${ }^{d}$ or the ribs and breast,

And Æolus blew sweetly, west south-west.

Then atter many farewells, cups and glasses,

Which oftentimes hath made men worse than asses,

About the waist ore navel of the day,

Not being dry or drunk, I went my way.

Our wherry somewhat old, or struck in age,

That had endur'd near four year's pilgrimage,

And carried honest people, whores, and thieves,

Some sergeants, bailiffs, and some ${ }^{f}$ under-sheriffs,

And now at last it was her lot to be

Th' adventurous bonny bark to carry me.

But as an old whore's beauty being gone

Hides nature's wreck with art, like painting on,

a. The year of our Lord.

b. July was named so by Caesar.

c. The dogdays were six days entered.

So I with colours finely did repair

My boat's defaults, and made her fresh and fair.

Thus being furnish'd with good wine and beer, And bread and meat, to banish hunger's fear, With sails, with anchor, cables, sculls, and oars, With card and compass, to know seas and shores, With lanthorn, candle, tinder-box and match, And with good courage, to work, ward, and watch, Well man'd, well ship'd, well victual'd, well appointed, Well in good health, well timbered and well jointed,

d. I observe signs, winds, tides, days, hours, times, situations, and manners.

e. Noon if you'll like it so.

f. Boats are like barber's chairs, hackneys, or whores: common to all estates. 


\section{EARLY PROSE AND POETICAL IVORKS.}

All wholly well, and yet not half-fox'd well, 'Twixt Kent and Essex, we to Gravesend fell. There I had welcome of my friendly host, A Gravesend trencher, and a Gravesend toast, Good meat and lodging at an easy rate, And rose betimes, although I lay down late. Bright Lucifer, the messenger of day, His burnished, twinkling splendour did display; Rose cheek'd Aurora hid her blushing face, She spying Phobus coming gave him place, Whilst Zephyrus and Auster, mix'd together, Breath'd gently, as foreboding pleasant weather. Old Neptune had his daughter 'Thames supplied, With ample measure of a flowing tide; But Thames supposed it was but borrowed goods, And with her ebbs, paid Neptune back his floods. Then at the time of this auspicious dawning, I roused my men, who scrubbing, stretching, yawning, Arose, left Gravesend, rowing down the stream, And near to Lee, we to an anchor came. Because the sand were bare, and water low, We rested there, till it two hours did flow; And then to travel went our galley-foist, Our anchor quickly weigh'd, our sail soon hoist, Where thirty miles we past, a mile from shore,

g. These flat sands are called the Spits.
The water two $0^{g}$ foot deep, or little more.

Thus past we on the brave East Saxon Coast

From three at morn, till two at noon almost, By Shoebury, Wakering, Foulness, Tillingham, And then we into deeper water came. There is a crooked bay runs winding far, To Maldon, Estreford, and Colchester, Which cause 'twas much about, to ease men's pain, I left the land, and. put into the main. With speed, the crooked way to scape and pass, I made out straight for Frinton and the Nass. But being three leagues then from any land, And holding of our main-sheet in my hand, We did espy a coal-black cloud to rise, Forerunner of some tempest from the skies; 
Scarce had we sail'd a hundred times our length, But that the wind began to gather strength. Stiff Aolus with Neptune went to cuffs ; With huffs and puffs, and angry counter-buffs, From boisterous gusts, they fell to fearful flaws, Whilst we 'twixt wind and water, near death's jaws, Tost like a cork upon the mountain main, Up with a whiff, and straightway down again, At which we in our minds much troubled were, And said, God bless us all, what weather's here? For, in a word, the seas so high did grow, That ships were forc'd to strike their topsails low. Meantime, before the wind, we scudded brave, Much like a duck, on top of every wave. But nothing violent is permanent, And in short space away the tempest went. So farewell it; and you that readers be, Suppose it was no welcome guest to me. My company and I, it much perplext, And let it come when I send for it next. But leaving jesting, thanks to God I give, 'Twas through his mercy we did scape and live; And though these things with mirth I do express, Yet still I think on God with thankfulness. Thus ceased the storm, and weather gan to smile, And we row'd near the shore of Horsly Isle. Then did illustrious Titan gin to steep His chariot in the Western Ocean deep. We saw the far-spent day, withdraw his light, And made for Harwich, where we lay all night. There did I find an hostess with a tongue As nimble as it had on gimmals hung: 'Twill never tire, though it continual tril'd, And went as yare, as if he had been oil'd. All's one for that, for ought which I perceive, It is a fault which all our mothers have; And is so firmly grafted in the sex, That he's an ass that seems thereat to vex. Apollo's beams began to gild the hills And west southwest the wind the welkin fills, 


\section{EARLY PROSE AND POETICAL WORKS.}

h. It hath not a fellow in England for fishing. i. A book called the Praise of the Red Herring.

i. And a ship Carpenter.
When I left Harwich, and along we row'd Against a smooth calm flood that stifly flow'd, By Bawdsey Haven, and by Orford Nass, And so by Aldborough we at last did pass. By Lowestoff we to Yarmouth made our way, Our third day's travel being Saturday, There did I see a town well fortified, Well govern'd, with all Nature's wants supplied; The situation in a wholesome air, The buildings, for the most part, sumptuous fair, The people courteous, and industrious, and With labour makes the sea enrich the land. Besides, for ought I know, this one thing more, The town can scarcely yield a man a whore. It is renowned for fishing, far and near, And sure in Britain it hath not a pheer. ${ }^{h}$ But noble Nash, thy fame shall live always, Thy witty phamphlet, the red $^{i}$ herring praise, Hath done great Yarmouth much renowned right, And put my artless muse to silence quite. On Sunday we a learned sermon had, Taught to confirm the good, reform the bad; Acquaintance in the town I scarce had any, And sought for none, in fear to find too many. Much kindness to me by mine host was done, A mariner ${ }^{i}$ nam'd William Richardson, Besides mine hostess gave to me at last, A cheese with which at sea we break our fast. The gift was round, and had no end indeed, But yet we made an end of it with speed. My thanks surmounts her bounty, all men sees, My gratitudes in print: but where's the cheese ? So on the Monday, betwixt one and twain, I took leave, and put to sea again.

Down Yarmouth Road we row'd with cutting speed, The wind all quiet, arms must do the deed; Along by Castor, and sea-bordering towns, Whose cliffs and shores abide stern Neptune's fro wns, Sometimes a mile from land, and sometimes two, As depths or sands permitting us to do, 
Till drawing towards night, we did perceive The wind at east, and seas began to heave. The rolling billows all in fury roars And tumbled us, we scarce could use our oars. Thus on a lee-shore darkness began to come, The sea grew high, the winds 'gan hiss and hum; The foaming curled waves the shore did beat, As if the ocean would all Norfolk eat: To keep at sea was dangerous I did think, To go to land I stood in doubt to sink. Thus landing, or not landing, I suppos'd, We were in peril $j$ round about inclos'd; At last to row to shore I thought it best, j. Were we in a puzzle.

'Mongst many evils, thinking that the least. My men all pleased to do as I command, Did turn the boat's head opposite to land, And with the highest wave that I could spy, I bade them to row to shore immediately. When straight we all leap'd over-board in haste, Some to the knees, and some up to the waist, Were suddenly 'twixt owl-light and the dark, We pluck'd the boat beyond high-water mark. And thus half soused, half stewed, with sea and sweat, We land at Cromer Town, half dry, half-wet. But we supposing all was safe and well, In shunning ${ }^{h}$ Scylla, on Charybdis fell. F'or why, some women; and some children"there That saw us land, were all possessed with fear; - And much amaz'd, ran crying up and down, That enemies were come to take the town. Some said that we were pirates, some said thieves, And what the women says, the men believes; With that four constables did quickly call, Your aid! to arms your men of Cromer all! Then straightway forty men with rusty bills, Some arm'd in ale, all of approved skills, Divided into four stout regiments, To guard the town from dangerous events; Brave Captain ${ }^{l}$ Pescod did the van-guard lead, And Captain Clarke the rearward governed,

$k$. We were like flounders alive in a frying-pan that leaped into the fire to save themselves. l. These were the names of the cumbersome Cromorian constables. 


\section{EARLY PROSE AND POETICAL WORKS.}

Whilst Captain Wiseman, and hot Captain Kimble,

Were in main battalia fierce and nimble.

One with his squadron watch'd me all the night, Lest from my lodging I should take my flight;

A second, like a man of simple note,

Did by the sea side all night watch my boat;

The other two, to make their names renowned,

Did guard the town, and bravely walk the round. And thus my boat, myself, and all my men, Were stoutly guarded, and regarded then ; For they were all so full with fear possessed, That without mirth it cannot be expressed. My invention doth curvet, my muse doth caper, My pen doth dance out lines upon the paper, And in word I am as full of mirth, As mighty men are at their first son's birth. Methinks Moriscoes are within my brains, And Heys and Antics run through all my veins. Heigh, to the tune of Trenchmore I could write The valiant men of Cromer's sad affiright. As sheep do fear the wolf, or geese the fox, So all amazed were these senseless blocks ; That had the town been fir'd, it is a doubt, But that the women there had pish'd it out, And from the men reek'd such a fearful scent,

n. People did come thither three or four miles about, to know what the matter was. That people three ${ }^{m}$ miles thence mus'd what it meant, And he the truth that narrowly had sifted, Had found the constables, had need t'have shifted. They did examine me, I answer'd them I was John Taylor and a waterman, And that my honest fellow, Job and I, Were servants to King James, his Majesty, How we to York, upon a mart were bound, And that we landed, fearing to be drown'd. When all this would not satisfy the crew, I freely ope'd my trunk, and bade them view; I shew'd them books, of chronicles and kings, Some prose, some verse, and idle sonnetings, I shew'd them all my letters to the full ; Some to York's archbishop, and some to Hull ; 
But had the twelve apostles sure been there My witnesses, I had been ne'er the ${ }^{n}$ near. And let me use all oaths that I could use, They still were harder of belief than Jews. They wanted faith, and had resolv'd before, Not to believe what e'er we said or swore. They said the world was full of much deceit, And that my letters might be $e^{n}$ counterfeit. Besides, there's one thing bred the more dislike, Because mine host was known a Catholic. These things concurring, people came in clusters, And multitudes within my lodging musters, That I was almost worried unto death, In danger to be stifled with their breath. And had mine host took pence apiece of those, Who came to gaze on me, I do suppose, No Jack an Apes, Baboon, or Crocodile E'er got more money in so small a ${ }^{p}$ while. Besides, the peasants did this one thing more, They call'd and drank four shillings on my score, And like unmanner'd mongrels went their way, Not spending ought, but leaving me to? pay. This was the household business in mean space, Some rascals ran unto my boat apace, And turn'd and tumbled her, like men of Gotham, Quite topsy turvy upward with her bottom, Vowing they would in tatters piece-meal tear They cursed pirates boat, that bred their fear; And I am sure, their madness, to my harm, Tore a board out, much longer than mine arm. And they so bruis'd, and split our wherry, that She leaked, we cast our water with a hat. Now let men judge, upon this truths revealing, If Turks or Moors could use more barb'rous dealing ; Or whether it be fit I should not write Their envy, foolish fear, and mad despite. What may wise men conceive, when they shall note, That five unarmed men, in a wherry boat, Naught to defend, or to offend with stripes, But one old ${ }^{r}$ sword and two tobacco-pipes,

n. I had as good have said nothing.

o. Diligent Officers.

p. The daneing on the ropes, or a Puppetplay, had come short of his takings accounting time for time.

q. This was more than I could willingly afford. $r$. And the sword was rusty with salt water, that it had need of a quarter's warning ere it would come out. 
s. A iorave seent.

And that of constables a murnivall, Men, women, children, all in general, And that they all should be so valiant, wise, To fear we would a market town surprise. In all that's writ I vow I am no liar, I muse the beacons were not set on fire. The dreadful names of Talbot, or of Drake, Ne'er made the foes of England more to quake Than I made Cromer; for their fear and dolor, Each man might smell out by his neighbour's ${ }^{8}$ choler. At last the joyful morning did approach, And Sol began to mount his flaming coach. Then did I think my purgatory done, And 'rose betimes intending to be gone; But holla! stay, 'twas otherways with me, The mass of constables were shrunk to three: Sweet Mr. Pescods double diligence Had horsed himself, to bear intelligence To Justices of Peace within the land, What dangerous business there was now in hand. There was I forc'd to tarry all the while, Till some said he rode four and twenty mile, In seeking men of worship, peace and quorum, Most wisely to declare strange news before um. And whatsoever tales he did recite, I'm sure he caus'd Sir Austin Palgrave, Knight, And Mr. Robert Kemp a Justice there Came before me, to know how matters were. As conference 'twixt them and I did pass, They quickly understood me what I was; And though they knew me not in prose and looks, They had read of me in my verse and books. My businesses account I there did make, And I and all my company did take The lawful oath of our allegiance then, By which we were believ'd for honest men. In duty, and in all humility

I do acknowledge the kind courtesy Of those two gentlemen; for they did see, How much the people were deceiv'd in me. 
They gave me coin, and wine, and sugar too, And did as much as lay in them to do, To find them that my boat had torn and rent, And so to give them worthy punishment. Besides, Sir ${ }^{t}$ Austin Palgrave bade me this, To go but four miles, where his dwelling is, And I and all my company should there Find friendly welcome, mix'd with other cheer. I gave them thanks, and so I'll give them still, And did accept their cheer in their good will. Then 3 a clock at afternoon and past, I was discharged from Cromer at the last. But for men shall not think that enviously Against this town I let my lines to fly; And that I do not lie, or scoff, or fable, For them I will write something charitable. It is an ancient market town that stands Upon a lofty cliff of mouldring sands. The sea against the cliffs doth daily beat, And every tide into the land doth eat; The town is poor, unable by expense, Against the raging sea to make defence. And every day it eateth further in, Still waiting, washing down the sand doth win, That if some course be not ta'en speedily, The town's in danger in the sea to lie.

A goodly church stands on these brittle grounds, Not many fairer in Great Britain's bounds ; And if the sea shall swallow it, as some fear, 'Tis not ten thousand pounds the like could rear. No Christian can behold it but with grief, And with my heart I wish them quick relief. So farewell Cromer, I have spoke for thee, Though thou did'st much unkindly deal with me; And honest mariners, I thank you there, Labouriously you in your arms did bear My boat for me, three furlongs at the least, When as the tide of $\epsilon b b$ was so decreased, You waded, and you launched her quite afloat, And on your backs you bore us to our boat.

t. He would have had us to have staid three or four days with him. 


\section{EARLY PROSE AND POETICAL WORKS.}

u. They longed for employment, and rather than be idle, would be ill occupied. v. The god of rivers, springs, brooks, floods and fountains.
The unkindness that I had before, it come, Because the constables were troublesome; Longed to be busy, would be men of action, Whose labours was their travel's satisfaction. Who all were born when wit was out of town, And therefore got but little of their own. So farewell Pescod, Wiseman, Kimble, ${ }^{u}$ Clarke, Four sons of Ignorance, or much more dark, You made me loose a day of brave calm weather, So once again farewell, fare ill together. Then 'longst the Norfolk coast we rowed outright To Blackney, when we saw the coming night, . The burning eye of day began to wink, And into Thetis lay his beams to shrink; And as he went, stained the departed sky, With red, blue, purple, and vermillion dye, Till all our hemisphere laments his lack, And mourning night puts on a robe of black, Bespangled diversely with golden sparks, Some moveable, some seamen's fixed marks. 'The milky way that blest Astraea went, When as she left this earthly continent, Showed like a crystal causeway to the thrones Of Jove and Saturn, paved with precious stones. Old Oceanus, Neptune, ${ }^{v}$ Inachus, And two and thirty huff-cap'd Aolus, Had all ta'en truce and were in league combined, No billows foaming, or no breath of wind; The solid earth, the air, the ocean deep, Seemed as the whole world had been fast asleep. In such a pleasant even' as this came I To Blackney, with my ship and company. Whereas I found my entertainment good For welcome, drinking, lodging, and for food. The morrow when Latona's sun 'gan rise, And with his light illumines mortal eyes; When cocks did crow, and lambs did bleat and blee, I mounted from my couch and put to sea. Like glass the ocean's face was smooth and calm, The gentle air breath'd like Arabian balm; 
Gusts, storms, and flaws, lay sleeping in their cells, Whilst with much labour we row'd o'er the Wells. This was the greatest ${ }^{2}$ day of work indeed, And it behov'd us much, to make much speed; For why, before that day did quite expire, We past the dangerous Wash to Lincolnshire; And there in three hour's space and little more, We row'd to Boston from the Norfolk shore, Which do report of people that dwell there, Is six and twenty mile, or very near. The way unknown, and we no pilot had, Flats, sands, and shoals, and tides all raging mad, Which sands our passage many times denied, And put us sometimes $y$ three or four miles wide; Besides the flood runs there with such great force, That I imagine it out-runs a horse;

And with a head some four foot high then roars, It on the sudden swells and beats the shores. It tumbled us a ground upon the sands, And all that we could do with wit or hands Could not resist it, but we were in doubt, It would have beaten our boat's bottom out. It hath less mercy than Bear, Wolt, or 'Tiger, And in those countries it is call'd the Higer. We much were unacquainted with those fashions, And much it troubled us with sundry passions. We thought the shore we never should recover, And look'd still when our boat would tumble over; But He that made all with his word of might, Brought us to Boston, where we lodg'd all night. The morrow morning when the sun 'gan peep, I awak'd and rubb'd mine eyes, and shak'd off sleep, And understanding that the river went, From Boston up to Lincoln, and to Trent, To Humber, Ouse, and York, and, taking pain, We need not come in sight of sea again. I lik'd the motion, and made haste away To Lincoln, which was fifty miles that day; Which city in the third king Edward's reign, Was th' only staple, for this kingdom's gain.

20. We rowed about one hundred miles that day.

y. Sands lying crookedly in our way, making us go three or four miles about at low water.

z. It is so called in Mr. Drayton's second part of Polyolbion, his treatise of Humber. 


\section{EARLY PROSE AND POETICAL WORKS.}

a. It is a passage cut through the land eight miles from Lincoln into Trent, but through either the people's poverty or negligence, it is grown up with weeds and mud, so that in the summer it is in many places almost dry. b. I went fifteen miles out of Trent down Humber on purpose to see Hull, when my way was quite contrary.
For leather, lead, and wool, and then was seen Five times ten churches there, but now fifteen. A brave cathedral church there now doth stand, That scarcèly hath a fellow in this land.

'Tis for a godly use, a goodly frame, And bears the blessed Virgin Mary's name. The town is ancient, and by course of fate, Through wars and time defac'd and ruinate; But monarchies and empires, kingdoms, crowns, Have rose or fell, as fortune smiles or frowns, And town and cities have their portions had Of time-tost variations, good and bad. There is a proverb, part of which is this, They say that Lincoln was, and London is. From thence we past a ditch of weeds and mud, Which they do, falsely, there call $a$ Forcedyke flood, For I'll be sworn, no flood I could find there, But dirt and filth, which scarce my boat would bear. 'Tis eight miles long, and there our pains was such, As all our travel did not seem so much; My men did wade and draw the boat like horses, And scarce could tug her on with all our forces. Moil'd, toil'd, mir'd, tir'd, still labr'ing, ever doing, Yet were we nine long hours that eight miles going. At last when as the day was well-nigh spent, We got from Forcedyke's floodless flood to 'Trent. Ev'n as the windows of the day did shut, Down Trent's swift stream to Gainsborough we put. There did we rest until the morning star The joyful doors of dawning did unbar. To Humber's churlish streams our course we fram'd, So nam'd for drowning of a king so nam'd. And there the swift ebb tide ran in such sort, The wind at east, the waves break thick and short; That in some doubts, it me began to strike, For in my life I ne'er had seen the like. My way was up to York, but my intent Was contrary, for from the fall of Trent $I^{b}$ fifteen miles went downwards, east north-west, When as my way was upward, west south-west, 
And as against the wind we madly venture, The waves like pirates board our boat and enter;

But though they came in fury and amain, Like thieves we cast them overboard again. This conflict lasted two hours to the full, Until we gat to Kingston upon Hull. For to that town I had proved a friend, That letters did and commendations send By me unto the worthy Magistrate, The Mayor, and some of's brethren in that state. Besides I had some letters, of like charge, From my good friend, the Master of the Large, Unto some friends of his, that they would there Give me ${ }^{c}$ Hull cheese, and welcome and good cheer. Sunday at Mr. Mayor's much cheer and wine, Where as the Hall did in the parlour dine, At night with one that had been Sheriff I sup'd, Well entertain'd I was, and half well cup'd. On Monday noon, I was invited then To a grave Justicer, an Alderman, And there such cheer as earth and waters yield, Shew'd like a harvest in a plenteous field. Another I must thank for his good will, For he prest ${ }^{d}$ on to bid me welcome still. There is a captain of good life and fame, And, God with us, I oft have call'd his name, He welcom'd me, as I had been his fellow, Lent me his silken colours, black and yellow, Which to our mast made fast, we with a drum Did keep, till we to York in triumph come. Thanks to my loving host and hostess Pease, There at mine inn, each night I took mine ease : And there I got a cantle of Hull cheese One evening late, I thank thee ${ }^{e}$ Maccabees. Kind Roger Parker, many thanks to thee, Thou shew'dst much undeserved love to me, Laid my boat safe, spent time, coin and endeavour, And mad'st money counted copper ever. But as at feasts, the first course being past, Men do reserve their dainties till the last,

c. Hull cheese is much like a loaf out of a brewer's basket. It is composed of two simples, malt and water, in one compound, and is cousin German to the mightiest ale in England.

$d$. The meaning of those marks are only known to the townsmen there.

e. An ingenious man named Machabeus. 


\section{EARLY PROSE AND POETICAL WORKS.}

But most of all, to shut up all together

So my most thanks I ever whil'st I live, Will to the Mayor, and his brethren give,

f. Mr. I. I. I give him thanks that did commend $f$ me thither, Their loves, like Humber, overflow'd the banks, And though I ebb in worth, I'll flow in thanks. Thus leaving off the men, now of the town Some things which I observ'd I'll here set down : And partly to declare its praise and worth, It is the ouly bulwark of the North. All other towns for strength to it may strike, And all the northern parts have not the like. The people from the sea much wealth have won, Each man doth live as he were Neptune's son. 'Th' antiquity thereof a man may read In Reverend Camden's works, and painful Speed : How in King Edward's reign first of that name 'Then called Wyke. Then did they Kingston frame,

g. The river of Hull is twenty miles in length, cut with men's labour, to the infinite commodity of the country.
And then the townsmen cut a ${ }^{g}$ river there,

An ex'lent haven, a defence or pier :

Built with excessive charge, to save it from

Fierce Humber's raging, that each tide doth come.

From time to time, more greatness still it gained, Till lately when the Eighth King Henry reigu'd, He made it greater by his often resort, And many times kept there his Royal Court, He wall'd it well, built battlements, and gates, And, more with honour to augment their states, He built two blockhouses, and castle strong, To guard the town from all invasive wrong. He gave them much munition, swords, shafts, bows, And brazen ordnance, as the world well knows, Which guns he gave them for the town's defence, But were in 88 all borrowed thence, With promise they again should be sent back: But the performance ever hath been slack. Now in this iron age their guns I see, Are metal like the age and iron be, And glad they would be if they could obtain, To change that metal for their own again. 
Four well built gates, with bolts, and locks, and bars, For ornament or strength in peace or wars, Besides to keep their foes the further out They can drown all the land three miles about; 'Tis plentifully serv'd with flesh and fish, As cheap, and reasonable men can wish. And thus by God's grace, and man's industry, Dame Nature, or men's art does it supply.

Some 10 years since firesh water there was scant, But with much cost they have supplied that want; By a most ex'lent water-works that's made, And to the town in pipes it is conveyed, Wrought with most artificial engines, and Perform'd by th' art of the industrious hand Of Mr: ${ }^{h}$ William Maultby, gentleman, So that each man of note there always can But turn a cock within his house, and still They have fiesh-water always at their will, This have they all unto their great content, For which, they each do pay a yearly rent, There is a proverb, and a prayer withal, That we may not to three strange places fall: From Hull, from Halifax, from hell,'tis thus, From all these three, good Lord deliver us. This praying proverb's meaning to set down, Men do not wish deliverance from the town; The town's nam'd Kingston, Hull's the furious river, And from Hull's dangers, I say Lord deliver. At Halifax the law so sharp doth deal, That whoso more than I three pence doth steal, They have a iyn that wondrous quick and well, Sends thieves all headless unto heav'n or hell. From hell each man says, Lord deliver me, Because from hell can no redemption be : Men may escape from Hull and Halifax, But sure in hell there is a heavier tax, Let each one for themselves in this agree, And pray, from Hell good Lord deliver me. The proverb and the prayer expounded plain, . Now to the orders of the town again:

h. He built another fair waterworks at Tork, of freestone, which doth the city exeeeding service. 
i. Mark, for all is true.

I think it merits praise for Government, More than all towns in Britain's continent, As first their charity doth much appear, They for the poor have so ${ }^{i}$ provided there, That if a man should walk from morn till night, He shall not see one beggar; nor a mite Or anything shall be demanded ever, But every one there doth their best endeavour To make the idle work, and to relieve Those that are old and past, or sickness grieve. All poor men's children have a house most fit, Whereas they sew, and spin, and card, and knit ; Where all of them have something still to do, As their capacities will reach unto, So that no idle person, old or young, Within the town doth harbour or belong. It yearly costs five hundred pounds besides, To fence the town, from Hull and Humber tides, For stakes, for bavins, timber, stones, and piles, All which are brought by water many miles, For workmen's labour, and a world of things, Which on the town excessive charges brings. All which with peril, industry and sweat, They from the bowels of the ocean get, They have a Bridewell, and ex'lent skill, To make some people work against their will : And there they have their lodging and their meat, Clean whips, and every thing exceeding neat: And thus with fair or foul means always, they Give idle persons little time to play. Besides, for every sea or marine cause They have a house of trinity, whose laws And orders do confirm, or else reform That which is right, or that which wrongs deform. It is a comely built well ordered place, But that which most of all the house doth grace, Are rooms for widows, who are old and poor, And have been wives to mariners before. They are for house-room, food, or lodging, or For firing, Christianly provided for, 


\section{A MERRY-WHERRY-FERRY VOYAGE. 177}

And as some die, some do their places win, As one goes out, another doth come in.

Should I in all things give the town it's due, Some fools would say I flatter'd, spake untrue;

Or that I partial in my writings were, Because they made me welcome, and good cheer. But for all those that such thoughts of me, I rather wish that them I hang'd may see, Then that they justly could report, that I Did rhyme for victuals, hunger to supply; Or that my muse, or working brains should beat, To flatter, fawn, or lie, for drink or meat. Let trencher-poets scrape for such base vails, I'll take an oar in hand when writing fails ; And 'twixt the boat and pen, I make no doubt, But I shall shift to pick a living out, Without base flattery, or false coined words, To mouldy madams, or unworthy lords;

Or whatsoe'er, degree, or towns, or nations ; I ever did, and still with scorn such fashions. Hear-say, ${ }^{j}$ sometimes upon a lie may light, But what I see and know, I dare to write. j. I write not by Mine eyes did view, before my pen set down, These things that I have written of this town: A new built Custom-house, a fair Town-hall, For solemn-meeting, or a festival:

A mayor, twelve aldermen, one sheriff, recorder, A town-clerk, altogether in one order, And uniformity do govern so, They need not flatter friend, or fear a foe; A sword, a cap of maintenance, a mace Great, and well gilt, to do the town more grace, Are borne before the mayor, and aldermen, And on festivities, or high-days then, Those magistrates their scarlet gowns do wear, And have six sergeants to attend each year. Now let men say what town in England is, That truly can compare itself with this; For situation, strength and government, For charity, for plenty, for content, 


\section{EARLY PROSE AND POETICAL WORKS.}

For state? and one thing more I there was told,

Not one recusant all the town doth hold,

Nor, as they say, there's not a Puritan,

Or any nose-wife fool precisian,

But great and small, with one consent and will,

Obey his Majesty's injunctions still.

They say that once therein two sisters dwelt,

Which inwardly the prick of conscience felt;

They came to London, having wherewithal,

To buy two bibles, all canonical,

Th' apocrypha did put them in some doubt,

And therefore both their books were bound without.

Except those two, I ne'er did hear of any

At Hull, though many places have too many.

But as one scabbed sheep a flock may mar,

So there's one man, whose nose did stand ajar;

Talk'd verily scurvily, and look'd askew,

Because I in a worthy towns-man's pew

Was placed at church, when God knows I ne'er thought,

To sit there, I was by the owner brought,

This squire of low degree displeased than

Said, I at most was but a water-man,

And that they such great kindness setting forth,

Made more o'th flesh than e'er the broth was worth.

Which I confess, but yet I answer make,

'Twas more than I with manners could forsake;

He sure is some high-minded Pharisee,

Or else infected with their heresy,

And must be set down in their catalogues.

They lov'd the highest seats in synagogues,

And so, perhaps, doth he, for ought I know,

He may be mounted, when I sit below;

But let him not a waterman despise,

For from the water he himself did rise,

And winds and water both on him have smil'd

Else, the great merchant he had ne'er been styl'd.

His character I finely will contrive,

He's scornful proud, and talking talkative.

A great ingrosser of strange speech and news,

And one that would sit in the highest pews; 
But bate an ace, he'll hardly win the game, And if I list, I could rake $\mathrm{e}^{k}$ out his name. Thanks, Mr. Mayor, for my bacon gammon, Thanks, Roger Parker, for my small firesh salmon, 'Twas ex'lent good, and more the truth to tell ye, Boil'd with a fine plum-pudding in the belly. The sixth of August, well accompanied

With best of townsmen to the water's side, There did I take my leave, and to my ship I with my drum and colours quickly skip; The one did dub-a-dub and rumble, brave The ensign in the air did play and wave.

I launch'd, supposing all things had been done, Bounce, from the block-house, quoth a roaring gun, And waring hats on both sides with content, I cried adieu, adieu, and thence we went Up Humber's flood that then amain did swell, Winds calm and water quiet as a well.

We row'd to Ouse with all our force and might, To Cawood, where we well were lodg'd all night. The morrow, when as Phobus 'yan to smile, I forwards set to York eight little mile.

But two miles short of York I landed then, To see that reverend ${ }^{l}$ metropolitan;

That watchful shepherd, that with care doth keep Th' infernal wolf from heav'ns supernal sheep. The painful preacher that, most tree alms-giver, That though he live long, is too short a liver. That man, whose age the poor do all lament, All knowing when his pilgrimage is spent, When earth to earth returns as nature's debtor, They far the proverb, seldom comes the better. His doctrine and example speak his due, And what all people says, must needs be true. In duty I most humbly thank his grace, He at his table made me have a place, And meat and drink, and gold he gave me there, Whilst all my crew i'th hall were filled with cheer. So having din'd, from thence we quickly past 'Through Ouse' strong bridge, to York fair city last.

l. At Bishopsthorpe, where the right reverend Father in God, Toby Matthew Archbishop of York, his Grace did make me welcome. k. But I was ever better with forks to scatter, than with rakes to gather, therefore I would not have the townsmen to mistake chalk for cheese, Richard. 


\section{EARLY PROSE AND POETICAL WORKS.}

a. There is some odds between keeping and spending change. b. Here I make a full point, for I received not a pint in exchange.

c. I thought it my duty, seeing we had come a dangerous voyage, to offer our boat to the chief magistraie; for why should not my boat be as good a monument as Tom Coriat's everlasting, over-trampling, land-conquering shoes, thought I?

d. And forgot to say, I thank you good fellows.
Our drowning scap'd, more danger was ensuing, 'Twas 'size time there, and hanging was a-brewing; But had our fault been ne'er so capital, We at the virtner's bar durst answer all. Then to the good Lord Mayor I went, and told What labour and what dangers manifold, My fellow and myself had past at seas, And if it might his noble lordship please, The boat that did from London thither swim With us, in duty we would give to him. His lordship pausing, with a reverend hum, My friend, quoth he, to-morrow morning come, In the mean space I'll of the matter think, And so he bade me to go ne'er and drink. I drank a cup of claret and some beer, And sure, for ought I know, he ${ }^{a}$ keeps good cheer. I gave his lordship in red gilded leather, A well bound book of all my works together, Which he did take. ${ }^{b}$

There in the city were some men of note, That gladly would give money for our boat; But all this while good manners bade us stay, To have my good Lord Mayor's yea or nay. But after long demurring of the matter, ${ }^{c}$ He was well pleas'd to see her on the water, And then my men row'd half an hour or more, Whilst he stood viewing her upon the shore. They bore his lordship's children in her there, And many others, as she well could bear. At which honour was exceeding merry, Saying it was a pretty nimble wherry. But when my men had taken all this pains, Into their eyes they might have put their gains, Unto his shop he $\mathrm{did}^{d}$ perambulate, And there amongst his bars of iron "sate. I ask'd him if he would our boat forego, Or have her, and his lordship answered, no. I took him at his word and said good-bye, And gladly away with my boat went I. I sold the boat, as I suppos'd most meet. 
To honeste Mr. Kayes in Cunny Street.

He entertain'd me well, for which I thanked him, And gratefully amongst mý friends I'll rank him. My kind remembrance here I put in paper, To worthy Mr. Hemsworth there, a draper; Amongst the rest he's one that I most thank, With his good wife, and honest brother Frank. Now for the city; 'tis of state and port, Where emperors and kings have kept their court, 989 , year of foundation,

Was laid before our Saviour's Incarnation, By Ebranc ${ }^{f}$ who a temple there did rear, And plac'd a Flamen ${ }^{g}$ to Diana there;

But when King Lucius here the stepert swayed, The idols level with the ground were laid, Then Eleutherius, Rome high bishop plac'd An archbishop at York, with titles grac'd, When after Christ 627,

Was Edwin ${ }^{h}$ baptized by the grace of heaven, He pluck'd the minster down, that then was wood, And made it stone, a deed both great and good. The city oft hath known the chance of wars, Of cruel foreign, and of home-bred jars. And those that further please thereof to read, May turn the volumes of great Holinshed, 'Tis large, 'tis pleasant and magnificent, The north's most fertile famous ornament. 'Tis rich and populous, ${ }^{i}$ and hath indeed No want of anything to serve their need; Abundance doth that noble city make, Much abler to bestow, than need to take. So farewell York, the tenth of August then Away I came for London with my men. To dinner I to Pomfret ${ }^{j}$ quickly rode, Where good hot venison staid for my abode. I thank thee worshipful George Shillito, He fill'd my men and me, and let us go. There did I well view over twice or thrice, A strong, a fair, and ancient edifice : Re-edifi'd where it was ruined most,

e. A substantial worthy citizen, who hath been Shrieve of York, and now keeps the George in Cunny street.

f. "Ebranc waa the fifth King of Britain after Brute.

g. An ArchFlamen, which was as an idolatrous high priest to Diana.

h. Edward and his whole family were baptized on Easter day the 12th of April 674.

i. Yorkshire the greatest shire in England, and 308 miles about speed.

j. Pomfret Castie. 


\section{EARLY PROSE AND POETICAL WORKS.}

k. Prince

Charles.

l. Sir Pierce of Exton knight.

King Richard

the second

murdered there.
At th' high and hopeful Prince ${ }^{k}$ of Wales his cost. I saw the room where $\operatorname{Exton}^{l}$ and his rout Of traitors, royal Richard's brains beat out; And if that king did strike so many blows, As hacks and hews upon one pillar shows, There are one hundred slashes, he withstood, Before the villains shed his kingly blood. From Pomfret then, unto my noble friend, Sir Robert Swift at Doncaster we wend, An ancient knight, of a most generous spirit, Who made me welcome far beyond my merit. From thence by Newark, I to Stamford past, And so in time to London at the last,

With friends and neighbours, all with loving hearts, Did welcome me with pottles, pints and quarts. Which made my muse more glib, and blithe to tell This story of my voyage. So farewell.

\section{ANं EpILOGUE.}

Thus have I brought to end a work of pain, I wish it may requite me with some gain. For well I wot, the dangers where I ventured, No full bag'd man would ever durst have entered; But having further shores for to discover Hereafter, now my pen doth here give over. 


\section{JACK A L E N T}

HIS

\section{BEGINNING AND ENTERTAINMENT}

WITH

The mad pranks of his gentleman usher SHROVE-TUESDAY that goes before him And his footman Hunger attending. 
TO

\section{FISHMONGERS AND BUTCHERS.}

\section{GREETING.}

Frienduy, frolic, free-hearted, famous, flourishing Fishmongers ; and brave, bold, battering, beef-braining Butchers, to both your Companies in general I wish health and happiness. I acknowledge you to be haberdashers for the belly, and I wish a plentiful increase of good appetites and hungry stomachs, that every one, in their calling may proof valiant of their teeth, whereby you may merrily by the profit you receive by nimble-chopped feeders. I have plainly set down Jack-a-Lent's good deeds and his bad, his friends and his foes, the great need and necessity we have of his coming once a year into this Kingdom, and the great pity that he is no better entertained and observed. And though it be written in a merry style, yet I dare presume that mirth and truth walk together in it. In a word read it if you like, and judge as you list, please yourselves and I am pleased. And let J. S. hold Jack-a-Lent's stirrup whilst he alights, for of all men, I have most reason to prefer him, for a trick he showed me lately. So I rest yours ever, and his as far, as he dares swear for twelve pence.

JOHN TAYLOR. 


\section{JACK A LENT:}

HIS

\section{BEGINNING AND ENTERTAINMENT.}

OF Jack-an-Apes I list not to indite, Nor of Jack Daw my goose's quill shall write; Of Jack of Newbury I will not repeat, Nor Jack of both sides, nor of Skip-Jack neat. To praise the turnspit Jack, my muse is mum, Nor of the entertainment of Jack Drum I'll not rehearse; nor of Jack Dog, Jack Date, Jack Fool, or Jack-a-Dandy, I relate, Nor of black Jacks at gentle buttery bars, Whose liquor oftentimes breeds household wars; Nor Jack of Dover that grand jury Jack, Nor Jack Sause, the wor'st knave amongst the pack; But of the Jack of Jacks, great Jack a Lent, To write his worthy acts is my intent; How he's attended with a mess of Jacks, Whose fame my heartless, weak invention cracks, Jack Herring and Jack Sprat, Jack Straw, Jack Cade, These are the Jacks with which my pen must trade.

To speak of the original of this Jack, or from whence the name of Jack hath derivation, I think it not impertinent to show you; therefore I would have all men understand that Jack is no Christian, nor was ever baptised, but is sprung, like a mushroom, out of the corruption of the name of John; for before Johns were, I did never find mention of any Jacks, except black Jacks. And there was an old courteous epithet attributed to John, as gentle John, but now so many Jacks are made gentles, that most Johns and Jacks make no further account of gentility than glorious titles and gaudy suits. So much for Jack.

Now for the name and beginning of Lent, as near as I can I will describe. The word Lent doth signify, a thing borrowed, for except a thing be borrowed, how is it lent? and being lent, it follows by consequence that it 


\section{EARLY PROSE AND POETICAL WORKS.}

was borrowed; but from whom it was so free of the loan of this Lent, that would be known.

First then you must conceive, that the true etymology, or ancient name of this Lent is Leantide, which being anagrammatized, Landit, for the chief provision that he is furnished withal being fish, and such sea-faring fare, that except he land it, there will be but cold takings in the fish markets; for Jack-a-Lent hath no society, affinity or propinquity with flesh and blood, and by reason of his leanness, as Nymshag, an ancient, Utopian philosopher, declares in his treatise of the antiquity of ginger-bread, lib. 7, page 30000, he should have been a footman to a prince of that empire named Lurguash Haddernot; but Lent showed him the trick of a right footman, and ran away from him faster than an Irish lackey, and from that time to this was never seen in Utopia. Besides, he hath the art of legerdemain beyond all the jugglers in Egypt or Europe, for with a trick that he hath, he is in England, Scotland, France, Ireland, and the most part of the Christian world at one and the self-same time, yet for all this nimbleness, and quick agility, he was never seen to sweat, which is no marvel, because he hath not any fat or pinquidity in his incorporeal corpse. He hath a wife named Fasting, as lean as himself, yet sure I think she is as honest as barren; but it were very dangerous for an epicure or a puritan to have a bastard by her, for there were no other hope, but that the father of the brat, if it should prove male, would tutor it in all disobedience against both Lent and Fasting; for although Lent and abstinence be but forty days endurance, yet to these valiant men of their teeth it seems forty years, for they put the letter " $\mathrm{e}$ " into the word Fast and turn it into Feast. And though a man eat fish till his guts crack, yet if he eat no flesh he fasts, because he eats as fast as he can. For the word fast is to be taken in many senses, as to fast from feeding, and to feed fast, to be bound to fast, and to be bound fast.

The fast from feeding is divers ways performed.

1. Some there are that fast for pure devotion, with a zealous abstinence from any kind of corporal food for a 
space, because they will bring down and curb their unbridled affections, and tame their fleshy desires, that so the exercise of spiritual contemplation may be the more fervent, their repentance more unfeigned, and their prayers more acceptable.

2. Another fast is hypocritical or sophistical, as a holy maid that enjoined herself to abstain four days from any meat whatsoever, and being locked up close in a room, she had nothing but her two books to feed upon, but the books were two painted boxes, made in the form of great bibles with clasps and bosses, the inside not having one word of God in them, nor any fault escaped in the printing, but the one well filled with suckets and sweet meats, and the other with wine, upon which this devout votary did fast with zealous meditation, eating up the contents of one book, and driuking contentedly the other.

Then there is a fast called in spite of your teeth, and that is, Will ye nill ye, when a man's stomach is in folio, and knows not where to have a dinner in decimo sexto. This fast I have often met withal at the court, and at diver's great men's houses, not because there hath wanted meat, but because some have wanted manners, and I have wanted impudence.

But Jack-a-Lent's Fast is otherwise than all these, for I am as willing to fast with him as to feast with Shrovetide; for he hath an army of varions dishes, an host of divers fishes, with salads, sauces, sweatmeats, wine, ale, beer, fruit, roots, raisins, almonds, spices, with which I have often, and care not much to do more often, made as good a shift to fast, and with as good a zeal performed it, as a Brownist will go to plough upon a Christmas day.

Thus having showed the original of this Jack, it follows next, that I declare his yearly entertainment into this Isle of Great Britain, what privileges he hath, to whom he is best welcome, who are glad of his departure, what friends or foes he hath, and where he inhabiteth all the year after his going from hence.

Always before Lent there comes waddling a fat gross bursten-gutted groom, called Shrove-Tuesday, one whose manners shows, that he is better fed than taught; and 


\section{EARLY PROSE AND POETICAL WORKS.}

indeed he is the only monster for feeding amongst all the days of the year, for he devours more flesh in fourteen hours, than this whole kingdom doth, or at the least should do, in six weeks after. Such boiling and broiling, such roasting and toasting, such stewing and brewing, such baking, frying, mincing, cutting, carving, devouring, and gorbellied gormondizing, that a man would think people did take in two months' provisions at once into their paunches, or that they did ballast their bellies with meat for a voyage to Constantinople or to the West Indies.

Moreover, it is a goodly sight to see how the cooks in great men's kitchens, do fry in their master's suet, and sweat in her own grease, that if ever a cook be worth the eating it is when Shrove-Tuesday is in town, for he is so stewed and larded, roasted, basted, and almost overroasted, that a man may eat the rawest bit of him and never take a surfeit. In a word, they are that day extreme choleric, and too hot for any man to meddle with being monarchs of the marrow-bones, marquesses of the mutton, lords high regents of the spit and the kettle, barons of the gridiron, and sole commanders of the fryingpan, and all this hurly-burly, is for no other purpose but to stop the mouth of this land-wheel, Shrove-Tuesday. At whose entrance in the morning all the whole kingdom is in quiet, but by that time the clock strikes eleven, which, by the help of a knavish sexton, is commonly before nine, then there is a bell rung, called the pancake bell, the sound whereof makes thousands of people distracted, and forgetful either of manner or humanity. Then there is a thing called wheaten flour, which the sulphery necromatic cooks do mingle with water, eggs, spice, and other tragical magical enchantments, and then they put it by little and little into a frying-pan of boiling suet, where it makes a confused dismal hissing like the Lernean snakes in the reeds of Acheron, Styx or Phlegethon, until at last by the skill of the cook, it is transformed into the form of a flap-jack, which in our translation is called a pancake, which ominous incantation the ignorant people do devour very greedily, having for 
the most part dined well before: but they have no sooner swallowed that sweet candied bait, but straight their wits forsake them, and they run stark mad, assembling in routs and throngs numberless of ungoverned numbers, with uncivil civil commotions.

Then Tim Tatters, a most valiant villain, with an ensign made of a piece of a baker's mawkin fixed upon a broom staff, he displays his dreadful colours, and calling the ragged regiment together, makes an illiterate oration, stuffed with most plentiful want of discretion; the conclusion whereof is, that somewhat they will do, but what they know not. Until at last comes marching up another troop of tatterdemalions, proclaiming wars against no matter who, so they may be doing. Then these youths armed with cudgels, stones, hammers, rules, trowels, and hand-saws, put play houses to the sack, and bawdy houses to the spoil, in the quarrel breaking a thousand quarrels, of glass I mean, making ambitious brickbats break their necks, tumbling from the tops of lofty chimneys, terribly untiling houses, ripping up the bowels of feather-beds, to the enriching of upholsterers, the profit of plasterers, and dirt daubers, the gain of glaziers, joiners, carpenters, tiler's, and bricklayers. And which is worse, to the contempt of justice: for what avails it for a constable with an army of reverend rusty bill-men to command peace to these beasts, for they with their pockets instead of pistols, well charged with stone-shot, discharge against the image of authority, whole volleys as thick as hail, which robustious repulse puts the better sort to the worser part, making the band of unscoured halberdiers retire faster than ever they came on, and show exceeding discretion in proving tall men of their heels. Thus by the unmannerly manners of Shrove-Tuesday constables are baffled, bawds are banged, punks are pillaged, panders are plagued, and the chief commanders of these valorous villiacoes, for their reward for all this confusion, do in conclusion purchase the inheritance of a jail, to the commodity of jailors, and discommodity to themselves, with a fearful expectation that Tyburn shall stop their throats, and the hangman take possession of 


\section{EARLY PROSE AND POETICAL WORKS.}

their coats, or that some beedle in bloody characters shall imprint their faults on their shoulders. So much for Shrove-Tuesday, Jack-a-Lent's gentleman usher, these have been his humour's in former times, but I have some better hope of reformation in him hereafter, and indeed I wrote this before his coming this year 1617, not knowing how he would behave himself, but tottering betwixt despair and hope, I leave him.

Shrove-Tuesday having played these parts aforesaid, doth exit, and next day Lent begins to enter, who is entertained by a grave, formal, reverend statesman, called civil policy; but you must understand that Lent would very feign take up his lodging here with religion, but religion will not be acquainted with him, and therefore civil policy hath the managing of the business. But it is a wonder to see what munition and artillery the epicures, and cannibal flesh eaters do provide to oppose Lent, and keep him out at the staff's end, as whole barrels of powdered beef blow him up, tubs of pork to pistol and shoot him through with his kindred hunger, famine, and desolation, barricadoes of bacon, as strong and impregnable bulwarks against invasive battery. Which civil policy perceiving, causeth proclamations straight to be published for the establishing of Lent's government, but then to see how the butchers, like silenced schismatics, are dispersed, some riding into the country to buy oxen, kine, calves, sheep and lambs, leaving their wives, men and maids, to make provision of pricks for the whole year in their absence; some again of the inferior sort do scout into stables, privies, cellars. Sir Francis Drake's ship at Deptford, my Lord Mayor's barge, and divers secret and unsuspected places, and there they make private shambles with kill-calf cruelty, and sheepslaughtering murder, to the abuse of Lent, the deceiving of the informers, and the great grief of every zealous fishmonger.

For indeed Lent in his own nature is no blood-sucker, nor cannot endure any blood-shed; and it is his intent, that the bull, the ox, the ram, the goat, the buck, or any other beast, should be free to live in any corporation without molestation. It is Lent's intent, that the innocent 
lamb and Essex calf, should survive to wear the crest of their ancestors ; that the goose, the buzzard, the widgeon, and the woodcock, may walk fearless in any market town, cheek by jole with a headborough, or a tithingman.

The cut-throats butchers, wanting throats to cut, At Lent's approach their bloody shambles shut;

For forty days their tyranny doth cease,

And men and beasts take truce and live in peace.

'The cow, the sow, the ewe may safely feed,

And low, grunt, bleat, and fructify and breed;

Cocks, hens, and capons, turkey, goose, and widgeon,

Hares, conies, pheasant, partridge, plover, pigeon,

All these are from the break-neck poulterer's paws

Secured by Lent, and guarded by the laws;

The goring spits are hanged for fleshly sticking,

And then cook's fingers are not worth the licking.

But to recount the numberless army that Lent doth conduct, the great munition and artillery that he hath to withstand those that gainstand him, his weapons of offence and defence, and variety of hostile accoutrements that his host is armed withal, if I should write all these things, my memory must be boundless, because my work would be endless. First, marches Sir Laurence Ling with his regiment, an ancient sea-faring gentleman. Next follows Colonel Cod, oftentimes bleeding fresh in the battle; then comes Captain Stock-fish, a well-beaten soldier, and one that is often proved to endure much; Sir Salmon Salt, in a pitiful pickle valiantly abides the conflict, and Gilbert Gubbins, all to tatters like a ragged soldier, many times pieces out a broken supper. The majestical king of fishes, heroical, most magnificent herring, armed with white and red, keeps his court in all this hurly-burly, not like a tyrannical tear-throat in open arms, but like wise Diogenes in a barrel, where if any of his regiments either do or take injury, though he want the sword of justice, yet he hath the scales, which I imagine he carries not for nought. The great Lord Treasurer to this mighty prince, old Oliver Cob, is very inward with 


\section{EARLY PROSE AND POETICAL WORKS.}

him, and knows more of his secrets than all his privy council besides; and when his hard-roed master means to shew himself in his red, bloody colours, then in fury he associates himself with two notorious rebels, Jack Straw and Jack Cade, who do encompass him round, and beleager him on each side, guarding his person from the fury of wind and weather.

The wet fishmongers all this while, like so many executioners, unkennel the salt eels from their briny ambuscadoes, and with marshal law hang them up: the stockfish having tried a terrible action of battery is condemned to be drowned, the ling, haberdine, green-fish, and coalfish, are drawn and quartered into poles, backs, and tails, and (like rebels in Ireland) hanged with a withe: nay the king of fishes himself cannot escape, but is tyrannically broiled upon a gridiron. Then comes Jack-Sause with a spoon creeping out of a mustard pot, armed in a pewter saucer, a desperate fellow, and one that dares take Davy Ap Diggon, or Shen Ap Morgan, by the nose, and many times (with the spirit of Tewkesbury) he will make a man weep being most merry, and take the matter in snuff being well pleased.

The whiting, rochet, gournet, and the mop,

The skate and thornback, in the net doth drop:

The pied-coat mackerel, pilchard, sprat and sole,

To serve great Jack-a-Lent amain do troll.

In the rearward comes Captain Crab, Lieutenant Lobster, whose catching claws always puts me in mind of a sergeant, the blushing prawn, the well-armed oyster, the escalop, the welk, the mussle, cockle, and periwinkle, these are hot shots, venereal provocators, fishy in substance, and fleshly in operation. The poor anchovy is pitifully peppered in the fight, whilst the sturgeon is kegged, randed, and joled about the ears, and in conclusion, without dissembling eaten with fennel the emblem of flattery; but the anchovy is oftentimes revenged upon his eaters, for being devoured raw, he broils in their stomachs so hotly, that before the heat be quenched the eaters are drenched in the blood of Bacchus, sack and claret, that though a man be as wise as a constable at his 
entrance, his wit sometimes is so shrunk in the wetting, that he may want the understanding of an ass.

Then there are a crew of near bred freshwater soldiers, our Thamesisians, our comrades of Barking, our eastern and. western river-rovers, these youths are brought and caught by whole shoals, for indeed they are no fighters, but mere white-livered, heartless runaways, like the Turk's asapye (sic), that if the fishermen, like diligent catchpoles, did not watch narrowly to catch them by hook and by crook, by line and leasure, Lent might gape for gudgeons, roach, and dace, were it not for these netmongers, it is no flat lie to say, the flounder might lie flat in his watery cabin, and the eel, whose slippery tail put me in mind of a formal courtier's promise, would wriggle up and down in his muddy habitation, which would be a great discommodity for school boys, through the want of scourges to whip gigs and town tops.

The bream, the lamprey, barbel, but, and pike, Secure might keep the river, pond, and dike; Carps, tench, perch, smelts, would never come to land, But for nets, angles, and the fisher's hand ; And bawling queans that use to sell and buy, Would cry, because they want wherewith to cry.

To speak of the honesty of fishermen, and the account that we ought to make of their calling, it was the faculty of Simon, Andrew, James and John, the blessed apostles, and by a common rule, all fishermen must be men singularly endued, and possessed with the virtue of patience; for the proverb says, "If you swear you shall catch no fish," and I myself hath been an eye-witness, when seven or eight anglers have employed their best art and industry two hours, and in the end they have not been able to share one gudgeon or a bleak amongst them all, the cause hath been, either there was no fish to be caught, or else one impatient fellow of the company had sworn away good luck.

I could run ten kingdoms, or reams of paper out of breath in the praise of this lean Jack and his spawns, Ember weeks, Fridays, and fasting days; but I suppose 


\section{EARLY PROSE AND POETICAL WORKS.}

there are none more sorrowful in the time of his being here than gentlemen and gentlewomen, for through the royal court, the inns of court, the city and country, all the better sort wear mourning black as long as Lent is in town; but so soon as he is gone, then they change colours, and feast, banquet, revel, and make merry, as if the land were freed from some notorious, termagant monster, some murdering plague, or some devouring famine.

The bakers metamorphose their trade from one shape to another, his round, half-penny loaves are transformed into square wigs, which wigs like drunkards are drowned in their ale; the rolls are turned to simnels in the shape of bread-pies; and the light puffed-up four-cornered bun, doth show that the knavery of the baker is universal in Asia, Europe, Africa, and America. For since colliers and scriveners have purchased the possession of the pillory from them, their light bread brings in heavy gains, where if by chance a batch or a basket full being examined by the scales of justice, and the bread committed to Newgate for want of weight, and the baker to the Counter for lack of conscience, yet he knows he shall out again, and with a trick that he hath, in one week he will recover the consumption of his purse again, by his moderate light handling of the medicine of meal, yeast and water.

But now suppose that Palm-Sunday is past, and that you see Lent, and both the fish-streets sing loth to depart, whilst every fishmonger wrings his hands and by the reason of cold takings, beats himself into a heat, whilst, to their great grief, whole herds of oxen, arid flocks of sheep, are driven into every town for no other purpose, but to drive Lent out of the country.

Then pell-mell murder, in a purple hue,

In reeking blood his slaughtering paws imbrue;

The butcher's axe, like great Alcides' bat,

Dings deadly down, ten thousand thousand flat.

Each butcher by himself makes marshal laws,

Cuts throats, and kills, and quarters, hangs, and draws.

It is a thing worthy to be noted, to see how all the dogs in the town do wag their tails for joy, when they 
see such provision to drive away Lent, for a dog, a butcher, and a puritan, are the greatest enemies he hath; but there is one day in the year that dogs in general are most afraid, and that is the Friday after Easter, for they having past six weeks without seeing any flesh, and endured a hard siege by Lent and fish bones, then at Easter they see flesh on the Sunday, Monday, Tuesday, Wednesday, and Thursday, and when the Friday comes, they see great store of fish again, the poor curs, all in a pitiful quandary, stink for woe, for fear that another Lent is come suddenly upon them, thus they continue in that dogged perplexity till the Sunday following, when the appearance of flesh makes them have a feeling that they were more afraid than hurt.

But imagine Lent is gone, but who knows whither he is gone? that would be known; for it cannot be but that so mighty a monarch as he, hath his inroads and his out loops, his standing court of continual residence, as well as his tents, houses, and places of removal for pleasure and progress. For he comes to us by way of annual visitation. 'To the Capuchin friars he comes twice every year, for they keep two Lents because they will be sure to fast double, for when a thing is well done, 'tis an old saying, it is twice done, and by consequence a thing being twice done, must be well done. I know not why they do it, but some say, that it is a work of supererogation, and so I leave them.

But Lent keeps his continual court with the holy convents of the unsanctified fathers, the friars Carthusians, these are they that have made a perpetual divorce between beasts and birds, these are they that have confirmed an everlasting league with Lent, and all the ragged aquarian regiments of the spacious kingdom of Pisces. For when they enter into their order first, they are enjoined never to touch or taste any manner of flesh whatsoever, which they do inviolably perform; for let hunger and thin-gutted famine assault them never so cruelly, so that there were no fish to be had, yet they hold it meritorious to starve and famish, rather than to eat flesh. For indeed.in cases of necessity they have power to 


\section{EARLY PROSE AND POEIICAL WORKS.}

metamorphose flesh into fish, as for example, when any town is besieged and sharply assailed with war without, and famine within, that meat is fallen into such a consumption, that fish is gone, and flesh is scarce, then these venerable fathers, by apostatical power which they have, can take a sirloin of beef, and thrust his knighthood into a tub of water, and command him to come forth transformed into a ling, and so for all kind of flesh else, they can turn a pig to a pike, a goose to a gurnet, a hen to a herring, a sow to a salmon, and an owl to an oyster; and all these are no wonders to them, for they are all as nothing to their exorcising trick of transubstantiation in the sacrament; for it is not possible for anything to be impossible to them that can make their Maker, and conjure their Saviour into a piece of bread, and eat him when they have done. With these enemies of carnality Lent hath domestical perpetuity, these observe his laws more firmly, than they do either the first or second table, and twenty citizens shall break politically, and take up their lodging in Lud's unlucky gate before they will crack the least injunction that is articulated betwixt Lent and them.

Thus having shewed the progress, egress and regress of this Mediterranean, Atlantic, Belgic, Gallobelgicus, this Caspian, Hibernian, British, Celtic, Caledonian, commanding marine countermander, I think it not amiss to declare what good he doth in this kingdom the time of his being: here, and how much more good he would do if he were rightly observed.

As it is a matter of conscience to obey superior and supreme magistrates, so in that respect I hold it a conscience to abstain from flesh-eating in Lent; not that I think it to be unclean to the clean, or that the eating or not eating, is meritorious; for I am persuaded that a man may go to heaven as well with a leg of a capon, as with a red herring. But seeing Lent is ordained to a good intent, for the increase and preservation of calves, lambs, swine and all kind of beasts and birds whatsoever, whereby the breeding and multiplicity of these creatures makes our land the terrestrial paradise of plenty, and so 
is, by the bountiful blessings of the Almighty all-giving giver, able to maintain herself, and relieve many neighbouring realms and regions. Surely they are no good commonwealthsmen, that wilfully will break so tolerable an institution, as to refrain six or seven weeks in a year from flesh, having so much variety and change of fish and other sustenance more than sufficient.

It is most certain, that if Lent were truly kept, and the fish days in every week duly observed, and that every house in this kingdom did spend but the quantity of two - haberdine or green fish in a week, that then this kingdom of Great Britain, both for meat and mariners, would be the mistress of the world, and for wealth and riches superlative to the mines of America.

But the nature of man is so perverse, that like Pandora's box, he will be tooting and prying soonest into that which he is most restrained from, wherein he shows himself to be no changling, but the natural son of Adam, and heir to his frailty and disobedience. For in common reason, for a common good, if there were no statutes, no precepts or commands for the keeping of Lent and fish days, men would of themselves, and by their own instigation, bridle their fleshy appetites with the snaffle of discretion. It is an unmeasurable detriment to this kingdom, the abuse, neglect, and contempt of this so laudable and commodious an institution, and the due observing of it duly would be invaluable, I think past the reach of arithmetic; but I have often noted, that if any superfluous feasting or gormondizing, paunch-cramming assembly do meet, the disordered buisiness is so ordered, that it must be either in Lent, upon a Friday or a fasting day; for the meat doth not relish well, except it be sauced with disobedience and contempt of authority. And though they eat sprats on the Sunday, they care not, so they may be full gorged with flesh on the Friday night,

Then all the zealous puritans will feast

In detestation of the Romish beast.

For mine own part, as I have before written, I hold fish or flesh no maxims, axioms, or grounds of religion, 
but those that wilfully and contemptuously do eat flesh in the Lent, except such whose appetites are repugnant to fish, and whose nature hath not been used to it, except such as are sick, and women with child, for all which there is a lawful toleration; except such, I say, he that feasts with flesh in Lent, I wish be might be constrained to fast with fish all the year after for his contempt.

Wide and large is the way that I might travel in this spacious business, but few words are best, especially if they be spoken to the wise; and if any poor Jack-a-Lent. do happen into the hands of a fool, 'tis but a fool and a Jack, or two fools well met; but here is the odds, a wise man will make much of a Jack for his plain dealing, when a fool will quarrel with him, and falling together by the ears, tear one another's clothes, and then Jack's paper jerkin goes to wrack.

\section{CERTAIN BLANK VERSES WRITTEN \\ of purpose to no purpose, yet so plainly \\ contrived, that a child of two years \\ old may understand them as well \\ as a good scholar of fifty.}

GREAT Jack-a-Lent, clad in a robe of air,

Threw mountains higher than Alcide's beard;

Whilst Pancradge Church, armed with a samphire blade,

Began to reason of the business thus :

You squand'ring: Troglodytes of Amsterdam,

How long shall Cerberus' tapster be?

What though stout Ajax lay with Proserpine,

Shall men leave eating powdered beef for that?

I see no cause but men may pick their teeth,

Though Brutus with a sword did kill himself.

Is Shooter's-hill turned to an oyster pie,

Or may a May-pole be a buttered plaice?

Then let Saint Katherines sail to Bride-well Court,

And chitterlings be worn for statute lace;

For if a humble-bee should kill a whale.

With the butt-end of the Antarctic pole, 
'Tis nothing to the mark at which we aim; For in the commentaries of Tower ditch, A fat stewed bawd hath been a dish of state. More might be said, but then more must be spoke, The weights fell down because the Jack rope broke. And he that of these lines doth make a doubt, Let him sit down and pick the meaning out. 



\section{THE TRUE CAUSE}

OF

\section{THE WATERMEN'S SUIT CON- CERNING PLAYERS}

AND

THE REASONS THAT THEIR PLAYING ON LONDON SIDE IS THEIR EXTREME HINDRANCES

WITH

A relation how far that suit was proceeded in, and theoccasion that it was not effected 

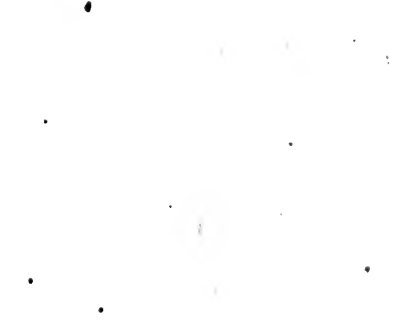


\section{THE CAUSE OF THE WATERMAN'S SUIT CON- CERNING PLAYERS, \&c., \&c.}

THE occasions that hath moved me to write this pamphlet are many and forcible, and the attempt in writing it adventurous and full of danger, for as on the one side I doubt not but with truth to stop the mouths of ignorance and malice that have and do dailyscandalize me, and withal I know I shall purchase a general thanks from all honest men of my company, so I am assured to gain the hatred of some that love me well, and I affect them no worse, only for my plain truth and discharging my conscience; but fall back, fall edge, come what can come, I am resolved, and without fear or flattery, thus I begin.

In the month of January last 1613 , there was a motion made by some of the better sort of the Company of Watermen, that it was necessary for the relief of such a decayed multitude to petition to his Majesty, that the players might not have a playhouse in London or in Middlesex, within four miles of the city on that side of the Thames. Now this request may seem harsh and not well to be digested by the players and their appendices. But the reasons that moved us unto it, being charitably considered, makes the suit not only seem reasonable, but past seeming most necessary to be sued for, and tolerable to be granted.

Our petition being written to purpose aforesaid, I was selected by my Company to deliver it to his Majesty and follow the business, which I did with that care and integrity, that I am assured none can justly tax me with the contrary. I did ride twice to Theobalds, once to Newmarket, and twice to Royston, before I could get a reference upon my petition. 1 had to bear my charge, of my Company first and last, seven pounds two shillings, which horse hire, horse meat, and man's meat brought to a consumption; besides I wrote several petitions to most of the Right Honourable Lords of his Majesty's Privy Council, and I found them all compassionately affected to the necessity of our cause.

First, I did briefly declare part of the services that 
watermen had done in Queen Elizabeth's reign of famous memory, in the voyage to Portugal with the right honourable and never to be forgotten Earl of Essex; then after that, how it pleased God, in that great deliverance in the year 1588 , to make watermen good serviceable instruments with their loss of lives and limbs to defend their prince and country. Moreover, many of them served with Sir Francis Drake, Sir John Hawkins, Sir Martin Frobisher, and others. Besides, in Cadiz action, the Island Voyage, in Ireland, in the Low Countries, and in the narrow seas they have been, as in duty they are bound, at continual command, so that every summer 1,500 or 2,000 of them were employed to the places aforesaid, having but nine shillings four-pence the month a piece for their pay, and yet were they able then to set themselves out like men, with shift of apparel, linen and woollen, and forbear charging of their prince for their pay, sometimes six months, nine months, twelve months, sometimes more, for then there were so few watermen, and the one half of them being at sea, those that staid at home had as much work as they would do.

Afterwards the players began to play on the Bankside and to leave playing in London and Middlesex, for the most part, then there went such great concourse of people by water, that the small number of watermen remaining at home were not able to carry them, by reason of the court, the terms, the players, and other employments, so that we were enforced and encouraged, hoping that this golden stirring world would have lasted ever, to take and entertain men and boys, which boys are grown men, and keepers of houses, many of them being over-charged with families of wife and children,. so that the number of watermen, and those that live and are maintained by them, and by the only labour of the oar and the scull, betwixt the bridge of Windsor and Gravesend, cannot be fewer than forty thousand; the cause of the greater half of which multitude, hath been the players playing on the Bankside, for I have known three companies besides the bear baiting at once there, to wit, the Globe, the Rose, and the Swan. And it is an infallible truth that had they 
never played there it had been better for watermen by the one half of their living, for the company is increased more than half by their means of playing there in former times.

And now it hath pleased God in this peaceful time, that there is no employment at the sea as it hath been accustomed, so that all those great numbers of men remains at home; and the players have all, except the king's men, left their usual residency on the Bankside, and do play in Middlesex far remote from the Thames, so that every day in the week they do draw unto them three or four thousand people that were used to spend their monies by water, to the relief of so many thousands of poor people, which by players former playing on the Bankside are increased, so that oft times a poor man that hath five or six children, doth give good attendance to his labour all day, and at night, perhaps, hath not gotten a groat to relieve himself, his wife and family.

This was the effect and scope of our petition though here I have declared it more at large, to which his Majesty graciously granted me a reference to his commissioners for suits, who then were the right honourable Sir Julius Cæsar, Sir Thomas Parry knights, the right worshipful Sir Francis Bacon, then the king's AttorneyGeneral, Sir Henry Montague, his Majesty's Sergreant-atlaw, Sir Walter Cope, Master George Calvert one of the clerks of his Majesty's Privy Council, and Baron Southerton, one of the Barons of the King's Exchequer, these honourable and worshipful per'sons I did oft solicit by petitions, by friends, and by my own iudustrious importunity, so that in the end when our cause was heard, we found them generally affected to the suit we prosecuted.

His Majesty's players did exhibit a petition against us, in which they said, that our suit was unreasonable, and that we might as justly remove the Exchange, the walks in Pauls, or Moorfields to the Bankside for our profits, as to confine them; but our extremities and cause being judiciously pondered by the honourable and worshipful Commissioners, Sir Francis Bacon very worthily said that so far forth as the public weal was to be regarded before 


\section{EARLY PROSE AND POETICAL WORKS.}

pastimes, or a serviceable decaying multitude before a handful of particular men, or profit before pleasure, so far was our suit to be preferred before theirs. Whereupon the players did appeal to the Lord Chamberlain, which was then the Earl of Somerset, who stood well affected to us, having been moved before in the business by Master Samuel Goldsmith, an especial friend of mine, and a gentleman that myself and all the rest of my poor company in general are generally beholden and deeply engaged unto; for of his own free will, to his cost and charge, we must with thankfulness acknowledge he hath been and is continually our worthy friend. Who seeing the wants of such numbers of us, he hath often neglected his own urgent and profitable affairs, spending his time and coin in any honest occasion that might profit us. Thus much I thought good to insert in the way of thankfulness, because of all vices, ingratitude is the most hateíul.

- The Commissioners did appoint me to come on the next day that they sat again, and that then the players and we should know their determinations concerning our bnsinesses; but before that day came, Sir Walter Cope died, and Sir Julius ('asar being Chief Commissioner was made Master of the Rolls, by which means the commission was dissolved, and we never yet had further hearing. Thus far did I proceed in this thankless suit; and because it was not affected, some of my Company partly through malice or ignorance, or both, have reported that I took bribes of the players to let the suit fall, and that to that purpose I had a supper with them at the Cardinal's Hat on the Bankside, and that if I had dealt well with my Company, and dome as I might have done, then all had been as they would have had it.

These and more the like such pretty aspersions, the out-cast rubbish of my Company hath very liberally, unmannerly and ungratefully bestowed upon me, whereby my credit hath been blemished, the good opinion which many held of me lost, my name abused, and I a common reproach, a scorn, a byeword, and baiting stock to the poisonous teeth of envy and slander. 
But I doubt not but what is before said will satisfy any well disposed or honest mind, and for the rest, if there be any such, as I found them ignorant knaves, so I leave them unthankful villains. And I will regard such vipers and their slander so little, that their malice shall not make me give over to do service to my Company, by any honest lawful means, my trade, under God, is my best friend, and though it be poor, I am sure the calling is honest, therefore I will be an assistant in this suit, or any other that may be available unto it; and howsoever we are slightly esteemed by some giddy-headed corkbrains or mushroom painted puckfists; yet the estate of this kingdom knows, that many of the meanest scullers that rows on the Thames, was, is, or shall be if occasion serve, at command to do their prince and country more service than any of the players shall be joined unto.

I must confess that there are many rude uncivil fellows in our Company, and I would some doctor would purge the Thames of them. The reason whereof is, that all men being vicious, by consequence most vice must be in the greatest companies, but watermen are the greatest company, therefore most abuses must reign amongst watermen; yet, not to excuse them in any degree, let a man but consider other trades and faculties of higher account, and I am sure they will come short in honesty, perhaps not of watermen, but of the homest vocation of a waterman.

For if he use his labour no otherwise than he ought, which is to carry the King's liege people carefully, and to land them safely, to take his due thankfully without murmuring or doing injury, then I say, that that waterman may feed upon the labours of his hands with a better conscience, and sleep with a quieter spirit than many of our fur-gowned money-mongers that are accounted good common wealths men; but if a railing knave do chance to abuse his fare, either in words or deeds, as indeed we have too many such, what reason is it, that for the wrong that one, two, or more doth commit, that all the rest of the whole company shall be scandalized for it. If a mercer, a grocer, a goldsmith, or any other of the best 
trades, be a traitor, a thief, or a debauched drunkard, it were impudent ignorance for the vices of a few, that all the rest of the function should be reproached. I will make no odious comparisons, but I am persuaded that there are as many honest men of our company as of any other, such as do make a conscience of what they do; such as will not wrong others though it might be gainful to themselves; such who are both religious and charitable, and whose greatest care is to live in God's fear, that they may die in his favour; and for those that are unruly, ignorant, and brutish, there is no company hath sharper laws, or more severely executed, as the counters can testify once a week. Little ease can witness often. The whip, and the whipper, like a roaring devil doth many times affirm the naked truth, and banishment from the river of Thames for ever, now and then cuts off a bad member. Besides, fines and forfeitures are laid upon the heads of petty offenders, that few or none escapes unpunished if their faults be known. If the gout be in a man's toe, all the body is grieved; if a finger ache, the rest of the members hath a share in the pain ; but if many of the joints and members be putrified, then the heart cannot choose but be crazed with care, if not wounded; so is it with our company, that the abuses and vices of the worst inferior members as graceless, godless, reprobates, are sometimes like a plague, infectious to their betters, and a daily heart-grief to all honest men, who are scandalized by their damnable demeanors. But all they do or can do, is nothing to the defaming of the company, for it were very absurd because one in his drink hath killed a man, to impute the fault to the wine or the drink that he drank, when the blame lies in the drunkard that abused God's good creatures in taking too much; so a waterman's trade is honest, necessary, and not to be wanted, howsoever it is abused by misgoverned uncivil companions. If a waterman would be false in his trade, I muse what falsehood he could use, he hath no false weights or measures to curtail a man's passage, but he will land a man for his money, and not bate him an inch of the place he is appointed. His shop is not dark like a woollen draper's 


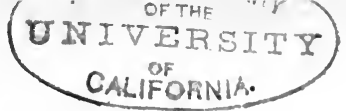

THE IVATERMEN'S SUIT.

on purpose, because the buyer shall not see the coarseness of the cloth, or the fallseness of the colour; no, his work and ware is seen and known, and he utters it with the sweat of his brows, the worst fault is, that like a lawyer he will take more than his fee, if any body will give it him, very thankfully, his bare fare he will take willingly, upon necessity, but less than his fare, or many times nothing, methinks goes against stomach.

I have seen a usurer, who hath been fit only for the grave these seven years being more than half rotten with the gout, the congh, and the mur, who hath lost his conscience to get money, and perhaps win dammation, who is not able to go by land, and yet will not pay his fare by water, but like the picture of misery, will either beg his passage of some serving man, or bargain with a waterman to give him twopence for sixpenny worth of labour; such I have seen, and such there are too many, who if they were once buried, the wheel of time would turn, and what they got unjustly by extortion, oppression, and grinding the finces of the poor, what they have uncharitably pinched in keeping back the labourer's hire, their sons or heirs perhaps will consume in law who shall possess most of that ill-gotten groods, or else drink it, dice it, drab it, revel and ruffle it, till all is gone; and as their fathers before them made others to rot in prison, so their prodigal sons are holed in some loathsome jail, being lousy, lodging on the boards, and live upon the box and the alms-basket.

Moreover, too many there are that pass the bounds of liberality, and spend most prodigally on a whore, on the devil of India, tobacco, on the superfunns quarts and pints of the blood of Bacchus, sack and claret, Spanish and French, on unlawful games, and in a word, on a thousand vanities, they will carelessly and beyond expectation cast away their cash. But upon a waterman that hath rowed till his heart ache, and sweats till he hath not a diy thread about him, the gentleman's bounty is asleep, and he will pay him by the statute, or if he give him two pence more, he hath done a huge work beyond the merit of Sutton's Hospital. 
I myself hath often met with a roaring boy, or one of the cursed crew, that bath had nothing about him but a satin outside to cover his knavery, and that none of his own neither, witness bis mercer and his tailor; yet this gallant must be shipped in a pair of oars at least, but his gay slop hath no sooner kissed the cushions, but with a volley of new coined oaths, newly brought from hell to the Bermudas by the ghost of a knight of the post, he hath never left roaring, row, row, row, a pox on you, row, as if his punk should stay too long for his pestiferous person, and when his scurviness is landed where he pleases, he hath told me I must wait on him, and he will return to me presently, and I shall carry him back again, and be paid altogether. Then have I attended five or six hours, like John-a-Noakes, for nothing, for my cheating: shark hath neither money nor honesty, hath never come at me, but took some other pair of Stairs, and in the same fashion cozened another waterman for his boat-hire.

We must, and do with thankfulness confess that the nobility, gentry, and all others of the better sort of this kingdom, have honest, worthy and charitable considerations of our want of means, and multitude of men; for they do know that house-rent and victuals are at four times the rate which it was at when the statute was made in Queen Mary's reign for our fares, and as the price of all things is raised, except poor men's labours, so do they in conscience very liberally raise our fares accordingly.

And as before I have written, our trade is so useful and necessary, both for the King's service and the commons commodity, that it is not to be, or cannot be wanted, and by how much the more a waterman is near to his Majesty, to the Queen's Majesty, to the Princess Highness, to the nobility, the gentry, and the best of the commonalty of this kingdom, and sometimes of foreign nations, so much the more ought watermen to behave themselves honestly and soberly in their calling. There are many better trades and qualities, that scarce the best of their companies in all their life time do come so often and so near the presence of majesty and nobility as we do. I write 
not to disparage any, nor with boasting to puff up ourselves, none comes nearer, except the barber, and long and often may he come, or the physician and chirurgeon, which God grant they may be ever needless; but a waterman many times hath his sovertign by the hand, to stay him in and out the barge, where there is not above an inch betwixt life and death, the barge being then the royal court, and being but a door betwixt the king and them, they are at that time gentlemen of the privy chamber, or yeomen of the guard at least.

And thus much I am bold to insert for myself, and many more of my company that I know, that we never exacted money wrongfully, or contended with any of the king's liege people for more than they themselves would give with any reason, or gave anyone abusive or unreverend speeches if they would not go with us; for we know that men are free to buy their cloth at what drapers they please, or their stuffs at which mercers they will; what tailor they list make their garments, and what cook they like may dress their meat, and so forth, of all functions every man is free to make his choice. And so amongst watermen, men may take whom they please, because they are bound to none. He that goes with me shall have my labour, and I am in hope to have his money: he that will not go with me goes with another, and I have the more ease the while; he doth me no wrong: in not going with me, and I will do him no injury for going from me. 'This is my resolution, and a number more of my company, and those that are otherwise minded, I wish with all my heart that God will be pleased to amend them, or else that the hangman may have authority to end them.

But to return to the purpose, from which I have too long digressed, the players are men that I generally love and wish well unto, and to their quality, and I do not know any of them but are my friends and wish as much to me; and howsoever the matter falls out, whether they play or not play, I thank God I am able to live as well as another, either with them or without them. But my love is such unto them that whereas they do play but once 


\section{EARLY PROSE AND POETICAL WORKS.}

a day, I could be content they should play twice or thrice a day, so it were not in such places as doth undo so many thousands of poor people; for as it is, it were much better for us that they played nowhere. And seeing so trivial a cause as this would be scarce incommodious to any, and more commodious to us than the four terms in the year, seeing our necessities so great and our relief harmless to any, seeing the use of us expedient, if occasions serve abroad or at home, and our unableness to set ourselves to sea, by reason of our want; our hope is that we shall be as much reckoned of as horses, for horses have meat, drink, and lodging, though they be but seldom ridden, and many of them have a warm footcloth, when thousands of serviceable men are like to famish and starve through want and nakedness.

As concerning our endeavours to remove the shelves and sands in the Thames, which are a great annoyance to the river, and hurtful to the city, as his Majesty hath commanded, and the Right Honorable the Lord Mayor and the rest of his worshipful brethren shall direct, we shall with all willingness do our duties we doubt not both to the King's Majesty's contentment, the good of the city, and the good report of ourselves.

Thus, because the truth shows best being naked, I have plainly set down how far I proceeded in my suit; how it was broken off; what thanks I have for my pains; the necessity of the cause that made me go about it; the abuses I had because it took no effect, which is the chief cause why I wrote this pamphlet to justify myself. All these things I hope the judicious understander will judge accordingly, always esteeming me a loyal lover of my country and my company. 
A NEW DISCOVERY

B Y S E A

WITH A WHERRY

FROM LONDON TO SALISBURY 
To the Nobility, Gentry, and Communalty, who are. Inhabitants or Well-willers to the Welfare of the City of Salisbury, and County of Wiltshire.

\section{Right HoNourable,}

WoRshipful, and loving countrymen, I have named my book and voyage, The Worst or the Best, which I ever undertook and finished, and it lies in your pleasures to make it which you please. I am sure for toil, travail, and danger, as yet I never had a worse or a more difficult passage, which the ensuing discourse will testify; yet, all those perils past, 1 shall account as pleasures if my infallible reasons may move or persuade you to clear your river, and make it navigable from the sea to your city. I have in part touched what the profit and commodities of it will be unto you, and have briefly showed the inconveniences which you have through the want of it. I have also declared that the main intent or scope of my coming unto you with a wherry, was to see what lets or impediments were the hindrances unto so good and beneficial a work. All which I have, according to my simple survey and weak capacity, set down, which with the merriness of my most hazardous sea-progress, I humbly dedicate to your noble, worshipful, and worthy acceptances, ever acknowledging myself and my labour in your services to be commanded in all duty.

JOHN TAYLOR. 


\section{A DISCOVERY BY SEA FROM LONDON TO SALISBURY.}

As our accounts in almanacks agree,

The year call'd sixteen hundred twenty-three, That July's twenty-eight, two hours past dinner, We with our wherry and five men within her, Along the crystal Thames did cut and curry, Betwixt the counties Middlesex and Surrey;

Whilst thousands gaz'd, we passed the bridge with wonder,

Where fools and wise men go above and under.

We thus our voyage bravely did begin

Down by St. Katherines, where the priest fell in, By Wapping, where as hang'd drowned Pirates die, Or else such ${ }^{a}$ rats I think as would eat pie, And passing further, I at first observ'd That ${ }^{b}$ Cuckolds-Haven was but badly serv'd, For there old Time had such confusion wrought That of that ancient place remained nought. No monumental memorable horn,

Or tree, or post, which hath those trophies borne, Was left, whereby posterity may know Where their forefathers crests did grow or show. Which put into a maze my musing Muse, Both at the world's neglect and time's abuse, That that stout pillar to oblivion's pit Shall fall, whereon plus ultra might be writ, That such a mark of reverend note should lie Forgot and hid in black obscurity, Especially when men of every sort Of countries, cities, warlike camps or court, Unto that tree are plaintiffs or defendants, Whose ${ }^{c}$ loves or fears are fellows or attendants ; Of all estates this haven hath some partakers By lot, some cuckolds and some cuckold-makers. a. Any rat that eats pie is a pirat.

b. When I passed down the river there was not any post or horn there, but since is most worthily repaired. And can they all so much forgetful be Unto that ancient and renowned tree

c. All estates or degrees do either love or fear the haven. 


\section{EARLY PROSE AND POETICAL WORKS.}

That hath so many ages stood erected, And by such store of patrons been protected, And now ingloriously to lie unseen,

As if it were not, or had never been?

Is lechery wax'd scarce, is bawdry scant, Is there of whores or cuckolds any want? Are whore-masters decay'd, are ail bawds dead? Are panders, pimps, and apple-squires all fled? No, surely, for the surgeons can declare That Venus' wars more hot than Mars' are; Why then for shame this worthy port maintain, Let's have our tree and horns set up again, That passengers may show obedience to it, In putting off their hats, and bomage do it. Let not the Cornucopiaes of our land Unsightly and unseen neglected stand; $\mathrm{I}$ know it were in vain for me to call That you should raise some famous hospital, Some free-school, or some almshouse for the poor, That might increase good deeds, and open heav'n's door.

'Tis no taxation great, or no collection Which I do speak of for this great erection; For if it were, men's goodnesses, I know, Would prove exceeding barren, dull, and slow. A post and horns will build it firm and stable, Which charge to bear there's many a beggar able; The place is ancient, of respect most famous, The want of due regard to it doth shame us, For Cuckold's-Haven my request is still, And so I leave the reader to his will. But holla Muse, no longer be offended, 'Tis worthily repair'd and bravely mended, For which great meritorious work my pen Shall give the glory unto Greenwich men. It was their only cost, they were the actors Without the help of other benefactors, For which my pen their praises here adorns, As they have beautifi'd the hav'n with horns. From thence to Deptford we amain were driven, 
Whereas an anchor unto me was given.

With parting pints and quarts for our farewell,

We took our leaves, and so to Greenwich fell.

There shaking hands, adieus, and drinkings store,

We took our ship again, and left the shore.

Then down to Erith, 'gainst the tide we went,

Next London, greatest mayor town in Kent

Or Christendom, and I approve it can,

That there the Mayor was a waterman,

Who governs, rules, and reigns sufficiently,

And was the image of authority.

With him we had cheap reck'nings and good cheer,

And nothing but his friendship we thought dear.

But thence we rous'd curselves and cast off sleep,
Before the daylight did begin to peep,

The tide by Gravesend swittly did ns bring,

Before the mounting lark began to sing ;

And ere we came to Lee, with speedy pace

The sun 'gan rise with most suspicious face,

Of foul, foreboding weather, purple, red,

His radiant tincture, east, north-east o'erspread;

And as our oars thus down the river pull'd, Oft with a fowling-piece the gulls we gull'd, For why, the master gunner of our ship

Let no occasion or advantage slip,

But charg'd and discharged, shot, and shot again,

And scarce in twenty times shot once in vain;

d. His name Bray, a waterman of Lambeth, and a good Foul was the weather, yet this much I'll say, If't had been fair, fowl was our food that day. Thus down along'st the spacious coast of Kent By Grane and Sheppys Islands down we went; We passed the Nore-head, and the sandy shore, Until we came to the east end of the Nore; At last by Ramsgate's pier we stifly rowed, The wind and tide against us blow'd and flowed, Till near unto the haven where Sandwich stands. We were enclosed with most dangerous sands; There were we sous'd and slabber'd, wash'd and dash'd, $\begin{gathered}e \text {. We we were five } \\ \text { us were twroid, }\end{gathered}$ And gravel'd, that it made us ${ }^{e}$ half' abash'd; We look'd and pry'd, and stared round about, 


\section{EARLY PROSE AND POETICAL WORKS.}

From our apparent perils to get out;

For with a staff, as we the depth did sound, Four miles from land, we almost were on ground.

At last, unlook'd for, on our larboard side A thing turmoiling in the sea we spyed, Like to a Merman; wading as he did All in the sea his nether parts were hid, Whose brawny limbs, and rough neglected beard, And grim aspect, made half of us afear'd ; And as he unto us his course did make, I courage took, and thus to him I spake: Man, monster, fiend or fish, whate'er thou be That travelest here in Neptune's monarchy, I charge thee by his dreadful three-tin'd mace Thou hurt not me or mine, in any case ; And if thou be'st produced of mortal kind, Shew us some course how we the way may find To deeper water, from these sands so shallow, In which thou seest our ship thus wash and wallow. With that he, shrugging up his shoulders strong, Spake like a Christian in the Kentish tongue. Quoth he, kind sir, I am a fisherman, Who many years my living thus have wan By wading in these sandy troublous waters For shrimps, whelks, cockles, and such useful matters, And I will lead you, with a course I'll keep, From out these dangerous shallows to the deep. Then, by the nose, along he led our boat, Till, past the flats, our bark did bravely float. Our sea-horse, that had drawn us thus at large, I gave two groats unto, and did discharge.

Then in an hour and half, or little more, We through the Downs at Deal went safe on shore. 'There did our hostess dress the fowl we kill'd, With which our hungry stomachs well we fill'd, The morrow being. Wednesday, break of day, We towards Dover took our weary way. 'The churlish winds awak'd the sea's high fury, Which made us glad to land there, I assure ye. Blind Fortune did so happily contrive, 
That we as sound as bells did safe arrive

At Dover, where a man did ready stand, To give me entertainment by the hand;

A man of metal, mark and note, long since He graced was to lodge a gracious prince, And now his speeches sum, and scope and pith Is Jack and Tom, each one his cousin Smith, That if with pleasant talk you please to war'm ye, $\mathrm{He}$ is an host much better than an army; A goodly man, well fed and corpulent, Fill'd like a bag-pudding with good content; A right good fellow, free of cap and leg, Of compliment, as full as any egg: To speak to him, I know it is of folly, $\mathrm{He}$ is a mortal foe to melancholy ;

Mirth in his life and trade, and I think very, That he was got when all the world was merry; Health upon health, he doubled and redoubled, Till his and mine, all our brains were troubled. Unto our absent betters there we drank, Whom we are bound to love, they not to thank. By us mine host could no great profit reap, Our meat and lodging was so good and cheap, That to his praise thus much I'll truly tell, He us'd us kindly every way and well. And though my lines before are merry writ, Where'er I meet him, I'll acknowledge it. To see the Castle there I did desire, And up the hill I softly did aspire,

Whereas it stands, impregnable in strength, Large in circumference, height, breadth, and length, Built on a fertile plat of ground, that they Have yearly growing twenty loads of hay, Great ordnance store, pasture for kine and horses, Rampires and walls, t'withstand invasive forces, That it be well with truth and courage man'd, Munition, victual'd, then it can withstand The powers of twenty Tamberlanes, the Great, Till in the end with shame they would retreat. 'Tis governed by a grave and prudent ${ }^{f}$ Lord,

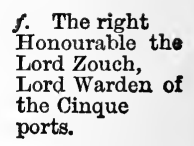

f. The right

Lord Zouch, the Cinque ports. 
Whose justice doth to each their right afford,

Whose worth, within the castle and without, The five ports, and the country all about, The people with much love, do still recite, Because he makes the wrongers render right. The kindness I received there was such, That my remembrance cannot be too much. I saw a gun thrice eight foot long of brass, And in a wheel I saw a comely ass Dance like a dog, that's turning of a spit, And draw as it were from the infernal pit, Whose deep abyss is perpendicular, One hundred fathom, or well near as far, So crystalline, so clear, and cool a water, That will in summer make a man's teeth chatter. And when to see it up, I there had stood, I drank thereof, and found it sweet and good. So farewell Castle, Dover, Dover pier, Farewell, host Bradshaw, thanks for my good cheer. My bonny bark to sea was bound again ; On Thursday morn, we launch'd into the main, By Folkestone and by Sandgate's ancient castle, Against the rugged waves, we tug and wrestle By Hyde, by Romney, and by Romney Marsh, The tide against us, and the wind blew harsh', 'Twixt Æolus and Neptune was such strife, That I ne'er felt worse weather in my life. Toss'd and retoss'd, retoss'd and toss'd again ; With rumbling, tumbling, on the rolling main, The boist'rous breaking billows curled locks Impetuously did beat against the rocks. The wind much like a horse whose wind is broke, Blew thick and short, that we were like to choke, As it outrageously the billows shaves, The gusts, like dust; blown from the briny waves, And thus the winds and seas robustious gods Fell by the ears stark mad at furious odds. Our slender ship, turmoiled 'twixt shores and seas, Aloft or low, as storms and flaws did please; Sometimes upon a foaming mountain's top, 
Whose height did seem the heav'ns to underprop,

When straight to such profundity she fell,

As if she div'd into the deepest hell.

The clouds like ripe apostumes burst and shower'd,

Their mattery watery substance headlong pour'd;

Yet though all things were mutable and fickle,

They all agreed to souse us in a pickle,

Of waters tresh and salt, from seas and sky,

Which with our sweat joined in triplicity,

That looking each on other, there we saw,

We neither were half stew'd, nor yet half raw,

But neither hot or cold, good flesh or fishes

For cannibals, we had been ex'lent dishes.

Bright Phobus hid his golden head with fear,

Not daring to behold the dangers there.

Whilst in that strait or exigent we stand,

We see and wish to land, yet durst not land.

Like rolling hills the billows beat and roar

Against the melancholy beachy shore,

That if we landed, neither strength or wit

Could save our boat from being sunk or split.

To keep the sea, stern puffing Aolus breath

Did threaten still to blow us all to death;

The waves amain, unbid, oft boarded us,

Whilst we almost three hours beleagur'd thus,

On every side with danger and distress,

Resolv'd to run on shore at Dungeness.

There stand some thirteen cottages together,

To shelter fishermen from wind and weather,

And there some people were, as I suppos'd,

Although the doors and windows all were clos'd.

I near the land into the sea soon leapt

To see what people those same houses kept.

I knock'd and call'd at each, from house to house,

But found no form of mankind, man or ${ }^{g}$ mouse.

This news all sad, and comfortless, and cold,

Unto my company I straightways told,

g. No dwelling

within near

three miles of

those cottages.

Assuring them the best way I did think,

Was to haul up the boat, although she sink.

Resolved thus, we all together please 


\section{EARLY PROSE AND POETICAL IVORKS.}

h. The town's name is Lydd, two miles from Romney in

Kent. i. Our beds were cables and ropes, every feather at least 20 fathom long.
To put her head to shore, her stern to seas; They leaping overboard amidst the billows, We pluck'd her up unsunk, like stout tall fellows. Thus being wet, from top to toe we stripp'd Except our shirts, and up and down we skipp'd, Till wind and sun our wants did well supply, And made our outsides and our insides dry. Two miles from thence a ragged ${ }^{h}$ town there stood, To which I went to buy some drink and food; Where kindly over-reckon'd, well misus'd Was, and with much courtesy abus'd. Mine hostess did account it for no trouble, For single fare to make my payments double; Yet did her mind and mine agree together, That I, once gone, would never more come thither. The cabins where our boat lay safe and well, Belong'd to men which in this town did dwell; And one of them, I thank him, lent us then The key to ope his hospitable den, A brazen kettle, and a pewter dish, To serve our needs and dress our flesh and fish. Then firom the butcher's we bought lamb and sheep, Beer from the alehouse, and broom to sweep Our cottage, that for want of use was musty, And most extremely rusty-fusty-dusty. There two days' space we roast, and boil, and broil, And tril, and moil, and keep a noble coil, For only we kept open house alone, And he that wanted beef might have a stone. Or grandame earth with beds did all befriend us, And bountifully all our lengths did lend us, That laughing, or else lying ${ }^{i}$ down did make Our backs and sides sore, and our ribs to ache. On Saturday the winds did seem to cease, And brawling seas began to hold their peace, When we, like tenants beggarly and poor, Decreed to leave the key beneath the door, But that the landlord did that shift prevent, Who came in pudding time and took his rent, Aud as the sun was from the ocean peeping, 
We launch'd to sea again, and left house-keeping.

When presently we saw the drizzling skies

'Gan pout and lower, aud winds and seas 'gan rise,

Who each on other played their parts so wild,

As if they meant not to be reconciled,

The whilst we leap upon those liquid hills,

Where porpoises did show their fins and gills,

Whilst we like various fortune tennis ball,

At every stroke were in the hazard all.

And thus by Rye and ${ }^{j}$ Winchelsea we pass'd,

By Fairlight and those rocky cliffs at last.

Some two miles short of Hastings, we perceiv'd

The lee shore dangerous and the billows heav'd,

Which made us land to 'scape the sea's distress

Within a harbour almost harbourless.

We give God thanks, amongst the rocks we hit,

Yet were we neither wash'd or sunk or split.

Within a cottage nigh there dwells a weaver,

Who entertained us, as the like was never,

No meat, no drink, no lodging but the floor,

No stool to sit, no lock unto the door,

No straw to make us litter in the night,

Nor any candlestick to hold the light,"

To which the owner bid us welcome still,

Good entertainment, though our cheer was ill.

The morrow, when the sun with flushed face

In his diumal course began to trace,

The wind exceeding stiff and strong and tough,

The seas outrageous and extremely rough,

Our boat laid safe upon the beachy sand,

Whilst we to Hastings went or walk'd by land.

Much to that town my thankfulness is bound,

Such undeserved kindness there I found.

Three nights we lay there, and three days we spent,

Most fireely welcom'd, and much merriment.

Kind Mr. ${ }^{*}$ Mayor, his love above the rest;

Mle and my crew he did both feed and feast,

He sent us gold, and came himself to us ;

My tlianks are these, because his love was thus.

Mine host and hostess Clayton thus I thank,

j. I walked to

Winchelsea,

where I thank my cousin, Mr. Collins, the

Mayor there, he made me kindly welcome. k. The Mayor's name was Mr. Richard Boyse, a gentleman whose landable life and honest government is much beloved and approved. 


\section{EARLY PROSE AND POETICAL WORKS.}

And all good fellows there I found so frank, 'That what they had, or what could there be got, They neither thought too heavy or too hot. The winds and seas continued still their course, Inveterate seem'd their ragé, untam'd their force, Yet were we loath to linger and delay; But once again to venture and away. Thus desperately resolv'd, 'twixt hope and doubt, Half sank with launching, madly we went.out, At twelve a clock at noon, and by sunset To Meeching or Newhaven we did get. There almost sunk, to save our boat at last, Ourselves into the shallow seas we cast; And pluck'd her into safety to remain Till Friday that we put to sea again. Then 'mongst our old acquaintance, storms and flaws, At every stroke near death's devouring jaws; The weary day we passed through many fears, And land at last quite sunk o'er head and ears. All dropping dry, like five poor rats half drown'd From succour far, we ha'led the boat on ground, Cast out our water, whilst we bravely drop'd, And up and down to dry ourselves we hop'd. Thus we our weary pilgrimage did wear, Expecting for the weather calm and clear; But storms, flaws, winds, seas, took no minutes rest, Continual fiercely blowing west southwest, A town call'd Goring, stood near two miles wide, To which we went, and had our wants supplied. There we reliev'd ourselves with good compassion, With meat and lodging of the homely fashion, To bed went in hope of rest and ease, But all beleaguer'd with an host of fleas; Who in their fury nip'd and skip'd so hotly, That all our skins were almost turn'd to motley. The bloody fight endur'd at least six hours, When we, opprest with their increasing pow'rs, Were glad to yield the honour of the day Unto our foes, and rise and run away. The night before, a constable there came, 
Who ask'd my trade, my dwielling, and my name:

My business and a troop of questions more, And wherefore we did land upon that shore? To whom I fram'd my answers true and fit, According to his plenteous want of wit; But were my words all true, or if I ly'd, With neither I could get him satisfi'd.

He ask'd if we were pirates? we said no, As if we had we would have told him so. He said that lords sometimes would enterprise, T'escape and leave the kingdom in disguise; But I assur'd him on my honest word, That I was no disguised knight or lord. He told me then that I must go six miles T'a justice there, Sir John, or else Sir Giles; I told him I was loth to go so far, And he told me he would my journey bar. Thus what with fleas, and with the several prates Of th' officer and his associates, We arose to go, but Fortune bade us stay, The constable had stolen our oars away, And borne them thence a quarter of a mile, Quite through a lane, beyond a gate and stile, And hid them there to hinder my depart, For which I wish'd him hang'd with all my heart. A ploughman for us found our oars again, Within a field well fill'd with barley grain. Then madly, gladly out to sea we thrust, 'Gainst winds and storms and many a churlish gust. By Kingston Chapel, and by Rustington, By Littlehampton, and by Middleton, To Bognor's fearful rocks, which hidden lie Two miles into the sea, some wet, some dry; There we suppos'd our danger most of all, If we on those remorseless rocks should fall. But by the Almighty's mercy and His might, We row'd to Selsey, where we stay'd all night; There our necessity could have no law, For want of beds, we made good use of straw, 'Till Sol, that old continual traveller, 


\section{EARLY PROSE AND POETICAL WORKS.}

From Thetis' lap 'gan mount his flaming car. The weather kept it's course, and blow'd and rag'd, Without appearance it would e'er be suag'd, Whilst we did pass those hills, and dales, and downs, 'That had devour'd great ships and swallow'd towns. 'Thus after six or five hours' toil at least, We pass'd along by Wittering, west, and east, Upon the lee shore still the wind full south. We carne near Chichester's fair haven's mouth, And being then half sunk, and all through wet, More fear'd than hurt, we did the haven get. Thus in that harbour we our course did frame To Portsmouth, where on Monday morn we came. Then to the Royal Fleet we row'd aboard, Where much good welcome they did us afford. To the Lord General first my thanks shall be, His bounty did appear in gold to me, And every one aboard the Prince I found, Instead of want, to make their loves abound. Captain Penruddock there amongst the rest, His love and bounty was to us expressed, Which to requite my thankfulness I'll show, And that I'll ever pay and ever owe. On Tuesday morning we with main and might, From Portsmouth cross'd unto the Isle of Wight, By Cowes' stout castle, we to Yarmouth hasted, And still the winds' and seas' fierce fury lasted. On Wedn'sday we to Hurst's strong castle cross'd, Most dangerously sous'd, turmoil'd and toss'd. Good harbour there we found, and nothing dear,

l. Matthew Figge, a right good fellow.
I thank kind Mr. Figge ${ }^{l}$ the porter there;

He show'd us there a castle of defence,

Most useful, of a round circumference;

Of such command, that none can pass those seas

Unsunk or spoil'd, except the Castle please.

On Thursday we our boat row'd, pull'd and haul'd

Unto a place, which is Key Haven call'd.

The wind still blowing, and the sea so high,

As if the lofty waves would kiss the sky, 'That many times I wish'd with all my beart, 


\section{FROM LONDON TO SALISBURY.}

Myself, my boat and crew, all in a cart ;

Or anywhere to keep us safe and dry,

The weather raged so outrageously.

For sure I think the memory of man,

Since winds and seas to blow or flow began,

Cannot remember so stormy weather

In such continuance, held so long together.

For ten long weeks ere that 'tis manifest,

The wind had blown at south or west southwest,

And rais'd the seas ; to show each other's power,

That all this space, calm weather, not one hour,

That whether we did go by sun or moon,

At any time, at midnight, or at noon.

If we did launch, or if to land we set,

We still were sure to be half-sunk and wet.

Thus toiling of our weary time away,

That Thursday was our last long look'd for day;

For having pass'd with peril and much pain,

And plough'd and furrow'd o'er the dangerous main,

O'er depths and flats, and many a ragged rock,

We came to Christ-Church Hav'n at five o'clock.

Thus God in mercy, His just judgment sparing,

'Gainst our presumption, over-bold and daring,

Who made us see His wonders in the deep,

And that His power alone aloft did keep

Our weather-beaten boat above the waves,

Each moment gaping to be all our graves.

We sinking 'scaped: then not to us, to Him

Be all the glory, for he caused us swim.

And for his mercy was so much extended

On me, whose temptings had so far offended,

Let me be made the scorn and scoff of men,

If ever I attempt the like again.

My love, my duty, and my thankfulness,

To Sir George Hastings I must here express.

His deeds to me, I must requit in words,

No other payment poor men's state affords.

With fruitless words, I pay him for his cost,

With thanks to Mr. Templeman mine host.

So leaving Christ Church and the Haven there, 


\section{EARLY PROSE AND POETICAL WORKS.}

From 'Thetis' lap 'gan mount his flaming car. The weather kept it's course, and blow'd and rag'd,

Without appearance it would e'er be suag'd, Whilst we did pass those hills, and dales, and downs, 'That had devour'd great ships and swallow'd towns. Thus after six or five hours' toil at least, We pass'd along by Wittering, west, and east, Upon the lee shore still the wind full south. We came near Chichester's fair haven's mouth, And being then half sunk, and all through wet, More fear'd than hurt, we did the haven get. Thus in that harbour we our course did frame To Portsmouth, where on Monday morn we came. Then to the Royal Fleet we row'd aboard, Where much good welcome they did us afford. To the Lord General first my thanks shall be, His bounty did appear in gold to me, And every one aboard the Prince I found, Instead of want, to make their loves abound. Captain Penruddock there amongst the rest, His love and bounty was to us expressed, Which to requite my thankfulness I'll show, And that I'll ever pay and ever owe. On Tuesday morning we with main and might, From Portsmouth cross'd unto the Isle of Wight, By Cowes' stout castle, we to Yarmouth hasted, And still the winds' and seas' fierce fury lasted. On Wedn'sday we to Hurst's strong castle cross'd, Most dangerously sous'd, turmoil'd and toss'd. Good harbour there we found, and nothing dear,

l. Matthew figge, a right good fellow.
I thank kind Mr. Figge ${ }^{l}$ the porter there;

He show'd us there a castle of defence,

Most useful, of a round circumference;

Of such command, that none can pass those seas

Unsunk or spoil'd, except the Castle please.

On Thursday we our boat row'd, pull'd and haul'd Unto a place, which is Key Haven call'd.

The wind still blowing, and the sea so high, As if the lofty waves would kiss the sky, That many times I wish'd with all my beart, 
Myself, my boat and crew, all in a cart;

Or anywhere to keep us safe and dry,

The weather raged so outrageously.

For sure I think the memory of man,

Since winds and seas to blow or flow began,

Cannot remember so stormy weather

In such continuance, held so long together.

For ten long weeks ere that 'tis manitest,

The wind had blown at south or west south west,

And rais'd the seas; to show each other's power,

That all this space, calm weather, not one hour,

That whether we did go by sun or moon,

At any time, at midnight, or at noon.

If we did launch, or if to land we set,

We still were sure to be half-sunk and wet.

Thus toiling of our weary time away,

That Thursday was our last long look'd for day; For having pass'd with peril and much pain, And plough'd and furrow'd o'er the dangerous main,

O'er depths and flats, and many a ragged rock,

We came to Christ-Church Hav'n at five o'clock.

Thus God in mercy, His just judgment sparing,

'Gainst our presumption, over-bold and daring,

Who made us see His wonders in the deep,

And that His power alone aloft did keep

Our weather-beaten boat above the waves,

Each moment gaping to be all our graves.

We sinking 'scaped: then not to us, to Him

Be all the glory, for he caused us swim.

And for his mercy was so much extended

On me, whose temptings had so far offended,

Let me be made the scorn and scoff of men,

If ever I attempt the like again.

My love, my duty, and my thankfulness,

To Sir George Hastings I must here express.

His deeds to me, I must requit in words,

No other payment poor men's state affords.

With fruitless words, I pay him for his cost,

With thanks to Mr. Templeman mine host.

So leaving Christ Church and the Haven there, 
God, the dignity and reputation of your city, and the perpetual worthy memory of all benefactors and wellwillers unto so noble a work.

If you will but examine your own knowledges, you shall find that in the whole dominion of England there is not any one town or city which hath a navigable river at it that is poor, nor scarce any that are rich which want a river with the benefits of boats. The town of Kingston upon Hull in Yorkshire, the river there was cut out of Humber by men's labours 20 miles up into the country, and what the wealth and estate of that town is, by the only benefit of that river, it is not unknown to thousands; but you men of Sarum may see what a commodity navigation is nearer hand. There is your neighbour Southampton on the one side, and your dear friend Poole on the other, are a pair of handsome looking-glasses for you, where you may see your want in their abundance, and your negligence in their industry.

God hath placed your being in a fruitful soil, in a fruitful valley, environed round with corn, and as it were continually besieged with plenty; whilst you within, having so many poor amongst, are rather lookers upon happiness enjoyers; moreover, by God's appointment, nature hath saved you the labour of cutting a river, for I think you have one there as old as your city, ready made to your hands. If you will be but industrious to amend those impediments in it, I dare undertake to be one of the 3 or 4 men which shall bring or carry 16 or 20 tons of goods betwixt the sea and your city. Now, with extreme toil of men, horses, and carts, your wood is brought to you 18 or 20 miles, whereby the poor, which cannot reach the high prices of your fuel, are inforced to steal or starve in the winter, so that all your near adjoining woods are continually spoiled by them, which faults, by the benefit of the river, would be reformed; for the New Forest standeth so near to the water, that it is but cut the wood and put it into a boat, which shall bring as much to your city as twenty carts and fourscore horses; besides, by this river you might draw to you a trade of sea-coal, which would emrich you, and help the plain and 
inland towns and villages where no wood grows. And for the exportation of your corn from port to port within our own country, as it is well known what abundance of your barley is continually made into malt amongst you, which, if you had carriage for it, might be brewed into beer, wherewith you might serve divers places with your beer which is now served with your malt, besides carriages of bricks, tiles, stones, charcoals, and other necessaries, which are now carried at dear rates by horse and cart, which you now send in carts or on horses' backs to Southampton, to Bristol, and to many other placess, so that the dearness of the carriages eats up all your commodities and profit; which commodity may be avoided if your river be cleansed. And what man can tell what good in time may redound to your city from the sea by foreign goods, which may be brought into Christ-Church haven by shipping? nor can it be truly imagined what new and useful profitable businesses may arise in time by this means.

Our forefathers and ancestors did in their lives time in former ages do many worthy and memorable works, but for all their industry and cost, they did, or could not, do all; but as there was much done to our hands, so there was much left for us to do, and very fitting it was that it should be so, for it is against common sense and reason our father's should toil in good works like drudges, and we spend our times loitering like drones. No, what they did was for our imitation. And with all that we should be leaders of our posteriters by our examples into laudable endeavours, as our progenitors have before showed us; we are their sons and offspring, we have their shapes and figures, we bear their names, we possess their goods, inherit their lands; we have materials of stones, timber, iron, and such necessaries which they had, if not greater abundance, and having all these, let us with all have their willing and liberal hearts, and there is no question to be made, but that our river of Avon will quickly be cleaned to the honest enriching of the rich, and the charitable relieving of the poor.

I am assured there are many good men in the city, and county of Wiltshire, and others of worth and good respect 


\section{EARLY PROSE AND POETICAL WOKS.}

in this kingdom, who would willingly and bountifully assist this good work; but, like gossips near a stile, they stand straining courtesy who shall go first; or the mice in the fable, not one will adventure to hang the bell about the cat's neck; so that if one good man would begin, it would be, like a health drank to some beloved Prince at a great feast, pledged most heartily, and by God's grace effected most happily.

You have already began a charitable work amongst you, I mean your common town brewhouse, the profit of which you intend shall be wholly employed for the supply of the poor and impotents which live in your city; from which sort of people, being such a multitude, the brewers there have found their best custom; for no doubt but the meanest beggar amongst you is, in some sort, more valiant than the richest man, because the one dares to spend all he hath at the ale-house, so dares not the other; for the poor man drinks stifly to drive care away, and hath nothing to lose, and the rich man drinks moderately, because he must bear a brain to look to what he hath. And of all traders in the world, a brewer is the loadstone, which draws the customers of all functions unto it. It is the mark or upshot of every man's aim, and the bottomless whirlpool that swallows up the profits of rich and poor. The brewers' art, like a wild kestrel or un9. Some make a man'd hawk, flies at all games; or like a butler's box at profit of quarrel-Christmas, it is sure to win, whosoever loses. In a word, it their living outrules and reigns, in some sort, as Augustus Cæsar did, for and debate, it taxeth the whole earth. Your inns and alehouses are some thrive and brooks and rivers, and their clients are small rills and
grow fat by grow fat by
gluttony, manysprings, who all, very dutifully, do pay their tributes to maintained by the boundless ocean of the brewhouse. For all the world bribery, theft,
cheating,. roguery, and sufficed nature, or if it were but a little extraordinary now all together, and and then upon occasion, or by chance as you may term join to them allit; if drinking were used in any reason, or any reason else; and they used in drinking, I pray ye what would become of the
all in general are drinkers, and brewer then. Surely we do live in an age, wherein $q$ the
consequently the hituons? clianst, and estonimas: seven deadly sins are every man's trade and living. Pride is the maintainer of thousands which would else 
perish, as mercers, tailors, embroiderers, silkmen, cutters, drawers, sempsters, laundresses, of which functions there are millions which would starve but for madame pride with her changeable fashions. Lechery, what a continual crop of profit it yields, appears by the gallant thriving and gawdy outsides of many he and she, private and public sinners, both in city and suburbs. Covetousness is embroidered with extortion, and warmly lined and furred with oppression. And though it be a devil, yet is it most idolatrously adored, honoured, and worshipped by those sheep-headed fools, whom it hath undone and beggared. I could speak of other vices, how profitable they are to common-wealth ; but my invention is thirsty and must have one carouse more at the brewhouse, who, as I take it, hath a greater share than any in the gains which spring from the world's abuses ; for pride is maintained by the humble, yet one kind of pride doth live and profit by another. Lechery is supported by the cursed swarm of bawds, panders, pimps, applesquires, whores, and knaves; and so every sin lives and thrives by the members, agents, ministers, and clients, which do belong unto them, but drunkenness plays at all; all trades, all qualities, all functions and callings can be drunk extempore. Note at any great feast, or but at every ordinary dinner or supper almost, when men are well satisfied with sufficiency, that then the mystery of quaffing begins with healths to many an unworthy person, who perhaps, would not give the price of the reckoning to save all them from hanging, which make themselves sick with drinking such unthankful healths. I myself have oftentimes dined or supped at a great man's board, and when I have risen, the servants of the house have enforced me into the cellar or buttery, where, in the way of kindness, they will make a man's belly like a souse-tub, and enforce me to drink, as if they had a commission under the devil's great seal to murder men with drinking with such a deal of complimental oratory, as off with your lap, wind up your bottom, up with your taplash, and many more eloquent phrases which Tully or Demosthenes never heard of ; that in conclusion I am persuaded three days fasting would have 


\section{EARLY PROSE AND POETICAL WORKS.}

been more healthful to me than two hours feeding and swilling in that manner.

If any man hang, drown, stab, or by any violent means make away his life, the goods and lands of any such person are forfeit to the use of the king; and I see no reason but those which kill themselves with drinking should be in the same estate, and be buried in the highways with a stake drove through them. And if I had but a grant of this suit, I would not doubt but that in seven years, if my charity would agree with my wealth, I might erect almshouses, free-schools, mend highways, and make bridges ; for I dare swear that a number, almost numberless, have confessed upon their death-beds that at such and such a time, in such and such a place, they drank so much which made them surfeit, of which they languished $r$ Let theseand died.
lines be consilines be consi-
dered if I lie orman-slaughtering expenses comes to the brewer, so that not.

if a brewer be in any office, I hold him to be a very ungrateful man if he punish a drunkard ; for every stiff potvaliant drunkard is a post, beam, or pillar, which holds up the brew-house; for as the bark is to the tree, so is a good drinker to a brewer.

But you men of Salisbury, wisely perceiving how much evil to your city hath come by the abuse of good drink, you would now work by contraries to draw good for your poor out of these forepassed and present evils. To draw evil out of good is devilish, but to work or extract goodness out of what is evil is godly, and worthy to be pursued. The abuse of good drink and excessive drinking hath made many beggars amongst you, to the enriching of a few brewers, and now you would turn the world off from the barrels, as I would off from the coach-wheels, that the benefit of your new built town brewhouse might relieve many of those poor amongst you who have formerly been impoverished by the enriching of your town brewers. It is no doubt but they will oppose this good work of yours, as the image-makers in Ephesus did Paul, when he preached against their idolatrous worshipping Diana; but be not you discouraged, for Nehemiah in s. Tooiah, bians, time did build the Temple, although Sanballat and ${ }^{8}$ many
Ammonites. 
others did oppose him : for as your intents are pious, so no doubt but God will make your events prosperous.

Now to turn from beer and ale to fair water, your river, I mean, which, if it be cleansed, then with the profit of your town-brew-house and the commodity of the river, I think there will be scarce a beggar or a loiterer to be found amongst you. I have written enough before concerning the benefit of it, and to encourage such as seem slow towards so good a work, which had it been . in the Low Countries, the industrious Dutch would not so long have neglected so benéficial a blessing, witness their abundance of navigable rivers and ditches, which with the only labour of men they have cut, and in most places where never God or nature made any river; and lately there is a river made navigable to St. Yeades in Huntingdonshire, wherein stood seven mills as impediments in the way. And now the city of Canterbury are clearing their rivers, that boats may pass to and fro betwixt them and Sandwich Haven. The like is also in hand at Leeds in Yorkshire. Now, if neither former or present examples can move you, if your own wants cannot inforce you, if assured profit cannot persuade you, but that you will still be neglective and stupid, then am I sorry that I have written so much to so little purpose, but my hopes are other ways. If all blind, lame, and covetous excuses be laid aside, then those who are willing will be more willing, and those who are slack or backward will in some reasonable manner draw forward. And there is the mouth of an uncharitable objection which I must needs stop, which is an old one, and only spoken by old men; for say they, we are aged and stricken in years, and if we should lay out our moneys, or be at charges for the river, by the course of nature we shall not live to enjoy any profit to requite our costs. This excuse is worse than heathenish, and therefore it ill becomes a Christian; for as I wrote before man was not created, or had either the goods of mind, body, or fortune bestowed on him by his Maker, but that he should have the least part of them himself, his God, prince and country, claiming as their due almost all which every 


\section{EARLY PROSE AND POETICAL WORKS.}

man hath. The oldest man will purchase land, which is subject to barrenness and many inconveniences; he will buy and build houses, which are in danger of fire and divers other casualties; he will adventure upon wars or goods at high prices, which to his loss may fall to low rates; he will bargain for cattle and sheep, who are incident to many diseases, as rot, the murrain, and divers the like, and all this will he do in hope to raise his state, and leave his heirs rich. At his death perhaps when he can keep his goods no longer, when in spite of his heart he must leave all, he will give a few gowns and a little money to pious uses, a gross or two of penny loaves, and there's an end of him, so that there remains no more memory of him.

But this good work of your river is not subject to barrenness or sterility, but contrarily it will be a continual harvest of plenty. It is not in danger of being consumed or wasted, but it is assured of a perpetual increase. The names and memories of contributors toward it shall be conserved in venerable and laudable remembrance, to the eternizing of their fames, the honour of their posterities, and the good example of succeeding times to imitate. Therefore you men of Salisbury, I entreat you in this case to be good to yourselves, or else you may say hereafter, if we had been industrious, we had been happy; if we had not been covetous, we had been rich.

Now to return to my travels and entertainments. As I passed up the river, at the least 2000 swans like so many pilots swam in the deepest places before me, and showed me the way. When I came to the town of Ringwood, 14 miles short of Salisbury, I there met with His Majesties Trumpeters, and there my fellows, Mr. Thomas Underhill and Mr. Richard Stock, Mr. Thomas Ramsey, Mr. Randall Lloyd, with others which I name not did walk on the bank, and gave me two excellent flourishes with their trumpets, for the which I thank them in print and by word of mouth. At last I came to a town called Fording Bridge, where not many days before, a grievous mischance happened. For two men being swimming or washing in the river, a butcher passing over 
the bridge, with a mastiff dog with him, did cast a stone into the water and say-a duck; at which the dog leaped into the river and seized upon one of the men and killed him; and the butcher leaping in after, thinking to save the man, was also slain by his own dog; the third man also hardly escaping, but was likewise bitten by him.

From thence I passed further to a place called Hale, where we were welcomed by the Right Worshipful Sir Thomas Penrudduck, Knight, whom we carried there in our boat, and who, I am assured, will be a forward and a liberal benefactor towards clearing of the river.

So passing on our course by the villages of Burgate Breamore, Charford, Downton, and Stonely, we came to Langford, where we were well entertained by the Right Honourable the Lord Edward George, Lord Baron of Dundalk, and Captain of his strong and Majesties defencible Castle of Hurst, in Hampshire, to whom in love and duty we proffered the gift of our tattered, wind-shaken and weather-beaten boat, which, after our being at Salisbury, being but two miles from thence, his Lordship accepted. And though he knew she was almost unserviceable, yet his noble bounty was such, that he rewarded us with the price of a new boat. I had some conference with his honour concerning the impediments and cleansing of the river, and I know he is most forwardly and worthily affected towards it, and no doubt if it be pursued, that then he will do that which shall become a gentleman of his honourable calling and rank.

So on the same Friday at night we came to Salisbury, where we brought our boat through Fisherton bridge, on the west side of the city, taking our lodging at the sign of the king's head there, with mine host, Richard Estman, whose brother Thomas, was one of the watermen which came in the boat thither from London. On the morrow, I with my company footed it two miles to Wilton, where at the Right Honourable the Earl of Pembrokes, my Lord Chamberlain's house, I was most freely, and beyond my worth and merit, kindly welcomed by the Right Worshipful Sir Thomas Morgan, knight, with whom I dined, and by whose command I was showed all or the most part of the 


\section{EARLY PROSE AND POETICAL WORKS.}

admirably contrived rooms in that excellent and wellbuilt house; which rooms were all richly adorned with costly and sumptuous hangings; his Majesty some few days before having dined there with most magnificent entertainment, as did express the love of so noble a housekeeper for so royal a guest, upon the sight of which house with the furniture I wrote these following verses :

If wholesome air, earth, woods, and pleasant springs Are elements whereby a house is grac'd,

If strong and stately built contentment brings,

Such is the house of Wilton, and so plac'd.

There nature, art, art nature hath embrac'd;

Without, within, below, aloft complete ;

Delight and state are there so interlac'd

With rich content, which makes all good and great.

The hangings there, with histories replete,

Divine, profane, and moral pleasures giving.

With work so lively, exquisite, and neat,

As if man's art made mortal creatures living.

In brief, there all things are compos'd so well,

Beyond my pen to write or tongue to tell. .

Then I was showed a most fair and large armoury, with all manner of provision and furniture, for pike, shot, bills, halberts, javelins, with other weapons and munition, which for goodness, number, and well-keeping, is not second to any nobleman's in England. Afterwards I went to the stables and saw my lord's great horses, whom I saw such and so good, that what my untutored pen cannot sufficiently commend I am forced with silence to overpass. But amongst the rest, the pains and industry of an ancient gentleman, Mr. Adrian Gilbert, must not be forgotten, for there hath he, much to my lord's cost and his own pains, used such a deal of intricate setting, grafting, planting, innoculating, railing, hedging, plashing, turning, winding, and returning circular, triangular, quadrangular, orbicular, oval, and every way curiously and chargeably conceited; there hath he made walks, hedges, and arbours, of all manner of most delicate fruit trees, planting and placing them in such admirable art- 
like fashions, resembling both divine and moral remembrances, as three arbours standing in a triangle, having each a recourse to a greater arbour in the midst, resembleth three in one, and one in three; and he hath there planted certain walks and arbours all with ${ }^{t}$ fruit trees $\mathrm{so}_{\text {stands there but }}^{t .}$ Not a tree pleasing and ravishing to the sense, that he calls it Para-itbearsone good dise, in which he plavs the part of true Adamist, con- or rare fruit or tinually toiling and tilling. Moreover, he hath made his walks most rarely round and spacious, one walk without another, as the rinds of an onion are greatest without and less towards the centre, and withal the hedges betwixt each walk are so thickly set that one cannot see through from the one walk who walks in the other. That in conclusion, ${ }^{u}$ the work seems endless, and I think that in $u$. A round work England it is not to be fellowed, or will in haste behaving no end. followed. And in love which I bear to the memory of $\mathrm{so}_{\text {matchless }}^{\mathrm{I} \text { tout }}$ the industrious and ingenious a gentleman, I have written adjoining wood the following anagrams:

Adryan Gilbert, $\}$ Anagrams. $\left\{\begin{array}{l}\text { Art redily began } \\ \text { A breeding tryall. }\end{array}\right.$ Rowlington here, whose praises consists in itself, my pen being insufficient.

Art redily began a breeding tryall,

When she inspir'd this worthy gentleman;

For Nature's eye of him took full espiall,

And taught him art, art readily began,

That though Dame Nature was his tutoress, he

Outworkes her, at his workes apparent be.

For Nature brings but earth and seeds and plants, Which art, like tailors, cuts and puts in fashion;

As Nature rudely doth supply our wants,

Art is deformed Nature's reformation.

So Adryan Gilbert mendeth Nature's features

By art, that what she makes doth seem his creatures.

THUs with my humble thanks to Sir Thomas Morgan, and my kind remembrance to all the rest of my lord's servants there, my legs and my labouring lines return again to Salisbury, and from the next day, being Sunday, to Langford, to my Lord George his house, with whom I dined and left my humble thanks for the reckoning. In 


\section{EARLY PROSE AND POETICAL WORKS.}

brief, my fruitless and worthy lip-labour, mix'd with a deal of airy and non-substantial matter, I gave his lordship and the like requital I bestowed on the right Worshipful Mr. Thomas Squibb, Mayor of Sarum, with Mr. Banes, Mr. John Ivy, Mr. Windour, with all the rest ; and more than thanks and a grateful remembrance of their honourable, worshipful, and friendly favours, I know they expect not, and less than such a common duty as gratitude I must not or cannot pay. To shut up all in few words, I know his Majesty's pious inclination is so ample that he will be graciously pleased with any of your laudable endeavours for your welfare and commodity if you take good and speedy advice, then no doubt but the effects will be according to your honest intendments.

So farewell Salisbury till we meet again, which I hope will be one day ; in the mean space I pray thee take this poor pamphlet as a loving pledge of my return. Methinks I see already men, horses, carts, mattocks, shovels, spades, wheelbarrows, handbarrows, and baskets at work for the clearing of your river; but if my thoughts do deceive me, and my expectation fail, I shall ever hereafter give small credit to their intelligence. So once more Salisbury I wish thee thankfully well to fare.

On Thursday the 21st of August, I took Winchester in my way homewards, where I saw an ancient city, like a body without a soul; and I know not the reason of it, but for ought which I perceived, there were almost as many parishes as people. I lodged at the sign of the Cock, being recommended to the host of the house by a token from Salisbury; but mine host died the night before I came, and I being weary had more mind to go to bed than to follow him so long a journey, to do my message or deliver any commendations. But the whole city seemed almost as dead as mine host, and it may be they were all at harvest work. But I am sure I walked from one end of it to the other, and saw not thirty people of all sorts. So that I think if a man should go to Winchester for a goose, he might lose his labour, for a trader cannot live there by vending such commodities. $>$ On Friday I galloped a foot pace one and twenty 
miles, from Winchester to Farnham, where I and one of my company hired a couple of Hampshire jenets, with seven legs and three eyes betwixt them, upon whom we hobbled seventeen miles to Staines, whence on Saturday the 23rd of August we footed it to Brentford, and boated it to London. 



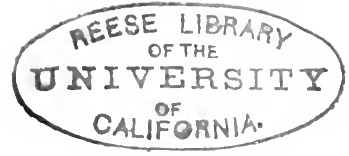

\section{THE UNNATURAL FATHER}

OR

A CRUEL MURDER

Committed by one John Rouse of the Town of Ewell, ten miles from London, in County of Surrey UPON TWO OF HIS OWN CHILDREN 

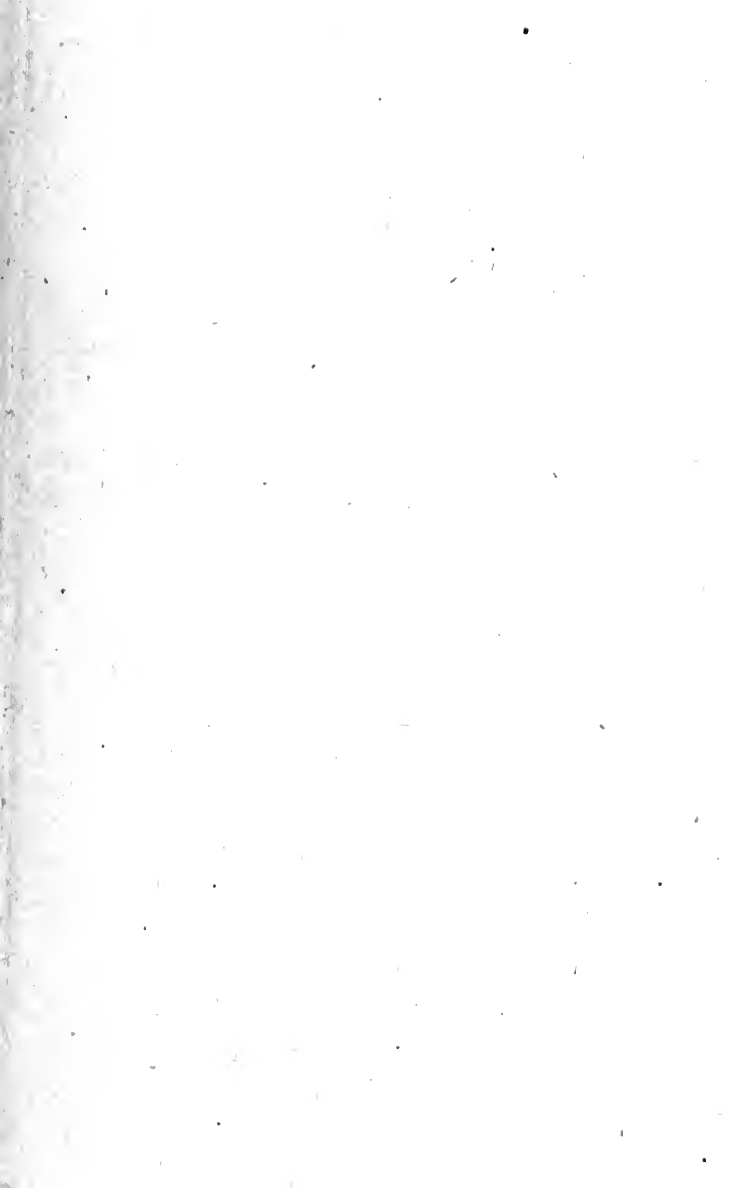


\section{THE UNNATURAL FATHER.}

As a chain consists of divers links, and every link depends, and is inyoked upon one another, even so our sins, being the chain wherewith Satan doth bind and manacle us, are so . knit, twisted, and soldered together, that without our firm faith ascending, and God's grace descending, we can never be freed from those infernal fetters; for sloth is linked with drunkenness, drunkenness with fornication and adultery, and adultery with murder, and so of all the rest of the temptations, suggestions, and actions, wherewith miserable men and women are insnared and led captive into perpetual perdition, except the mercy of our gracious God be our defence and safeguard.

For a lamentable example of the devil's malice, and man's misery; this party, of whom I treat at this time, was a wretch, not to be matched, a fellow not to be fellowed, and one that scarce hath an equal, for matchless misery, and unnatural murder. But to the matter.

This John Rowse being a fishmonger in London, gave over his trade and lived altogether in the town of Ewell, near Nonsuch, in the county of Surrey, ten miles from London, where be had land of his own for himself and his heirs for ever to the value of fifty pounds a year, with which he lived in good and honest fashion, being well reputed of all his neighbours, and in good estimation with gentlemen and others that dwelt in the adjoining villages.

Until at the last he married a very honest and comely woman, with whom he lived quietly and in good fashion some six months, till the devil sent an instrument of his to disturb their matrimonial happiness; for they wanting a maidservant, did entertain into their house a wench, whose name was Jane Blundell, who in short time was better acquainted with her master's bed than honesty required, which in time was found out and known by her mistress, and brake the peace, in such sort, between the said Rowse and his wife, that in the end, after two year's continuance, it brake the poor woman's heart, that she died and left her husband a widower, where he and his 


\section{EARLY PROSE AND POETICAL WORKS.}

whore were the more free to use their cursed contentments, and ungodly embracements.

Yet that estate of being unmarried, was displeasing to him, so that he took to wife another woman, who for her outward feature, and inward qualities was every way fit for a very honest man, although it were her hard fortune to match otherwise.

With this last wife of his he lived much discontented, by reason of his keeping his lewd trull in his house, so that by his daily riot, excessive drinking and unproportionable spending, his estate began to be much impoverished, much of his land mortgaged and forfeited, himself above two hundred pounds indebted, and in process of time to be, as a lewd liver, of all his honest neighbours rejected and contemned.

His estate and credit being almost past recovery wasted and impaired, he forsook his wife, came up to London with his wench, where he fell into a new league with a corrupted friend; who, as he said, did most courteously cozen him of all that ever he had, and whom at this time I forbear to name, because it was John Rowse his request before his execution, that he should not be named in any book or ballad, but yet upon a die his name may be picked out betwixt a Cinq and a Trois. This false friend of his, as he said, did persuade him to leave his wife for altogether, and did lodge and board him and his paramour certain weeks in his house, and afterward caused him and her to be lodged, having changed his name, as man and wife in an honest man's house near Bishops-gate, at Bevis Marks.

Where they continued so long, till his money was gone, as indeed he never had much; but now and then small petty sums from his secret friend aforesaid, and he being fearful to be smooked out by his creditors, was counselled to leave his country and depart for Ireland. And before his going over sea, his friend wrought so, that all his land was made over in trust to him, and bonds, covenants, and leases made, as fully bought and sold for a sum of two hundred and threescore pounds. Of all which money the said Rowse did take the Sacrament at his death, that he 
never did receive one penny, but he said now and then he had five or ten shillings at a time from his said friend, and'never above twenty shillings. And all that ever he had of him, being summed together, was not above three and twenty pounds, the which moneys his friend did pay himself out of his rents. But some more friend to him, than he was to himself, did doubt that he was cheated of his land; whereupon, to make all sure, he said that his false friend did so far prevail with him, that he the said Rowse took an oath in the open court at Westminster Hall, that he had lawfully sold his land, and had received the sum above said, in full satisfaction and payment, and his said friend did vow and protest many times unto him, with such oaths, and vehement curses, that he never would deceive his trust, but that at any time when he would command all those forged bonds and leases, that he would surrender them unto him, and that he should never be damnified by them or him, to the value of one half penny. Upon which protestations, he said, he was enticed to undo himself out of all his earthly possessions, and by a false oath to make hazard of his inheritance in heaven.

In Ireland he staid not long, but came over again, and was by his friend persuaded to go into the low countries; which he did, never minding his wife and two small children which he had by her, having likewise a brace of bastards by his whore, as some say, but he said that but one of them was of his begetting. But he, after some stay in Holland, saw that he could not fadge there, according to his desire and withal, suspecting that he was cheated of his land, and above all, much perplexed in his conscience for the false oath that he had taken, pondering his miserable estate, and rueing his unkindness to his wife, and unnatural dealing to his children, thinking with himself 'what course were best to take to help himself out of so many miseries which did incompass him, he came over again into England to his too dear friend, demanding of him his bonds and leases of his land which he had put him in trust withal. But then his friend did manifest himself what he was, and told him plainly, that he had no 


\section{EARLY PROSE AND POETICAL WORKS.}

writings, nor any land of his, but what he had dearly bought and paid for. All which, Rowse replied unto him, was false, as his own conscience knew. Then said the other, have I not here in my custody your hand and seal to confirm my lawful possession of your land? and moreovier, have I not a record of an oath in open court, which you took concerning the truth of all our bargain? And seeing that I have all these especial points of the law, as an oath, indentures, and a sure possession, take what course you will, for I am resolved to hold what I have.

These, or the like words, in effect passed betwixt Rowse and his friend, trusty Roger, which entering at his ears, pierced his heart like daggers; and being out of money and credit, a man much infamous for his bad life, indebted beyond all possible means of payment, a perjured wretch to cozen himself, having no place or means to feed or lodge, and fearful of being arrested, having so much abused his wife, and so little regarded his children, being now brought to the pit's brim of desperation, not knowing amongst these calamities which way to turn himself, he resolved at last to go home to Ewell again to his much wronged wife for his last refuge in extremity.

The poor woman received him with joy, and his children with all gladness welcomed home the prodigal father, with whom he remained in much discontentment and perplexity of mind. The devil still tempting him to mischief and despair, putting him in mind of his former better estate, comparing pleasures past with 'present miseries; and he revolving that he had been a man in that town, had been a gentleman's companion of good reputation and calling, that he had friends, lands, money, apparel, and credit, with means sufficient to have left for the maintenance of his family, and that now he had nothing left him but poverty and beggary, and that his two children were like to be left to go from door to door for their living.

Being thus tormented and tossed with restless imaginations, he seeing daily to his further grief, the poor case of his children, and fearing that worse would befall them hereafter, he resolved to work some means to take away 
their languishing lives by a speedy and untimely death, the which practice of his, by the devil's instigation and assistance, he effected as followeth.

To be sure that nobody should stop or prevent his devilish enterprise, he sent his wife to London on a frivolous errand for a riding coat; and she being gone somewhat timely and too soon in the morning, both her children being in bed and fast asleep, being two very pretty girls, one of the age of six years, and the other four years old, none being in the house but themselves, their unfortunate father and his ghostly counsellor, the doors being fast locked; he having an excellent spring of water in the cellar of his house, which to a good mind that would have employed it well would have been a blessing, for the water is that of crystalline purity and clearness, that Queen Elizabeth of famous memory would daily send for it for her own use, in which he purposed to drown his poor innocent children sleeping. For he going into the chamber where they lay, took the youngest of them named Elizabeth forth of her bed and carried her down the stairs into his cellar, and there put her in the spring of water, holding down her head under that pure element with his hands, till at last the poor harmless soul and body parted one from another.

Which first act of this his inhuman tragedy being ended, he carried the dead corpse up three pair of stairs, and laying it down on the floor, left it, and went down into the chamber where his other daughter named Mary was in bed; being newly awakened, and seeing her father, demanded of him where her sister was? To whom he made answer that he would bring her where she was. So taking her in his arms he carried her down towards the cellar, and as he was on the cellar stairs she asked him what he would do, and whither he would carry her? Fear nothing, my child, quoth he, I will bring thee up again presently; and being come to the spring, as before he had done with the other, so he performed the last unfatherly deed upon her; and to be as good as his word, carried her up the stairs and laid her by her sister. That done, he laid them out and covered them both with a 


\section{EARLY PROSE AND POETICAL WORKS.}

sheet, walking up and down his house weeping and lamenting his own misery and his friend's treachery, that was the main ground of all his misfortunes and the death of his children; and though there was time and opportunity enough for him to fly, and to seek for safety, yet the burthen and guilt of his conscience was so heavy to him, and his desperate case was so extreme, that he never offered to depart, but as a man weary of his life, would, and did stay, till such time as he was apprehended and sent to prison, where he lay till he was rewarded with a just deserved death.

What his other intents were after he had drowned his children is uncertain, for he drew his sword and laid it naked on a table, and after he gat a poor woman down into the cellar, and in the same place where the two infants lost their lives, he did help the woman to wring a buck of his clothes, and then he requested her to help to convey his goods out of his house, for he said that he feared that the sheriff of Surrey would come and seize upon all. But the woman not thinking of any of the harm that was done, imagined that he had meant that his goods would be seized for debt and not for murder.

But to return to the miserable mother of the murdered children, she said that her heart throbbed all the day, as fore-boding some heavy mischance to come; and having done her business that she came about to London, as soon as she came home she asked for her children, to whom her husband answered that they were at a neighbour's house in the town. 'Then said she, I will go thither to fetch them home. No, quoth he, I will go myself presently for them. Then said his wife, let the poor woman that is here go and bring them home. But at last she saw such delay was used, she was going herself, then her husband told her that he had sent them to a kinsman's of his at a village called Sutton, four miles from Ewell, and that he provided well for them. and prayed her to be contented and fear nothing for they were well. These double tales of his made her to doubt somewhat was amiss, therefore she entreated him for God's sake to tell her truly where they were. Whereupon he said, "If you will needs know 
where they are, go but up the stairs into such a chamber and there you shall find them. But in what a lamentable perplexity of mind the poor woman was when she perceived how and which way they lost their lives, any Christian that hath an heart of flesh may imagine. Presently the constable was sent for, who took him into his custody, who amongst other talk, demanded of him why and how he could commit so unnatural a fact as to murder his children? To whom he answered that he did it because he was not able to keep them, and that he was loth they should go about the town a begoing; and moreover, that they were his own, and being so, that he might do what he would with them, and that they had their lives from him, and therefore he had taken their lives from them, and was contented to lose his life for them ; for he was sure that their miseries were past, and for his part, he had an assured hope to go to them, though they could not come to him.

So being had before justice his examination was very brief, for he confessed all the whole circumstances of the matter freely, so that he was sent to the common prison of Surrey called the White Lion, where he remained fourteen or fifteen weeks a wonderful penitent prisoner, never, or very seldom, being without a bible or some other good book meditating upon; and when any one did but mention his children, he would fetch a deep sigh and weep, desiring every one to pray for him; and upon his own earnest request, he was prayed for at Paul's Cross, and at most of the churches in London, and at many in the country, and at the Sessions holden at Croydon the latter end of June last. He made such free confession at the bar, declaring the manner of his life, his odious drinking, his abominable whoring, his cruel murder, and the false dealing of his deceitful friend, which was the cause of his final wreck, with which relations of his pronounced with such vehemency and protestations, he moved all that heard him to commiseration and pity.

So according to law and justice, he was there condemned and judged for the murdering of his two children to be hanged; which judgment was executed on him at 


\section{EARLY PROSE AND POETICAL WORKS.}

the common gallows at Croyden, on Monday the second day of June, 1621 , where he died with great penitency and remorse of conscience.

This was the lamentable end of John Rowse, a man of the age of fifty years, and one that might have lived and died in better fashion, if he had laid hold on the grace of heaven, and craved God's protection and fatherly assistance. But of all that herein is declared, this one thing which I now declare, is most lamentable and remarkable, which is that Ewell being a market town not much above ten miles from London, in a Christian kingdom, and such a kingdom where the all-saving Word of the ever-living God is most diligently, sincerely, and plentifully preached; and yet amidst this diligence, as it were in the circle or centre of his sincerity, and in the flood of this plenty, the town of Ewell hath neither preacher nor pastor. For although the parsonage be able to maintain a sufficient preacher, yet the living being in a layman's hand, is rented out to another for a great sum, and yet no preacher maintained there. Now the chief landlord out of his portion doth allow but seven pounds yearly for a reader, and the other that doth hire the parsonage at a great rent doth give the said reader four pounds the year more out of his means and courtesy. And by this means the town is served with a poor old man that is half blind, and by reason of his age can scarcely read. For all the world knows that so small a stipend cannot find a good preacher, books, and very hardly bread to live on; so that the poor souls dwelling there are in danger of famishing for want of a good preacher to break the Bread of Life unto them. For a sermon amongst them is as rare as warm weather in December or ice in July; both which I have seen in England though but seldom.

And as the wolf is most bold with the sheep when there is either no shepherd or an impotent, insufficient one, so the devil perhaps took bis advantage of this wretched man, seeing he was so badly guarded and so weakly guided to withstand his force and malice; for where God is least known and called upon, there Sátan hath most power and domination. But howsoever, I wish with all 
my heart, that that town and many more were better provided than they are, and then such numbers of souls would not be in hazard to perish ; nor so many sufficient scholars that can preach and teach well, live in penury through want of maintenance. I could run further upon this point, but that I shortly purpose to touch it more to the quick in another book.

By this man's fall we may see an example of God's justice against drunkenness, whoredom and murder. The devil being the first author, who was a murderer from the beginning; who filled Cain with envy that he murdered his brother Abel; who tempted David first to adultery and afterwards to murder; who provoked Herod to cause the blessed servant of God, John Baptist, to lose his head, because he told him it was not lawful for him to marry his brother Philip's wife ; and who was the provoker of the aforesaid Herod to murder all the innocent male children in his kingdom. And let us but mark and consider the plagues aud punishments that God hath inflicted upon murderers, adulterers, and incestuous persons. First Cain, although by his birth he was the first man that ever was born, a prince by his birth, and heir apparent to all the world, yet for the murder by him committed on his brother, he was the first vagabond and runagate on the face of the earth, almost fearful of his own shadow; and after he had lived a long time terrified in conscience, was himself slain, as is supposed, by Lamech, Simeon, and Levi. The sons of Jacob were accursed of their Father for the slaughter of the Sichemites; Joab, the captain of David's host, was slain for the murdering of Abner; David himself, for the death of Urias and the adultery committed with Bethsheba, was continually plagued and vexed with the sword of war, with the rebellion of his own sons, and with the untimely deaths of Amnon and Absalom. Bannah and Rechab, for the slaying of Ishbosheth the son of Saul, they were both by David's commandment put to death, who had both their hands and feet cut off, and were afterwards hanged over the Pool-in Hebron, (Samuel, 2, 4.) The examples are infinite out of divine and human histories, that God 


\section{EARLY PROSE AND POETICAL WORKS.}

did never suffer murder to go unrewarded; and this miserable man, of whom I have here related, is a most manifest spectacle of God's revenging vengeance for that crying and heinous sin.

As concerning lust and incontinency, it is a short pleasure bought with long pain, a honeyed poison, a gulf of shame, a pickpurse, a breeder of diseases, a gall to the conscience, a corrosive to the heart, turning man's wit into foolish madness, the body's bane and the soul's perdition. It is excessive in youth and odious in age, besides God himself doth denounce most fearful threats against fornicators and adulterers, as the apostle saith, that whoremongers and adulterers shall not inkerit the kingdom of heaven, $(1$ Cor. 6,9$)$. And God himself saith, that he will be a swift witness against adulterers, (Mal. 3,5). And the wise man saith, that because of the whorish woman, a man is brought to a morsel of bread, and a woman will hunt for the precious life of a man; for saith he, can a man take fire in his bosom, and his clothes not be burnt? or can a man go up on hot coals, and his feet not be burnt? So he that goeth into his neighbour's wife, shall not be innocent, (Prov. 6, 27, 28, 29). Abimelech, one of the sons of Gideon, murdered three-score and ten of his brethren, and in reward thereof, by the just judgment of God, a woman with a piece of a milistone beat out his brains, after he had usurped the kingdom three years, (Judges 9th). Our English chronicles make mention that Roger Mortimer, Lord Baron of Wallingford, murdered his master, King Edward the second, and caused the King's uncle, Edmund, Earl of Kent, causelessly to be beheaded; but God's justice overtook him at last, so that for the said murders he was shamefully executed. Humphrey, Duke of Gloucester, was murdered is the Abbey of Bury by William de la Poole, Duke of Suffolk, who. afterwards was beheaded himself on the sea by a pirate. Arden of Feversham, and Page of Plymouth, both their murders are fresh in memory, and the teartul ends of their wives and their aiders in those bloody actions will never be forgotten.

It is too manifestly known what a number of step- 
mothers and strumpets have most inhumanly murdered their children, and for the same have most deservedly been executed. But in the memory of man, nor scarcely in any history, it is not to be found that a father did ever take two innocent children out of their beds, and with weeping tears of pitiless pity and unmerciful mercy, to drown them, showing such compassionate cruelty and sorrowful sighing, remorseless remorse in that most unfatherly and unnatural deed.

All which may be attributed to the malice of the devil, whose will and endeavour is that none should be saved who lays out his traps and snares, entangling some with lust, some with covetousness, some with ambition, drunkenness, envy, murder, sloth or any vice whereto he sees a man or a woman most inclined unto, as he did by this wretched man lulling him, as it were, in the cradle of sensuality and ungodly delight, until such time as all his means, reputation, and credit was gone, and nothing left him but misery and reproach. Then he leads him along through doubts and fears to have no hope in God's providence, persuading his conscience that his sins were unpardonable, and his estate and credit unrecoverable.

With these suggestions he led him on to despair, and in desperation to kill his children and make shipwreck of his own soul, in which the diligence of the devil appeareth, that he labours and travels incessantly; and as Saint Beruard saith, in the last day shall rise in condemnation against us, because he hath ever been more diligent to destroy souls than we have been to save them. And for a conclusion, let us beseech God of his infinite mercy to defiend us from all the subtle temptations of Satan.

JOHN Rowse his prayer for pardon of his lewd life, which he used to pray in the time of his imprisonment.

GoD of my soul and body, have mercy upon me; the one I have cast away by my folly, and the other is likely to perish in thy fury, unless in thy great mercy thou save it. Mly sius are deep seas to drown me; I am swallowed up in the bottomless gulf of my own transgressions. With 


\section{EARLY PROSE AND POETICAL WORKS.}

Cain I have been a murderer, and with Judas a betrayer of the innocent. My body is a slave to Satan, and my wretched soul is devoured up by hell. Black have been my thoughts, and blacker are my deeds. I have been the devil's instrument, and am now become the scorn of men; a serpent upon earth, and an outcast from heaven. What therefore can become of me, miserable caitiff? If I look to my Redeemer, to him I am an arch-traitor, if upon earth, it is drowned with blood of my shedding, if into hell, there I see my conscience burning in the brimstone lake. God of my soul and body have mercy therefore upon; save me, $O$ save me, or else I perish for ever. I die for ever in the world to come, unless, sweet Lord, thou catchest my repentant soul in thine arms. O save me, save me, save me.

JOHN ROwSE of Ewell, his own arraignment, confession, condemnation, and judgment of himself whilst he lay prisoner in the White Lion, for drowning of his two children.

I AMr arraign'd at the black dreadful bar, Where sins, so red as scarlet, judges are; All my indictments are my horrid crimes, Whose story will affright succeeding times, As, now, they drive the present into wonder, Making men tremble as trees struck with thunder. If any asks what evidence comes in?

$\mathbf{O}$ 'tis my conscience, which hath ever been

A thousand witnesses: and now it tells

A tale, to cast me to ten thousand hells. The jury are my thoughts, upright in this, They sentence me to death for doing amiss:

Examinations more there need not then, Than what's confess'd here both to God and men.

That crier of the court is my black shame, Which when it calls my jury doth proclaim, Unless, as they are summon'd, they appear, To give true verdict of the prisoner, They shall have heavy fines upon them set, 
Such, as may make them die deep in heaven's debt; About me round sit and innocence and truth, As clerks to this high court; and little Ruth From peoples eyes is cast upon my face, Because my facts are barbarous, damn'd and base.

The officers that 'bout me, thick, are plac'd, To guard me to my death, when I am cast, Are the black stings my speckled soul now feels, Which like to furies dog me, close at heels. The hangman that attends me, is despair, And gnawing worms my fellow-prisoners are.

\section{His Indictment for Murder of his Children.}

THe first who, at this Sessions, loud doth call me Is murder, whose grim visage doth appal me; His eyes are fires, his voice rough wind out-roars, And on my head the Divine vengeance scores; So fast and fearfully I sink to ground, And wish I were in twenty oceans drown'd. He says, I have a bloody villain been, And, to prove this, ripe evidence steps in, Brow'd like myself, justice so brings about, That black sins still hunt one another out; 'Tis like a rotten frame ready to fall, For one main post being shaken, pulls down all.

To this indictment, holding up my hand, Fettered with terrors more than irons stand, And being asked what to the bill I say, Guilty, I cry. O dreadful Sessions day!

\section{His Judgment.}

- For these thick Stygian streams in which th'ast swom, Thy guilt hath on thee laid this bitter doom; Thy loath'd life on a tree of shame must take A leave compelled by law, e'er old age make Her signed pass-port ready. Thy offence No longer can for days on earth dispense. Time blot thy name out of this bloody roll, And so the Lord have mercy on my soul. 


\section{EARLY PROSE AND POETICAL WORKS.}

His speech what he could say for himself.

O WRETCHED caitiff! what persuasive breath,

Can call back this just sentence of quick death ?

I beg no boon, but mercy at God's hands,

The King of Kings, the Sovereign that commands

Both soul and body, O let him forgive

My treason to his throne, and whilst I live,

Jibbets and racks shall torture limb by limb,

Through worlds of deaths I'll break to fly to him.

My birth-day gave not to my mother's womb,

More ease, than this shall joys, whene'er it come.

My body mould to earth, sins sink to hell,

My penitent soul win heaven, vain world farewell. 


\section{T H E O L D, O L D VERY OLD MAN}

OR

The Age and long Life of Thomas Parr, the son of John Parr of Winnington, in the Parish of Alberbury, in the Salopp. Who was born in the reign of King Edward Fourth, being aged 152 years and odd months.

His Manner of Life and Conversation in so long a Pilgrimage. His marriages, and his bringing up to London about the end of September last 1635.

Whereunto is added a Postscript showing the many remarkable incidents that happened in the Life of the Old Man. 


\section{THE HIGH AND MIGHTY PRINCE CHARLES,}

By the Grace of God, King of Great Britain, France, and Ireland, Defender of the Faith, etc.

OF subjects; my dread liege, 'tis manifest, You have the old'st, the greatest, and the least.

That for an old, a great, and little man, No kingdom, sure, compare with Britain can; One, for his extraordinary stature, Guards well your gates, and by instinct of nature, As he is strong, is loyal, true, and just, Fit, and most able, for his charge and trust. The other's small and well composed feature Deserves the title of a pretty creature; And doth, or may, retain as good a mind As greater men, and be as well inclined. He may be great in spirit, though small in sight, Whilst all his best of service, is delight. The old'st, your subject is ; but for my use, I make him here, the subject of my muse; And as his aged person gain'd the grace, That where his sovereign was, to be in place, And kiss your royal hand; I humbly crave, His life's description may acceptance have. And as your majesty_hath oft before Look'd on my poems; pray read this one more. Your Majesty's most Humble Subject and Servant, JOHN TAYLOR. 


\section{THE OCCASION OF THIS OLD MAN'S BEING BROUGHT OUT OF SHROPSHIRE TO LONDON.}

As it is impossible for the sun to be without light, or fire to have no heat, so is it undeniable that true honour is as inseparably addicted to virtue as the steel to the loadstone; and without great violence neither the one or the other can be sundered. Which manifestly appears, in the conveying out of the country of this poor ancient man, monument I may say, and almost miracle of nature.

For the Right Honourable Thomas, Earl of Arundel and Surrey, Earl Marshal of England, etc., being lately in Shropshire to visit some lands and manors which his lordship holds in that county, or for some other occasions of importance, which caused his lordship to be there. The report of this aged man was certified to his honour; who hearing of so remarkable a piece of antiquity, his lordship was pleased to see him, and in his innated noble and Christian piety, he took him into his charitable tuition and protection; commanding that a litter and two horses, for the more easy carriage of a man so enfeebled and worn with age, to be provided for him. Also, that a daughter-in-law of his, named Lucy, should likewise attend him, and have a horse for her own riding with him; and, to cheer up the old man, and make him merry, there was an antique-fac'd-fellow, called Jack or John the Fool, with a high and mighty no beard, that had also a horse for his carriage. 'these all were to be brought out of the country to London by easy journeys; the charges being allowed by his lordship, and likewise one of his honour's own servants, named Bryan Kelly, to ride on horseback with them, and to attend and defray all manner of reckonings and expenses; all which was done accordingly, as followeth.

Winnington is a hamlet in the parish of Alberbury, near a place called the Welsh Pool, eight miles from Shrewsbury, from whence he was carried to Wim, a town of the Earl's aforesaid; and the next day to Shefnall, a Manor House of his lordship, where they likewise staid 
one night. From Shefnall they came to Wolverhampton, and the next day to Brimicham, from thence to Coventry; and although Master Kelly had much to do to keep the people off that pressed upon him in all places where he came, yet at Coventry he was most oppressed; for they came in such multitudes to see the old man, that those that defended him were almost quite tired and spent, and the aged man in danger to have been stifled; and in a word, the rabble were so unruly that Bryan was in doubt he should bring his charge no further; so greedy are the vulgar to hearken to, or gaze after novelties. The trouble being over, the next day they passed to Daventry, to Stony Stratford, to Redburn, and so to London, where he is well entertained and accommodated with all things, having all the aforesaid atteudants, at the sole charge and cost of his lordship.

One remarkable passage of the old man's policy must not be omitted or forgotten, which is thus.

His three leases of 63 years being expired, he took his last lease of his landlord, one Master John Porter, for his life, with which lease he hath lived more than 50 years as is further hereafter declared; but this old man would, for his wife's sake, renew his lease for years, which his landlord would not consent unto. Wherefore old Parr, having been long blind, sitting in his chair by the fire, his wife looked out of the window and perceived Master Edward Porter, the son of his landlord, to come towards their house, which she told her husband, saying, "Husband our young landlord is coming hither." "Is he so," said old Parr; "I prithee wife lay a pin on the ground near my foot, or at my right toe," which she did, and when young Master Porter, yet forty years old, was come into the house, after salutations between them, the old man said, "Wife, is not that a pin which lies at my foot?" " 'Truly, husband," quoth she, "it is a pin indeed;" so she took up the pin, and Master Porter was half in a maze that the old man had recovered his sight again. But it was quickly found to be a witty conceit, thereby to have them to suppose him to be more lively than he was, 
because he hoped to have his lease renewed for his wife's sake, as aforesaid.

He hath had two children by his first wife, a son and a daughter. The boy's name was John, and lived but ten weeks; the girl was named Joan, and she lived but three weeks. So that it appears he hath out-lived the most part of the people that are living near there, three times over.

\section{THE VERY OLD MAN : \\ OR}

THE LIFE OF THJMAS PARR.

AN old man's twice a child, the proverb says, And many old men ne'er saw half his days

Of whom I write; for he at first had life

When York and Lancaster's domestic strife

In her own blood had factious England drench'd,

Until sweet peace those civil flames had quench'd.

When as fourth Edward's reign to end drew nigh,

John Parr, a man that liv'd by husbandry,

Begot this Thomas Parr, and born was he

The year of fourteen hundred eighty three.

And as his father's living and his trade

Was plough, and cart, scythe, sickle, bill, and spade,

The harrow, mattock, flail, rake, fork, and goad,

And whip, and how to load and to unload,

Old Tom hath shew'd himself the son of John,

And from his father's function hath not gone.

Yet I have read of as mean pedigrees,

That have attain'd to noble dignities.

Agathocles, a potter's son, and yet

The kingdom of Sicily he did get.

Great Tamberlane, a Scythian shepherd was,

Yet in his time, all princes did surpass.

First Ptolomy, the king of Figypt's land,

A poor man's son of Alexander's band.

Dioclesian, emperor, was a scrivener's son, And Probus from a gard'ner th' empire won. 


\section{EARLY PROSE AND POETICAL WORKS.}

Pertinax was a bondman's son, and won

The empire ; so did Valentinian,

Who was the offspring of a rope-maker,

And Maximinus of a mule-driver.

And if I on the truth do rightly glance,

Hugh Capet was a butcher, king of France.

By this I have digressed, I have expressed,

Promotion comes not from the east or west.

So much for that, now to my theme again.

This 'Thomas Parr hath liv'd th' expired reign

Of ten great kings and queens, th' eleventh now sways

The sceptre, blest by th' ancient of all days,

He hath surviv'd the Edwards, fourth and fifth,

And the third Richard, who made many a shift

To place the crown on his ambitious head.

The seventh and eighth brave Henries both are dead,

Sixth Edward, Mary, Philip, Elizabeth,

And blest remembered James, all these by death

Have changed life, and almost 'leven years since

The happy reign of Charles our gracious prince,

Tom Parr hath liv'd, as by record appears

Nine months, one hundred fifty, and two years.

Amongst the learn'd, 'tis held in general

That every seventh year's climaterical,

And dang'rous to man's life, and that they be

Most perilous at th' age of sixty three,

Which is, nine climactericals; but this man

Of whom I write, since first his life began,

Hath liv'd of climactericals such plenty,

That he hath almost out-lived two-and-twenty.

For by records, and true certificate,

From Shropshire late, relations doth relate,

That he liv'd 17 years with John his father,

And 18 with a master, which I gather

To be full thirty-five; his sire's decease

Left him four years possession of a lease;

Which past, Lewis Porter, gentleman, did then

For twenty-one years graut his lease again :

That lease expir'd, the son of Lewis called John,

Let him the like lease, and that time being gone, 
Then Hugh, the son of John, last nam'd before, For one and twenty years sold one lease more. And lastly, he hath held from John, Hugh's son, A lease for's life these fifty years, out-run : And till old Thomas Parr, to earth again Return, the last lease must his own remain. Thus having shew'd th' extention of his age, I'll shew some actions of his pilgrimage.

A tedious time a bachelor he tarried, Full eighty years of age before he married. His continence, to question I'll not call, Man's frailty's weak, and oft doth slip and fall. No doubt but he in four score years might find In Salop's county, females fair and kind. But what have I to do with that; let pass, At th' age aforesaid he first married was To Jane, John 'Taylor's daughter; and 'tis said, That she, before he had her, was a maid. With her he liv'd years three times ten and two, And then she died, as all good wives will do. She dead, he ten years did a widower stay; Then once more ventured in the wedlock way; And in affection to his first wife Jane, He took another of that name again; With whom he now doth live, she was a widow To one nam'd Anthony, and surnam'd Adda. She was, as by report it doth appear, Of Gilsells parish, in Mongom'ryshire, The daughter of John Lloyd, corruptly Flood, Of ancient house, and gentle Cambrian blood. But hold, I had forgot, in's first wife's time, He frailly, foully, fell into a crime, Which richer, poorer, older men and younger, More base, more noble, weaker men and stronger Have fallen into.

The Cytherean or the Paphoean game, That thundering Jupiter did oft inflame; Most cruel cut-throat Mars laid by his arms, And was a slave to love's enchanting charms, And many a pagan god and semi-god 
The common road of lustful love have trod; For from the emperor to the russet clown, All states, each sex, from cottage to the crown, Have in all ages since the first creation, Been foiled and overthrown with love's temptation. So was old Thomas, for he chanc'd to spy

A beauty, and love entered at his eye,

Whose pow'rful motion drew on sweet consent,

Consent drew action, action drew content;

But when the period of those joys were passed, Those sweet delights were sourly sauc'd at last.

The flesh retains what in the bone is bred, And one colt's tooth was then in cld Tom's head.

It may be he was gull'd as some have been, And suffered punishment for others' sin ; For pleasures like a trap, a grin, or snare, Or like a painted harlot, seems most fair, But when she goes away and takes her leave, No ugly beast so foul a shape can have. Fair Katherine Milton was this beauty bright, Fair like an angel, but in weight too light, Whose fervent feature did inflame so far 'The ardent fervour of old Thomas Parr, That for larw's satisfaction 'twas thought meet, He should be purg'd by standing in a sheet, Which aged he, one hundred and five year, In Alberbury's parish church did wear.

Should all that so offend such penance do, $\mathrm{Oh}$, what a price would linen rise unto;

All would be turn'd to sheets, our shirts and smocks, Our table linen, very porter's frocks

Would hardly 'scape transforming, but all's one, He suffered, and his punishment is done. But to proceed, more serious in relation,

$\mathrm{He}$ is a wonder worthy admiration; He's in these times fill'd with iniquity, No antiquary, but antiquity ;

For his longevity's of such extent, That he's a living mortal monument. And as high towers that seem the sky to shoulder, 
By eating time, consume away and moulder, Until at last in piece meal they do fall, Till they are buried in their ruins all.

So this old man, his limbs their strength have left, His teeth all gone, but one, his sight bereft, His sinews shrunk, his blood most chill and cold, Small solace, imperfections manifold. Yet still his sp'rits possess his mortal trunk, Nor are his senses in his ruins shrunk, But that his hearing's quick, his stomach good, He'll feed well, sleep well, well digest his food. He will speak heartily, laugh, and be merry; Drink ale, and now and then a cup a sherry; Loves company, and understanding talk, And, on both sides held up, will sometimes walk. And though old age his face with wrinkles fill, He hath been handsome, and is comely still, Well fac'd; and though his beard not oft corrected, Yet neat it grows, not like a beard neglected;

From head to heal, his body hath all over, A quick-set, thick-set nat'ral hairy cover. And thus, as my dull weak invention can, I have anatomiz'd this poor old man.

'Though age be incident to most transgressing, Yet time well spent, makes age to be a blessing. And if our studies would but deign to look, And seriously to ponder Nature's book, We there may read, that man, the noblest creature, By riot and excess doth murder nature.

'This man ne'er fed on dear compounded dishes, Of metamorphos'd beasts, fruits, fowls, and fishes, The earth, the air, the boundless ocean Were never rak'd nor forag'd for this man ; Nor ever did physician to, his cost, Send purging physic through his guts in post; In all his lifetime he was never known, That drinking others healths he lost his own; The Dutch, the French, the Greek, and Spanish grape, Upon his reason never made a rape;

For Ryot, is for Troy, an anagram; 
And Ryot, wasted Troy, with sword and flame. And surely that which will a kingdom spill, Hath much more power than one silly man to kill, Whilst sensuality the palate pleases, The body's filled with surfeits, and diseases. By riot, more than war, men slaughtered be, From which confusion this old man is free. He once was catched in the venereal sin, And, being punished, did experience win; That careful fear his conscience so did strike, He never would again attempt the like. Which to our understandings may express Men's days are shortened through lasciviousness, And that a competent contenting diet Makes men live long, and soundly sleep in quiet. Mistake me not, I speak not to debar Good fare of ail sorts ; for all creatures are Made for man's use, and may by man be us'd, Not by voracious gluttony abus'd. For he that dares to scandal or deprave Good house-keeping; oh, hang up such a knave; Rather commend, what is not to be found, Than injure that which makes the world renowned. Bounty hath got a spice of lethargy, And liberal noble hospitality

Lies in consumption, almost pin'd to death, And charity benumb'd near out of breath. May England's few good house-keeper's be blest With endless glory and eternal rest, And may their goods, lands, and their happy seed, With heav'ns best blessings multiply and breed. 'Tis madness to build high with stone and lime Great houses, that may seem the clouds to climb, With spacious halls, large galleries, brave rooms, Fit to receive a king, peers, squires, and grooms, Amongst which rooms the devil hath put a witch in, And made a small tobacco-box the kitchen; For covetousness the mint of mischief is, And Christian bounty the highway to bliss. To wear a farm in shoe-strings edged with gold, 
And spangled garters worth a copyhold;

A hose and doublet, which a lordship cost,

A gaudy cloak, three manor's price almost,

A beaver, band, and feather for the head,

Priz'd at the churches' tythe, the poor man's bread.

For which the wearers are fear'd and abhorr'd,

Like Jeroboam's golden calves ador'd.

- This double, treble, aged man, I wot,

Knows and remembers when these things were not.

Good wholesume labour was his exercise,

Down with the lamb, and with the lark would rise.

In mire and toiling sweat he spent the day,

And to his team he whistled time away.

The cock his night-clock, and till day was done,

His watch and chief sun-dial was the sun.

He was of old Pythagoras' opinion,

That green cheese was not wholesome, with an onion,

Coarse meslin bread, and for his daily swig,

Milk, butter-milk, and water, whey, and whig;

Sometimes metheglin, and by fortune happy,

He sometimes sipp'd a cup of ale most nappy,

Cider or perry, when he did repair

T'a a Whitsun ale, wake, wedding, or a fair,

Or when in Christmas time he was a guest

At his good landlord's house amongst the rest,

Else he had little leisure time to waste,

Or at the alehouse, huff-cap ale to taste.

Nor did he ever hunt a tavern fox,

Ne'er knew a coach, tobacco, or the pox;

His physic was good butter, which the soil

Of Salop yields, more sweet than Candy oil,

And garlick he esteemed above the rate

Of Venice treacle, or best mithridate.

$\mathrm{He}$ entertained no gout, no ache he felt,

The air was good and temperate where he dwelt,

Whilst mavisses and sweet-tongued nightingales

Did chant him roundelays and madrigals.

Thus living within bounds of nature's laws,

Of his long lasting life may be some cause. 
For though th' Almighty all man's days do measure, And doth dispose of life and death at pleasure, Yet nature being wrong'd, man's days and date May be abridg'd, and God may tolerate.

But had the father of this Thomas Parr, His grandfather, and his great-grandfather, Had their lives' threads so long a length been spun, They, by succession, might from sire to son Have been unwritten chronicles, and by Tradition shew 'Time's mutability.

Then Parr might say he heard his father well, Say that his grand-sire heard his father tell The death of famous Edward the Confessor, Harold, and William Conq'ror his successor; How his son Robert won Jerusalem, O'er-came the Saracens, and conquer'd them ; How Rufus reign'd, and's brother Heury next, And how usurping Stev'n this kingdom vex'd; How Maud the Empress, the first Henry's daughter, 'To gain her right fill'd England full of slaughter;

Of second Henry's Rosamond the fair, Of Richard Coeur-de-Lion, his brave heir King John, and of the foul suspicion Of Arthur's death, John's elder brother's son. Of the third Henry's long reign, sixty years, The barons wars, the loss of wrangling peers, How Long-shauks did the Scots and French convince, 'Tam'd Wales, and made his hapless son their prince. How second Edward was Carnarvon call'd, Beaten by Scots, and by his queen enthrall'd. How the third Edward, fifty years did reign, And t'honor'd Garter's Order did ordain. Next how the second Richard liv'd and died, And how fourth Henry's faction did divide 'The realin with civil, most uncivil, war 'Twixt long contending York and Lancaster. How the fifth Henry swayed, and how his son Sixth Henry a sad pilgrimage did run. Then of fourth Edward and fair Mistress Shore, King Edward's concubine, Lord Hasting's (- 


\section{THE VERY OLD MAN.}

Then how fifth Edward, murdered with a trick Of the third Richard; and then how that Dick Was by seventh Henry slain at Bosworth field; How he and's son th' eighth Henry, here did wield The sceptre; how sixth Edward sway'd, How Mary rul'd, and how that royal maid Elizabeth did govern, best of dames, And Phoenix-like expir'd, and how just James, Another Phonix, from her ashes claims The right of Britain's sceptre, as his own, But, changing for a better, left the crown Where now 'tis with king Charles, and may it be With him and his most blest posterity Till time shall end; be they on earth renown'd, And after with eternity be crown'd.

Thus had Parr had good breeding, without reading, He from his sire and grand sire's sire proceeding, By word of mouth might tell most famous things Done in the reigns of all those queens and kings. But he in husbandry hath been brought up, And ne'er did taste the Heliconian cup; He ne'er knew history, nor in mind did keep Ought but the price of corn, hay, kine, or sheep.

Day found him work, and night allowed him rest; Nor did affairs of state his brain molest, His highest ambition was a tree to lop, Or at the furthest to a May-pole's top; His recreation and his mirth's discourse Hath been the piper, and the hobby-horse. And in this simple sort he hath with pain, From childhood liv'd to be a child again. "Tis strange a man that is in years so grown Should not be rich; but to the world 'tis known, That he that's born in any land or nation, Under a twelvepence planet's denomination, By working of that planet's influence, Shall never live to be worth thirteen pence. Whereby, although his learning cannot show it, He's rich enough to be, like me, a poet.

But ere I do conclude, I will relate 


\section{EARLY PROSE AND POETICAL WORKS.}

Of reverend age's honourable state.

Where shall a young man good instructions have,

But from the ancient, from experience grave?

Rehoboam, son and heir to Solomon,

Rejecting ancient counsel, was undone

Almost; for ten of the twelve tribes fell

To Jeroboam, king of Israel.

And all wise princes and great potentates

Select and chose old men as magistrates,

Whose wisdom and whose reverend aspect,

Knows how and when to punish or protect.

The Patriarchs long lives before the flood,

Were given them, as 'tis rightly understood,

To store and multiply by procreations,

That people should inhabit and breed nations.

That th' ancients their prosperities might show,

The secrets deep of nature, how to know

To scale the sky with learned astronomy,

And found the ocean's deep profundity;

But chiefly how to serve and to obey

God, who did make them out of slime and clay.

Should men live now as long as they did then,

The earth could not sustain the breed of men.

Each man had many wives, which bigamy

Was such increase to their posterity,

That one old man might see before he died,

That his own only off-spring had supplied

And peopled kingdoms.

But now so brittle's the estate of man,

'That, in comparison, his life's a span.

Yet since the flood it may be proved plain,

That many did a longer life retain,

Than him I write of ; for Arphaxad liv'd

Four hundred thirty-eight, Shelah surviv'd

Four hundred thirty-three years, Eber more,

For he liv'd twice two hundred sixty-four.

Two hundred years Terah was alive, And Abr'ham liv'd one hundred seventy-five.

Before Job's troubles, holy writ relates,

His sons and daughters were at marriage states, 
And after his restoring, 'tis most clear, That he surviv'd one hundred forty-year. John Buttadeus, if report be true, Is his name that is styl'd, The Wandering Jew, 'Tis said, he saw our Saviour die; and how $\mathrm{He}$ was a man then, and is living now; Whereof relations you, that will, may read; But pardon me, 'tis no part of my creed. Upon a German's age, 'tis written thus, That one Johannes de Temporibus Was armour-bearer to brave Charlemagne, And that unto the age he did attain Of years three hundred sixty-one, and then Old John of Times return'd to earth again. And noble Nestor, at the siege of Troy, Had liv'd three hundred years both man and boy. Sir Walter Raleigh, a most learned knight, Doth of an Irish Countess, Desmond, write, Of seven score years of age, he with her spake. The Lord Saint Albanes doth more mention make That she was married in fourth Edward's reign, Thrice shed her teeth, which three times came again. The Highland Scots and the wild Irish are Long liv'd with labour hard and temperate fare. Amongst the barbarous Indians some live strong And lusty, near two bundred winters long? So as I said before, my verse now says, By wronging Nature, men cut off their days. Therefore, as times are, he I now write on, The age of all in Britain hath out gone; All those that were alive when he had birth, Are turn'd again unto their mother earth; If any of them live, and do reply, I will be sorry, and confess I lie. For had he been a merchant, then perhaps, Storms, thunderclaps, or fear of afterclaps, Sands, rocks, or roving pirates, gusts and storms, Had made him, long ere this, the food of worms. Had he a mercer or a silkman been, And trusted much in hope great gain to win, 


\section{EARLY PROSE AND POETICAL WORKS.}

And late and early strived to get or save, His grey head long ere now had been i'th grave.

Or had he been a judge or magistrate, Or of great counsel in affairs of state, 'Then day's important business, and night's cares Had long ere this interr'd his hoary hairs; But as I writ before, no care opprest him, Nor ever did affairs of state molest him. Some may object, that they will not believe His age to be so much, for none can give Account thereof, time being past so far, And at his birth there was no register. The register was ninety-seven years since Giv'n by th' eight Henry, that illustrious prince, Th' year fifteen hundred forty wanting twain, And in the thirtieth year of that king's reign; So old Parr now, was almost an old man, Near sixty ere the register began.

I have writ as much as reason can require, How times did pass, how leases did expire; And gentlemen o'th county did relate T'our gracious king by their certificate His age, and how time with grey hairs hath crowned him ;

And so I leave him older than I found him.

THE changes of manners, the variations of customs, the mutability of times, the shittings of fashions, the alterations of religions, the diversities of sects, and the intermixture of accidents which hath happened since the birth of this old Thomas Parr, in this kingdom; although all of them are not to be held worthy of mentioning, yet many of them are worthy to be had in memory.

In the sixth year of his age, and in the second year of the reign of King Henry the seventh, one Lambert Symnel, the son of a baker, claimed the crown, and was crowned King of Ireland, and proclaimed King of England in the city of Dublin. This paltry fellow did put the king to much cost and trouble, for he landed with an army at Fowdrey in Lancashire, and at a place called 


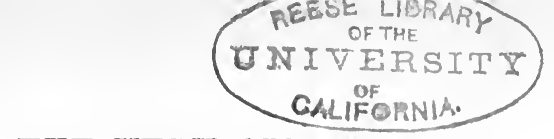

THE VERY OLD MAN.

Stoke the king met him, and after a sharp and short battle overcame and took him, and pardoning him his life gave him a turn-broaches place in the kitchen, and afterwards made him one of his falconers. Anno. 1487.

In the tenth year of his age, and the eighth of Henry the Seventh, another youngster, whose name was Perkin Warbeck, as some write, a tinker's son in Tournay, some say his father was a Jew; notwithstanding, he likewise put the king to much charge and trouble, for he was assisted with soldiers from Scotland and France; besides, many joined with him in England, till at the last the king took him, and on his true confession pardoned him, he falling again to his old practice was executed at Tyburn, 1499.

The same year also, a shoemaker's son, dwelling in Bishopsgate-street, likewise claimed the crown under the name of Edward, Earl of Warwick, the son of George, Duke of Clarence, brother to King Edward the Fourth; but this young shoemaker encied his claim in a halter at Saint Thomas a Waterings, which was a warning for him not to surpass $N e$ Sutor Ultra Crepidam.

Another counterfeit, the son of a miller, claimed the crown, in the second year of Queen Mary's reign, saying that he was King Edward the Sixth; but the tenth of May, 1552, those royal opinions were whipped out of him for a while, till be fell to his old claim again and purchased a hanging the thirteenth of March following. So much for impostures and counterfeits.

For religion, he hath known the times of divers sects and changes, as the Romish Catholic religion from his birth, till the twenty-fourth year of King Henry the Eighth, the time of fifty years; and the twenty-sixth of his reign, the king's understanding being illuminated from above, he cast the Pope's authority out of this kingdom, 1534, and restored the ancient and primitive religion, which continued under the title of Protestants till the end of his son, King Edward the Sixth, his reign, which was near about twenty years, then was a bloody alteration, or return to Papistry for more than five years, all the reign of Queen Mary; since whose death the Protestant religion 


\section{EARLY PROSE AND POETICAL WORKS.}

again was happily restored, continued and maintained by the defenders of the true, ancient, Catholic, and apostolic faith, these sixty-six years and more, under the blessed governments of Queen Elizabeth, King James, and King Charles. All which time Thomas Parr hath not been troubled in mind for either the building or throwing down of abbeys and religious houses; nor did he ever murmur at the manner of prayers, let them be Latin or English, he held it safest to be of the religion of the king or queen that were in being; for he knew that he came raw into the world, and accounted it no point of wisdom to be broiled out of it. His name was never questioned for affirming or denying the king's supremacy. He hath known the time when men were so mad as to kneel down and pray before a block, a stock, a stone, a picture, or a relic of a he or she saint departed; and he lived in a time when mad men would not bow their knee at the name of Jesus, that are more afraid to see a white surplice than to wear a white sheet, that despise the cross, in anything but money, that hold Latin to be the language of the beast, and hate it deadly because the Pope speaks it, that would patch up a religion with untempered morter out of their own brains, not grounded upon the true corner-stone, who are furnished with a lazy idle faith, that holds good works a main point of Popery, that hold their religion truest because it is contrary to all order and discipline both of church and commonwealth. These are sprung up since old Tom Parr was born.

But he hath out-lived many sectaries and heretics, for in the thirty-second year of the reign of King Henry the Eighth, 1540, the 3rd of May, three Ana-baptists were burnt in the highway between Sonthwark and Newington. In the fourth year of King Edward the Sixth, one George of Paris, a Dutchman, was burned in Smithfield, for being an Arian heretic, 1551. 1583, One John Lewis denied the Godhead of Christ, was burnt at Norwich, in the twenty-sixth year of Elizabeth. Not long before that, there was one Joan Butcher, alias, Joan of Kent, burnt for the like.

In the third year of Queen Elizabeth's reign, one 
William Geffrey affirmed one John Moore to be Christ, but they were both whipped out of that presumptous opinion, 1561.

In the seventeenth of Queen Elizabeth, the sect of the family of Love began 1575, but it took no deep root.

In the twenty-first of Queen Elizabeth, one Matthew Harmont was burned at Norwich for denying Christ to be our Saviour.

In the thirty-third of Queen Elizabeth, one William Hacket was hanged for professing himself to be Christ, 1591.

In the ninth year of King James, the 11th of April, 1611, one Edward Wightman was burned at Litchfield for Arianism.

So much have I written concerning sects and heresies which have been in this kingdom in his time, now I treat of some other passages.

He hath out-lived six great plagues. $\mathrm{He}$ was born long before we had much use of printing; for it was brought into this kingdom, 1472, and it was long after ere it was in use.

He was above eighty years old before any guns were made in England, 1535 .

The vintners sold no sacks, muscadels, malmseys, bastards, allegants, nor any other wines but white and claret, till the thirty-third year of King Henry the Eighth, 1543, and then was old Parr sixty years of age. All those sweet wines were sold till that time at the apothecaries for no other use but for medicines.

There was no starch used in England. A Flander's woman, one Mistress Dinghen Vandein Plasse brought in the use of starch, 1564 ; and then was this man near eighty years old.

There were no bands worn till King Henry the Eight's time, for he was the first king that ever wore a band in England, 1513.

Women's masques, busks, muffs, fans, periwigs, and bodkins, were invented by Italian courtezans, and transported through France into England, in the ninth of Queen Elizabeth. 


\section{EARLY PROSE AND POETICAL IVORKS.}

Tobacco was first brought into England by Sir John Hawkins, 1565, but it was first brought into use by Sir Walter Raleigh many years after.

He was 81 years old before there was any coach in England, for the first that ever was seen here was brought out of the Netherlands by one William Boonen, a Dutchman, who gave a coach to Queen Elizabeth, for she had been seven years a queen before she had any coach, since when they have increased with a mischief, and ruined all the best house-keeping, to the undoing of the watermen, by the multitudes of hackney or hired coaches; but they never swarmed so thick to pester the streets as they do now, till the year 1605, and then was the Gunpowder Treason hatched, and at that time did the coaches breed and multiply.

He hath out-lived the fashion at least 40 times over and over.

He hath known many changes of scarcity, or dearth, and plenty; but I speak only of the plenty.

In the year 1499, the fifteenth of Henry VII., wheat was sold for $4 \mathrm{~s}$. the quarter, or $6 \mathrm{~d}$. the bushel, and bay salt at $4 \mathrm{~d}$., and wine at 40 shillings the tun, which is about three farthings the quart.

In the first of Queen Mary, beer was sold for sixpence the barrel, the cask and all, and three great loaves for one penny.

In the year 1557, the fifth of Queen Mary, the penny wheaten loaf was in weight 56 ounces, and many places people would change a bushel of corn for a pound of candles.

So much shall suffice for the declaring of some changes and alterations that have happened in his time.

Now for a memorial of his name I'll give a little touch. I will not search for the antiquity of the name of Parr, but I find it to be an honourable name in the 12 th year of King Edward the Fourth. The king sent Sir IVilliam Parr, knight, to seize upon the Archbishop of York's goods at a place called the Moor in Hartfordshire, 1472. This Sir William Parr was knight of the right honourable Order of the Garter. 
In the twenty-second of Edward the Fourth, the same Sir William Parr went with an army. towards Scotland, with Richard, Duke of Gloucester.

In the year 1543, the thirty-fifth year of King Henry the Eighth, July 22nd, the king, was married to Lady Katherine Parr; and the 24th of December following, the queen's brother, William Lord Parr, was created Earl of Essex, and Sir William Parr, their uncle, was made Lord Parr of Horton, and Chamberlain to the queen; and the first of King Edward the Sixth, William Parr, Earl of Essex, was created Marquis of Northampton ; and in the 4th year of King Edward's reign, 1550, the said marquis was made Lord Great Chamberlain of England; and on the last of April, 1552, he, amongst other lords, mustered 100 brave, well-appointed horsemen of his own charge, before King Edward in the Park at Greenwich, his cognisance or crest being the maidenhead; in the first of Queen Mary, he took part with the Lady Jane against the queen, for which he was taken and committed to the Tower, July 26th, and, contrary to expectation, released again shortly after, March 24 th.

Also, the first of Queen Elizabeth, William Parr, Marquis of Northampton, sat in Westminster Hall, Lord High Steward, upon a trial of William Lord Wentworth, who had been late Lord Deputy of Calais, which noble Lord Wentworth came off most honourably acquitted, April 22 nd.

After the death of King Henry the Eighth, Queen Katherine Parr was married to Sir Thomas Seymour, Lord High Admiral, and she died the 2nd of September, 1548.

And thus I lay down the pen, leaving it to whomsoever can or will make more of this old man than I have done. 
PART OF THIS SUMMER'S TRAVELS:

or

NEWS FROM

\section{HELL, HULL, AND HALIFAX,}

FROM

YORK, LINNE, LEICESTER, CHESTER,

COVENTRY, LICHFIELD,

NOTTINGHAM,

Eтc.,

With many pleasant passages worthy your observation and reading. 


\section{A FEW WORDS OF DIRECTION TO THE READER.}

I HAVE not written every place in that order as is set down in the title of this pamphlet, but of such places as I travelled unto, I have truly related the passages, and the time, both when, where, why, and how I went, came and performed it. If any man ask wherefore this book is good, or how it may be any way useful, I answer that it is four ways commodious. First, it is profitable, for it will direct a man the high-ways of crossing divers countries from place to place, which no other book shows, as from Leicester to Lynn in Norfolk, from Lynn to Kingston upon Hull in Yorkshire, from Hull to York, thence to Halifax, to Chester, Derby, Nottingham, Coventry, Lichfield, and the Devil's Arse a Peak; all these ways are herein described. Secondly, there are some monuments of antiquity are mentioned, which greater authors have omitted. Thirdly, there are some passages of delightful mirth and recreation. And lastly, all is true, or else you have the author's leave to travel as he hath done, and do your best and worst to prove him a liar. 


\section{PASSAGES AND ENTERTAINMENTS FROM LON- DON 'TO LEICESTER, WITH SOME OBSERVA- TIONS OF THE SAID TOWN AND SHIRE.}

Upon Saint Swithin's day, I noted well, The wiud was calm, nor any rain then fell; Which fair day, as old saws saith, doth portend, That heav'n to earth will plenteous harvest send. The morrow being July's sixteenth day, In my progression I began my way. I need not to relate the towns that lie Just in my way, as I rode through or by, Only at Mims, a cockney boasting braggart In mirth. did ask the women for Belswagger, But straight the females like the furies fell, Did curse, scold, rail, cast dirt, and stones pell mell ; But we betook us nimbly to our spurs, And left them calling us rogues, knaves, and curs; With other pretty names, which I discerned They from their old fore-mother's well had learn'd. The reason why they are with rage inflam'd, When as they hear Belswagger nam'd, Is, as report doth say, there dwelt a squire, Who was so full of love, or lust's desire, That with his fair tongue, hypocritic-hood, By slanderous people 'twas misunderstood, The women were so fruitful, that they were All got with child, in compass of one year, And that squire's name, they say; Belswagger was, And from that tale, the lying jeer doth pass, Wherefore the women there will chide and swagger, If any man do ask them for Belswagger. Thence passed I on my journey unto Hockley, Where as I saw a drunkard like a block lie, There I alighted at the sanguine Lion, Where I had meat, drink, and a bed to lie on; The next I rode stately to Northampton, And all the way my horse most proudly stamped on. On Thursday, trotting, galloping and ambling, To Leicester I proceeded in my rambling; 


\section{EARLY PROSE AND POETICAL WORKS.}

There, at the Blue Boar I was welcome than

Unto my brother Niles, a downright man,

Plain dealing, free from flattery, fraud or fear,

Who hath lived long with reputation there;

He's old and honest, valiant, courteous, free.

I write not this for making much of me,

But they that doubts on't, let them go and try,

And if he be a changling, say I lie.

That house King Richard lodged in, his last night,

Before he did the field of Bosworth fight,

And there's a room, a king to entertain,

The like is not in Leicester town again.

The Assizes then were there, some causes tried,

And law did there the corpse and souls divide,

Of two offenders, one had with a knife

Stabbed his contracted love, and revealed her life,

T'other, a wench that had stolen some poor raiment,

And fired the house, deserved the hangman's payment.

King Lear a temple did to Janus rear,

And placed a flamine in't, there doth appear

The arched ovens four yards thick at least,

Wherein the heathen sacrifices drest;

Like as the Jews in their idolatry,

Offered their sons and daughters impiously,

To Moloch, Nisroch, Ashtaroth, and Baal ;

And to those devilish gods adore and fall,

So people here, when war or peace they sought,

'They offerings unto Janus' Temple brought.

This was eight hundred forty and four year

Before our Saviour's birth, built by King Lear,

Long after Ethelred, the Mexican king,

A happy and a Christian change did bring,

The temple raz'd, the flamine he defac'd,

And there a Christian bishop's see he placed,

Which last but few years, for then this land

Was seven-fold yoked, beneath se en kings command,

And those kings still were in perpetual wars

That England was quite spoiled with endless jars,

And in those garboiles Leister had her share,

Spoiled, rifled, ransacked, robbed, and left most bare, 
Till Ethelred, with great magnificence, Repaired and walled it strongly for defence. Then did it flourish long in wealth and state, Till second Henry it did ruinate.

$\mathrm{He}$ in outrageous fury fired the town,

Diswalled it quite, and cast the castle down,

So nothing but some ruins doth appear,

Whereby men may perceive that such things were.

Thus Leister fell, from state superlative,

Her fifty churches all consumed to five.

Yet it is fair and spacious at this day,

And East, West, North and South 'tis every way

Above a mile in length, so that no doubt,

The town's in circuit six large miles about.

Henry first Duke of Lancaster in war,

In peace, or bounty a bright blazing star

For buildings in this city is renowned,

Which as time rais'd, time did again confound.

Yet one large fabric there doth still abide,

Whereby the good Duke's name is dignified.

And that's an hospital or bead-house, where

One hundred and ten men are harbour'd there,

From perishing through want, still to defend

Those aged men until the world shall end.

Twice every day a chaplain doth repair

To them; and unto Grod sends praise and prayer,

And nurses are allow'd to dress their meat,

To make their beds, to wash, and keep them neat;

For which they thankful be to God alone,

Who raised such means to ease the poor man's mone.

Good Henry Earl of Huntingdon, renown'd,

A free school did erect there, from the ground,

With means, though mean, for maintenance endowed

Two ushers and one schoolmaster allowed,

They teach young lads, such rules as do belong,

To read the English and the Latin tongue,

And when their knowledge is with hope discerned,

They in the Greek may learn, and be more learn'd.

But to relate something in prose of this ancient town of Leicester, in the time of nine weeks, which I abode 


\section{EARLY PROSE AND POETICAL WORKS.}

there to and fro, I observed such a civil government and decency which is not in many places to be found or equalized.

First, I noted the peace, tranquility, and unity which the people live in, under the rule and command of the mayor and his brethren, to whose autbority and power, under the king, the inhabitants do willingly obey.

Secondly, the clergy or ministry, are learned, diligent, and painful; and both clergy and laity, are conformable to the orders and discipline of the Church of England, and I did not hear of any one, residing there, that is either schismatically opinionated with dogmatical whimseys, or Amsterdamnable fopperies.

Thirdly, they are so charitable and careful in providing for the relief of the poor and needy, that a man must go seek where to bestow his alms, for there is not any one, that I could see, that begged in the whole town.

Fourthly, the streets are so well paved, and kept so clean from dunghills, filth, or soil, that in the wettest and foulest weather, a man may go all over the town in a pair of slippers, and never wet his feet.

Lastly, the people are generally so loving one to another, that the lawyers want work, and so honest that the apparitors are idle, and those few drunkards which they have are very civil and fair conditioned.

\section{Certain other observations.}

There is a fair library, and a well founded alms-house within the town, also two gaols, two houses of correction, and for mad and fiantic people. Also it is reported, that when King Richard the Third went from Leicester, to fight the battle near Bosworth, that then there was a man of mean calling, some say he was a weaver, and some say a ploughwright by his trade, he had a spirit of divination or prophecy, of whom the tyrant King Richard demanded some questions what the event of that day's fight might be to him, to whom the other most bluntly answered, "Mark my words King Richard, that as thou dost ride out of the town of Leicester this morning, thou shalt hit thy right foot agaiust a stone, and as thou returnest thou shalt 
knock thy head against the same," which proved true, for as he rode, he did strike against the corner of $a_{c}$ wall his foot, and after he was slain in the field, he was stripped, and his body laid across behind a man on horseback, like a calf, and in that vile and ignominious manner, as they brought his corpse back to Leicester, his head did knock against the aforesaid wall or stone, which place I saw there; also I went eight miles to see Redmore field, where the king fell, which is a moorish kind of ground, altogether unfruitful, and the water doth seem red, which some foolish people do suppose to be the stain of KingRichard's blood, but it is only the colour of the red earth that makes the water seem so, and the ground close adjoining is very fertile for corn and pasturage, but in the lower parts it is boggy and moory by nature, and not either barren or bloody by any reasons of the king's death.

Another observation is concerning the alteration of the measures of miles, and good sufficient pots or jugs of drink, but the further I travelled northward, the more the miles were lengthened and the pots shrunk and curtailed; but indeed, what the liquor wanted in measure it had in strength, the power of it being of such potency that it would fox a dry traveller before he had half quenched his thirst.

In this county of Leicester I observed a piece of extreme justice executed upon three geese, which was thus.

At a village called Dadlington, eight miles from Leicester, there dwells a gentlewoman, a kinswoman of mine, who the last trinity term, 1639, was at London about some business in law which much concerned her; and in her absence the Pinder of Dadlington, finding three of her geese innocently grazing upon the common, for to show the full power, force, virtue, and marrow of his office and authority, drave the geese in the pound or pindfold, and because they could procure no bail for their release, nor sureties for their true imprisonment, he put all their three necks into a horselock, which engine and neck-fetter was so straight, close, and pinching, that the 
geese were all strangled. Now the question is whether Willy 'Tilly, the pinder so silly, were the cause of their deaths, or whether the geese did desperately cast away themselves; all which I humbly refer to the discretion of the jury.

But some readers may muse why $\mathrm{I}$ do write so much of Leicester in this little book. The reason is that I lay there from the 17th of July to the 20th of August, which was five weeks; but in the mean space I rode to Coventry and returned in a day to Leicester again. Of Coventry I have little to say but that it is a fair, famous, sweet, and ancient city, so walled about with such strength and neatness, as no city in England may compare with it. In the walls, at several places, are 13 gates and posterns whereby to enter and issue too and from the city; and on the walls are 18 strong defensible towers, which do also beautify it. In the city is a fair and delicate cross, which is for structure, beauty, and workmanship, by many men accounted unmatchable in this kingdom; although myself with some others, do supppose that of Abingdon in Berkshire will match it, and I am sure the cross in Cheapside at London doth far out-pass it. I have been at this city four times, and have written on it before, and therefore at this time, my stay being so short there, I have but little to say; only this that some are of opinion that at the first it was called Coventry, from the French word Trey Covent, because there were founded three convents for three several Orders of Friars, namely, the Franciscan Friars, the Augustine Friars, and the Dominicans. It matters not much who erected the said foundations and convents, but it is certain that the renowned King Henry the Eighth did suppress and demolish them, whose memories now is almost quite buried in their own ruins. Coventry is a county of itself; it hath been graced and dignified much by the grants and privileges given to it by former kings, as King Edward the Third and King Henry the Sixth; the mayor's name, at my being there, was Master Thomas Forrest, a vintner, and Master Thomas Phineas, sword-bearer there, died at the beginning of the sessions, much about the time of 
my being there, he was a man of that comely bulk and corpulency, that his coffin was a full yard wide at the shoulders, and it is said, that in his life time he could have been, at one meal, the consumption of a large shoulder of mutton; but he and his good stomach being both deceased, I left Coventry because it was sessions time, and returned to my rendezvous at Leicester.

The eleventh day of August I rode from Leicester to Nottingham, where I lodged at the sign of the Princes Arms; but I was well entertained at the house of the Right Worshipful Sir Thomas Hutchinson, Knight, himself and his good lady made me welcome, and did express their bounty to me in good cheer and money, for the which I'am heartily thankful.

The town of Nottingham is seated on a hill, which hill is almost of one stony rock, or a soft kind of penetrable sandy stone. It hath very fair buildings, many large streets, and a spacious market place. A great number of inhabitants, especially the poorer sort, do dwell in vaults, holes, or caves, which are cut and digged out of or within the rock; so that if a man be destitute of a house, it is but to go to Nottingham, and with a mattock, a shovel, a crow of iron, a chizel, a mallet, and such instruments, he may play the mole, the coney, or the pioneer, and work himself a hole, or a burrow, for him and his family, where over their heads the grass and pasture grows, and beasts do feed; fair orchards and gardens are their coverings, and cows are milked upon the tops of their houses. I was much befriended by Master Palmer the jailor there, for he went with me and showed me the (sometimes) strong and defencible castle, but now much ruined. Yet still there are many fair and sumptuous rooms in reasonable reparation and estate. On the lofty battlements of the said castle, there is a most spacious prospect round about, for from thence I could see the most stately Castle of Belvoyre or Bever Castle, which doth, as it self, belong to the right honourable the Earl of Rutland; and nearer hand, within three miles, I saw the ancient town of Gotham, famous for the seven sages, 


\section{EARLY PROSE AND POETICAL WORKS.}

or wise men, who are fabulously reported to live there in former ages.

In the aforesaid Castle of Nottingham, I was showed divers strange, wonderful vaults, cut or hewn out of the rock, whereof one is said to be the place where David, King of Scots, was detained many years in captivity, where the said king, with his own hands, without any other instrument than the nails of his fingers, did with the said tools engrave and claw out the form of our Saviour's life, death, and passion, which work is there to be seen upon the walls.

Also there is another vault or passage through the rock, whereby men may descend or ascend out or into the castle ; which vault is called Mortimer's Hole, through which hole, as report goes, the great Roger Mortimer, Earl of Wigmore, and Lord of Wallingford, had egress and regress to the queen, wife to King Edward the Second, or the unfortunate Edward of Carnarvon.

Thus having seen as much of Nottingham town and castle as is related, on the twelfth of August I rode to the ancient town of Derby. On the thirteenth of August I left Derby with an intent to retire to Leicester, but after I had rode half a mile, I met with an acquaintance of mine who was travelling towards the Peak in Derbyshire, to a town called Wirksworth, and from thence to Chesterfield I returned with him. The country is very mountainous, and many lead mines are found thereabouts. The best and most richest is called Dove Gany, within a mile or little more of Wirksworth, corruptly called Wortsworth, and two miles from thence are most dangerous ways, stony, craggy, with inaccessible hills and mountains. The grounds there are lawful, as they told me, for any man to dig or mine in for lead, be they of what condition soever; for the laws of mining is, that those that will adventure their labours shall have all the profits, paying the tenth part to the lord or landlord of all the lead which they get. If it happen that they take pains, a year or two in sundry places to find a mine if their fortune be so hard to find none, as it often falls out so, they do work all that while for nothing, and find themselves 
as they are able, and in the end their toil and labour is all lost: but if they do hit upon a good mine that doth hold out and yield plentifully, then they may quickly enrich themselves, if they be good husbands. I was told of a poor thatcher that left his trade, and venturing his time and pains, he found so rich a lead mine that he would turn a gentleman, and he kept men in liveries, living at the rate of the expense of 100 pounds a week; so that he supposing that leaden, golden world would never be ended, took no care to save anything; but after a while the mine failed, and he spent that little which he had left in digging for more, could find none, so that for a conclusion, he forsook the Peak, and turned thatcher again.

That part of the Peak which is called the Devil's Arse, is at or near a town named Castleton, or Castle Town, so styled from an ancient ruined castle on a hill at the end of the town. It is 30 miles from Derby ; the castle stands at the top of a hill, and under it is a cliff' or riff in the said hill, which is as wide at the entrance as three barn doors, but being entered in it is enclosed again so narrow, that a man must stoop to pass further; but after that straight passage is past, there is rooms of incredible and wonderful greatness, with strange and intricate turnings and windings, which no man can see without great store of lights, and by reason that those things are natural, and formed without any art or labour of man, and withall so dismal, horrid, dark, and hideous, that place is called the Devil's Arse a Peak, at or upon which I have, according to my promise, given three jerks with my pen, at the latter end of this book.

From thence I returned towards Leicester, 30 miles, on the 15th of August, and lodged at a market town called Narbury, and the next day I came all tired and weary, both man and beast to Leicester, and on the 20th day, I took my journey 64 miles into Norfolk, to the famous town of Lynn, and three miles from thence, at a village called Wooton, I was there well welcomed by Master Richard Miles, to whom I am and must be thankful brother in law, whose loving kindness to me was showed 


\section{EARLY PROSE AND POETICAL WORKS.}

in such extraordinary manner, which because I cannot express, I will remain grateful with silence.

Concerning Lynn, it is an excellent sea-town and strong port, it is gravely and peaceably governed by a mayor, 12 aldermen, and a recorder. It hath been honoured by divers, but chiefly by King John 440 years since, and by King Henry the Third. The first gave them a fair gilt cup, which is there to be seen as a witness of his royal liberality; and who so will know more of Lynn, let them go thither and look the records of the town, or else let them read Master Camden's "Britannia," or the painful labours of Master John Speed. The truth is, mine host noble was a noble host to me, at whose house my brothers, kindred, and friends, gave me a friendly farewell. On Tuesday the 27th of August, from Lynn to Boston in Lincolnshire, twenty-four miles, where I dined with the right worshipful Sir Anthony Thomas Knight; from Boston I rode fourteen miles to Horn Castle, where I lodged the 28th of August. But I crave pardon of the reader, for I had almost forgotten a merry passage or two which happened in Norfolk, not far from Lynn; and thus it was.

At a place called Priors Thorns, near two towns, namely, Northbury and Sapham, there dwelt a man named Friar, who was rich in substance but very poor and miserable in his conditions; belike he had read or heard of a play that was written forty years since by Master Benjamin Jonson, the play is extant, and is called "Every man out of his Humour," in which play was acted and personated a miserly farmer, that had much corn in his barns, and did expect a scant or barren harvest, that through want and scarcity he might sell his corn at what dear rates he pleased; but, contrary to his wicked hopes, the harvest proved abundantly plentiful, wherefore he being in an extraordinary merry or mad vein, put himself to the charge of the buying a twopenny halter, and went into his barn as secretly as he could, and putting the halter about his neck with a riding knot, he fastened the other end to a beam, and most neatly hanged himself. But, as ill luck would have it, his man presently came into the 
barn, and espied his master so bravely mounted, the unlucky knave drew his knife and cut the halter, crying out for help as loud as he could, rubbing and chafing his master with all care and diligence to recover him to life again. At the last he awakened out of his trance and fetched a deep groan, began to stare and look about him; and taking the end of the cut halter in his hand, his first words to his man was, "Sirrah, who did cut this?" "O master," said the fellow, " it was I that did it, and I thank God that I came in good time to do it, and I pray you to take God in your mind, and never more to hazard your soul and body in such a wicked manner ;" to which good counsel of the poor fellow, the caitiff replied, "Sirrah, if you would be meddling, like a saucy busy rogue, you might have untied it, that it might have served another time; such an unthrifty rascal as thou will never be worth such a halter. It cost me twopence, and I will abate the price of it in thy quarter's wages." And when the quarter day came, he did abate the said twopence, for the which the fellow would dwell no longer with him, but went and got him another service. 'This was acted really and lately at the place aforesaid, in imitation of that part in the play of "Every man out of his Humour."

After the said Friar had some hogs which were like to die of the murrain, which hogs he killed and powdered, and his wife, children, and family, as many as did eat of the pork, fell sick and died all; for the which the slave deserved a hanging and a hangman, but he yet lives for some worse purpose.

Concerning a pair of brewers, and a piece of justice. Another short Norfolk tale is not impertinent. 'There was one Master Fen, a brewer at Fensham; and one Master Francis Dix, a brewer at Sapham. This Dix was riding in the country amongst his customers, the innkeepers and victuallers, and he called for a pot of ale or beer as he rode by. Now that ale-house was a customer to Fen, as soon as Dix had drank he asked who brewed that drink, to whom the hostess said that Master Fen of Fensham brewed it. "Well," said Dix, "I dare lay a wager, that I will give my mare but a peck of malt, and 


\section{EARLY PROSE AND POETICAL WORKS.}

she shall piss better drink than this;" at the last these words came to Fen's hearing, for the which disparagement he sued Dix, and recovered from him twenty pound damage, besides cost, at the Assizes last at Norwich, 1639. And now to return to the narration of my travels, from whence I have digressed since I lodged at Horn Castle in Lincolnshire.

From thence, on the 18th of August, I rode 30 miles to Barton-upon-Humber, and the next day, being Friday, I took a boat for inyself, my squire, and my two palfreys, down to Hull, or Kingston-upon-Hull, the strength and situation of which town I have formerly written of ; and I had no new thing there whereof to make any new relation. Let it suffice that it is absolutely accounted the strongest and most defensible town in the kingdom of England, and for good government inferior to none. I might speak somewhat of their good fellowship, but my - book would swell big with it, therefore I will pay them with thinking and thanking of them, both my old friends and new acquaintance all in general.

The 3ist of August I left Hull, and rode to Holden, 16 miles, and on the morrow I rode to Cowood Castle, to see the most Reverend Doctor Neale, the Lord Archbishop of York his Grace, whom in all humility I do acknowledge inyself much bound in duty daily to pray for, and remember him with unfeigned reverend thankfulness, not only for the undeserved favours and bounty which his Grace extended towards me now, but for many other former approvements of his Grace's love and liberality, when his Grace lived near me at Winchester House. At dinner with his Grace, I had the happiness to renew my acquaintance with the noble and worthy Knight Sir Francis Wortley, who most courteously invited and commanded me to visit him in my journey, of which more followeth.

My humble thanks remembered to the right worthy worshipful Knight Sir Paul Neale, with his fair and virtuous lady, as also my grateful remembrance to all my lord's gentlemen and servants, to whose loves and for 
whose friendships I shall ever acknowledge myself an engaged debtor.

Thus having passed the Sunday with my Lord's Grace, and those other before named gentlemen, on Monday the second of September, I took my breakfast and my leave both of Cowood, and rode to York, where I visited the worthy Knight, my old acquaintance, Sir Arthur Ingram, with whom I thank his worship, I dined, and also had some other token of his love and bounty, for the which I remain thankful.

Of York I have but little to say, though it be a great, a fair, and the second city in England, built 989 years before our Saviour's birth, by Ebranc King of this land, from whom the city is called Eboracensis. This Ebranc is said to have 21 wives, by whom he had twenty sons, and 70 [sic] daughters. He reigned here when as King Solomon reigried in Jerusalem, he overran France, he builded Alclaid, or Dumbritton in Scotland, he founded York, he erected a temple there, and therein placed a flamine to Diana ; but after, in King Lucius' time, Elutherius pull'd down the said idolatrous wooden temple, and displaced the flamine, and caused the minster to be built in that magnificent manner of free stone, placing there an Archbishop. Severus the Roman Emperor died there, and also there died the Emperor Flavius Valerius Constantius, which some call Chlorus. Those that will know more of York, let them read chronicles and larger volumes.

The Lord Mayor of York was, at my being there, one Sir Roger Jacques, knight, a gentleman of approved wisdom and government. Myself did not stay three hours, and mine host Master Corney at the Talbot, told me all the news which I heard there, which was a fellow, that, amongst other offenders, was the first that was hanged and the last that was cut down, and being put into the grave or pit with his fellows, when the earth was cast upon them he began to stir and recover life and was returned to the gaol, is now there living and able to report truly what hanging is. Probatum est.

From York I rode after dinner to Tadcaster, and so to a place called Kidell, where at a poor ale-house I was

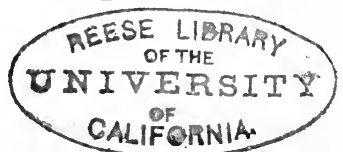




\section{EARLY PROSE AND POETICAL WORKS.}

glad of entertainment, and had the company of a tinker who made pretty music with his Banbury kettle-drum. There was also with him two drovers and 35 hogs, which were to be driven on the morrow seven miles further to Leeds market. 'This good lodging and company I passed the night withal, and on the morrow I rode to the town of Leeds, of which town I must say somewhat. This town is, for the bigness of it, one of the most populous towns in England; it bath in it 12,000 people, and having but one church there, it was not half capable to receive so great a congregation. They were extremely thronged and dangerously crowded, especially in the heat of summer, or sultry contagious weather, that the most part of the people were enforced either to go two or three miles several ways to other village churches, or else to stay at home and want the hearing of God's word, and the means of their salvation. The care and consideration of these grievances entered into the pious mind of one Master John Harrison, gentleman there, now living, so that God opened his heart, that of his own proper costs.he caused a church to be built, though it have but the name of a chapel, which is so large that it will contain 4000 people. It is so neatly compacted and framed with exquisite art of carving and masonry, with painting, gilding, polishing, embellishing, and adorning, with a most stately roof, a fair lofty tower or steeple, a sweet ring of bells; besides the admirable and costly joiners and carvers workmanship in the font, pulpit pews, chancel, communion-board, and all other things and ornaments for the decent adornment of such a house consecrated and dedicated to the service of God. I do absolutely affirm that neither the church or the founder hath any fellows to be found.

This chapel is called by the name of Saint John Evangelist, it hath a fair churchyard for burials, well and strongly walled about, and at the west end of the churchyard the said gentleman hath founded a fair alms-house, and therein placed 21 poor aged people; also he hath founded and finished a fair school house for the instruction of youth, and a fine sweet street he hath built on both sides in a uniform and fair manner with houses, the 
rents whereof are for the maintenance of the alms-houses, the school, and reparations of the church to the end of the world. And I leave this worthy founder to God for a blessing and to the world for imitation.

From Leeds I went to Wakefield, where if the valiant Pindar had been living, I would have played Don Quixote's part and challenged him; but being it was so happy that he was dead, I passed the town in peace to Barnsley, and so to Wortley, to Sir Francis. Wortley's ancient house. The entertainment which himself, his good lady, and his most fair and hopeful daughter gave me there, as I never did or can 'deserve, so I never shall be able to requite, to talk of meat, drink, money, and free welcome for horse and man, it were but a mere foolery for me to begin, because then I should run myself into a labyrinth, out of which I should hardly find the way. Therefore to his worship, my humble thanks remembered, and everlasting happiness wished both to him and all that is his. Yet I cannot forbear to write a little of the further favour of this noble knight. Upon the fourteenth of September afternoon, he took horse with me, and his lady and daughter in their coach, with some other servants on horseback; where three miles we rode over rocks and cloud-kissing mountains, one of them is so high that, in a clear day, a man may from the top thereof see both the minsters or cathedral churches, York and Lincoln, near 60 miles off us; and as it is to be supposed that when the devil looked over Lincoln, as the proverb is, that he stood upon the mountain or near it. Sir Francis brought me to a lodge, the place is called Wharncliff, where the keeper dwells, who is his man, and keeps all this woody, rocky, stony, vast wilderness under him, for there are many deer there, and the keeper were an ass if he would want venison having so good a master.

Close to the said lodge, is a stone in burthen at the least 100 cart loads, the top of it is four square, by nature, and about twelve yards compass; it hath three seats in the form of chairs made by art, as it were in the front of the rock, wherein three persons may easily sit and have a view and goodly prospect over large woods, towns, corn- 


\section{EARLY PROSE AND POETICAL WORKS.}

fields, fruitful and pleasant pastures, valleys, rivers, deer, neat, sheep, and all things needful for the life of man; contained in thousands of acres and all, or the better part, belonging to that noble knight's ancestors and himself. Behind the stone is a large inscription engraven, where in an old character is described the ancient memory of the Wortley's, the progenitors to Sir Francis now living, for some bundreds of years, who were lords and owners of the said lands and demains which he now holds as their righ their. About a bow shot from thence, by the descent of many rungs of a ladder, his worship brought me to a cave or vault in the rock, wherein was a table with seats and turf cushions round, and in a hole in the same rock was three barrels of nappy liquor. Thither the keeper brought a good red deer pie, cold roast mutton, and an excellent shoeing-horn of hanged Martinmas beef; which cheer no man living would think such a place could afford. So after some merry passages and repast we returned home.

On the $5 \mathrm{fth}$ of September, I hired a guide, and rode to Halifax 16 miles; the ways were so rocky, stony, boggy and mountainous, that it was a day's journey to ride so short a way. At Halifax I saw the fatal engine, wherewith they do behead pilfering thieves, which Sir Francis Wortley told me was set upon this occasion following :-

This town of Halifax hath, for time out of mind, lived and subsisted by the rich and laudable trade of clothing, and often times their clothes were stolen from the tenterhooks, or tenters, whereupon the king, then reigning, upon their humble suit had privileg*e granted to the town for ever: That if a thief were taken either of these three ways, which is, hand-napping, back-bearing, or tongueletting, that is either about to steal, or carrying it away, or confessing, that then the party offending, after trial by a jury of townsmen, if the goods, be it cloth, cattle, or whatsoever is valuable, is judged to have their heads struck off with the said engine, without any assize or sessions. Now the engine is two high pieces of timber, an ell or yard asunder, fixed and closed on the top, with a cross piece like a gallows; in the inner sides of the two 
standing pieces are two gutters, and on the top, or cross piece, is a pully through which they do put a small line or rope, and fastening it to another heavier piece of wood of 100 weight, in which they do fix the sharp-edge tool, then they do pull or hoist up the said weight, and the stolen goods is brought to the place of execution with the malefactor. Now the one end of the rope is made fast to a pin or stake, which being cut, the engine falls so ponderously and speedily, that it severs the head from the body in a moment; but there is no man will or must cut the line, but the owner of the stolen goods, which if he do, he hath all again. If he will not cut it, then he must lose all, and it is employed to some charitable uses; by which means the thief escapes; and this is Halifax law.

The sixth day I left Halifax, and rode over such ways as are past comparison or amending, for when I went down the lofty mountain called Blackstone Edge, I thought inyself with my boy and horses had been in the land of Breakneck, it was so steep and tedious, yet I recovered 12 miles to Rochdale, and then I found smooth way to Manchester, and to Sandy Lane end 13 miles; and to Chester 14 miles, which was the furthest place of my tedious travel.

For my short stay at Chester, which was but one day and two nights, I had good and friendly entertainment of many gentlemen, to whom I must rest thankful, especially to the worshipful Master Alderman Edwards, and to Master Wright and his wife. It was my fortune to see and rejoice at the sight of the Noble Right Honourable Earl and Knight of the Renowned Order of Saint George, William, Earl of Derby ; and although I have no relation to his lordship or acquaintance with him, yet for the reverend respect which I do owe and bear to nobility, it did me good to see so grave and honourable a peer.

'The city of Chester is of ancient erection and fame, it was the Royal Seat of Kings, and there are yet some ruins left of the memorable Palace of King Edgar, to which mansion the said King was rowed in a barge by eight captives, or tributary kings from Saint Johns, on the river of Dee, which river there is spoiled and impeached 


\section{EARLY PROSE AND POETICAL WOKS.}

by a bank of stones all over it, only for the employment of a mill or two, which river other ways would be both passable and profitable to the whole country for many miles, for the carriage of goods in boats and barques. Chester itself is a fair city four square, well walled, with an old ruined castle which bad been a strong fabric, but now a gaol, the streets are spacious, the buildings sumptuous and so contrived that four or five men may walk in the most parts of a breast, dry from the injury of rain or any falling weather; it is gravely and peaceably governed by a mayor and his twelve brethren, it hath four gates and three posterns, goodly churches, and chiefly painful and learned preachers. And so much for Chester.

Only a merry tale, of a late true business which happened there. There dwelt a bricklayer, a good workman, but a good husband, whose name was John Tilly, who had the good hap to spend all that he got in his lifetime, except two sons and one daughter; and being sick and in his death-bed, there came a poor neighbour to visit him, whom he desired to make or write his last will and testament. The poor man, having ink and paper, asked him what he should write?

Quoth honest John Tittle, my estate is but little, but I pray thee write thus:

IMPRIMIs, I give and bequeath to my wife, for her solace and comfort, my little dog, for it is a pretty nimble active cur, and will make her some sport that may delight her, and put the grief of my death out of her sad remembrance.

Item, I give and bequeath to my eldest son John, all my working tools belonging to my trade of bricklaying, which as he may use, may be as available to him as they have been to me, and this is the surn of my Will.

His youngest son standing by, said, father have you nothing to give me? Yes son, quoth he, I had almost forgotten thee, but I will leave thee somewhat.

Item, I give and bequeath to my son George seven foot of ground under the gallows.

Good father take comfort, said George, for my hope is that you will recover, and live to enjoy that legacy yourself. 
Then the daughter prayed him to give her somewhat whereby she might remember his fatherly love; yes, quoth he, I pray write.

Item, I give and bequeath to my only daughter a whore's conditions and qualities, which as she may use them, she may live in such estate and fame that she may be mistaken for a gentlewoman.

Lastly, I do make and ordain my neighbour here, my full executor; and for his pains for writing my Will, I do give him and his heiress male for ever, an old shoeinghorn.

The ninth of September I turned my back upon Chester, almost without taking leave, and rode fifteen miles to Nantwick, the tenth I rode to Stone and to Lichfield, thirty-two miles.

Of the ancient town of Lichfield I can say nothing, by reason of my short stay; only there is a fair and curious old cathedral church or minster.

And the town hath that privilege, as mine host told me, that they can draw and hang one another, and never trouble any other judge, assize or sessions.

The eleventh I rode to Fazeley, Abersom, Hinckley and Dadlington, eighteen miles, where all weary and almost worn out with age and travel, I rested until Saturday the fourteenth of September, and then rode eight miles to my brother Miles, at my old welcome lodging at Leicester.

\section{News from Hell, with a short description of the Hell at Westminster.}

NoT from that hell where souls tormented lie In endless death, and yet shall never die, Where gnashing cold, commixed with flames still burning, Where's entrance free, but never back returning;

Where nought but horror, fiends, and torments dwell,I bring no news from that accursed Hell. Yet mine own merits are of such low price, To bar me from Celestial Paradise, And sink me in that horrid lake infernal, But that my hope and faith is fix'd supernal. 


\section{EARLY PROSE AND POETICAL WORKS.}

The hell I write of is well known to be A place of pleasure, and for all men free; Where wretched ghosts are not in torments staid, For all the pains upon the purse is laid. 'To find this hell you need not travel far, "Tis understood the high Exchequer bar At Westminster, and those who thither venture, Do not give Cerberus a sop to enter; For Charon's fury, you need never fear it, Although ten thousand do land somewhat near it. Within this bell is good content and quiet, Good entertainment, various sorts of diet, Tables a score at once, in sundry places, Where hungry mouths fall to, and say short graces; And then, in some sort, I may parallel This earthly hell with the infernal Hell. Hot swelt'ring vapours, pots, and cauldrons boiling, Great vehement fires, with roasting, stewing, broiling; The cooks and scullions, all besmear'd and smok'd, And in their master's grease well stew'd and soak'd, And had the devil a stomach unto it, The cook himself is not the rawest bit. Like as th' infernal hell doth entertain All comers, so this hell doth not refrain To give firee welcome unto every oneIf money fail not, there s excepted none. This hell is govern'd by a worthy duke, That Pluto-like, his under fiends rebuke; 'There the tormenting tapster is controll'd, If courteously he nick not, as he should; He must attend at every knock and rap, His reverend jug deck'd with a frothy cap, He fills and empts, and empts and fills again. Like Sisyphus, he toils, but not so vain, Like Danaus' daughters, taking up, and spilling, He's always emptying, and he's never filling. Thither the counsellor for comfort comes To rinse his toiling tongue, and wash his gums. 'The client having 'lityus' empty maw, His guts tormented with the vulture law, 
He coming to this hell may find relief, Of comfortable plum broth and roast beef. There for your solace you may feed upon Whole seas of pottage hot as Phlegethon, And 'midst those seas by art the cooks hath laid Small isles of mutton, which you may invade With stomach, knife and spoon, or tooth and nail, With these, the victory you cannot fail. Therefore this earthly hell is easier far, Then where the miserable damned are; 'There's no redemption from that black abyss, And here regress as well as egress is ;

Therefore they falsely do mistake the story 'To call this hell, which is but purgatory; For here's no thraldom, from this place you may Get present freedom, if the shot you pay.

Here followeth three Satyrical Lashes or Jerks given with the pen of the Author, at or upon the Devil's Arse a Peak.

Pens are most dangerous tools, more sharp by odds 'Than swords, and cut more keen than whips or rods;

Therefore, most high and mighty Duke of Dis,

Commander where the lake Avernus is, Great lord of Limbo, Styx, and Phlegethon,

Of 'Tartarus, Gehenna, Ächeron,

Most potent monarch of black Erebus,

Prince of the triple-headed Cerberus, Sole Emperor of darkness and dark works, Master heretics, infidels, and 'Turks, Arch-flamine of hot 'Tophet's smouldering flames, King of Cocytus and th' infernal streams, Earl of errors, and chief dominator Of all sins done by earth, air, land, or water, Viscount and baron of large Barathrum, Since I have lived to come so near your bum As is your wicked worship's Arse a Peake, 'Though some men think my muse is all too weak; I with my pen do mean to yerk and ferk ye, And, as I promis'd, with three jerks will jerk ye. I know that many fools will jeer and frump, 


\section{EARLY PROSE AND POETICAL WORKS.}

That I durst come so near the devil's rump,

And lash with my poor pen satyrical,

This great Don Diego Diabolical.

But I would have him and his friends to know,

I jeer him not for all his bugbear show :

'Tis known that he and all that him attend,

To any poet never was a friend;

And therefore now I daring him oppose,

And jerk his hellish majesty in prose.

Although you, great master of the hot-house, Don sel de Lucifer, have on the earth in all places and countries many multitudes of damnable sons, friends, and servants, to oppose me and take your part, yet I being come so near your podex, must jerk .your breech with my satyre pendragonly goose quill. You know that reproof is as ill taken as correction by the ungracious; therefore although you are so bad that you are quite past any mending, yet your graceless majesty may be lawfully touched by reprehending. You have been a cheater ever since the creation, and in that art of cozening, you first cheated yourself of everlasting happiness, and gained thereby perpetual perdition, and ever since you have played hocus pocus, and with your tricks, sleights, and juggling legerdemain, done your best to. draw all the whole race of mankind after you into your kingdom of Cimerian tenebrosity; you taught our first parents infidelity, pride, disobedience, and lying, which qualities of theirs are so naturally descended to us that, by your industrious instigation, we do continually show, by our lives and conversations, of what house we came. By their example of believing too much in you, we are grown incredulous in things which most concerns our better and best of being, and we are so inured and practised in lying, by your inspiration being the father of lies, that we are doubtful to believe one another. And yet, like the Cretans, with long use and custom we do many times believe our own lies to be true.

May it please your infernal hell-hood to take into your execrable consideration, that you were the first inventor of the most ignoble science of offence, you taught 
Cain the imbrocado, and showed him how to murder his brother, and from that time to this the art of murdering, killing, and cutting throats, hath been universally and perfectly learned and practised. You have been the inventor of all manner of destroying weapons, from the high degree of the Welsh hook to the lower descent of the tailor's bodkin; and in these later times you, with the help of a Friar, have devised a burning, smouldering, most hellish and undefencible mischief that murders men by heaps, and with a powder, can blow whole kingdoms into the firmament; and for the innumerable engines that are daily used and cast for such uses, your most high and imperial malediction have declared yourself an excellent artist, from the double cannon to the elder gun-mines, counter-mines, petards, granadoes, fireworks, wild-fire, and the devil and all do continually seek and work the destruction of miserable mankind. You are a great traveller, and will take the pains to compass the whole earth to find just man, on purpose to do him mischief, but for a crew of common drunkards, rascals, bawds, and whores, you know you need not wet your foot to seek them, they are your own already, and by your good will, you would fill hell so full that heaven should have but a few.

\section{And so let that pass for one and the First Jerk.}

Secondly, you know that there is but one narrow way to happiness, and many ways to your Zona Torrida, Frigida, for all those large ways do meet in one at the last, and bring poor souls into your pestiferous purse net. Some go by the way of Sodom, to find out.your most damnable mansion; some by the way of incest, some by adultery, some by fornication, for they say you are the master of the honourable and worshipful company and brotherhood of the fornicators, in which regard you are a great friend to parators and panders. You shewed Cham the way how to deride his father, by which example a company of Chammists, have ever since practised not only to mock, scoff, and abuse their natural parents, but also to contemn, rail and revile against kings and princes, who are the royal fathers of terrestrial government, and further 


\section{EARLY PROSE AND POETICAL WORKS.}

to despise, slight, and libel against the most reverend fathers, the stewards and painful dispensers of the spiritual food of eternity; you directed Corah and his complices the high road-way to murmur; Aphithophel to give wicked counsel, and Absalom to rebel and usurp; you shewed Jacob the way to treachery, Achan to steal, Job's wife to abuse her husband, from whom the most part of women, like apt scholars, are very expert in that kind of miserable mystery. You put Gehazi into the highway of taking a bribe, and it is too well known what a wicked number of followers he hath had of all degrees, from the sceptre to the swain, from the black gown to the buckram bag. You directed Nabal, who anagrammatized or read backward is Laban, to be as churlish as a hog, from whom miserable Dives hath perfectly learned the way to true misery; you taught Nimrod the way to tyrannize and enclose and encroach upon land and territories, which hath been the bounding, mounding, and curtailing of commons. The raising of ambition, pride, voluptuousness, and such earthly virtues of accursed greatness, and to the Almighty making of beggars. You tie fast the rich man's purse, and let loose the poor man's curse; you instructed Pharaoh, Senacherib, and Rabshakeh in the way of blasphemy, and from those hellish presidents, their wickedness is daily impiously imitated; Shimei was one of your anathema profound scholars, and from you he learned to curse the Lord's anointed extempore. Once, as I have read, you were so addicted to peace and unity that you made Herod and Pilate friends, who were hateful enemies; but afterwards your hypocrisy was found, that it was your plot to destroy innocence; you made Demas to forsake the truth, and embrace the world, your wicked sister; you have never been unprovided of a kennel of whores, queans, and concubines, to tempt and draw the wisest men to folly; and for him that is most strong in his own opinion, you have always one darling sin or other to fit his disposition, constitution, inclination, or humour, that like a Daliah shall weaken him or quite overthrow him.

And this will suffice for the second Jerk. 
Thirdly and lastly, you know that your end draws nigh, and therefore now you rave, rage, and are more mad than ever you were; you know that after doomsday that you shall have no more power over mortals, then you shall be for ever chained in your den like a dog in a kennel, and therefore now you with all double diligence, do endeavour to do your best to do your worst, and as much as in you lieth, you draw us from bad to worse and from worse to worse. The hypocrite, by your enticement, doth vizard all his villany with the mask or veil of virtue, he follows the steps of Ananias and Saphira to a hair, he with his sour look shrouds a lofty mind. You have scattered pride into as many shapes as Proteus, so that a proud fashion hunter, if either money or credit will furnish him, will transform himself into as many forms as you can do; our roarers, who by your pestiferous favour are styled the damned crew, are so given to most unhallowed meditations that they lie a bed almost till dinner time, to study new oaths, to vent at this ordinary, at bowls, cock-fighting, horse-race, whore-house, or any other place of gentleman-like or noble exercise, and as you have taught them to swear without fear, so they do often forswear without shame, although sometimes they hazard their ears as they do their souls. You set bad projectors and unprofitable a work, as thick as crab-lice or caterpillars, and it is no doubt but you will deal so justly with them, that you will pay them their wages, and after you have set them agog, with a vengeance, to do injury with a mischief. You are so skilful in physic, that you have made too many believe that the.loss of a maiden-head is an approved and speedy medicine for the green sickness. Poets, painters, and some few courtiers, you have so well taught that they can flatter most artificially with pen, picture, and by word of mouth.

It is long of you that whatever the choplin and the chaplain hath, yet the thin-cheek'd chiplin hath nothing at all. I know a poor curate that comes and goes a mile every Sunday, be it winter or summer, all manner of weathers, sometimes wet to the skin, and preaches once a week, on Sundays, for bare five pound a year, the 


\section{EARLY PROSE AND POETICAL WORKS.}

tithe being valued at sixty pounds per annum, so that the miserable stipend or hireling wages will hardly buy wood to make a fire for him when he comes home to dry him, when he is through wet. This is your work, Monsieur Diabola, for it is your inspiration to put such wrangling spirits into impropriators, that for the not paying off a tenth pudding or a tithe egg the law must take his course. You have brought the schismatical separatist to be as uncomfortable as yourself, for, like you, they cannot bide the cross or the sign of it, if it be not upon money; and you have made them as unmannerly as yourself, for they will not move a hat, or bow a knee at the name of our Saviour; and they are waxed as slovenly as you can make them, for they hate clean linen, and all order, neatness and decency in the church. And you have long practised a politic slight, which is, that when a reverend pastor is painfully and carefully preaching to his audience, instructing them how to avoid your snares and traps; then you are so angry and impatient when you are told of your faults, and hear your damnable devices laid open, that you could afford to pull the preacher out of the pulpit by the ears, or to tear him in pieces, but that he is so happy that you have no power over him. Your inveterate malice being limited, curb'd, and snaffled by an unresistable high and omnipotent power, and he very well understands and knows in whose service he is, and whose embassage he delivers, and therefore is so valiant that he neither fears or cares a rush for you; which your imperial malevolence perceiving, you have another trick for him, which is to lull the people asleep, of which number many times the best of the parish are some, by which means you do debar them of what they should hear, and in the mean time the preacher speaks to the bare walls. And I am persuaded that is against your will, that there is any good preacher living, and seeing they do live, in despite of you, and that by their care and industry they do now and then violently pluck a soul from you, in revenge thereof you chiefly seek their confusion, either by war, slander, or starving through want of 'means. Yet this much may be spoken as one of your good parts, 
which is, that you were never known to be drunk; and though you never walk uprightly, yet you never stumbled; you were never so fox'd but you knew the way home; and the truth is, you are so bold that you would make every place your home, the court, the city, the country, the palace, the castle, the cottage, and the church and all, you are so audacious either to enter them by force, or else to insinuate and sneak into them by craft and subtilty. And though you are no drunkard, yet you do love the whole rabble of them so well, that you are unwilling to lose one of them all, but my hope is better. For if they leave it and mend their manners as they should do, the devil the one of them you are like to have. You have the art to make great scholar to learn retrograde, for if a man be never so good a grammarian, and hath Greek and Latin as perfect. as Homer or Virgil, yet, if he be married, you do too often teach his wife the way to read him backward, like an Hebrician, and though he be never so well skilled in learned volumes and the seven liberal arts, yet she puts him again into his horn-book. You have so much devotion in you that you do assist those brethren that do pray zealously, that they may be disobedient with a safe conscience, and you make them so stout and valiant that some of them are more able to do more service in a white sheet than the honestest man in the whole shire can do. You know that the projector would be an honest man if he did not keep company with himself, therefore you might do somewhat to be talked of, if you would separate him. It is a scurvy fashion of your devising that wise men in russet, must reverence and stand bare to silken fools; but to conclude, you have gotten such a freedom that you have a finger in all trades, and an oar in every man's boat, nor was there ever any bad thought, word or deed, imagined, spoken, or committed since the Creation, but you were at the middle and both ends of it; and I do remember that I have read how once you bragged, boasted and promised to give all the kingdoms of the world to be worshipped, and afterwards you were in that poor roguish case, that you were fain to ask leave to take possession of a silly hog. In which manner 


\section{EARLY PROSE AND POETICAL WORKS.}

of vain-glorious ostentation, bragging and boasting, the most part of men are expert, and to promise much and to perform nothing, is so easy a lesson of your teaching that many great men are more ready and perfect in it than in their pater noster. And now you grand master of mischief, you may truss up your hose, for at this time my pen is worn blunt, my inkhorn dry, and myself weary with jerking, where correction is in pain, and no possibility of no amendment.

Thus after the expense of much money, and ten weeks time, having ridden 645 miles, of sundry measures and sizes, all weary and almost moneyless, I returned to London on Friday, the twentieth of September, 1639. 


\title{
M A D F A S I O N S
}

\section{ODD FASHIONS}

\section{ALL OUT OF FASHIONS}

OR

\author{
THE EMBLEMS OF THESE \\ DISTRACTED TIMES
}

[On the title page of the original of this, there is a rude woodcut, which is not here reproduced.] 

MAD FASHIONS, ODD FASHIONS, ETC. 313

\section{MAD FASHIONS, ODD FȦSHIONS, ALL OUT OF FASHIONS,}

OR

\section{THE EMBLEMS OF THESE DISTRACTED TIMES.}

THE picture that is printed in the front

Is like this kingdom, if you look upon't;

For if you well do note it as it is,

It is a transform'd metamorphosis.

This monstrous picture plainly doth declare

This land, quite out of order, out of square;

His breeches on his shoulders do appear,

His doublet on his lower parts doth wear;

His boots and spurs upon his arms and hands,

His gloves upon his feet, whereon he stands;

The church o'erturned, a lamentable show,

The candlestick above, the light below;

The coney hunts the dog, the rat the cat,

The horse doth whip the cart, I pray mark that,

The wheelbarrow doth drive the man, oh base,

And eels and gudgeons fly a mighty pace.

And sure this is a monster of strange fashion,

That doth surpass all Ovid's transformation.

And this is England's case this very day,

All things are turned the clean contrary way;

For now, when as a royal parliament,

With king, and peers, and commons whole consent,

Have almost sat two years, with pains and cares, And charge, to free us from our griefs and fears;

For when many a worthy lord and knight, And good esquire, for king and country's right, Have spent so much time with great toil and heed, All England's vicious garden how to weed;

So like a wilderness 'twas overrun,

That though much hath been done, all is not done.

The devil doth persuade, entice and lurk,

And force bad men to set good men awork.

That whilst the worthies strive to right our wrongs, 


\section{EARLY PROSE AND POETICAL WORKS.}

And give to each man what to him belongs;

Whilst they take pains to settle all things here, An Irish devil doth madly domineer.

From hell's black pit, begirt with Romish arms, Thousands of locusts are in troops and swarms, More barbarous than the heathen, worse than Jews, No Turks or Tartars would such tortures use. Sure that religion can no ways be good, That so inhumanly delights in blood; Nor do that doctrine from the scriptures spring, . That subjects should rebel against their king. Nay, further, murder, ravish, spoil, deflower, Burn and lay waste, depopulate, devour, Not sparing infants at the breast or womb, To die where first they lived, their birth, their tomb. 'Tis said no serpent, adder, snake, or toad, Can live in Ireland, or hath there abode. 'Tis strange that she those vipers doth not kill, That gnaws her bowels, and her blood doth spill. Can Irish earth kill all things venomous, And can she nurse such vermin mischievous; Her own sons native, worse than strangers born, They have their mother's entrails rent and torn; Yet still her indulgency harbours those, And feeds those rebels that do breed her woes. God, in Thy mercy, give her strength and aid, And courage, make her foes and ours dismayed; Thou Lord of Hosts, thine own cause take in hand, Thy foes, Thine Anti-Christian foes, withstand. Defend Thy truth, and all our armies guide, Our enemies to scatter and divide. Thus leaving Ireland, with my hearty prayers, To Britain back again my muse repairs ; Where I perceive a metamorphosis, Is most preposterous, as the picture is, The world's turned upside down, from bad to worse, Quite out of frame, the cart before the horse. The felt-maker, and saucy stable groom, Will dare to perch into the preacher's room, Each ignorant, do of the Spirit boast, 
And prating fools brag of the Holy Ghost, When ignoramus will his teacher teach, And sow-gelders and cobblers dare to preach; This shews, men's wits are monstrously disguised, Or that country is antipodis'd.

When holy common prayer, is by the rabble Accounted porridge, and unfruitful babble, When our belief is not so much as said,

When as the Ten Commandments are not read, When as the Lord's Prayer is almost neglected, When as all decency is quite rejected, When to avoid a Romish Papist's name, A man must be unmannerly, past shame, When he that show reverence doth offend, And he seems best that will not bow or bend, When he that into God's bouse doth not come, As to a stable or a tippling room, Is counted for a Popish favourite, And branded so, despised, and scorned with spite. When he that, of his ways, doth conscience make, And in his heart doth world, flesh, fiend, forsake, Loves God with all his soul, adores no pelf, And loves his neighbour as he loves himself; This man is rare to find, yet this rare man Shall have the hateful name of Puritan ; When execrations pierce the firmament, And oaths do batter against Heaven's battlement. When imprecations and damned blasphemies, In sundry cursed volleys scale the skies,

When men more brutish than the horse or mule,

Who not to obey, presume to rule, Thus church and common-wealth, and men, all are Much like the picture, out of frame or square. And if 'twere possible our fathers old Should live again, and tread upon this mould, And see all things confused, overthrown, They would not know this country for their own. For England hath no likelihood or show, Of what it was but seventy years ago ; Religion, manners, life and shapes of men, 


\section{EARLY PROSE AND POETICAL WORKS.}

Are much unlike the people that were then, Nay England's face and language is estrang'd, That all is metamorphosed, chopped, and changed ;

For like as on the poles, the world is whirled, So is this land the bedlam of the world;

That I amazed and amated am, To see Great Britain turned to Amsterdam, Men's brains and wits, two simples beat together, From thence, mixed and compounded, are sent hither For Amstertam is landed, as I hear,

At Rye or Hastings, or at Dover pier,

At Harwich, Ipswich, Sandwich, or at Weymouth, At Portsmouth, Dartmouth, Exmouth, Plymouth, Falmouth,

At Yarmouth, and at all the ports to Teignmouth, And westward unto Bristol and to Monmouth; From all these mouths and more, mad sects are sent, Who have religion all in pieces rent.

One would have this, another would have that, And most of them would have they know not what. God give us peace, and ease us in our pain, And send those sects from whence they came again, The Papist and the Schismatic ; both grieves The church, for she's like Christ, between two thieves.

I took the protestation twice of late,

When I protested not to innovate.

T'avoid all Popish rites, and to express

Obedience to what England's Church profess, My loyalty unto my King is bent

With duty to the Peers and Parliament.

With prayers, and my best service for them all,

That on them may Heaven's chiefest blessings fall,

That with one heart, as one man with one mind,

For God's great glory, they may be combined,

And never vary, but go boldly on,

To end the good work, which they have begun.

This is the sum, which ne'er shall be forsook,

Of what $I$ in the protestation took.

But, for all this, I may be mannerly

In God's house, and be free from Papistry; 


\section{AEESE LIBRATY
ONIVETHESITY
CALIFEIENAN}

MAD FASHIONS, ODD FASHIONS, ETC.

I hope I may put off my hat, and be Allowed to kneel, and pray, and bow my knee, When as divine command bids, only then I'll bow to God, and not to saints or men. And from those duties I will never vary, Till death or order do command contrary. The Almighty's name be ever praised and blessed, That Romish superstition is suppressed. We have no abbeys, abbots, friars, or monks, Nor have we nuns, or stews allowed for punks, We have no masses, or no mass-priests here; But some are hanged, and some are fled for fear. All those that are so bold to stay behind, I wish they may like entertainment find; Beads, baubles, relics, tapers, lamps or lights, We have no superstitious Romish rites, We seek our pardons from our Heavenly Hope, And not by works or favour from the Pope. To saints we make no prayer or intercession, And unto God alone we make confession. We hold no real presence in the bread, And we do know King Charles our supreme head, Beneath God, who hath placed him in his throne, For other supreme we acknowledge none. No purgatory, image, wood or stone, No stock or carved block we trust upon, Nor is our Church discretion here so little, As to baptize with cream, with salt and spittle. We have as many sacraments as Heaven Ordained; which are but two, and Rome hath seven. We do not christen bells, and give them names Of Simon, Peter, Andrew, John, and James; We use no pilgrimage or holy water, Nor in an unknown tongue our prayers scatter. All these and many more in Rome are used, . Which are by us rejected and refused; And yet too many faults, alas remains, Which are the Church's and the kingdom's stains. The Church triumphant is not clear from spots, The poor Church militant hath still somę blots; 


\section{EARLY PROSE AND POETICAL WORKS.}

Here's all imperfect, something's still amiss, And nothing's blessed but in eternal bliss. Meantime, till we amend and leave our crimes, The picture is the emblem of the times.

THE END. 


\section{NEW BO0KS AND NEW EDITIONS.}

\section{ANGLING REMINISCENCES OF THE RIVERS}

AND LOCHS OF SCOTLAND. By Thomas Tod Stoddart. Post 8vo. Price 3s. 6d.

If not the most useful, this is at least the most interesting of all Stoddart's angling works, of which there are three in num. ber. The above is not to be confounded with "The Scottish Angler" on the one hand, or "The Angler's Companion" on the other, though from the same pen. The present work is colloquial throughout, and teeming with the richest humour from beginning to end.

\section{THE WHOLE FAMILIAR COLLOQUIES OF ERASMUS. Translated by Nathan Bailey. Demy 8vo. Price 4s. 6d.}

A complete and inexpensive edition of the great book of amusement of the sixteenth century. Probably no other work so truly and intensely depicts the life and notions of our forefathers 350 years ago, as does this inimical production of the great Erasmus.

T'here are 62 dialogues in all, and an immense variety of subjects are dealt with, such as "Benefice-Hunting," "The Soldier and the Carthusian," "The Franciscans," "The Apparition," "The Beggar's Dialogue," "The Religious Pilgrimage," "The Sermon," "The Parliament of Women," etc., etc. The whole work is richly characteristic, and is full of the richest humour and satire.

THE COURT OF SESSION GARLAND. Edited by James Maidment, Advocate. New edition, including all the Supplements. Demy 8vo. Price 7s. 6d.

$A$ collection of most interesting anecdotes and facetiae con. nected with the Court of Session. Even to those not initiated in the mysteries of legal procedure, much of the volume will be found highly attractive, for no genuine votary of Momus can be insensible to the fun of the Justiciary Opera, as illustrated by the drollery of the "Diamond Beetle Case," and many others of an amusing nature, such as " The Poor Client's Complaint," "The Parody on Hellvellyn," "The King's Speech," "Lord Bannatyne's Lion," "The Beauties of Overgroggy," etc., etc. 


\section{ST. KILDA AND THE ST. KILDIANS. By RoBerT} Connell. Crown 8vo. Price 2s. 6d.

"A capital book. It contains everything worth knowing about the famous islet and its people."-'THE BAILIE.

"Interesting and amusing. It includes a lively description of the daily life of the inhabilants, the native industries of fishing, bird catching, and the rearing of sickly sheep and cattle, and gives a vivid picture of the Sabbatarian despctism of the Free Church minister who rules the small population."-SATURDAY Review.

\section{THE PRAISE OF FOLLY. By Erasmos. With} Numerous Illustrations by Holbein. Post 8vo. Price 4s. $6 \mathrm{~d}$.

An English translation of the "Encomium Moriae" which has always held a foremost place among the more popular of the writings of the great scholar. This work is probably the most satirical production of any age. It is intensely humorous throughout, and is entirely unique in character. This edition also contains Holbein's illustrations, attaching to which there is very considerable interest.

HUMOROUS AND AMUSING SCOTCH READINGS. For the Platform, the Social Circle, and the Fireside. By Alexander G. Murdoch. Second Edition. Post 8vo. Price 1s. Paper Covers.

Humorous and amusing Scotch readings, ffteen in number, and illustrative of the social life and character of the Scottish people, than which the author believes no more interesting sub. ject can be found. Among other readings may be mentioned, "Mrs. Macfarlane's Rabbit Dinner," "The Washin'-Hoose Key," “Jock Broon's Patent Umbrella," "Willie Weedrap's Domestic Astronomy," etc., etc.

A NECDOTES OF FISH AND FISHING. Вy Тномas

Booser. Post Evo. Price 3s. 6d.

An interesting collection of anecdotes and incidents connected with fish and fishing, arranged and classified into sections. It deals with all varieties of British fish, their habits, different modes of catching them, interesting incidents in connection with their capture, and an infinite amount of angling gossip relating to each. Considerable space is also devoted to the subject of fishing as practised in different parts of the vorld. 
THE DANCE OF DEATH: Illustrated in Forty-Eight Plates. By John Holbein. Demy 8vo. Price 5s.

$A$ handsome and inexpensive edition of the great Holbein's most popular production. It contains the whole forty-eight plates, with letterpress description of each plate, the plate and the description in each case being on separate pages, facing each other. The first edition was issued in 1530, and since then innumerable impressions liave been issued, but mostly in an expensive form, and unattainable by the general public.

\section{THE LITERARY HISTORY OF GLASGOW. By} W. J. Duncan. Quarto. Price 12s.6d. net. Printed for Subscribers and Private Circulation.

This volume forms one of the volumes issued by the Maitland $C l u b$, and was originally published in 1831 . This edition is a verbatim et literatim reprint, and is limited to 350 copies, with an appendix additional containing extra matter of considerable importance, not in the original work.

The book is chiefly devoted to giving an account of the greatest of Scottish printers, namely, the Foulises, and furnishes a list of the books they printed, as likewise of the sculptures and paintings which they so largely produced.

GOLFIANA MISCELLANEA. Being a Collection of Interesting Monographs on the Royal and Ancient Game of Golf. Edited by James Lindsay Stewart. Post 8vo. Price 4s. 6d.

A collection of interesting productions, prose and verse, on or relating to, the game of golf, by various authors both old and recent. Nothing has been allowed into the collection except works of merit and real interest. Many of the works are now extremely scarce and, in a separate form, command very high prices. It contains twenty-three separate productions of a great variety of character-historical, descriptive; practical, poetical, humorous, biographical, etc.

\section{THE BARDS OF THE BIBLE. By George Gilfillan. Seventh Edition. Post 8vo. Price 5s.}

The most popular of the writings of the late Rev. Dr. Gilfillan. The author, in his preface, states that the object of the book was chiefly a prose poem or hymn in honour of the poetry and the poets of the Bible. It deals with the poetical side of the inspired word, and talies up the separate portions in chronological order. 
ONE HUNDRED ROMANCES OF' REAL LIFE. By Leigh Hunt. Post 8 vo. Price 3s. 6d.

A handsome edition of Leigh Hunt's famous collection of romances of real life, now scarce in a complete form. The present issue is complete, containing as it does the entire hundred as issued by the author. All being incidents from real life, the interest attaching to the volume is not of an ordinary character. The romances relate to all grades of society, and are entirely various in circumstance, each one being separate and distinct in itself.

\section{UNIQUE TRADITIONS CHIEFLY OF THE WEST} $A N D$ SOUTH OF SCOTLAND. By JOHN GordON

Barbour. Post 8vo. Price 4s. 6d.

A collection of interesting local and popular traditions gathered orally by the author in his wanderings over the West and South of Scotland. The author narrates in this volume, thirty-five separate incidental traditions in narrative form, connected with places or individuals, all of a nature to interest the general Scottish reader, such as " The Red Comyn's Castle," "The Coves of Barholm," "The Rafters of Kirk Alloway," "Cumstone Castle," "The Origin of Loch Catrine," etc., etc.

MODERN ANECDOTES: A Treasury of Wise and Witty Sayings of the last Hundred Years. Edited, with Notes, by W. Davenport Adams. Crown 8vo. Price 3s. 6d.

The Anecdotes are all authenticated and are classed into Sections-I. Men of Society. II. Lawyers and the Law. III. Men of Letters. IV. Plays and Players. V. Statesmen and Politicians. VI. The Church and Clergy. VII. People in General.

In compiling a work like this, Mr. Adams has steadily kept in view the necessity of ministering to the requirements of those who will not read anecdotes unless they have reason to know that they are really good. On this principle the entire editorial work has been executed. The book is also a particularly handsome one as regards printing, paper, and binding.

THE LITURGY OF JOHN KNOX: As received by the Church of Scotland in 1564. Crown 8vo. Price 5s.

$A$ beautifully printed edition of the Book of Common Order, more popularly known as the Liturgy of John Knox. This is the only modern edition in which the original quaint spelling is retained. In this and other respects the old style is strictly reproduced, so that the work remains exactly as used by our forefathers three hundred years ago. 
THE GABERLUNZIE'S WALLET. By JAMES

Ballantine. Third edition. Cr. 8vo. Price 2s. 6d.

$A$ most interesting historical tale of the period of the Pretenders, and containing a very large number of favourite songs and ballads, illustrative of the tastes and life of the people at that time. Also contarning numerous facetious illustrations by Alexander A. Ritchie.

THE WOLFE OF BADENOCH. A Historical Romance of the Fourteenth Century. By SIR Thomas Dick LAUDER. Complete unabridged edition. Thick Crown 8vo. Price 6s.

This most interesting romance has been frequently described as equal in interest to any of Sir Walter Scott's historical tales. This is a complete unabridged edition, and is uniform with "Highland Legends" and "Tales of the Highlands," by the same author. As several abridged editions of the work have been published, especial attention is drawn to the fact that the above edition is complete.

'THE LIVES OF' THE PLA YERS. By JoHn Galt, Esq. Post 8vo. Price 5s.

Interesting accounts of the lives of distinguished actors, such as Betterton, Cibber, Farquhar, Garrick, Foote, Macklin, Murphy, Kemble, Siddons, \&c., \&c. After the style of Johnson's "Lives of the Poets."

KAY'S EDINBURGH PORTRAITS. A Series of Anecdotal Biographies, chiefly of Scotchmen. Mostly written by J Esq. Popular Edition. 2 Vols., Post 8vo. Price 12s.

A popular edition of this famous work, which, from its exceedingly high price, has hitherto been out of the reach of the general public. This edition contains all the reading matter that is of general interest; it also contains eighty illustrations.

\section{THE RELIGIOUS ANECDOTES OF SCOTLAND.} Edited by William Adamson, D.D. Thick Post 8vo. Price 5s.

A voluminous collection of purely religious aneclotes relating to Scotland and Scotchmen, and illustrative of the more serious side of the life of the people. The anecdotes are chiefly in connection with distinguished Scottish clergymen and laymen, such as Rutherford, Macleod, Guthrie, Shirra, Leighton, the Erskines, Knox, Beattie, $M^{\prime} C$ 'vie, Eadie, Brown, Irving, Chalmers, Lawson, Milne, M'Cheyne, $\& c$., \&c. The anecdotes are serious and religious purely, and not at all of the ordinary witty description. 
DAYS OF DEER STALKING in the Scottish Highlands, including an account of the Nature and Habits of the Red Deer, a description of the Scottish Forests, and Historical Notes on the earlier Field Sports of Scotland. With Highland Legends, Superstitions, Folk-Lore, and Tales of Poachers and Freebooters. By William Scrope. Illustrated by Sir Edwin and Charles Landseer. Demy 8vo. Price 12s.6d.

"The best book of sporting adventures with which we are acquainted."-АTHEN कUM.

"Of this noble diversion we owe the first satisfactory description to the pen of an English gentleman of high birth and extensive fortune, whose many amiable and elegant personal qualities have been commemorated in the diary of Sir Walter scott."LONDON QUARTERLY REVIEW.

DAYS AND NIGHTS OF SALMON FISHING in the River Tweed. By William Scrope. Illustrated by Sir David Wilkie, Sir Edwin Landseer, Charles Landseer, William Simson, and Edward Cooke. Demy 8vo. Price 12s. 6d.

" $M r$. Scrope's book has done for salmon fishing what its predecessor performed for deer stalking."-LONDON QDARTERLY REVTEW.

"Mr. Scrope conveys to us in an agreeable and lively manner the results of his more than twenty years' experience in our great Border river. . . . The work is enlivened by the narration of numerous angling adventures, which bring out with force and spirit the essential character of the sport in question. . . . Mr. Scrope is a skilful author as well as an experienced angler. It does not fall to the lot of all men to handle with equal dexterity, the brush, the pen, and the rod, to say nothing of the rifle, still less of the leister under cloud of night."-BLAckwood's MAGAzINE.

THE FIELD SPORTS OF THE NORTH OF EUROPE.

A Narrative of Angling, Hunting, and Shooting in Sweden and Norway. By Captain L. Lloyd. New edition. Enlarged and revised. Demy 8vo. Price 9s.

"The chase seems for years to have been his ruling passion, and to have made him a perfect model of perpetual motion. We admire Mr. Lloyd. He is a sportsman far above the common run."-Blackwood's Magazine.

"This is a very entertaining work and written, moreover, in an agreeable and modest spirit. We strongly recommend it as containing much instruction and more amusement. - ATHENAUM. 
PUBLIC AND PRIVATE LIBRARIES OF GLAS$G O W$. A Bibliographical Study. By Thomas Mason. Demy 8vo. Price 12s. 6d. net.

A strictly Bibliographical work dealing with the subject of rare and interesting works, and in that respect describing three of the public and thirteen of the private libraries of Glasgow. All of especial interest.

\section{THE LIFE OF SIR WILLIAM WALLACE. BY} JoHN D. CARrIck. Fourth and cheaper edition. Royal 8vo. Price 2s. 6d.

The best life of the great Scottish hero. Contains much valuable and interesting matter regarding the history of that historically important period.

THE HISTORY OF THE PROVINCE OF MORA $Y$.

By Lachlan Shaw. New and Enlarged Edition, 3 Vols., Demy 8vo. Price 30s.

The Standard History of the old geographical division termed the Province of Moray, comprising the Cownties of Elgin and Nairn, the greater part of the County of Inverness, and a portion of the County of Banff. Cosmo Innes pronounced this to be the best local history of any part of Scotland.

HIGHLAND LEGENDS. By Sir Thomas Dick LaUder. Crown 8vo. Price 6s.

Historical Legends descriptive of Clan and Highland Life and Incident in former times.

TALES OF THE HIGHLANDS. By Sir Thomas Dick LaUdFr. Crown 8vo. Price 6s.

Uniform with and similar in character to the preceding, though entirely different tales. The two are companion volumes.

AN ACCOUNT OF THE GREAT MORAY FLOODS IN 1829. By Sir Thomas Dick Lauder. Demy 8vo., with 64 Plates and Portrait. Fourth Edition. Price 8s. 6d.

A most interesting work, containing numerous etchings by the Author. In addition to the mainfeature of the book, it contains much historical and legendary matter relating to the district. through which the River Spey runs. 
OLD SCOTTISH CUSTOMS: Local and General. By E. J. Guthrie. Crown 8vo. Price 3s. 6d.

Gives an interesting account of old local and general Scottish customs, now rapidly being lost sight of.

\section{A HISTORICAL ACCOUNT OF THE BELIEF IN} WITCHCRAFT IN SCOTLAND. By CharLeS KirkPatrick Sharpe. Crown 8vo. Price 4s. 6d.

Gives a chronological account of Witchcraft incidents in Scotland from the earliest period, in a racy, attractive style. And likewise contains an interesting Bibliography of Scottish books on Witchcraft.

"Sharpe was well qualified to gossip about these topics."SatURday Review.

"Mr. Sharpe has arranged all the striking and inportant phenomena associated with the belief in Apparitions and Witchcraft. An extensive appendix, with a list of books on Witchcraft in Scotland, and a useful index, render this edition of $\mathbf{M r}$. Sharpe's work all the more valuable."-GLASGOw Herald.

TALES OF THE SCOTTISH PEASANTRY. By AleXANDer and JoHn Bethune. With Biography of the Authors by JoHn Ingram, F.S.A.Scot. Post 8vo. Price 3s. 6d.

" It is the perfect propriety of taste, no less than the thorough intimacy with the subjects he treats of, that gives Mr. Bethune's book a great charm in our eyes."-ATHEN \&EM.

"The pictures of rural life and character appear to us re. markably true, as well as pleasing."-ChAMBERs's JotRnAL.

The Tales are quite out of the ordinary routine of such literature, and are universally held in peculiarly high esteem. The following may be given as a specimen of the Contents:- "The Deformed," "The Fate of the Fairest," "The Stranger," "The Drunkard," "The Illegitimate," "The Cousins," \&c., \&c.

\section{A JOURNEY TO THE WESTERN ISLANDS OF} SCOTLAND IN 1773. By Samuel Johnson, LL.D. Crown 8vo. Price 3s.

Written by Johnson himself, and not to be confounded with Boswell's account of the same tour. Jolinson said that some of his best writing is in this work. 
THE HISTORY OF BURKE AND HARE AND OF THE RESURRECTIONIST TIMES. A Fragment from the Criminal Annals of Scotland. By GEORGE Mac Gregor, F.S.A.Scot. With Seven Mllustrations, Demy 8vo. Price 7s. 6d.

"Mr. MacGregor has produced a book which is eminently readable."-JOURNAL OF JURISPRUDENCE."

"The book contains a great deal of curious information.".-. Scotsman.

"He who takes up this book of an evening must be prepared to sup full of horrors, yet the banquet is served with much of literary grace, and garnished with a deftness and taste which render it palatable to a degree."-GLasGow Herald.

THE HISTORY OF GLASGOW: From the Earliest Period to the Present Time. By Georae Mac GreGor, F.S.A.Scot. Containing 36 Illustrations. Demy 8vo. Price 12s. 6d.

An entirely new as well as the fullest and most complete his. tory of this prosperous city. In addition it is the first written in chronological order. Comprising a large handsome volume. in Sixty Chapters, and extensive Appendix and Index, and illustrated throughout with many interesting engravings and, drawings.

\section{THE COLLECTED WRITINGS OF DOUGAL} GRAHAM, "Skellat," Bellman of Glasgow. Edited with Notes, together with a Biographical and Bibliographical-Introduction, and a Sketch of the Chap Iiterature of Scotland, by GeORGe MAC Gregor, F.S.A.Scot. Impression limited to 250 copies. 2 Vols., Demy 8vo. Price 21s.

With very trifling exceptions Graham was the only writer of purely Scottish chap-books of a secular description, almost all the others circulated being reprints of English productions. His writings are exceedingly facetious and highly illustrative of the social life of the period.

SCOTTISH PROVERBS. By ANDREW Henderson. Crown 8vo. Cheaper edition. Price 2s. 6d.

A cheap edition of a book that has long held a high place in Scottish Literature. 
THE BOOK OF SCOTTISH ANECDOTE: Humorous, Social, Legendary, and Historical. Edited by Alexander Hislop. Crown 8vo., pp. 768. Cheaper edition. "Price $5 \mathrm{~s}$.

The most comprehensive collection of Scottish Anecdotes, containing about 3,000 in number.

THE BOOK OF SCOTTISH STORY: Historical, Traditional, Legendary, Imaginative, and Humorous. Crown 8vo., pp. 768. Cheaper edition. Price 5s.

A most interesting and varied collection by Leading Scottish Authors.

THE BOOK OF SCOTTISH POEMS: Ancient and Modern. Edited by J. Ross. Crown 8vo., pp. 768. Cheaper edition. Price 5s.

Comprising a History of Scottish Poetry and Poets from the earliest times. With lives of the Poets and Selections from their Writings.

$$
\text { ** These three works are uniform. }
$$

A DESCRIPTION OF THE WESTERN ISLES OF SCOTLAND, CALLED HYBRIDES. With the Genealogies of the Chief Clans of the Isles. By SIr Donalo Monro, High Dean of the Isles, who travelled through most of them in the year 1549. Impression limited to 250 copies. Demy 8 vo. Price $5 \mathrm{~s}$.

This is the earliest written description of the Western Islands, and is exceedingly quaint and interesting. In this edition all the old curious spellings are strictly retained.

A DESCRIPTION OF THE WESTERN ISLANDS OF SCOTLA ND CIRCA 1695. By Martin Martin. Impression limited to 250 copies. Demy 8vo. Price 12s. $6 \mathrm{~d}$.

With the exception of Dean Monro's smaller work 150 years previous, it is the earliest description of the Western Islands we have, and is the only lengthy work on the subject before the era of modern innovations. Martin very interestingly describes the people and their ways as he found them about 200 years ago. 
THE SCOTTISH POETS, RECENT AND LIVING. By Alexander G. Mordoch. With Portraits, Post 8vo. Price 6s.

A most interesting resume of Scottish Poetry in recent times. Contains a biographical sketch, choice pieces, and portraits of the recent and living Scottish Poets.

THE HUMOROUS CHAP-BOOKS OF SCOTLAND. By John Fraser. 2 Vols., Thin Crown 8vo (all published). Price $5 \mathrm{~s}$.

An interesting and racy description of the chap-book literature of Scotland, and biograplical sketches of the writers.

THE HISTOR Y OF STIRLINGSHIRE. By WILLIAM

Nimmo. 2 Vols., Demy 8vo. 3rd Edition. Price 25s.

$A$ new edition of this standard county history, handsomely printed, and with detailed map giving the parish boundaries and other matters of interest.

This county has been termed the battlefield of Scotland, and in addition to the many and important military engagements that have taken place in this district, of all which a full account is given,-this part of Scotland is of especial moment in many other notable respects, - among which particular reference may be made to the Roman Wall, the greater part of this most interesting object being situated within the boundaries of the county.

A POPULAR SKETCH OF THE HISTORY OF GLA SGO W: From the Earliest Period to the Present Time. By Andrew Wallace. Crown 8vo. Price 3s.6d.

The only attempt to write a History of Glasgow suitable for popular use.

THE HISTORY OF THE WESTERN HIGHLANDS AND ISLES OF SCOTLAND, from A.D. 1493 to A.D. 1625. With a brief introductory sketch from A.D. 80 to A.D. 14c3. By Donald Gregory. Demy 8vo. Price 12s. $6 \mathrm{~d}$.

Incomparably the best history of the Scottish Highlands, and written purely from original investigation. Also contains parti. cularly full and lengthened Contents and Index, respectively at beginning and end of the volume. 
THE history of a YRSHIRE. By James Paterson.

5 Vols., Crown 8vo. Price 28s. net.

The most recent and the fullest history of this exceedingly interesting county. The work is particularly rich in the de. partment of Family History.

MARTYRLAND: a Historical Tale of the Covenanters.

By the Rev. Robert Simpson, D.D. Crown 8vo.

Cheaper Edition. Price 2s. 6d.

A tale illustrative of the history of the Covenanters in the South of Scotland.

TALES OF THE COVENANTERS. By E. J. GUThrie. Crown 8vo. Cheaper Edition. Price 2s. $6 \mathrm{~d}$.

A number of tales illustrative of leading incidents and char. acters connected with the Covenanters.

PERSONAL AND FAMILY NAMES. A Popular Monograph on the Origin and History of the Nomenclature of the Present and Former Times. By HARRY Alfred Long. Demy 8vo. Price 5s.

Interesting investigations as to the origin, history, and meaning of about 9,000 personal and family names.

THE SCOTTISH GALLOVIDIAN ENCYCLOP AEDIA of the Original, Antiquated, and Natural Curiosities of the South of Scotland. By JоHN MACTAGgart. Demy 8vo. Price raised to 25s. Impression limited to 250 copies.

Contains a large amount of extremely interesting and curious matter relating to the South of Scotland.

THE COMPLETE TALES OF THE ETTRICK SHEPHERD (JAMES HOGG). 2 vols., Demy 8 vo.

An entirely new and complete edition of the tales of this popular Scottish writer.

GLASGOW : THOMAS D. MORISON.

LONDON : HAMILTON, ADAMS \& CO.

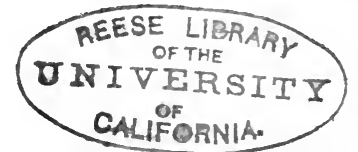




$\begin{array}{lll}1 & 1\end{array}$

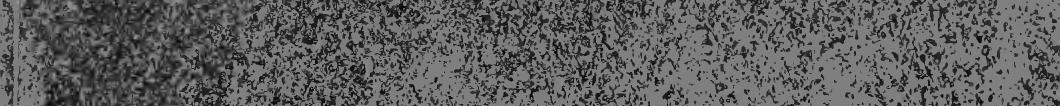

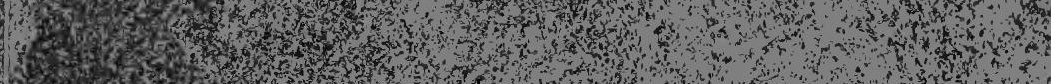

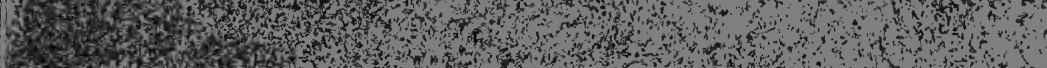

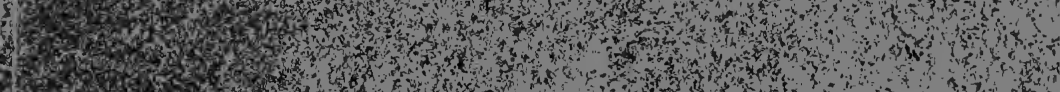

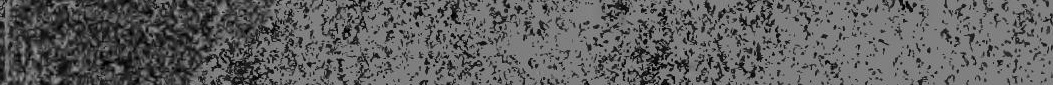

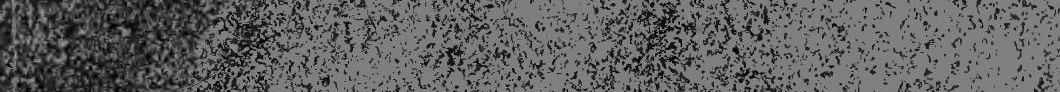

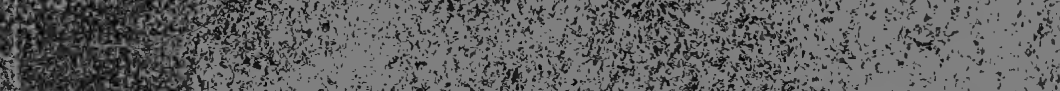

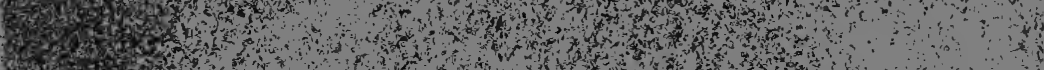
15. 30 . 1.

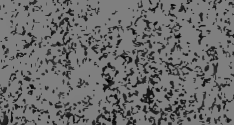

Sor

3.

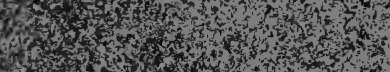

7.

1.

Win

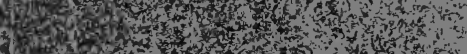

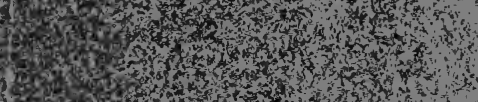

W.

(⿻)丨子

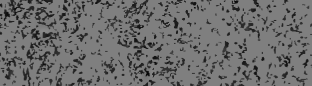

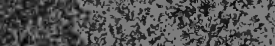

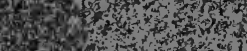

M 1000

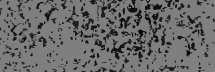

ton

and

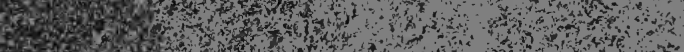

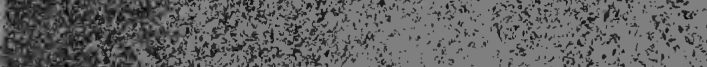

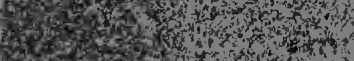

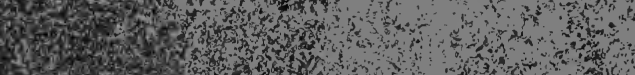

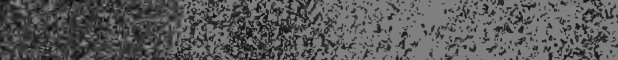

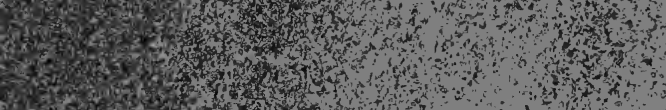

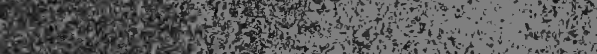

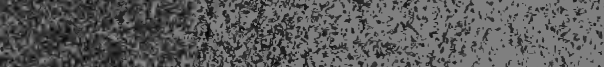

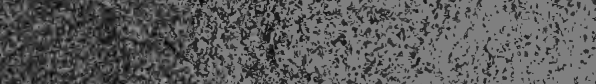

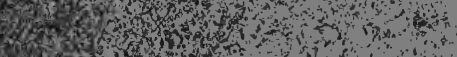

$54 x_{0}+a_{0}$

(1) 
Renewed books are subject to immediate recall.

3OAproIRH

NN STALKS PECD D

Tharr-PS

AUG 151962

MrR-3

ojog

$7: 0$

III fo lith

3. hU. $62 E F$

$F=-D L D$

NIA

frAugles

MAR 9 '65-4PM

21-100m-1,'54 (1887s16) 476

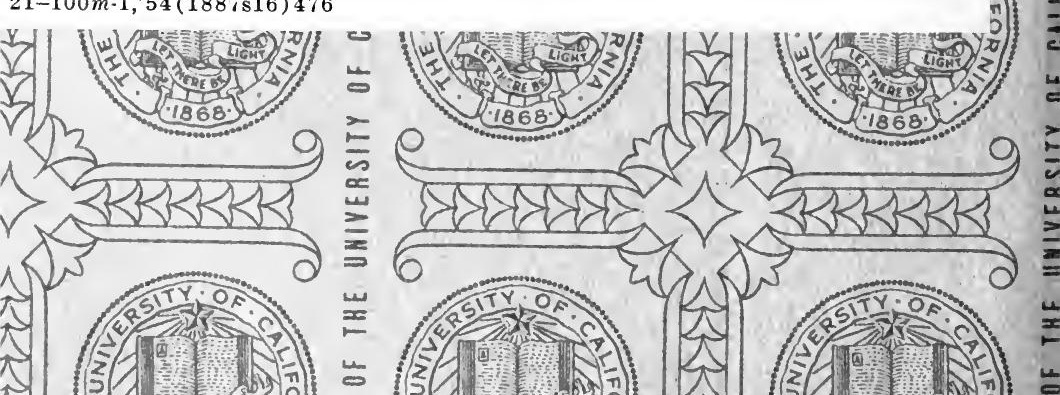


